Florida International University FIU Digital Commons

4-1-2003

\title{
Design of an adequate women's asylum : analysis and architectonic proposal for a home for women with children in need
}

Carmelina Alvarez-Giboyeaux

Florida International University

DOI: $10.25148 /$ etd.FI14032301

Follow this and additional works at: https://digitalcommons.fiu.edu/etd

Part of the Architecture Commons

\section{Recommended Citation}

Alvarez-Giboyeaux, Carmelina, "Design of an adequate women's asylum : analysis and architectonic proposal for a home for women with children in need" (2003). FIU Electronic Theses and Dissertations. 1344.

https://digitalcommons.fiu.edu/etd/1344 
(C) Copyright 2004 gy CARMElina Álvarez-Gibgyeaux ALL RIGHTS RESERVED. 


\section{DEDICATION}

THIS THESIS IS DEDICATED TO MY MOTHER, WHO WILL ALWAYS BE MY SOURCE DF INSPIRATION, FOR HER UNDERSTANDING AND UNCONDITIONAL LOVE, TO MY NIECES fransheska and valeria Álvarez, who lodk at me as a model for their FUTURE, TD MY BRDTHERS AND SISTERS, WHD ARE ALSD MY FRIENDS, AND TO MY FRIEND CATERINA SERGIDU, WHO HELPED ME WHEN I NEEDED HER. AND THE DEEPEST THANKS TO LUIS, FOR BELIEVING IN ME; WITHOUT HIS UNDERSTANDING AND SUPPORT, THE CIMPLETION IF MY THESIS WOULD NDT HAVE BEEN POSSIBLE. 


\section{ACKNOWLEDGMENTS}

I QWE THANKS TD ALL THE MEMBERs OF MY COMMITTEE FOR THEIR SUfPORT AND time. WithoLt their intuitive opinians this pRoject coLlo Nat haVe geEN completed. I Wish to thank professgr William meminn for his Valuable time and qualitative interest. I am also Very appreciative to Professor JOHN STUART, NOT ONLY FOR HIS GUIDANCE GN MY THESIS RESEARGH BUT ALSO FOR HIS OUTSTANDING ERITIQUES. FINALLY, I WOULD LIKE TO GREATLY THANK MY Majar Professar, Gisela López-Mata, for her understanding of my ideals AND FOR HER ONGIING RESEAREH IN SUPFORT OF MY PROJECT. 
DESIGN IF AN ADEQUATE WOMEN'S ASYLUM: ANALYSIS AND ARCHITECTONIC PRIPQSAL FQR A HOME FIR WOMEN WITH CHILDREN IN NEED

BY

carmelina Álvarez-giboyeaux

FLORIDA INTERNATIONAL UNIVERSITY, 2DO4

MIAMI, FLORIDA

Professar gisela lópez-Mata, Majar professar

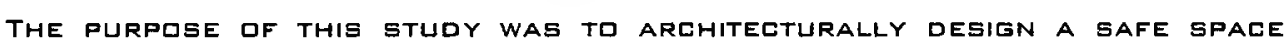
WHERE AEUSED WOMEN WITH CHILDREN CAN GO TO ENGLURAGE CHANGES IN AtTitudes, beliefs, feelings, and gehavidral patterns that hold back the PROGRESS DF VICTIMS TOWARD MLRE SATISFYING LIVES.

THIS STUDY THEN ACHIEVES THE CONDITIONS IN EXISTING BATTERED WOMEN'S SHELTERS FACILITIES IN ORDER TO UNDERSTAND THE BUILDING PROGRAMMING. Several proglems Were identified. Existing shelters typically isolate BATTERED WIMEN FROM SOCIETY, LICATING THEM FAR FROM THE URBAN CONTEXT.

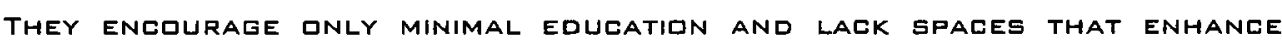
POSITIVE THINKING. CONSIDERATIONS FOR DESIEN STRATEGIES WERE DIVIDED INTO DIFFERENT VARIABLES: THE FABRIC OF THE CITY, THE SURROUNDINGS, THE PRIVATE and public spaces, and elements used in therapeutic spaces such as lighting, materiality, and natural elements. this research used SIGNIFICANT FINDINGS TO CREATE A NEW ASYLUM DESIGN TYPOLOGY, WHICH WQULD be safe during the therapeutic process and prepareg women for a SUCCESSFUL GLCIAL INTEGRATION. 
CHAPTER 1： INTRODUCTION

CHAPTER II: HISTLRICAL BACKGRDUND

A. Chronglogy of Typqlogical Develapment in Wamen's Shelters............

B. THE HISTORICAL DEVELOPMENT OF WOMEN'S RIGHTS ..............................

CHAPTER III: WIMEN, CHILDREN AND THE HIME

A. Viglence against WOMEn.

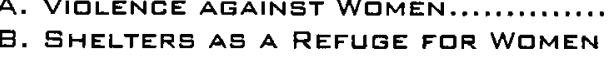

C. PRESERVING CHILDHOOD IN SHELTER

CHAPTER IV : cAsE STUDIES

A. Case Study A: Agape Wamen's Ministries in hamestead, Florida $\ldots \ldots \ldots . .24$

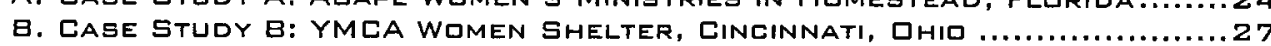

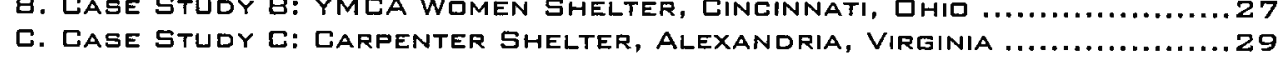

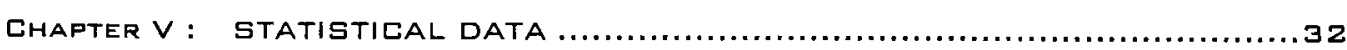

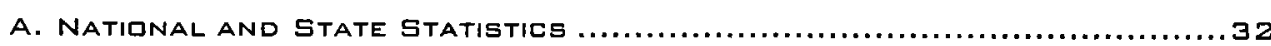

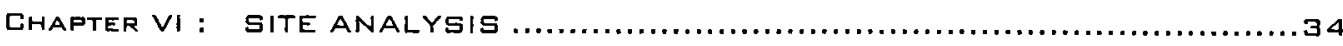

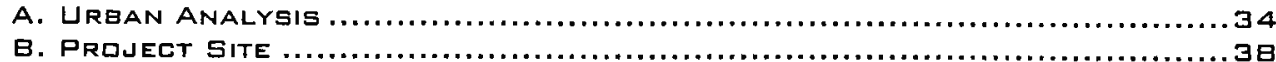

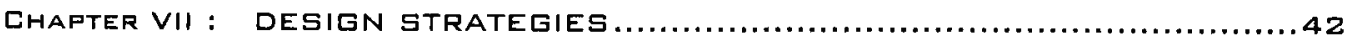

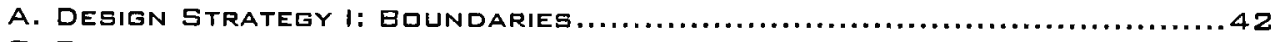

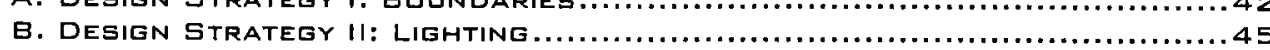

B. DESIGN STRATEGY 11 : LIGHTING
CHAPTER VIII : ARLHITECTURE FOR PROTECTION AND FACILITATION

A. SEHEMATIE MIDELS

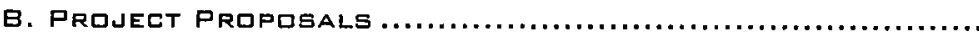

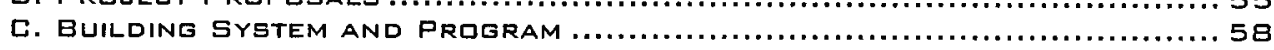

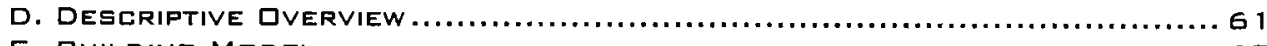

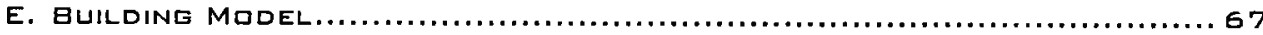

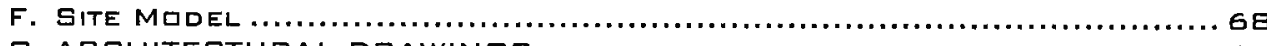

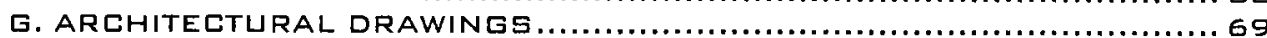

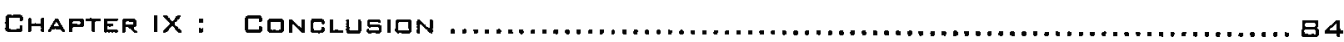

REFERENCE⿱一𫝀口. 


\section{LIST DF FIGURES}

\section{FIGURE}

1. casa di socorro di san paglo PHOTDGRAFH

2. CHILD IN SHELTER

PHOTOGRAPH

3. INTRODUETORY IMAGES

MIXED MEDIA

4. 1970S WOMEN'S BHELTER TYPDLOGY PHOTOGRAPHS

5. WOMEN's Campaigns, Late 1 BBDS PHOTOGRAPHg

6. Cecil weiner and Helen williams PHOTGGRAPH

7. WOMEN'S Rights Histarical DeVELOPMENT PHOtOMONTAGe MIXED MEDIA

a. Characteristics of Domestic ViqLence TABLE

9. IDEal Location for shelters SKETEH

10. COMMUNITY INTERACTIONS SKETCH

11. FREEDOM OF CHOICE SKETEH

12. CONTINUUM IF Social INTERACTION SKETCH

13. NEIGHEORHOLD ANALYSIS SKETCH

14. Natural Lighting in Shelter SKETCH

15. CQVER OF EOLK, CHILDHOID FOR CHILDREN IN SHELTERS IMAGE

16. CHILDREN's DUTDODR PLAY AREA SKETCH

17. RESIDENT PARKING SKETIH
18. CORRIDORS AND ENTRY, DIAGRAM SKETGH

19. Right-gF-WAY RqADs, DIAGRaM SKETCH

20. Agape Surrounding Site PHOTOGRAPH

21. MaIN guiloing of Agafe WIMEN's Ministries PHOTOGRAPH

22. Regidences df Agafe Women's Minigtries RHOTDERAPH

23. Agape shelter, New fagilities AXINOMETRIC DRAWING

24. AgApe SHELter, Aerial View AERIAL PHITOGRAPH

25. agape shelter, New facilities, plan \& Elevation ARCHITECTURAL DraWING

26. Agape shelter, New facilities, flogr plan of Typical cottages ARCHITECTURAL DRAWING

27. Agape Shelter, New fagilities, elevatian of typical cottages ARCHITECTURAL DRAWING

28. Agape Shelter, New facilities, site plan ARCHITECTURAL DRAWING

29. YMCA WOMEN'S SHELTER FLUIR PLANS AREHITECTURAL DRAWING

30. YMCA WIMEN'S SHELTER INTERIOR PHOTOGRAPHS

31. ChILDREN IN ALEXANDRia SHELTER PHOTOGRAPH

32. WOMAN IN HER ROOM PHOTOGRAPH

33. CARPENTER WIMEN'S SHELTER PHOTLGRAPHS 
35. plat maf of selected site ARCHITECTURAL DRAWING PHOTOGRAPHS

37. PHatomontage of SurRqundings of SElected Site MIXED MEDIA

38. UREAN ANALYSIS DiAgrams ARCHITECTURAL DRAWINGS

39. JAEKSON MEMORIAL HOSPITAL, 1 BUILOING PADKBON MEMG

4D. Photomantage of Selected Site PHOTIGRAPHS

41. Praject site diagram ARCHITECTURAL DRAWINGS

42. BOUNDARY SITE SKETCHES SKETCHES

43. BOUNDARY STRATEGY STUDY MiXed MEdia

44. BQUNDARY DRAWING COMPUTER DRAWING

45. BOUNDARY AS INTERIDR STRATEGY MIXED MEDIA

46. BIUNDARY AS EXTERIIR STRATEGY CoMPuter Rendering

47. Natural lighting effect SKETCH

48. East façade as lighting gtrategy COMPUTER RENDERING

49. INTERIOR HaLLWAYs AS Lighting STRATEgY COMPUTER RENDERING

50. INTERIDR VIEW IF CQURTYARD COMPUTER RENDERING

51. RoLF gtudy as Lighting STRATEgY BENDED ACRYLICS

52. RIDF VIEW As Lighting StRATEgy COMPUTER RENDERING

53. INTERIOR hallways as Lighting strategy COMPUTER RENDERING

54. Meditation rodm as lighting Strategy COMPUTER RENDERING

55. APARTMENT INTERIDRs as Lighting Strategy COMPUTER RENDERING

56. BEDRTOM AS LIGHTING STRATEGY COMPUTER RENDERING

57. CHILDCARE LOCATION DIAGRAM COMPUTER RENDERING

58. WOMEN READING WITH CHILD PHOTOGRAFH

59. Childcare Location, North View

60. Childocare Location, Rogf terrace View COMPUTER RENDERING

SCHEMATIC MODELS

Proposal a, flogr plan and sketch

63. Propdsal B, flodr plan and Madel photograph MIXED MEDIA

Propdsal c, flogr plan and SKetch

65. DESCRIPTIVE QVERVIEW DIAGRAMS

COMPUTER DRAWINGS

SECTIONAL MODEL OF
ARCHITECTURAL MODEL 
69. INTERIDR CIURTYARd, AXoNOMETRIC VIEW

86. LONGITUDINAL SECTION ARCHITECTURAL DRAWING

7D. INTERIOR CLURTYARD

87. SECTION AA COMPUTER RENDERING ARCHITECTURAL DRAWING

ARCHITECTURAL MODEL

BB. SECTION BB

architectural Drawing

COMPUTER RENDERING

B9. east elevation

ARchitectural DRAWING

90. West elevation

ARCHITECTURAL DRAWINE

91. SOUTH ELEVATION ARCHITECTURAL DRAWING

74. ROOF CANGPY, AXONOMETRIC VIEW COMPUTER RENDERING

75. REPREgENTATION OF Rogftap Garden MIXED MEDIA COMPUTER RENDERING computer Rendering

93. Wall Detail a ARGHITEGTURAL DRAWING

77. TYPICAL RESIDENTIAL INTERIDR UNIT

$$
\text { 94. WALL DETAIL B }
$$
Architectural Drawing

95. Strugtural flodr plan ARCHITECTURAL DRAWING

84. FUURTH FLOLR PLAN ARCHITECTURAL DRAWING 
CHAPTER I

INTRODUCTION

“SiNCE THE EARLY 1970 S, SHELTERS FOR VICTIMS OF DOMESTIC VIDLENCE HAVE SERVED AS HAVENS FQR HUNDREDS OF THOUSANDS OF ENDANGERED WDMEN AND CHILDREN" (5HISTACK 2001 ).

THE FACT THAT SHELTERS FOR BATTERED WIMEN HAVE GEEN IN EXISTENCE FIR GVER FQUR HUNDRED YEARS LENDS WEIGHT TO THE VALUE OF THE SUBJECT MATTER OF THIS THESIS AND CREATES A SENSE DF A CONTINUING COMMITMENT, REgARDLESS OF THE PARTICULAR SOCIAL CONSCIOUSNESS OF THE AGE, RACE, RELIGION OR SOCIAL STATUS OF WOMEN OVER TIME AND ACROSS NATIONAL BOUNDARIES. IT IS GLEAR THAT WOMEN DID NOT SIMPLY HAVE A RANDOM REALIZATION AND BEGIN THINKING IN THE MIDDLE OF THE 1970 S agout shelters as a mEANS FOR REFUge. IN SIXTEENTH-CENTURY EUROPE THE CONCEPTS OF THE AgUSED AND ABANDONED WIFE WERE COMBINED INTO the WIRd “MALMaritate," an understated term MEANing unHappily Married. (COHEN 1992). THE MALMARITATE WAs A WIDELY KNOWN AND POPULAR FIGURE IN EARLY MODERN LITERATURE. AN EXAMPLE of AN EARLY SHELTER WAS IN ONE OF THE oldest cities in sixteenth-century italy, called the casa del SqCcorso di

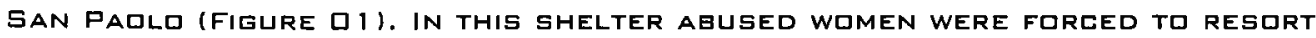
TO PROSTITUTION FOR ECONOMIC SURVIVAL (COHEN 1992 ).

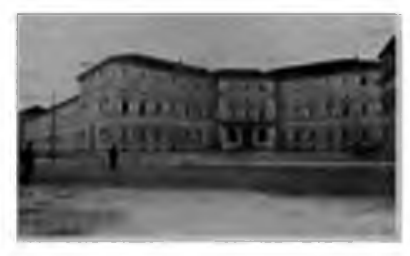

FIGURE CASA DI SOCCORSO dI SAN PAOLO
THE LINKAGE GETWEEN THE HISTORY OF WOMEN'S SHELTERS AND THE HISTORY OF WOMEN'S RIGHTS ADDED A MOTIVATING TOPIC TO THIS THESIS. THE FACT THAT WOMEN'S SHELTERS AND SIMILAR ENTITIES INCREASED IN NUMBER WAS A RESULT OF THE RECOGNITION OF WOMEN'S RIGHTS.

THE HISTORY OF WOMEN'S SHELTERS REVEALS THAT NOT UNTIL 1972 WERE WOMEN'S SHELTERS EXPOSED TO THE PUgLIC EYES (SHOSTACK 2001). AROUND THAT TIME, THE SHELTER MOVEMENT GREW FROM A HANDFUL OF SMALL INFORMAL FACILITIES TO A NATIONWIDE NETWORK OF PROTECTIVE PRGgRAMS, MANY WITH LARgE POPULATIONS and substantial resqurces. THEIr management has become increasingly COMPLEX WITH a tREMENDQUS INCREASE IN RESIDENTS. IN THE MIDdLe of THE 1970s, SHELTER IPERATORS HAD LITTLE EXPERIENCE TO GUIDE THEM IN TERMS OF PLANNING AND MANAGING THEIR ESTAGLISHMENTS. HOWEVER, QVER THE LAST tHREE DECADES MUEH HAS BEEN LEARNED ABdUT SHELTER IPERATIONS.

THE IDEA FOR THE STUDY OF THE ARCHITECTURAL DESIGN AND USER NEEDS OF A

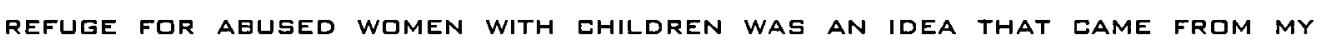
PREVIOUS STUdY ON GENDER AND ARCHITECTURE. HOWEVER, THE TOPIC OF GENDER AND ARCHITECTURE MADE TOO BROAD A RESEARCH TOPIC TO CONSIDER FOR THIS THESIS. NONETHELESS, AFTER CAREFULLY EXAMINING AND STUDYING GENDERED SPACES THE URGENT NEED FOR KNOWLEDGE ON WORKING WITH A WOMEN'S REFUGE PROJECT BECAME APPARENT. THUS, THE COLLECTION OF INFORMATION FROM EXISTING WOMEN'S SHELTERS FOR THIS TYPE of RESEAREH WAS VERY INTENSE AND complicated to ogtain, due to the discretion of shelters as a security meAsure. 


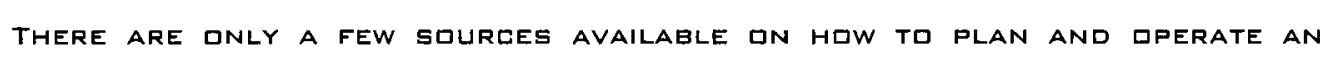

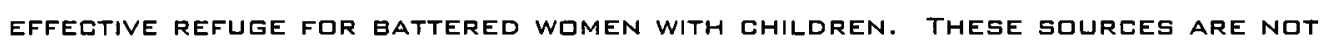
DNLY AREHITECTURAL GUIDELINES QR CONCEPTUAL IDEALS BUT ALSO ORGANIZATIONAL plans for the building facilities. THEse organizational plans will be MENTIONED IN FURTHER CHAPTERS TO BETTER EXPLAIN DESIGN STRATEGIES, PROGRAM DESIGN, CIRCULATION BETWEEN THE GUILDINGS, AND THE SPECIFIC SPACES ADDED TO the program. ILlustrations of these organizational plans were gatained FROM SKETCHES BY DR. VERDERVER OF UCLA IN 1985, IN WHICH HE QUTLINES THE CONTENT AND LONTEXT OF A SHELTER AND THE POSSIBILITIES IN CREATING A SAFER SETTING IN A SHELTER FOR ABUSED WOMEN WITH CHILDREN.

SOME OF DR. VERDERVER'S ARGHITECTURAL gUIDELINES HAVE BEEN USED GY MANY SHELTER PLANNERS DURING THE LAST TWO DECADES. HOWEVER, THIS THESIS IS A MODERNIZATION OF DR. VERDERVER'S 1985 STUDY PLANS. THIS MODERNIZATION TAKES INTO CONSIDERATION AN IMPORTANT NEW VARIABLE, WHICH IS THE LARGE

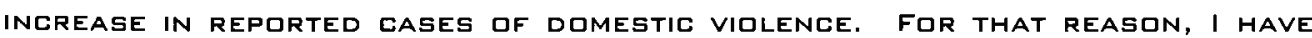
formulated design strategies that essentially address the NeEds fur PROTECTION AND FACILITATION FIR WOMEN AND CHILDREN IN SHELTERS. THEREFIRE, THE DESIGN DF GUIDELINES AND IDENTIFICATION OF NEEDS IN SHELTERs far BATTERED WOMEN WERE CONDUCTED USING DESIGN STRATEGIES TO BE FOLLOWED DURING the course dF the program plan and architectural design DEVELOPMENT.

THE METHQDOLOGY FOR THIS THESIS WAS BASED GN REAL FINDINGS. THE FIRST TASK WAS THE IDENTIFICATION OF THE DOMESTIC VIOLENCE PROBLEM AND THE NEED FOR A shelter. The second Was collecting statistical data from the Miami-dade

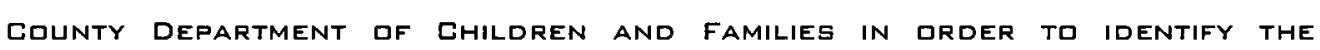
community with the most reported cases in the miami area. finally, ADDITIONAL INFGRMATION WAS GATHERED ABOUT THE ACHIEVEMENT OF SHELTERs,

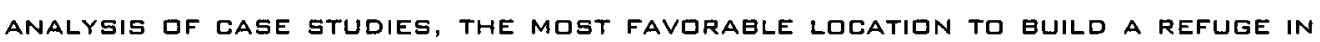
Miami, the quality of spaces, and issues with existent buildings. as a result, the design of strategies, schematics, and production of ARCHITECTURAL DRAWINGS WAS THE LAST PART FOR THE COMPLETION GF THIS THESIS. IT IS IMPORTANT TO MENTION THAT THE PRIMARY FOCUS OF THE INVESTIGATION WAS TO FIND THE BASIC REQUIRED SPACES FIR WOMEN, CHILDREN, AND STAFF, NONETHELESS, WHERE to LOCATE A SHELTER WAS AN ESSENTIAL AND CONTROVERSIAL TOPIC OF DISCUSSION COVERED DURING THE COURSE OF THE RESEARCH.

As mentioned befare, the actual case studies were used as an eValuation

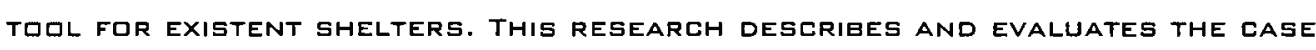
STUDIES AS A WAY OF UNDERSTANDING THE VARIOUS PROGRAMS THROUGHOUT THE united states. THE INFarmation collected from the gase studies aided the PROCESS OF SHAPING THE DESIGN STRATEGIES IN THIS ARCHITECTURAL PROGRAM. THE case studies SELEcted facilitated MY understanding of the shelter's FUNDAMENTALs, THE REQUIRED sPACEs, AND THE RDLEs of AGENGIEs SUPPORTING THE SHELTER.

IN ADDITION, THE COMPREHENSIVE REVIEW OF SHELTER NEEDS AND REQUIREMENTS WAS conduCted ON THE Basis of INFORMATION THAT GAME FROM DIFFERENT

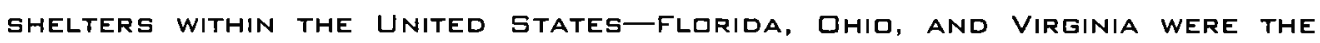

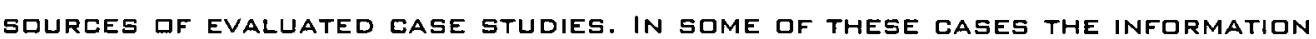

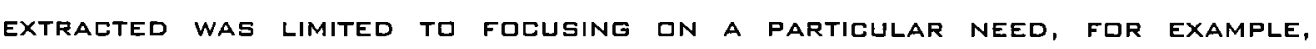


FURNISHINGS QR THE TYPES OF SERVICES SHELTERS MUST PROVIDE. IN OTHER CASES, I have gained an understanding concerning the gharagteristics and the NEEDS OF THE VICTIMS, GROUP LIFE IN SHELTERS, SUPPORTIVE SERVICES, COMMUNITY SUPPORT, AND PRESERVING CHILDHOOD IN SHELTERS.

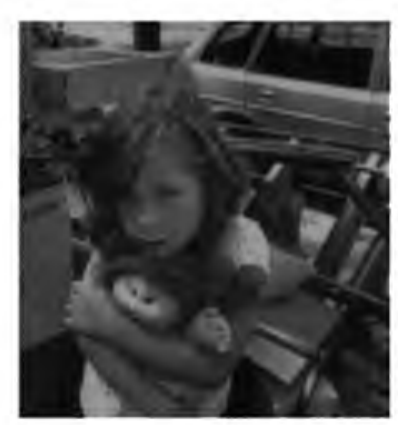

\begin{tabular}{|c|l|}
\hline FIGURE & \\
\hline Q2 & CHILD IN SHELTER \\
\hline
\end{tabular}

THROUGHOUT THE COUNTRY, SHELTERS HAVE INCREASED THEIR ABILITY TO DEAL WITH THE GROWTH IN THE NUMgER OF CASES, AND THE COMPLEXITY OF DOMESTIC VIOLENCE. THE EVALUATION OF DR. VERDERVER'S SKETCHES PROVIDED IMPROVED solutions to apply to a new shelter design that wOULd deal With the MENTIONED VARIAGles. DURING THE SCHEMATIC DESIGN PROCESS THE INTENT WAS TO DEVISE STRONG STRATEGIES AND TO TAKE INTO CONSIDERATION DR. VERDERVER'S SQLUTIONS TO THE VARIOUS ISSUES. THESE STRATEGIES MET CERTAIN REQUIREMENTS

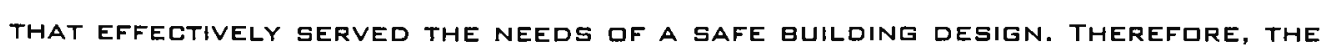
STRATEGIES OF BOUNDARIEs, LIGHTING, AND ATTACHMENT WERE the ESSENTIAL elements integrated inta the complexity of the program, as well as the

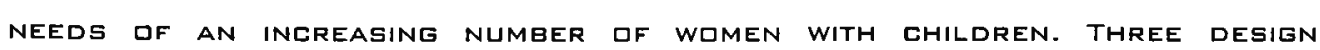
STRATEGIES WILL EE FURTHER DISCUSSED IN THIS BOIK.
THE SITE ANALYSIS WAS PARTITIONED INTO THREE MAJUR VARIABLES: THE FAgRIC of the gity, the surroundings, and the public/private spaces. also, the PROJEGT ANALYSIS CONSIDERED ELEMENTS USED IN THERAPEUTIC SPACES SUEH AS Lighting, materiality, spaces for graup meditation, and plubli shared SPACES. THE DESIGN OF THESE ELEMENTS IS INTENDED MAKE THE RESIDENTS FEEL that they are not alone. Perhafs the most difficult challenge in the design of the structure Was to design a shelter that WOULd have Noticeable PRIVATE AND PUBLIC spaces.

THIS THESIS DISCUSSES ISSUES AT ALL LEVELS IN WOMEN'S LIVES BOTH HISTORICALLY AND IN MODERN SOCIETY. IT IS NDT ONLY AN ARCHITECTURAL DESIGN RESEARCH project but also a social and fungtional analysis. THEREfore, the ARCHITECTURE CQULD BECOME A BUILDING OF MEANING FOR QUR COMMUNITIES IN THE miami area. AdDitionally, the architectural design for the shelter in ADDITION TO GEING A MANIFESTATION GF FUNCTION, PROTECTION AND DEFENSE, ALSO

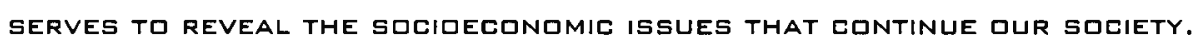

I concluded this thesis realizing that this architectural design is an EXPRESSION NOT INLY OF DESIRE BUT ALSD OF THREE GREAT NEEDS: THE NEED TO CONTINUE ADDRESSING WIMEN'S ISSUES, THE NEED TO PROVIDE DPTIONS FIR WOMEN

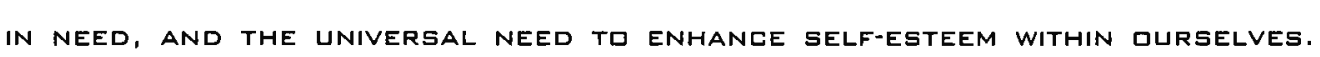
HENCE, this REALIZATION IS THE basis for the strategies and considerations gF THIS PRIGRAM FIR AN ARCHITECTURAL REPRESENTATION OF WOMEN IN NEED. 


\begin{tabular}{|c|l|}
\hline FIGURE & \\
\hline D 3 & INTREDUCTORY IMAGES \\
\hline
\end{tabular}
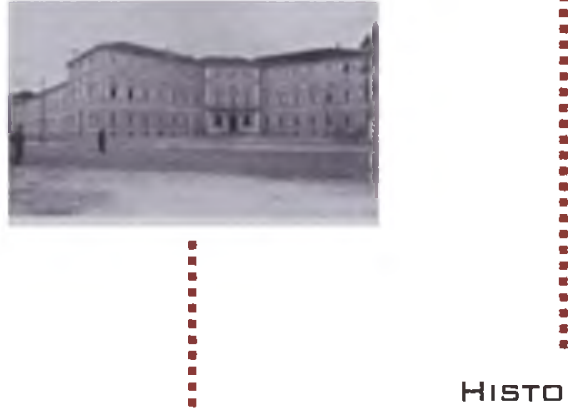

HISTORY DF WDMEN'S

RIGHTS

HISTDRY GF

WDMEN'S

SHELTERS
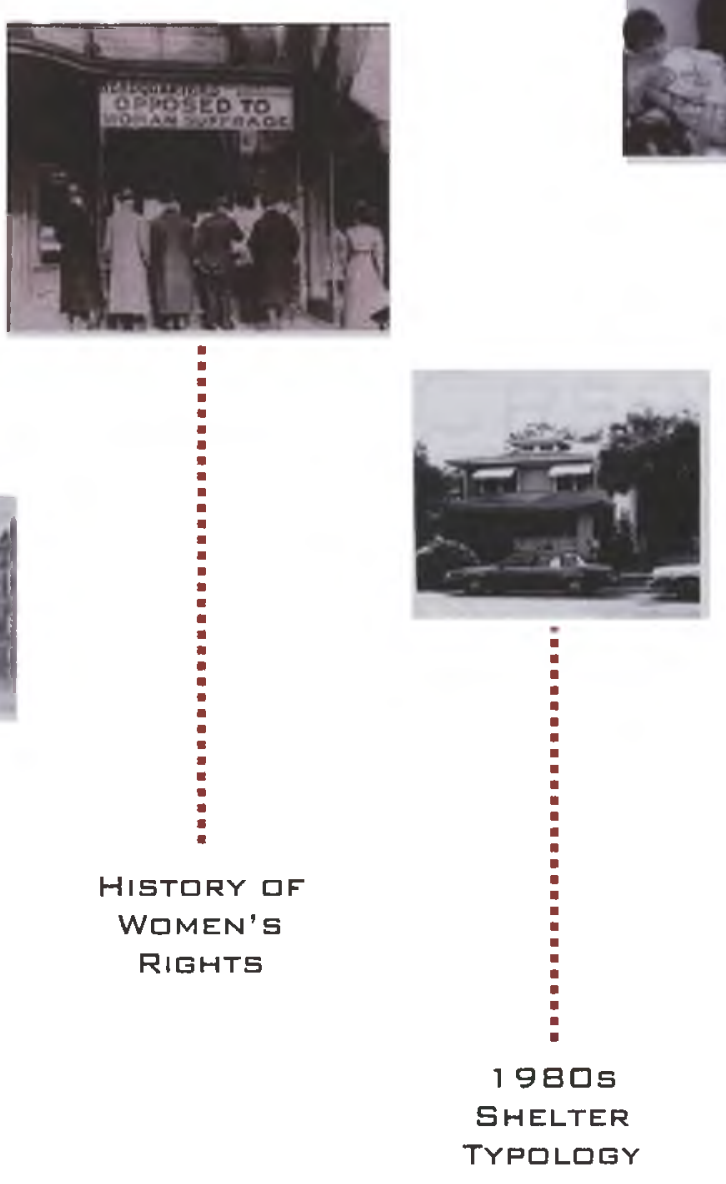

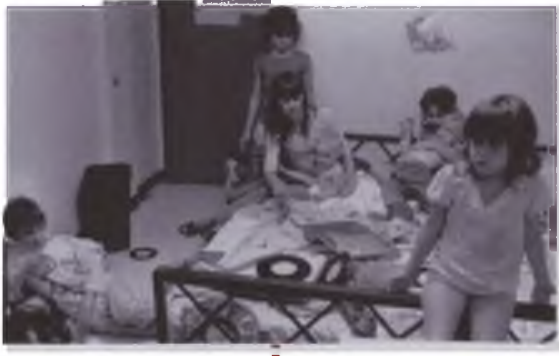

.

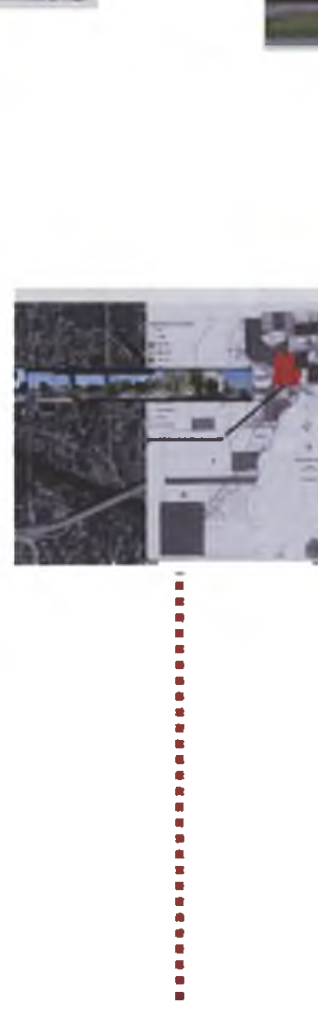

口F WDMEN

WITH

CHILDREN

STATISTICAL DATA
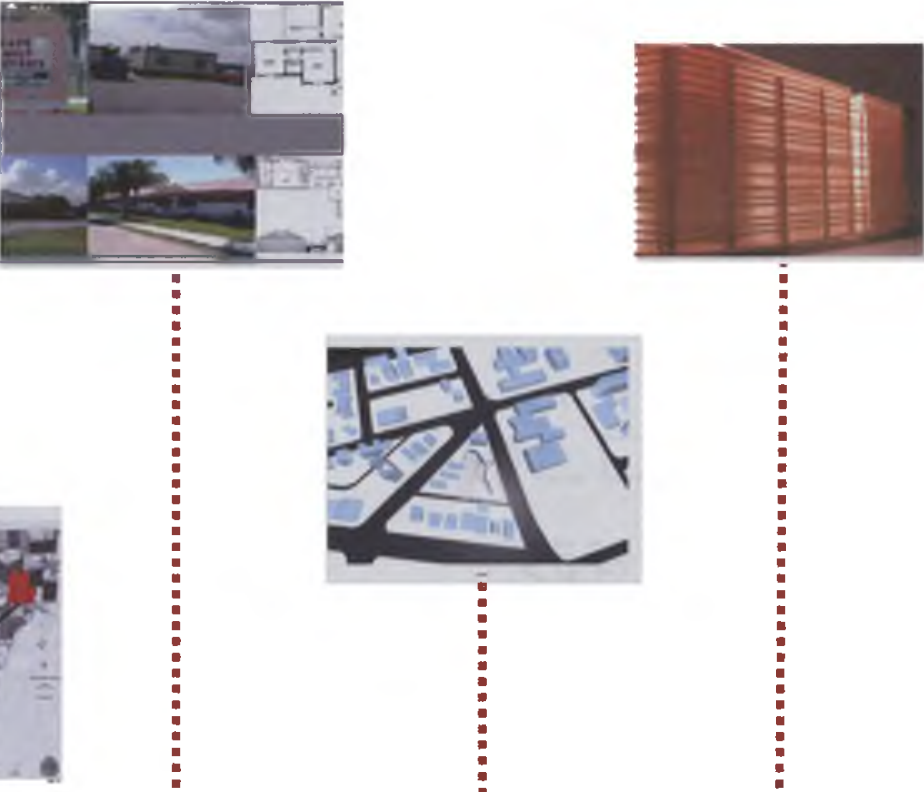

BILNDARY

LIGHTING ATTACHMENT
CASE

STUdIES

CDNCEPT CONTEXT 
THE HISTORY DF WDMEN SHELTERS HAS HAD FQUR HUNDRED YEARS DF SERVICES.

"THERE HAS BEEN A NEED FOR AGUSED WIMEN SHELTER IN EVERY SMALL COMMUNITY PERHARS EVERYWHERE ARLUND THE WORLD."

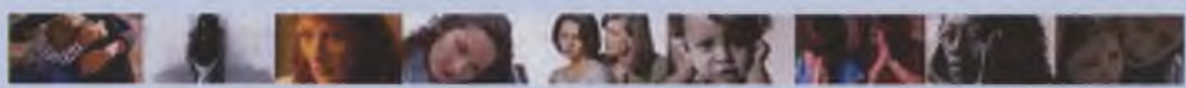
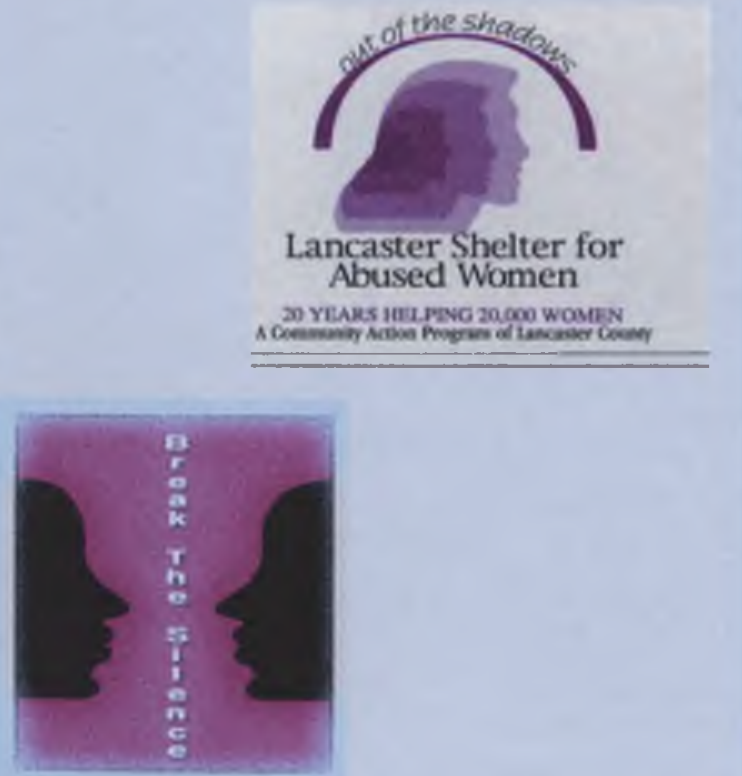

BATERED WOMENS

$$
\text { 大旦影 }
$$

SUPPORT SERVICES

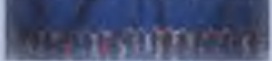
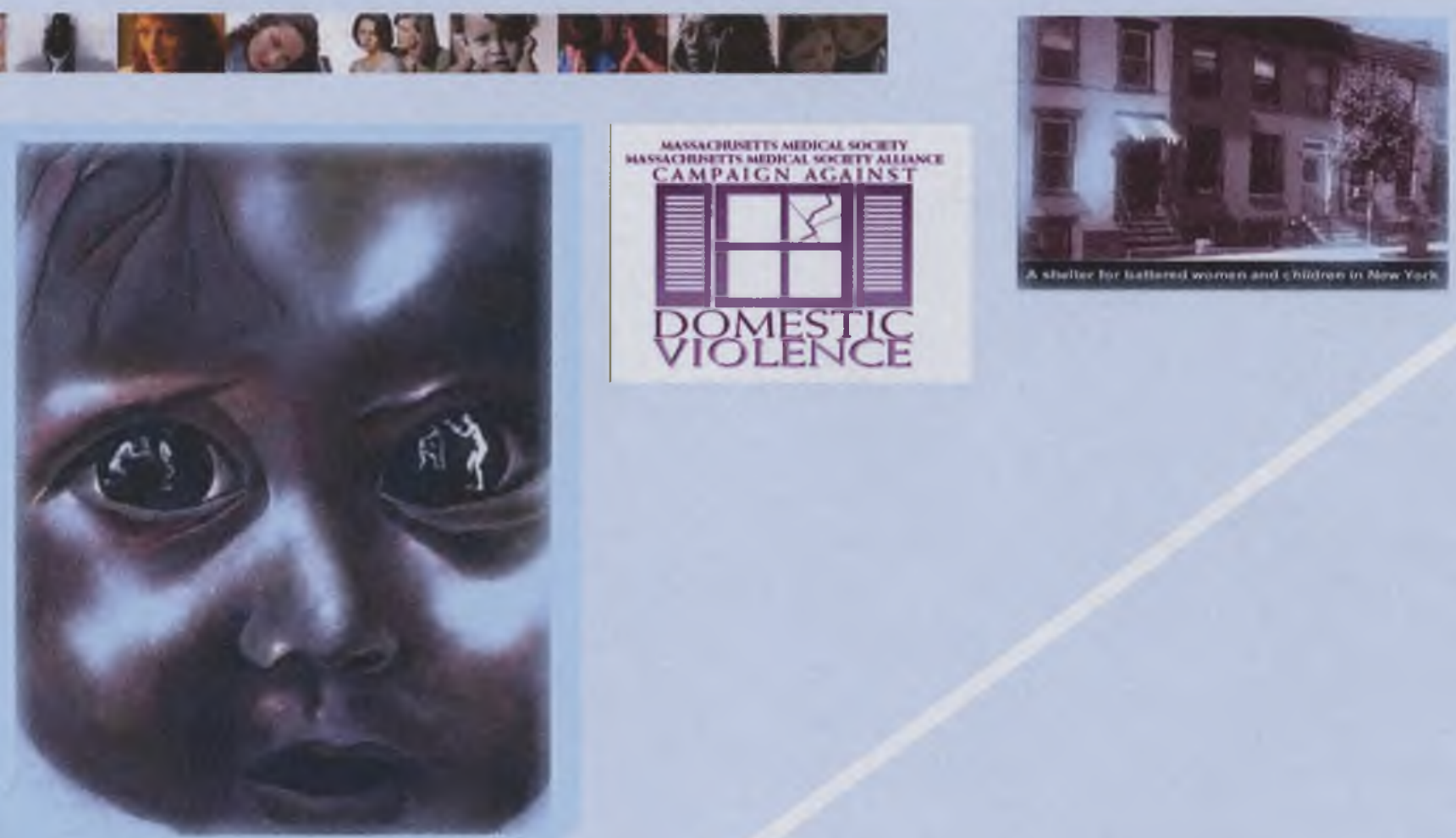

Chapter II 
CHAPTER II

\section{HISTORICAL BACKGROUND}

\section{A. CHRONGLGGY IF TYPOLGGY DEVELOPMENT IN WOMEN'S SHELTERS}

Far the purpases of this study, I did NOt cansider the decade of the $1970 S$ AS THE LATEST VERSION DF THE WOMEN'S SHELTER BOOM OR THE WOMEN'S liberation movement as the only relevant facts. also, the researeh EXPLORED DEEP INTO THE HISTORY OF WOMEN'S ROLES IN QUR SOCIETY. IT IS SIGNIFICANT TO MENTION THAT WOMEN FOR HUNDREDS IF YEARS HAVE STRUGGLED

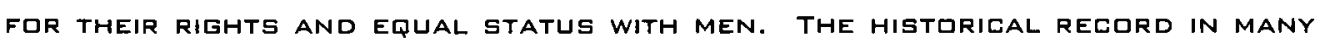
CULTURES SHOWS THAT UNTIL PERHAPS A CENTURY AGO MARRIED WOMEN LIVED IN THE SHADOW OF THEIR HUSBands, WHICH IS STILL TRUE AND EVIDENT IN MANY places todaY.

THE ancient gracles believed that groups of WOMEN Were a sYmbdl af getrayal and dishonesty. HOWEVER, oracles in Later times Were more in LiNe With WOMEN'S LIBERATION. THEse gROUPS WERE INTERPRETED As SIGNS OF INCREASING PROSPERITY. IT WAS BELIEVED THAT IF YQU OBSERVED A PREGNANT WOMan in your dream, you Were likely to have an "emgarrassment of

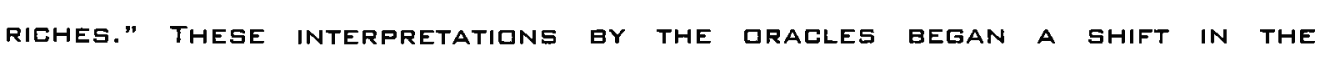
PERCEPTION OF WOMEN IN SOCIETY (PAMEROY 1995 ).

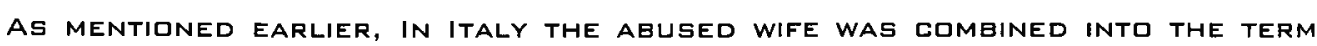
"Malmaritate," an understated term meaning unhappily married. the "Malmaritate" was a widely known term in Eastern civilizations and also a PLPULAR FIGURE IN EARLY MODERN LITERATURE. BEING UNHAPPILY MARRIED WAS A state pREsented as the WIMAN's problem, to WHich only she had the SOLUTION BY MODIFYING HER LIFE (COHEN 1992). IN THOSE TIMES, VIOLENCE WAS NOT ADDRESSED AS A PROBLEM THAT THE MALE MUST CONTROL, BUt RATHER As A Situation that the fEMALE MUST ENDURE. IT WAS THE WOMEN WHO HAD TO FIND A solution or try to Make the marriage wark again. THE refuge became EXTREMELY NECESSARY FIR WOMEN WHO COULD NOT AFFORD TO LEAVE THE CITY OR did Not have families Who would support them. Many af these early SHELTERS FOR MALMARITATE WIMEN APPEARED IN ITALY IN THE FIFTH AND SIXTH CENTURIES (FERRANTE 1992 ).

SHERILL CIHEN IN HER BOOK, THE EVQLUTION OF WOMEN'S ASYLUMS SINEE $1500 S$, SHOWS THE RELATIONSHIP BETWEEN TODAY'S BATTERED WOMEN SHELTERS AND EARLY ASYLUMS. SHE geLIEVES THAT TODAY'S SHELTERS ARE BASED IN ECINOMIC AS WELL as social criteria. However, that is only a general basis of what CONSTITUTES A SHELTER IN MODERN TIMES.

Mareover, cahen also implies that in early times, agused women were PERHAPS THE MOST POORLY TREATED HUMAN BEINGS GY INSTITUTIONS SUCH AS HOSPITALS, AND BANKS OR OTHER FINANCIAL INSTITUTIONS. WOMEN KNEW WHICH

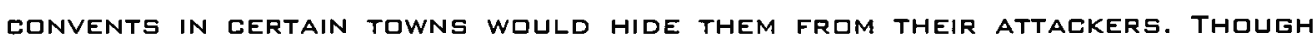
SLME IF THESE WIMEN TRIED TO TURN TO PENITENCE AND BECIME NUNS, THEY WERE unagle to because they were married in the eyes of the chureh. SUBSEquentLy, IN THE LATE siXTEENTH-century, charitable grqups started FORMING AS CONFRATERNities AND CO-SORDRITIES TO SPECIFICALLY SERVICE MALMARITATE WOMEN (CDHEN 1992 ). 
the casa del sogcorso dI san paglo in sixteenth-century bologna INCLUDED PROSTITUTES, WOMEN IN ABUsive MARRIAGEs (MALMARITATES), Victims of RAPE, AND WOMEN BETRAYED BY SUITORS WHO BROKE PROMISES OF MARRIAGE IN EXCHANGE FIR THEIR VIRGINITY (FERRANTE 1990).

THE HISTORY IF WOMEN'S SHELTERS DATES BACK FQUR HUNDRED YEARS services. Frant-line service providers, humanitarian grganizatians, WOMEN'S GROUPS, RELIGIOUS GRIUPS, AND PUBLIC OFFICIALS WERE INVGLVED THEN

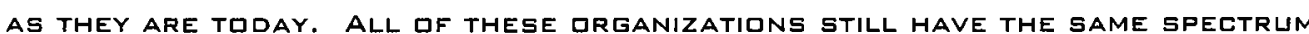
of IDEAS ABOUT HOW TO RESOLVE THE ISSUES IN A COMPASSIONATE WAY.

MOST OF THE PROVISIONS FIR GATTERED WOMEN'S SHELTERS WERE VEILED FROM GUR KNOWLEDGE SINGE MOST OF THE BOOKS WERE KEPT WITHIN PRIVATE WOMEN'S grganizations and neVer published until a feW degades ago. The non-public

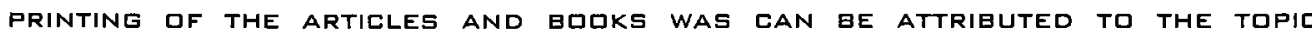
ALMOST BEING PROHIBITED. IT IS TO SAY THAT THE RESEARCH INTO THIS TOPIC SHOWS THAT THE HISTORY OF BATTERED WOMEN'S SHELTERS CAME INTO PUBLIC CONSCIIUSNESS ONLY THREE DECADES AGO.

THE SHORT HISTORY OF THE MOST RECENT ASYLUMS BEGINS WITH A SMALL HOME FOUNDED IN ENGLAND bY A WOMAN NAMED ERIN PIZZEY IN 1971. THE INSTITUTION WHICH SHE NAMED CHISWICK WIMEN'S AID, IS GENERALLY CREDITED WITH BEING THE FIRST SHELTER FIR BATTERED WIMEN. IT WAS CERTAINLY AMONG THE FIRST AND HAD THE MOST PUELICITY af ALL EARLY SHELTERS IN ENGLAND. FROM PIZzey's IDEALS SHELTER PROGRAMS SPREAD QUICKLY FROM BRITAIN TO OTHER COUNTRIES INCLUDING the united States (ShISTACK 2001 ).

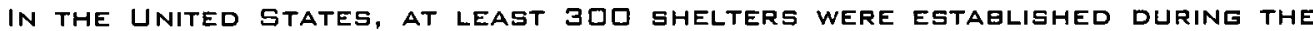
1970 (SHOSTACK 2001). THE THREe case studies eVALUATED IN THIS THEsIS ARE SIMILAR TO THESE SHELTERS FORMED IN FLORIDA GETWEEN 1975 AND 1995. THE HOWARD SHELTER IN GITY OF JACKSONVILLE REFLECTS THE TYPOLOGY OF EARLY Asylums in this country (FIgURE 4). TIDAY, facilities are still in the same CONDITION BUT OTHERS ARE VERY DIFFERENT FROM THE TINY AND INFORMAL BASES THEY USED TO WLRK WITH. GOVERNMENT AND PRIVATE FUNDS HAVE EXPANDED TO HELP ACCOMMODATE MANY MORE WOMEN IN SHELTERS AND PROVIDE THEM WITH SUPPORT SERVICES. THEREFORE, THE PROGRAMMING GIVES A SENGE DF A CONTINUING COMMITMENT REgARDLESS OF THE PARTICULAR SOCIAL CONSCIOUSNESS OF THE AGE, RACE or SOCIAL STATUS OF WOMEN GVER TIME. WOMEN DiD NOT JUST WAKE UP IN the Late nineteenth century and start lodking for a place to leave the ABUSE, HISTIRY REVEALS THAT WOMEN'S SHELTERS ARE WIRKING INSTITUTIONS FROM EARLY TIMES. 

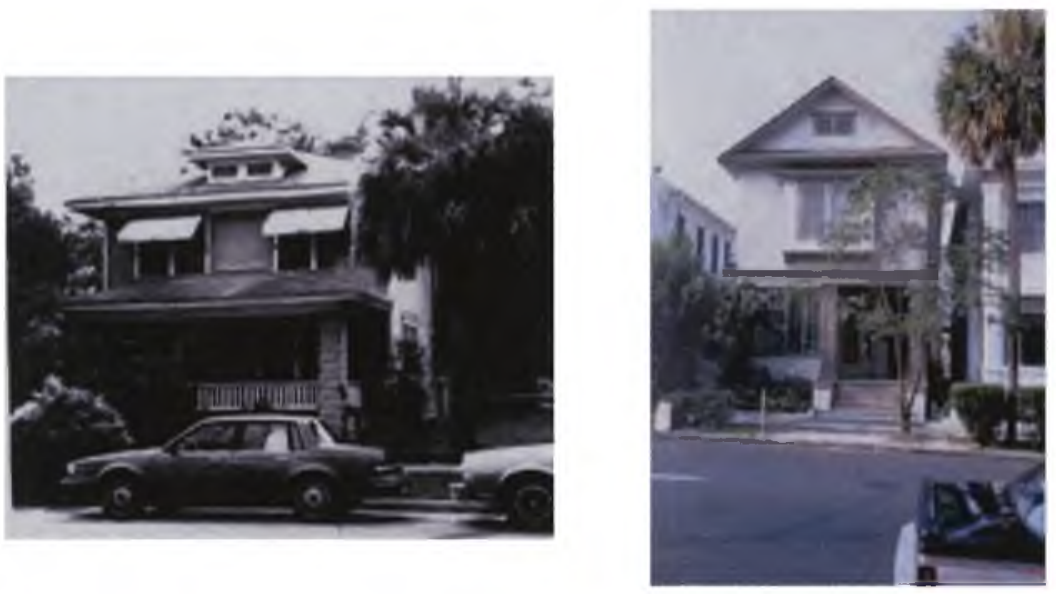

FIGURE

Q 4 1970S WIMEN's SHELTER TYPOLGGY

B. The historical DeVELIPMENT of WOMEN'S Rights

THE LINKAgE BETWEEN THE HISTORY OF WOMEN'S RIGHTS AND HISTORY OF WOMEN

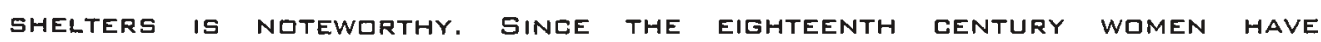
struggled to establish their rights af equal status with men. The DEVELIPMENT OF WOMEN'S RIGHTS HAS BROUGHT PLIGHT IF ABUSED WIMEN INTO THE MAINSTREAM, HAS PROMUTED AN INGREASED UNDERSTANDING AND ATTRACTED

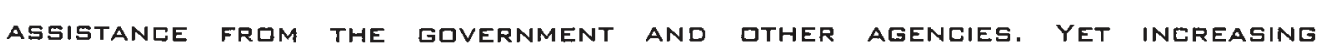
AWARENESS OF THE PROBLEM WILL REMAIN A TASK Far FUTURE GENERATIONS TO cIME.

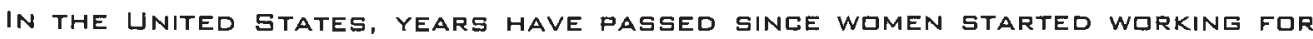
THEIR RIghts. IN THE EIGHTEENTH EENTURY A DEELARATION aF SENTIMENTS WAS DRAFTED. DURING that tIME, PATRIOTIC WOMEN WORKED the DEclaration of
SENTIMENTS CAMPAIEN GY SHARING THEIR gELIEFS OF IMPROVING THE CQUNTRY'S ideals. They saw their mission as helping the country keEp its promise of BETTER AND MORE DEMOCRATIC PRINEIPLES FOR ITS EITIZENS. WOMEN PREPARED THEMSELVES FIR THE EVENT DECLARATION OF SENTIMENTS IN WHAT PROVED TO BE A gRILLIANT CAMPAIGN FIR WOMEN'S RIGHTS LINKED DIRECTLY TO A POWERFUL

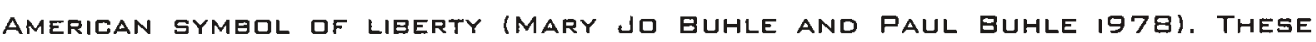
WORDS FRAME THEIR ARGUMENTS:

"WE HILD THESE TRUTHS TO BE SELF-EVIDENT; THAT ALL MEN AND WOMEN ARE CREATED EqUAL; THAT THEY ARE ENDIWED GY THEIR CREATOR WITH GERTAIN INALIENABLE RIGHTS; THAT AMONG THESE ARE LIFE, LIBERTY, AND THE PURSUIT IF HAPPINESS." DECLARATION OF SENTIMENT, 1 B56 (MARY JO BUHLE AND PAUL BUHLE HAPPINE
$1978)$.

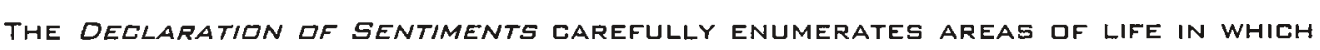
WLMen were treated unjustly. The grievances numbered eighteen. the INTRODUCTION IF THE DICUMENT STATES:

"THE HISTORY OF MANKIND IS A HISTORY DF REPEATED INUURIES AND USURPATIONS ON THE PART OF MAN TOWARD WUMAN, HAVING IN DIRECT OBJECT THE ESTABLISHMENT OF AN ABSOLUTE TYRANNY QVER HER. TO PRIVE THIS, LET FACTS BE SUBMITTED ta A CANDID WORLD." DEcLaRATION OF SENTIMENTS, 1856 (MARY Ja BUHLE AND PAUL BUHLE 1978 ).

THE Declaration then discloses the specifics:

- married women were legally dead in the eyes of the law.

- women were not allowed to vote.

- wamen had to submit to laws when they had no vaice in their FORMATION.

- married women had na property rights.

- husbands had legal power qver and responsibility for their wives TO THE EXTENT THAT THEY EIULD IMPRISON IR BEAT THEM WITH IMPUNITY. 
- divorce and chilo custody laws favored men, giving no rights to WOMEN.

- Women had to pay property taXes although they had No REPRESENTATION IN THE LEVYING dF THESE TAXES.

- Most occupations Were closed to Women and WHen Women did Work THEY WERE PAID ONLY A FRAETION OF WHAT MEN EARNED.

- Wumen were nat allowed to enter professions such as medicine or LAW.

- women had no means to gain an education since no college dr UNIVERSITY WIULD ACGEPT WOMEN STUDENTS.

- With only a few exceptidns, women were nat allowed to participate IN THE AfFalRs of THE CHURCH.

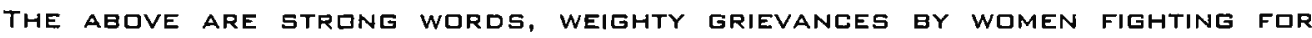
Justice. THIS was Just 70 years after the Revolutignary war. THE Declaration df Sentiments gPelled out what was the status gf EuRapeanAMERICAN WOMEN IN 1B48, WHILE IT WAS GONSIDERAGLY WORSE FOR ENSLAVED BLACK WOMEN (MARY J

the Declaration of Sentiments draft continues:

"NOW, IN VIEW OF THIS ENTIRE DISENFRANCHISEMENT OF ONE-HALF THE PEOPLE OF THIS CQUNTRY, THEIR SOCIAL AND RELIGIQUS DEGRADATION — IN VIEW OF THE UNJUST LAWS ABQVE MENTIONED, AND BECAUSE WDMEN DO FEEL THEMSELVES AGGRIEVED, DPPRESSED, AND FRAUDULENTLY DEPRIVED OF THEIR MOST SACRED RIGHTS, WE INSIST THAT THEY HAVE IMMEDIATE ADMISSION TO ALL THE RIGHTS AND PRIVILEGES WHICH BELONG TO THEM AS CITIZENS OF THESE UNITED STATES" (DEglaration dF SENTIMENTS, 1856).

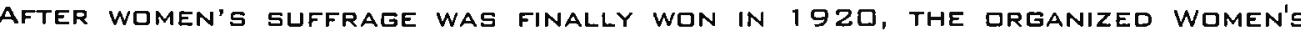
Rights MOVEMENT CONTINUED ON IN VARIOUS DIRECTIONS (FIGURE 5). THE MAJURITY

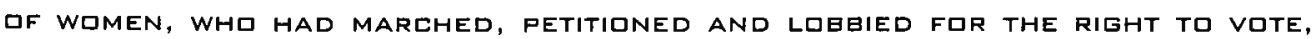
SEEMED TO gE GROWING WITH TIME. THE WOMEN'S RIGHTS MISSION WAS AN INGIING
STRLGGLE THAT WAS ONLY ADVANCED, NOT SATISFIED BY MANY WDMEN'S CAMPAIGNS THROUGHOUT THE COUNTRY (MARY J BUHLE AND PAUL BUHLE 1978).

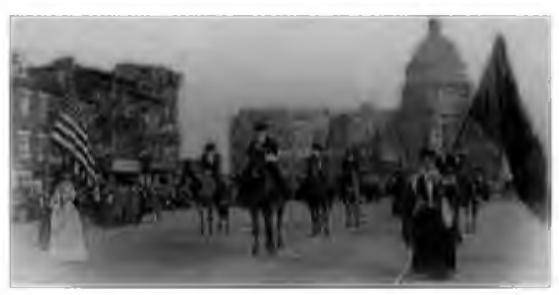

\section{FIGURE}

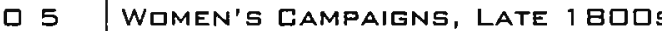

Therefare, the wamen's gureal of the Department of labgr was Estaglished to gather informatign AgOUT the situatian of WOMEN AT WIRK, and to gattle for changes it found were needed. Many women became actively inVolved With strikes in favgr of legislatidn to protect female LABORERS FROM ABUSE AND UNSAFE WORKING CONDITIONS. THE MAJURITY IF THE WOMEN INVOLVED DID NOT haVe a formal EDUCATION, BUT GeCil WIENER AND Helen MEWilliam (SEe figure 6), WHa Were the first tWo WOMEN IN UNited STATES history to EARN LAW DEgREes, gecame VERY MUCH INVDLVED WITH IN THE LEGISLATIVE PROCESS TO SECURE AND PROTECT WOMEN'S RIGHTS IMARY JO BUHLE AND paul BuHLe 1978). 


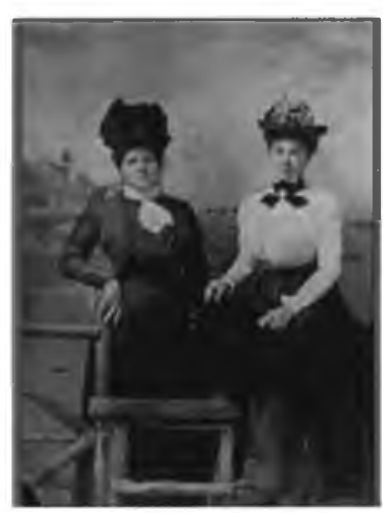

\begin{tabular}{|c|l|}
\hline FIGURE & \\
\hline Q 6 & CECIL WEINER AND HELEN WILLIAMS. \\
& FIRST WOMEN TO GRADUATE FROM UB LAW SCHODL \\
\hline
\end{tabular}

in the late 19205 , the national Wamen's party togk the next step. They

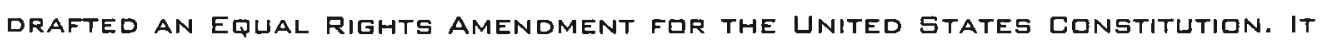
WOULD ENSURE THAT “MEN AND WOMEN WLULD HAVE EqUAL RIGHTS THROUGHOUT

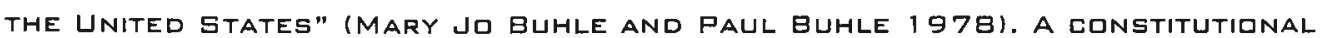
AMENDMENT WOULD APPLY UNIFORMLY, REGARDLESS IF WHERE A PERSON LIVED. After the canstitutional Amendment was passed WOMEN felt incredigly STRONG TD STEP FORWARD AND STAND FOR THEIR RIGHTS NEXT TI MEN.

The secund wave df the wamen's movement was nut included in the DECLARATIIN GF SENTIMENTS. IT WAS THE BIRTH CONTROL MOVEMENT, INITIATED BY A public health nurse named margaret sanger. The idea df a woman's right to CONTROL HER OWN BODY, AND ESPECIALLY TO CONTROL HER IWN REPRDDUCTION AND SEXUALITY, ADDED A NEW DIMENSION TO THE IDEAS OF WOMEN'S LIEERATION AND THE ideals of creating WOMEN's asylums. This maVement not anly ineluded
EDUCATING WOMEN ABQUT EXISTING BIRTH CONTROL METHODS, IT ALSO GENERATED A New belief that mOdern WOMEN MUSt ge able to decide far themselves WHETHER THEY SHOULD BECOME MOTHERs, AND WHEN. FUR DECADEs, MARGARET SANGer AND her supporters faced DOWN AT ANY INTENT to ENFarce the ABORTION LAW (MARY JO BUHLE AND PAUL BUHLE 1978).

IN THE SECDND WAVE, THE GQVERNMENT STILL DENIED WOMEN THE RIGHT TO GIRTH CONTROL. IN 1936, A SUPREME COURT DECISIIN DECLARED BIRTH CONTRDL

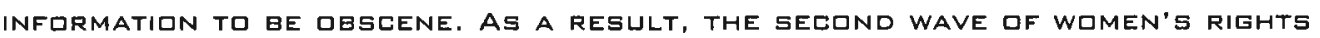
WAS TEMPQRARILY BUT A BRAVE ATTEMPT THAT EQNELUDED UNSUCCESSFULLY.

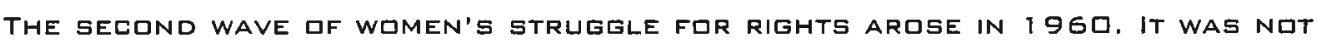
UNTIL 1965 THAT MARRIED CQUPLES IN ALL STATES COULD DBTAIN CONTRAEEPTIVES legally (Mary Jo Buhle and paul Buhle 1978). What qCCuRRed in that

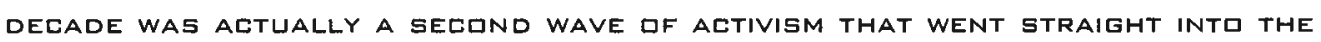

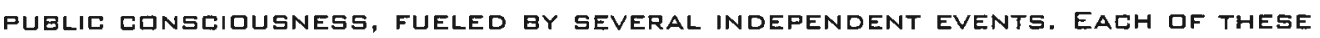
EVENTS BRIUGHT A DIFFERENT QVERVIEW INTO THE MOVEMENT. FIRST, THE WOMEN'S Bureal af the Department of Labor in 1961 considered it to be the

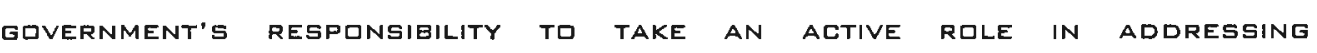
discrimination against Wamen. Therefore, President Kennedy convened a COMMISSION IN THE STATUS IF WOMEN. THE REPIRT ISSUED BY THAT COMMISSION IN 1963 ACKNOWLEDGED DISCRIMINATION AEAINST WOMEN ALMOST IN EVERY AREA OF

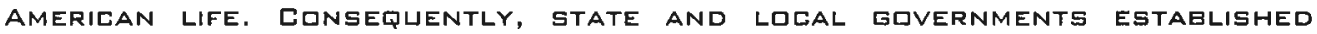
THEIR OWN COMMISSIONS FOR WOMEN, TO RESEARCH CONDITIONS AND SUGGEST

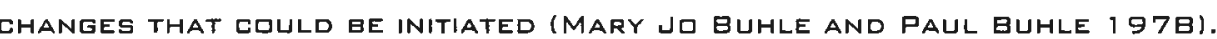


THUS, IN LATE 1964 tWQ EVENTS BECAME sugstantially IMPRRTANT. FIRST, TITLE VII OF THE 1964 CIVIL RIGHTS ACT WAS PASSED, PROHIBITING DISCRIMINATION ON the basis of sex, race, religion, and natianal origin. the wamen

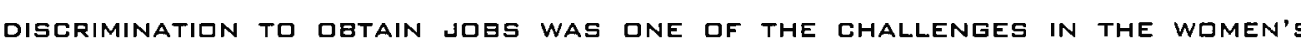
battle for equality (Mary J guhle and paul buhle 1978). gecand, the National grganization for WuMEN Was grganized, sogn to ge followed gy MANY OTHER MASS-MEMEERSHIP RRGANIZATIONS ADDRESSING THE NEEDS OF SPECIFIC groups of WIMEN, including blacks, Latinas, asian-AMERICANS, lesbians, WELFARE RECIPIENTS, BUSINESS IWNERS, ASPIRING PLLITICIANS, AND PROFESSILNAL WIMEN IF EVERY SORT. DURING THIS SAME TIME, THOUSANDS OF YUUNG WOMEN ON CoLLege campuses Were pLAYING ACTIVE ROLES WITHIN THE GIVIL RIGHTS MOVEMENT. AFTERWARDS, MANY OF THESE YOUNG WOMEN GEGAN FORMING THEIR OWN WOMEN'S

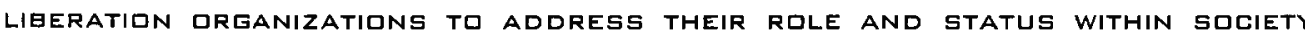
(MARY Jo BuHLe and Paul Buhle 1978 ).

SMALL GRDUPS OF WOMEN IN HUNDREDS OF COMMUNITIES IN THE UNITED STATES HAVE WORKED ON LARGE PROJECTS NOT ONLY ESTAGLISHING WOMEN'S SHELTERS GUT WOMEN'S NEWSPAPERS, BOOKSTORES, AND SMALL BUSINESSES. THEY HAVE CREATED GATTERED WOMEN'S SHELTERS AND RAPE CRISIS HOTLINES TO CARE FIR VICTIMS OF

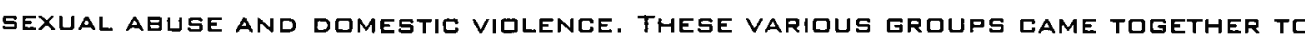
FIRM CHILDCARE GENTERS TO GIVE WOMEN A WAY TO WIRK OUTSIDE THEIR HIMES. WIMEN HEALTH CARE PRIFESSIONALS IPENED WOMEN'S CLINICS TO PROVIDE GIRTH CONTROL METHODS, FAMILY PLANNING COUNSELING, AND GFFER ABORTION SERVICES

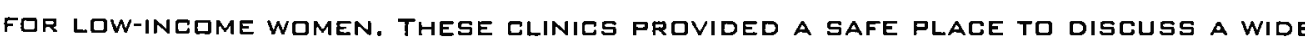
range of health concerns and experiment with alternative methods of PRENATAL CARE.
IN My Research I also found that TitLe IX of the Education Code of 1972 RULED EQUAL ACCESS TD HIGHER EDUCATION AND PROFESSIONAL SCHOLLS (GAVORA 2002). As a result, the number of female doctors, LaWyers, entineers,

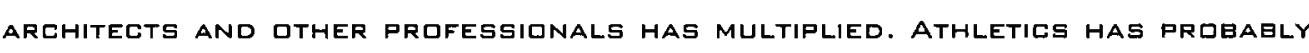

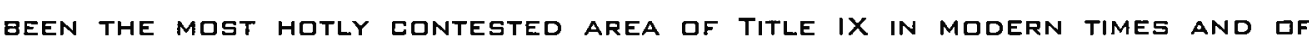
GREATEST IMPROVEMENT AS WELL. THE RISE IN GIRLS AND WOMEN'S PARTICIPATION IN ATHLETICS HAS BEEN TRULY EXTRAGRDINARY: ONE IN TWENTY-SEVEN HIGH SCHOLL GIRLS PLAYED GPORTS TWENTY-FIVE YEARS AGO; INE IN THREE DO TODAY. THE ENTIRE

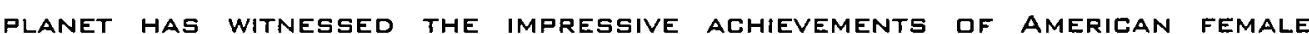
athletes in the glympic games of the LAst fEW decades--ANOther tangible RESULT DF TITLE IX (GAVDRA zOLZ).

THE WOMEN'S RIGHTS MOVEMENT has DTHER REMARKAgLE SUCCESSES THAT SHOULD

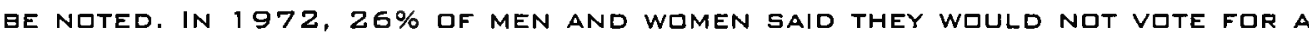
WOMAN For PREsident. IN 1996, that SENTIMENT had changed to APPROXIMATELY $5 \%$ OF WOMEN AND $8 \%$ GF MEN. THE AVERAGE AGE OF WOMEN WHEN THEY FIRST MARRY HAS MOVED FROM 20 TO 24 DURING THAT SAME PERIOD. BUT PERHAPS THE MOST DRAMATIC IMPACT OF THE WOMEN'S RIGHTS MOVEMENT of THE PAST FEW DECADES HAS BEEN IN THE ARENA dF FINANGIAL FREEDOM, WHIGH IS ONE QF THE MAJUR FACTORS INVQLVED IN DOMESTIC VIOLENGE. IT IS IMPGRTANT TD

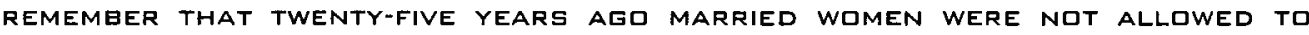
HAVE CREDIT CARDS IN THEIR OWN NAME, MOST WOMEN CQULD NOT GET A BANK LOAN WITHOUT A MALE co-SIGNER, AND WOMEN WORKING FULL-TIME EARNED ONLY 60 PERCENT OF MEN'S SALARIES For THE SAME TYPE OF WORK (MARY Ju BUHLE AND paul BuHLe 1978 


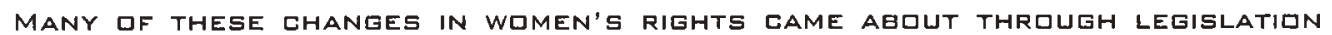
AND COURT CASES FOUGHT AND WON GY WOMEN'S GRGANIZATIONG. HOWEVER, MANY IF THE ADVANCES WOMEN ACHIEVED IN THE 1960s AND 1970 s WERE PERSINAL. fur example, wives gegan educating husgands to help them with the HOUSEWIRK IR REGULARLY TAKE RESPGNGIBILITY FIR FAMILY DUTIES TO ALLOW THEM

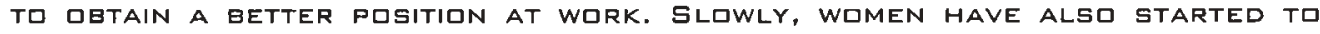
gain the financial freedom and emational strength to leave abusive HUSBANDS. SINCE THE 19705 THIUSANDS OF WIMEN HAVE TURNED TO SHELTERS AND CONTINUE STRUGGLING TO DETAIN AN EDUCATION AND THE RESQUREES FOR PEACEFUL LIVING (ShISTACK 2001).

TOday, young Wumen prqudly call themselves "the third waVe" as they CONFRONT NEW AND EQUALLY DIFFICULT ISSUES (FIGURE 7). WHILE MANY WOMEN MAY Still do nut want to ge called "feminists" due to negative reactions to the TERM, FEW WLULd GIVE uP THE LEgACy of PERSONAL fREEDIMS AND EXPANDED IPPIRTUNITIES WIMEN HAVE WIN OVER THE LAST 150 YEARS. QVER THE YEARS NOT INLY HAVE WOMEN WON THE RIGHT TO VOTE BUT THEY ARE BEING ELECTED TO PUELIC

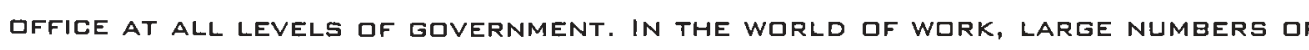

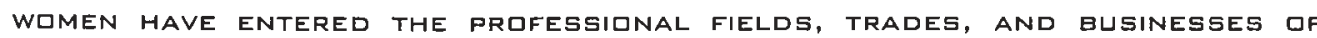

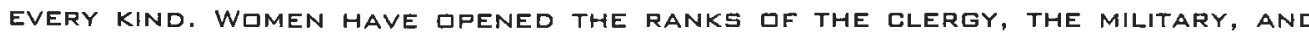

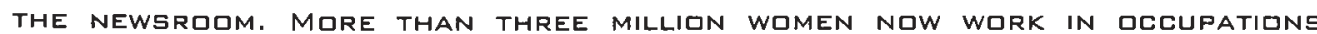
CONSIDERED TRADITIONALLY FIR MEN UNTIL VERY RECENTLY. THE THIRD WAVE OF WOMEN'S RIGHTS IS A EONTINULUS MOVEMENT TO STRENGTHEN WOMEN'S SLLIDARITY AND TO CONTINUE HELPING WIMEN IN NEED. INGOING INJUSTICES ARE BEING FQUGHT DAILY IN THE GLURTS AND SIGNIFICANT PRLGRESS IS BEING MADE.
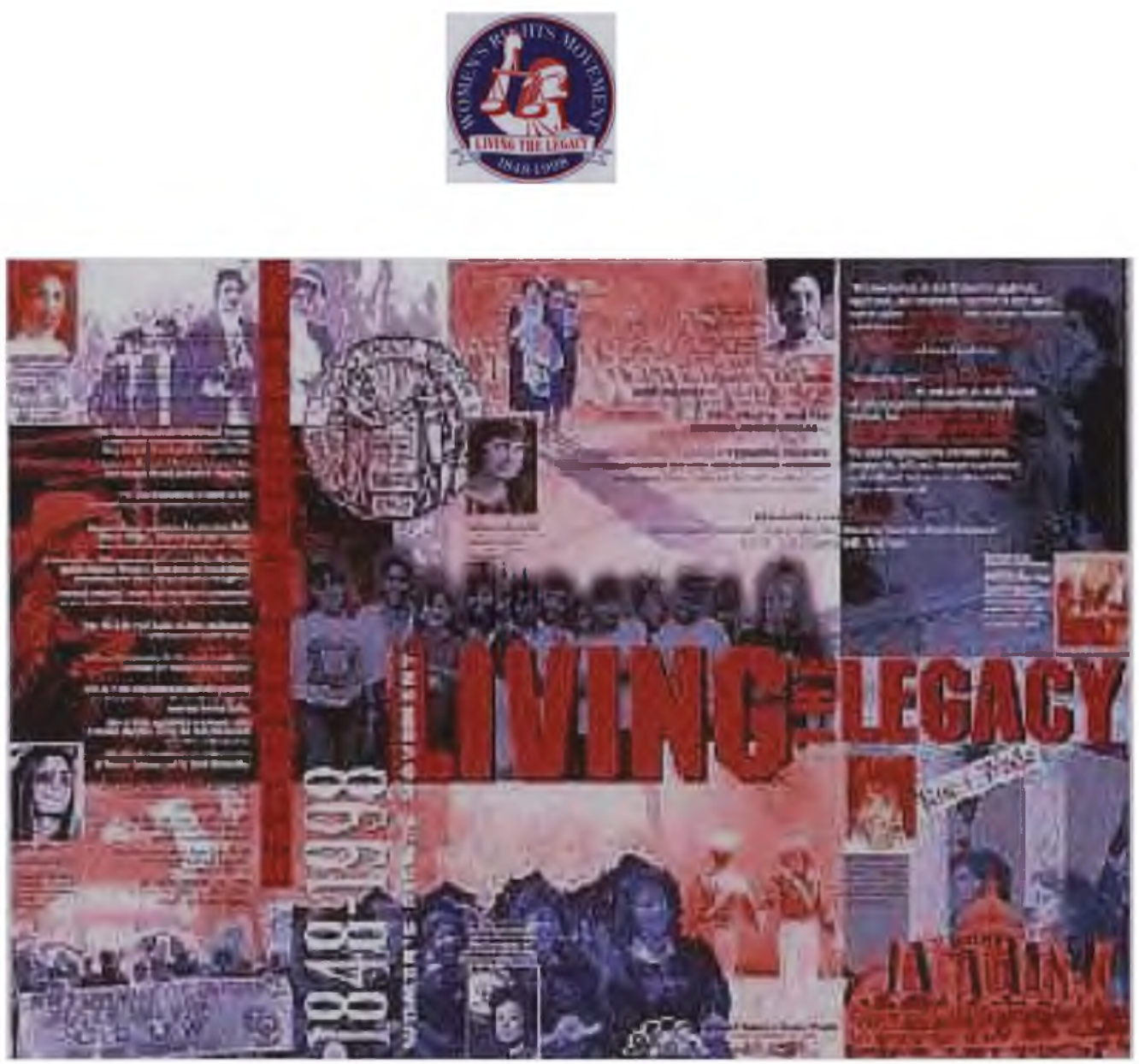

FIGURE

a 7 WOMEN's Rights Histarical Develapment Phatamantage 
"A SHELTEP IS A SANITUAPY WHEPE WIMEN WHO HAS SUFFERED LDSS DF SELF-ESTEEM AND SELF-CDNFIDENCE CAN FIND PEDPLE WHI APE EDMNITED TI REBUILD THE PDSITIVE SELF-IMAGE NECESARY FIR HER TO REISAIN EDNTREL DF LIFE."

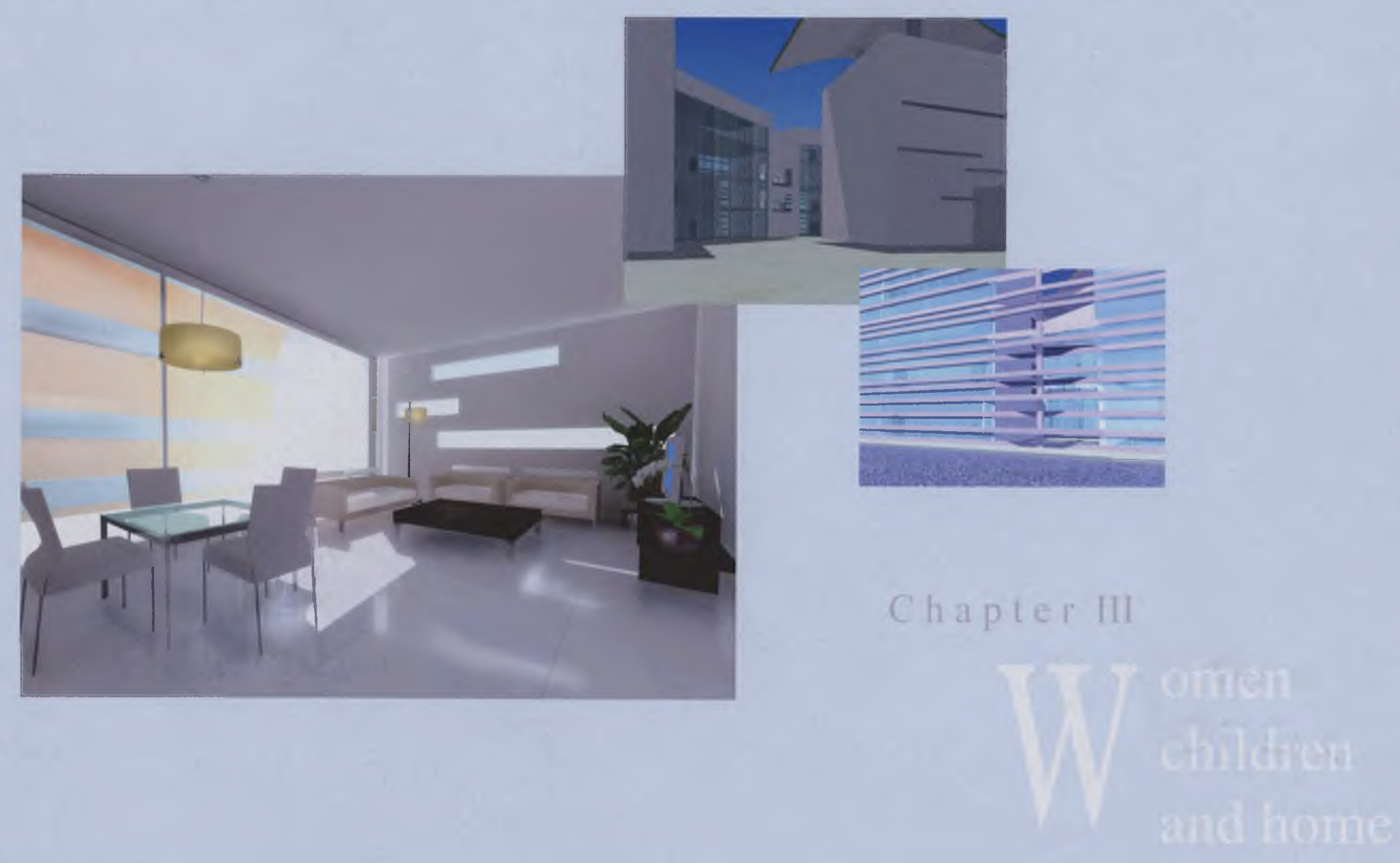


CHAPTER III

WDMEN, CHILDREN AND THE HOME

\section{A. Virlente against women}

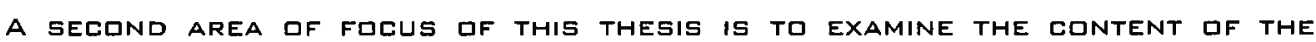
collective representations of "Wife abuse" and "Battered waman" and to ILLUSTRATE HOW THESE PARTICULAR REPRESENTATIONS FURNISH A MANDATE FOR THE PARTICULAR TYPE IF SOCIAL SERVICE PROVIDED BY SHELTERS. CERTAINLY THE LAEELS "Wife abuse" and "battered woman" have entered public consciousness. THEse issues are frequently addREssed in moVies, music, and theater, portraying the issue from different perspectives. The meaning of these LABELS AND THEIR CONTENT WAS A CENTRAL PART OF THIS RESEARCH.

WE HEAR THESE TERMS IN ARTICLES AND MASS PUgLICATIONS, IN PUBLISHED POLICY hearings, and trade juURnals for social service prgViders, though the FORM IF DISCQURSE DIFFERS ACCORDING TO THE WRITER AND AUDIENCE. gccasionally, wife aguse has been puglicly lageled as a women's issue. SUCH AN UNFAIR STATEMENT MAKES WOMEN TO KEEP WORKING WITH THE MATTER. IN past decades, mast publications on the subject Were trying to make young WOMEN MURE AWARE IF ISSUES. THIS HAS HELPED KEEP WIMEN ALERT AND MORE

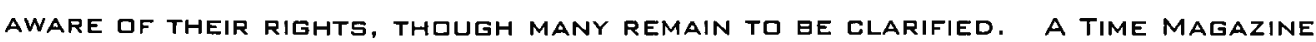
articles titLed “Wife geating” had the following to say an the issue:

“BUT A DOMESTIC SPAT IS NOT BATTERING, WHICH INVOLVES A PATTERN OF ESCALATING ABUSE IN A SITUATION FROM WHICH THE VICTIM FEELS SHE CAN NOT ESCAPE" (TIME 1992).

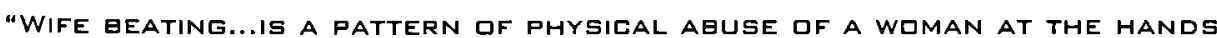
OF HER FORMER HUSBAND, OR MALE COMPANION. IT CONSISTS OF REPEATED GLOWS
WITH THE INTENTION OF INFLICTING HARM. IT IS MLRE SERIDUS THAN A MERE DISPUTE AND IT IS NDT A SINGLE SHOVE IR A SINGLE SLAP (FIELDS, 1995).

But, Who are exactly the persons that WiLl be living in the spaces to be CONSIDERED? FIRST IT IS IMPQRTANT TO MENTION THAT THE ABUSE OF WOMEN IS NOT LIMITED TO ANY SPECIFIC RACIAL, SOCIAL, CLASS OR ETHNIC GROUP. WOMEN CALLED UPON TO TELL THEIR STORIES IN PUgLIC HEARINGS haVE MADE IT CLEAR THAT MONEY

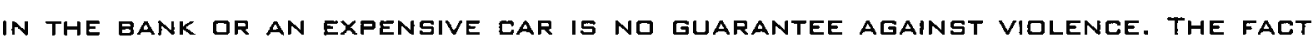
THAT AgUSE IS NOT LIMITED TO WOMEN WITH ANY PARTICULAR SET OF DEMOGRAPHIC characteristics has also brought particllar attention to EdUCATEd and AFFLUENT WHITE WOMEN WHO ARE EXPERIENCING THIS PROBLEM.

IN BRIEF, VIOLENCE AgAinst WOMEN IS ABOUT POWER AND CONTRGL. IT gCEURS WHEN A PARTNER, USUALLY A BOYFRIEND OR HUSBAND, ATTEMPTS TO CONTROL AND DOMINATE THE WOMAN. IT IS ALSO A CHOSEN ACTION AGainst A WOMAN, MOST OFTEN simply because she does ngt have the same physical strength as her

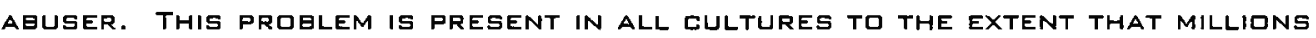

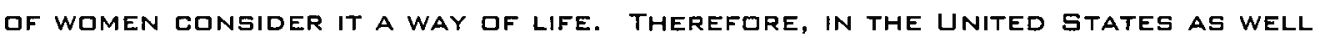
AS MANY OTHER COUNTRIES, THE LAW TREATS DUMESTIC VIOLENCE AS A CRIMINAL ACT AND A VIOLATION IF WOMEN'S RIGHTS.

throughout history men have made their own ghoice how to their

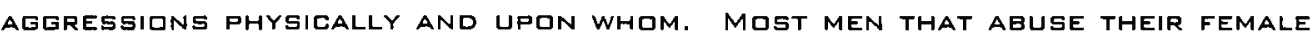

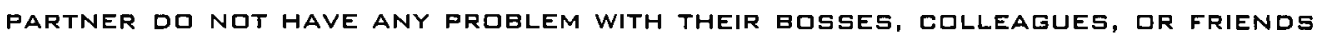

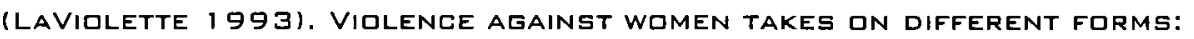

- Psyemglogical and emotional: threats, insults and degrading language can be just as damaging as physical abuse because they 
ENDANGER A WIMAN'S SELF-ESTEEM AND HER AEILITY TO CONTRIL HER OWN LIFE (LAVIOLETTE 1993).

- Social: this form of abuse occurs most offen in situations where a WOMAN IS KEPT TOTALLY DEPENDENT IN HER PARTNER AND ISLLATED FROM THE SUPPIRT OF OTHERS (LAVIILLTTE 1993 ).

- finangial: the woman is prevented from seeking employment, or is Not ALLOWED to haVe a gank ACCOUNT OR to KEeP ANY OF HER INCOME, SUFFERS FINANCIAL ABUSE. HAVING NO CONTROL OF MONEY KEEPS A WIMAN TOTALLY DEPENDENT AND MAY EVEN SUFFER PHYSICALLY GY BEING UNABLE TD SUPPLY HER IWN NEEDS (LAVIOLETTE 1993).

- Sexual: the woman is forced to perform or watch sexual acts WITHOUT HER CONSENT. CASES OF HUSBANDS RAPINE THEIR WIVES ARE A FREQUENT STATISTIE IN THE UNITED STATES (LAVILLETTE 1993).

- Physical: hitTing, pLNehing, slapping, kigking, gruising, breaking BONES, THRIWING GBJEETS, AND USING WEAPONS ARE GBVIOUS EXAMPLES OF PHYSICAL ABUSE. THE DENIAL OF HUMAN NEEDS, SUCH AS FOOD, WATER, SLEEP AND EVEN SHELTER ARE ALSD FORMS IF PHYSICAL ABUSE (LAVIOLETTE 1993).

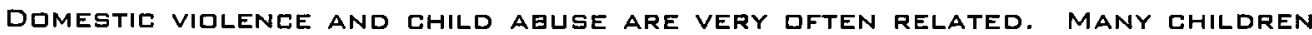
HAVE GEEN ABUSED IN ADDITION TO WITNESSING THE BATTERING OF THEIR MOTHERS. THESE CHILDREN ARE AT GREATEST RISK FDR DEVELOPING BEHAVIORAL AND EMOTIONAL DIFFICULTIES (HARMS 1998 ).

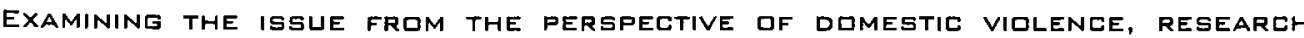
ESTIMATES THAT 45 TO 70 PERCENT OF WOMEN IN SHELTERS REPORT THAT THEIR CHILDREN haVe beEN AgUSED tod. THIS LINK BETWEen DOMESTIC VIOLENCE AND CHILD ABUSE PRESENTS A DOUBLE GIND FOR GATTERED WDMEN WHD, AS MOTHERS, ARE EXPECTED GY CUSTOM TO PROVIDE FOR THE SAFETY OR THEIR EHILDREN (HARMS 1998).
Oppression and Threats

*Controlling what she does, who

she sees, what she reads,

*Using jealously to justify actions

Treating her like a servant *Excluding her from all major decisions

*Being the one to define men's and women's roles

Emotional Abuse

*Putting her down

Making her feel bad about herself

*Making her think she is insane

POWER and CONTROL
Using Children

* Making her feel guilty about the children

*Using the childre

to relay messages

*Using visitation to harass her

*Threatening to take the children away.
Economic Abuse

*Preventing her from getting or keeping a job

Making her ask for money "Giving her an allowance *Taking her money

* Not letting her know about or have access to family income

\section{Intimidation}

*Making her afraid by using looks actions, gestures *Breaking things And destroying her property *Abusing pets or displaying weapons

\section{FIGURE}

口 g Characteristics df Damestic Vialence

\section{B. SHELTERS AS A REFUGE FRR WOMEN}

A SHELTER IS A SANCTUARY WHERE WOMEN WHO HAVE SUFFERED LOSS OF SELFEsteem and self-confidence can find pegple who are committed to

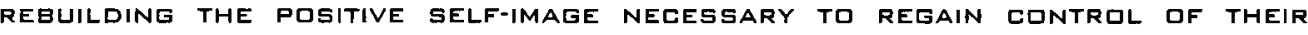
LIVES. THE LENGTH OF STAY IN A WOMEN'S SHELTER DEPENDS ON ITS AVAILABILITY AND ON HOW QUICKLY A WOMAN CAN FIND HER OWN HOUSING. MOST WOMEN GRING their children With them. Research indicated that the aVerage number of GHILDREN WOMEN GRING WITH THEM TO SHELTERS IS TWO THOUGH IN SOME CASES THE NUMBER MAY BE AS HIGH AS SIX USUALLY, EAEH SHELTER HAS ITS OWN SUPPORT 
stafF AND ADMINISTRATORS. DURING THE DAY THERE ARE COUNSELGRs, STAFF MEMBERS AND VOLUNTEERS THAT CAN PROVIDE GUIDANCE IN FINANCIAL MATTERs, legal aid, hqusing information, and career planning. At night some staff

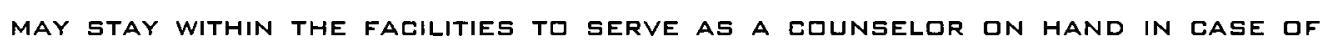
EMERGENCIES (MARTIN 1977 ).

"A shelter can be a place where a woman who has lived in fear and ISOLATION DAN FIND SECURITY AND SAFETY AS WELL AS THE LOVE AND SUPPORT OF OTHER WOMEN".

JeNNIfER BAKer Fleming, StOPPING Wife abuse

"MOST BATTERED WOMEN IN ORDER TO LEAVE VIOLENCE PRIMARILY NEED SAFETY AND SUPPORT. THEY FEEL ISOLATED AND DEPENDENT AND BLAME THEMSELVES. THEY NEED RECOGNITION THAT THEIR EXPERIENCE IS SHARED AND THAT THEIR PROBLEM IS SOCIAL AND PQLITICAL, NOT INDIVIDUAL".

gail sullivan AND JaNe WeIss, how We gupport battered Women

THE pReceding discussion regarding the situations that abused wamen COMES ACROSS WHILE TRANSITIONING INTO A SHELTER IS RELEVANT TO UNDERSTANDING THE PROGRAM DESIGN. THE gPACES IN A SHELTER ARE AN INTEGRAL

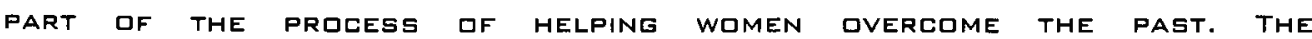
characteristics of the spaces Will ge EXPLAINed in further detail in the FOLLOWING PAGES.

A WIMAN THAT REQUESTS SHELTER IS MAKING HER DECLARATION OF INDEPENDENGE FROM AEUSE. A WOMAN WHO ENTERs A SHELTER MAY BE EUPHORIC AS A RESULT IF ACHIEVING LIBERATION FROM YEARS IF VIOLENCE AND DPPRESSION. IN SOME CASES, WHEN A WOMAN LEAVES HER hIME hER TROLGLES MAY ACTUALLY WIRSEN IF SHE IS Nat in the right place. The shelter needs to be designed to assist Wamen SUFFERING FROM STRESS AND DEPRESSION, AND MUST DFFER MORE THAN JUST
EMERGENCY HOUSING. WHAT IS ACCOMPLISHED GY SIMPLY PROVIDING A SMALL RODM

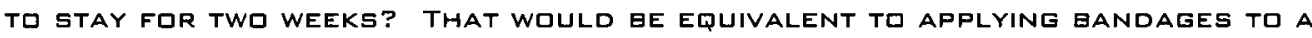
WOUNDED SOLDIER AND SENDING HIM gACK INTO gATTLE. THE POINT OF THIS IS THAT SHELters SHOULd NOT BE Simply REsidentes. SHELTER facilities must Be SUITABLE FOR PROVIDING ASSISTANCE EFFICIENTLY, AND ADVANCE THE PROCESS OF CHANGING WOMEN'S LIVES. THEREFORE, THE MOST IMPORTANT SERVICES WOMEN NEED ARe counselors, Nutritionists, laWyers, psychalgGists, housing, health CARE, CLASSRIOMS, AND SUPPURT WITH CHILDREN.

As mentioned earlier, sHelters around the country haVe tWo service guals. first, affering a secure place from vidlent men. Sectnd, agting as a STEPPING-STONE INTO WOMEN'S INDEPENDENGE AND WELL BEING. AS SUCH, THE STRATEGIES FOLLOWED IN THIS THESIS WILL FOLLOW ALL THE MENTIONED SERVICES COMBINED IN A LIVING ENVIRONMENT IN WHICH WOMEN CAN EXPERIENCE A FULL SENSE OF SECURITY AND SUPPORT.

two additional key ideas were taken into gonsideration. These are INDIVIDUAL RESPGNGIGILITY AND COMMUNITY RESPONGIGILITY, WHICH DEFINE THE

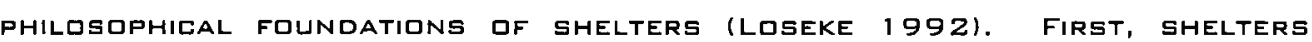
OFFER COMMUNAL LIVING, AND IT IS THIS COMMUNITY OF WOMEN THAT CONSTITUTES THE SINGLE MOST IMPIRTANT INGREDIENT OF SHELTER SERVICE SUCCESS.

WHEN A WOMAN FIRST COMES IN CONTACT WITH A SHELTER, THE MIST REFRESHING AND POWERFUL ASPECT OF THE ENCLUNTER IS THAT SHE IS VALIDATED AND GIVEN A place to live. She may experience a tremendqus sense gf relief, privacy, 
AND EMPQWERMENT. SElf-help is the fundamental principle of shelter ORGANIZATION (LOSEKE 1992 ).

THE IDEA IF COMMUNITY IS VERY UNLIKE A HOTEL WHERE GUESTS OCCUPY PRIVATE ROOMS AND MOST DFTEN REMAIN STRANGERS TO INE ANOTHER. THE SHELTER DESIGN IS MIRE LIKE A SORIRITY HQUSE WHERE MEMBERS SHARE PUBLIC SPACES AND WHERE SATISFYING FACE-TO-FACE INTERACTION IS POSSIBLE NOT ONLY BECAUSE THEY SHARE SPACES BUT EXPERIENCES AS WELL. COMMUNAL LIVING SHOULD GE STRUCTURED TO

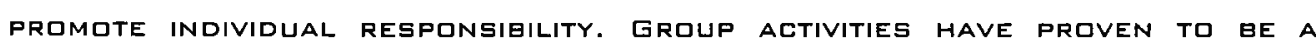
PQSITIVE WAY GF ENCQURAGEMENT (LOSEKE 1992). GROUP MEETINGS ARE ACTIVITIES IN WHICH WOMEN CAN DISPLAY THEIR COMPETENCE TO OTHERS AND THUS INCREASE their self-esteem. They are, in other words, constructed as a way to achieve service goals since WHEN WOMEN take the initiative. THEy begin to DEVELIP A SENSE of CAPABILITY AND CONFIDENCE, WHIEH IS DNE OF THE MOST Valuagle resturees a shelter can deliver.

THE COMMUNAL ENVIRONMENT CQUNTERACTS THE ISOLATION A GATTERED WOMAN HAS EXPERIENCED, AND CLOSE LIVING WITH OTHER WOMEN ENGQURAGES THEM TO SHARE their experiences. Furthermore, according to LOSEke, the dNGoing CONVERSATION AMONG WOMEN LIVING TOGETHER IN A SHELTER ENCQURAGES THEM TO EXPRESS THEIR ANGER AND DENIALS. FUR THE VIOLENCE THEY HAVE EXPERIENCED, AND QVERCDME FEELINGS IF GUILT AND INADEQUAEY. THUS, SHELTERS AFFORD PEER SUPPORT AMONGST WOMEN, WHICH EAN REPLACE TRADITIONAL PSYEHOTHERAPY. THIS SUBSTITUTION CLAIM HAS BEEN BORNE OUT IN REAL-LIFE EXPERIENCE BY CLIENTS WHO DISCGVER OTHER WOMEN WHO HAVE SHARED THE SAME EXPERIENCES AND EMOTIONS, SINCE WOMEN HAVE THE SKILLS NECESSARY TO BE SUPPORTIVE LISTENERS. IN BRIEF,
SHELTERS ACCOMPLISH THEIR SERVICE GLALS PRIMARILY BY ALLOWING BatTERED WOMEN TO LIVE AMONGST EACH OTHER (LOSEKE 1992 ).

in SUMMary, the shelter design goal is to provide spaces that can TRANSFIRM A BATTERED WOMAN INTO A STRONG AND INDEPENDENT WOMAN THAT IS CAPABLE, BOTH PHYSICALLY AND EMOTIONALLY, TO VIGOROUSLY CONTINUE GUILDING her life. Within this framework, WOMEN With children estaglish the ENVIRONMENT ACCORDING TO THEIR SURROUNDING SPACES; THEY ACGOMPLISH EVERYthing themselves and through this EXPERIENCE they can became capable df living within a facility that offers privacy and a sense of COMMUNITY. THE FACILITIES MUST PROVIDE SPACES FaR GROUP GOUNSELING, WHIEH HAS PROVEN EENEFITS. WITHIN THESE ROOMS WOMEN LEARN POWERFUL PRINCIPLES, SHARE EXPERIENCES AND HAVE SUPPORT FROM EACH OTHER. HAVING SPACES TO SHARE NON-JUDGMENTAL, EMPOWERMENT-BASED COUNSELING AND SUPPIRT GROUPS HELP NOT INLY TO IDENTIFY AND UNDERSTAND THEIR PROBLEM BUT ALSO EDUCATE THEM TO RESPECT AND LOVE THEMSELVES.

IN ADDITION TO THE IDEAs PRESENTED EARLIER, DR. VERDERVER's SKETCHES ARE ALSO TAKEN IN CONSIDERATION. A BRIEF DISCUSSION OF EACH SKETCH POINTS OUT THE IMPORTANCE of THE IDEAs PRESENTED IN THIS THESIS. EACH SKETCH POINTS gut an important Variagle of shelter design. For example, the NEIGHBORHOID ANALYSIS POINTS GUT THAT THE BUILDING SHOULD NOT BREAK FROM ITS SURRIUNDING CONTEXT, BUT IF IT DOES, IT SHOULD BE CLOSE TO A POLICE STATION. THE SKETCHES ARE SELF EXPLANATORY AND STRAightFGRWARD. 


\section{NEIGHBORHOOD ANALYSIS}

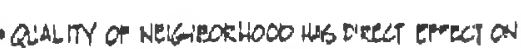

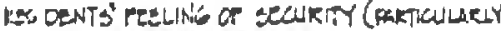

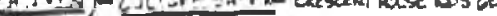

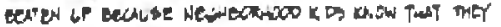

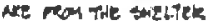

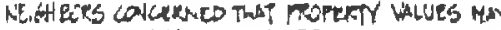
DePLATE ECLASES O SNELTER

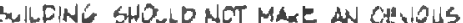

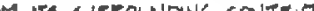

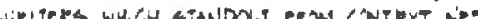

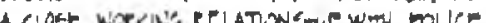

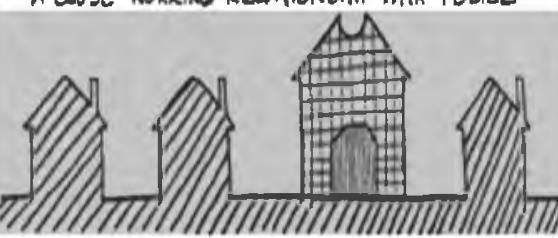

Figure

口 9

IDEAL LOCATION FIR SHELTERS

\section{FREEDOM OF CHOICE}

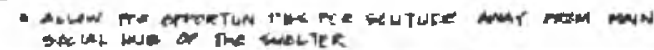

\begin{tabular}{|c|c|}
\hline FIGURE & \\
\hline 11 & FREEDOM OF CHOICE \\
\hline
\end{tabular}

\section{CONTINUM OF SOCIAL INTERACTION}

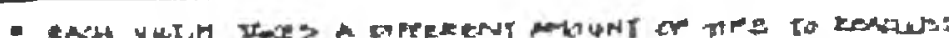

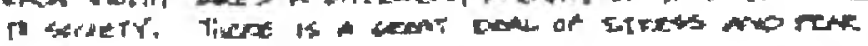
indivite.

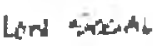

riTERTi

Higne extint INTSEATIIN

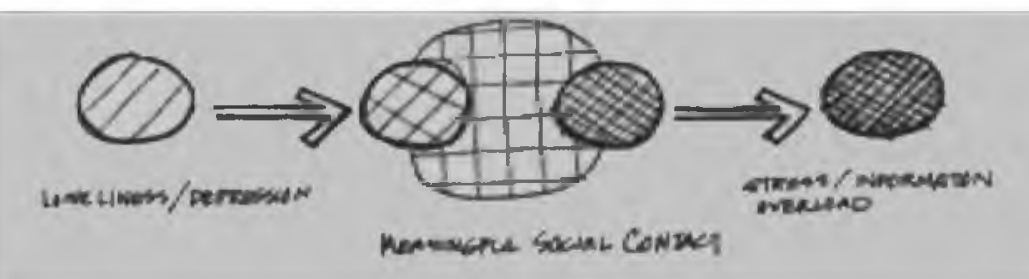




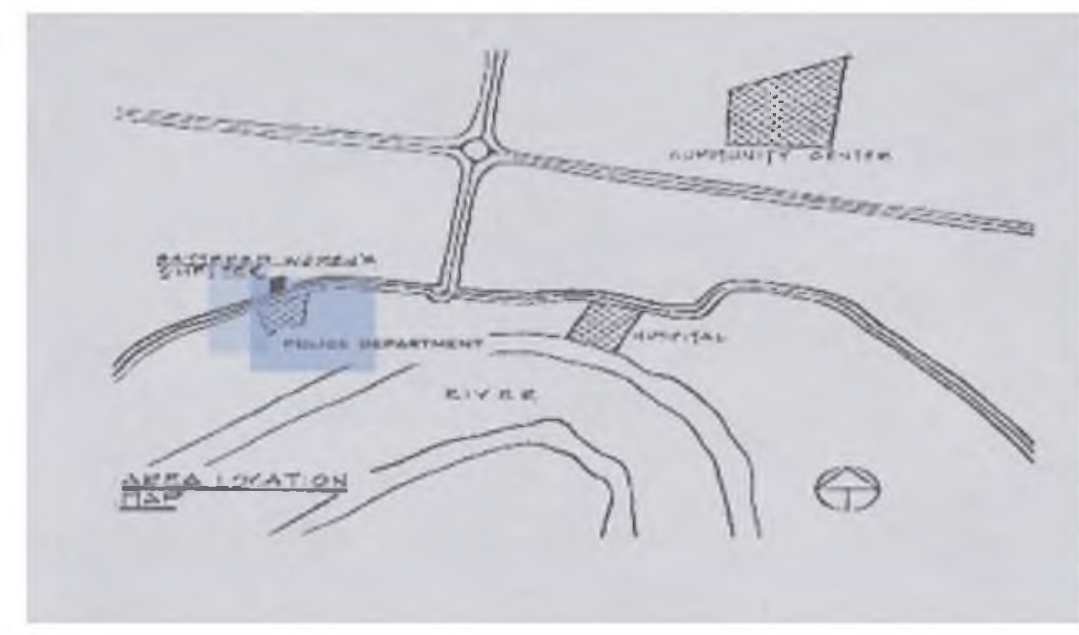

FIGURE

I 3 NEIGHETRHOLD ANALYSIS

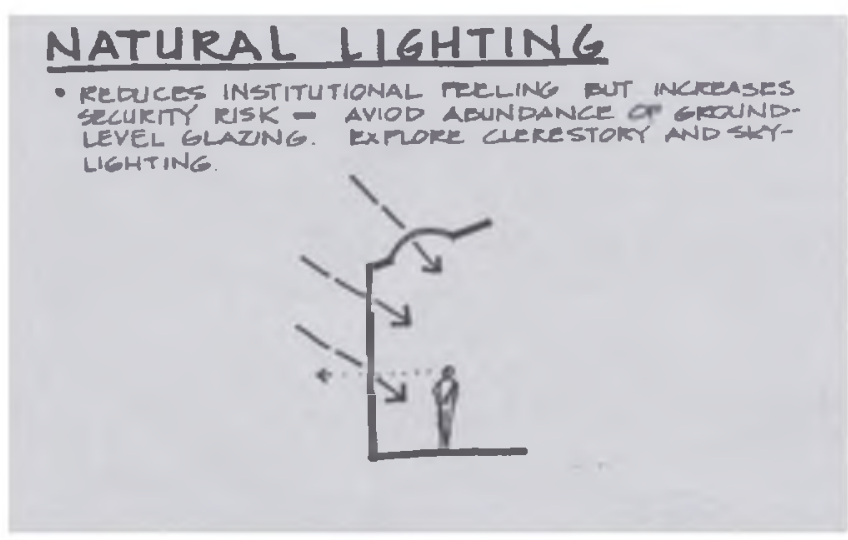

FIGURE

4 Natural Lighting in ghelters

c. PREgerving CHILDHOLd IN SHELTERS

"THOUSANDS OF CHILDREN WITNESS DOMESTIC VIOLENCE WHEN THEIR MOTHERS ARE BATTERED. SDMETIMES THE CHILDREN THEMSELVES ARE PHYSICALLY ABUSED; MORE IFTEN, THEY ARE EMOTIONALLY AND PSYCHOLOGICALLY ABUSED-SIMETIMES FOREED TO WATCH THEIR MOTHERS BEING BEATEN" (HARNS 1998),

“HQMELESS CHILDREN EXPRESSED CERTAIN PLEASURES THAT WERE REPEATED QVER IN THEIR CONVERSATIONS. MAKING FRIENDS WITH DTHER CHILDREN IN WHOM INE COULD CONFIDE, SHARE COMMIN INTERESTS, AND PLAY WITH WAS SEEN AS A CIMFORT AND DELIEHT" (HEUSEL 1995).

"SHELTERED CHILDREN, WHOSE PREVIOUS EXPERIENCE HAD BEEN FULL OF FAMILY CONFLICT OR NEIGHBORHOQD VIOLENCE, KNEW AND ACKNOWLEDGED THAT LIVING IN THE STREETS DR AT THE SHELTER WERE SYNONYMOUS WITH BEING HOMELES5." "THEY HAD BEEN TAUNTED FOR LIVING THERE. AND, WERE EMBARRASSED, SAD, AND FEELING PROR" (HEUSEL 1995).

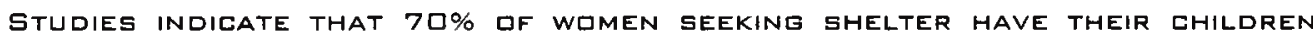
WITH THEM, AND $17 \%$ dF these have three dR MgRe (MCKay 1994). SUCH A STATISTIC MAKES IT ELEAR THAT THE INCLUSION OF CHILDREN MUST BE INCLUDED AS A SIGNIFICANT FACTOR IN THIS THESIS. FIR CHILDREN ENTERING SHELTERS, THIS MAY BE A SIGNAL OF THE DISINTEGRATION OF THEIR FAMILIES, DR A SEPARATION FROM THEIR NEIGHBORHOLD, THEIR SCHOLL AND/OR THEIR FATHER. THESE CHILdREN SUFFER FROM STRESSES SIMILAR TO THEIR MOTHERS. THEY MAY HAVE BEEN TARGET gF EHILD ABUSE (HARNS 1998). IN SOME CASES WHILE MOTHERs ARE IN CRISIS, their relatidnships With their children may change. THEREFare, the ghelter

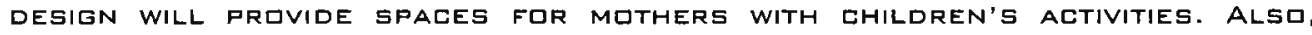
CHILDREN NEED THE IPPORTUNITY TO HAVE THEIR IWN SPACE TO REST, TO ASSESS THEIR SITUATIONS AND TD DEVELOP A PHYSIOLOGICAL SENSE OF SAFETY WITHIN THEIR

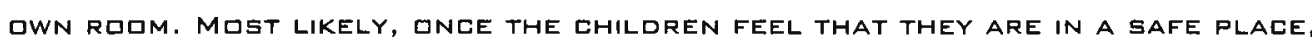
THEY CAN OVERCOME THE PHYSIGLGGICAL EFFECTS OF BATTERING (HARNS 1998).

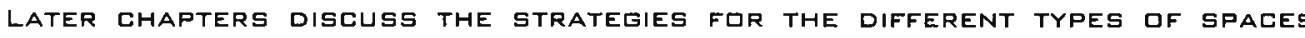
NEEDED IN THE BUILDING. 
ANOTHER STUDY GY HOUSEL IN 1992 FOCUSED ON CHILDREN'S PERSPECTIVES ON

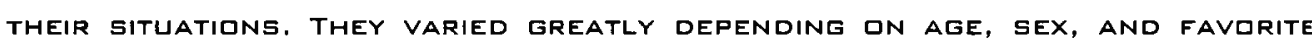
DIVERSIINS, AND PROVIDED AN UNDERSTANDING OF CHILDREN's DESIRES FIR certain qualities in spaces. HaUsel's study ReVEaled that ane third of the children Wished for material things and achievements. THEIR Dreams INCLUDED HAVING A HAPPY HOME AND HAVING THEIR IWN ROOM. A NINE-YEAR-OLO GIRL SIMPLY WISHED FOR NICE THINGS FOR HERSELF AND HER MOM. ONE BOY EMPHASIZED hIS LONGING fOR A HaME IN hIS DREAMs (HARNS 1992). THEse DESIRES EXPRESSED BY THE CHILDREN PRIVIDE THE CINCEPTUAL FRAMEWIRK FIR THE CHILDCARE CENTER AND RESIDENEES.

CLEARLY, THE RESEAREH IN GHILDREN PRQVIDEs A GQQD IDEA OF THE QUALITY OF spaces for GHILdRen in the shelter. Again, the answer goes to the same

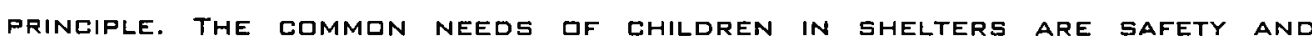
SECURITY. SOME GHILDREN ARE MIRE SENSITIVE DURING THE STAGE IF LIVING IN A SHELter. THEY MAY FEAR THE DARK, THE STRANGERs, AND fEAR IF gEING GUTSIDE THE HOME (HARNS 1994). ANOTHER COMMON NEED OF CHILDREN IS EMOTIONAL SUPPORT AND counseling. CIUNSEldRs use their time helping childoren IDENTIFY THEIR FEARS AND UNCERTAINTIES. FUR THAT REASON, THE CHILDREN'S HELP STAFF MUST HAVE THEIR IWN SPACES TO TAKE CARE OF EACH CHILD INDIVIDUALLY AS WELL AS IN A GROUP SETTING. DURING GROLP COUNSELING, CHILDREN ARE GFFERED A WAY TO IDENTIFY FEELINGS AND DEAL WITH FEARS, GUILT, AND CONFUSION. IT MUST BE A SPACE OF COMFORTABLE SITTING AREAS AND A NON-DISTRACTING ENVIRINMENT. THEREFORE, THE GHILDREN'S CIUNSELING ROOM MUST ge A SAFE ROIM NEAR THE playground so after counseling, the children can gather and play as a GRIUP.

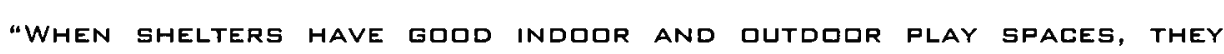
CONVEY THE MESSAGE THAT THEY ARE READY FDR CHILDREN AND UNDERSTAND WHAT THEY NEED. IF THE PLAY SPACES ARE SLPPERVISED BY STAFF, THE MESSAGE IS THAT THE SHELTERS CARE ABQUT CHILDREN'S DEVELOPMENT AND ARE GIVING THEM THE SAME PLAY DPPORTUNITIES THAT OTHER CHILDREN HAVE IN SCHODL AND CHILDCARE" (HARNS 1998 ).

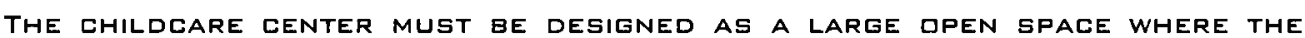

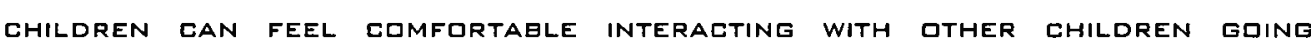
through the same difficulties. Thus, a terrace was designed on the third flogr as a large open space that serves as aN qutdogr play area. It is a SPAEE THAT EXPRESS SAFETY SINCE IT IS SURROUND GY THE ENELDSE WALLS OF THE BUILDINGS.

ONCE AGAIN DR. VERDERVER'S SKETCHES WERE INCLUded IN THIS PART DF THE RESEARCH. THESE EMPHASIZE THE CHILDREN'S SAFETY AND BUILDING LOCATION considerations for the same reason. As the drawings explain, the CHILDREN'S QUTDOLR PLAY AREA MUST BE LGCATED IN A SAFE AND PROTECTED AREA. Also, resident parking must ge located adjacent to the living facilities. THESE SKETCHES ONLY PARTIALLY REFLECT CHILDREN'S SAFETY CONSIDERATIONS.

IN SUMMARY, THE THREe BASIC ELEMENTS TO KEEP IN MIND IN RENDERING the DESIGN ARE PROTECTION, SUPPORTIVE RELATIONSHIPS, AND APPROPRIATE PISITIVE

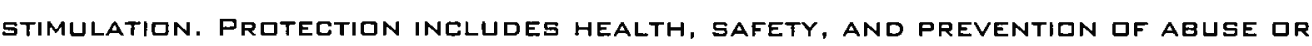
neglegt. ingluding these three elements in the design will allow the facility to Become a place df true shelter. THE designed guilding Will have

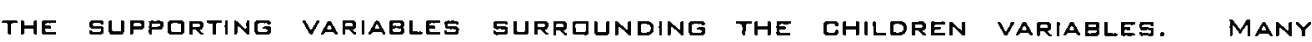
ENVIRONMENTAL AREHITECTURAL CONCEPTS SUCH AS sPACE, PRIVACY, AND SUPPIRT NETWORKS ARE MEANINGFUL TO CHILDREN AS I DISCOVERED IN THE VERBALIZATION OF 
THEIR FEELINGS IN THE COURSE QF MY RESEARCH INTO THE PLIGHT IF CHILDREN IN SHELTERS. THE IMPACT OF SHELTER LIVING ON LATENCY AEE CHILDREN IS EITED IN LITERATURE (WALSH 1990$)$.

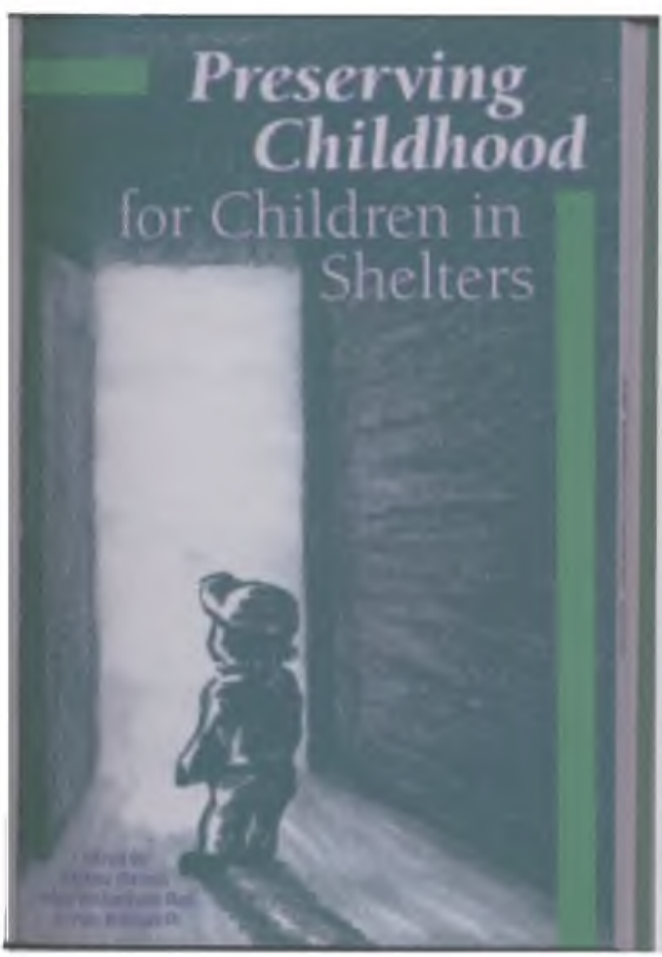

\section{CHILDREN'S OUTDOOR PLAY AREA}

- akrahee so that childoken can pur rreger curcrams

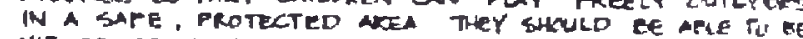

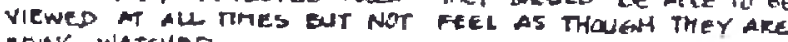

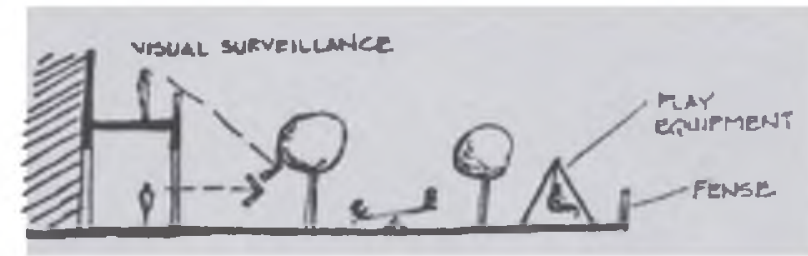

FIGURE

16 CHILDREN QUTDQRR play area

\section{RESIDENTS PARKING}

- residents pear that huseands mar stot car-

PARKING NEeDS TO de concelaLeD

- MOST RESIDENTS DO NOT HAVE ches ca canNot

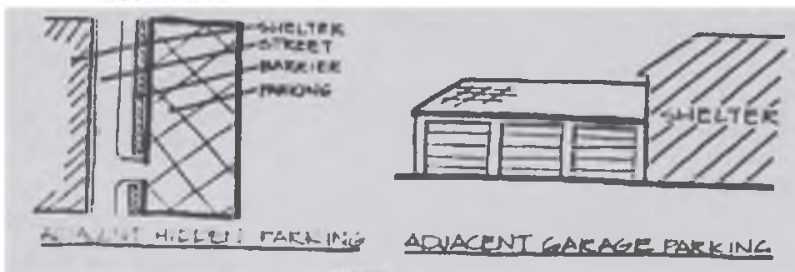

- shelter should de within two acks o eurs stop because most women don't mave

FIGURE

17 RESIDENTS PARKING 


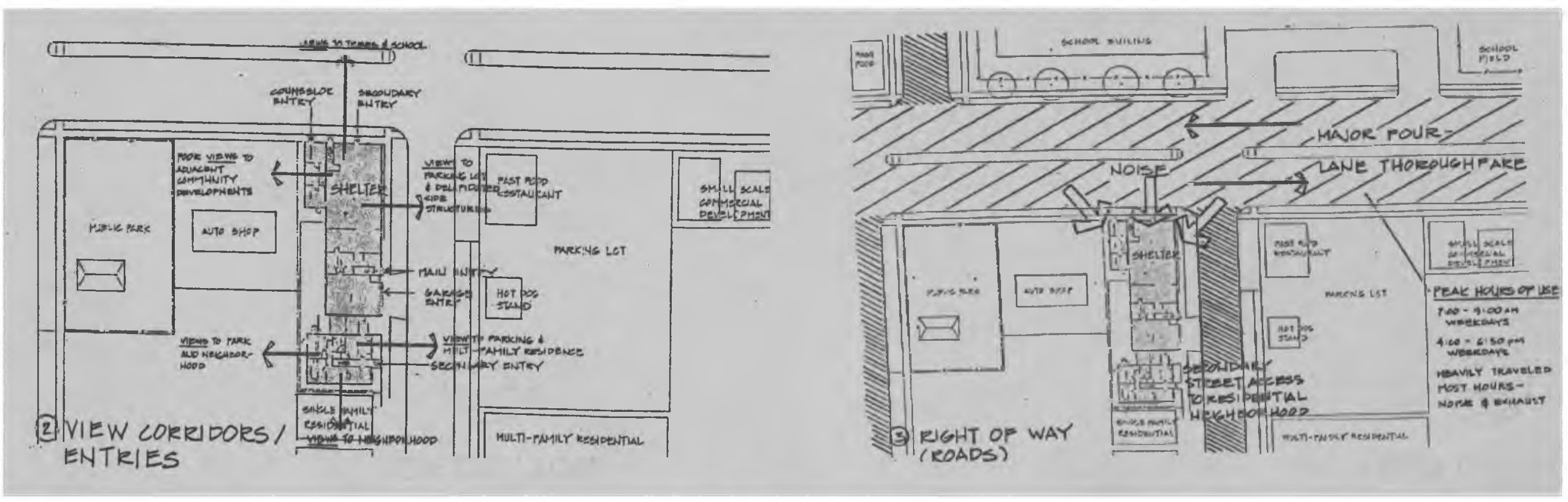

FIGURE

\begin{tabular}{ll}
18 & CIRRIDORS AND ENTRIES, DIAGRAM \\
\hline
\end{tabular} 
AGAPE WIMEN SHELTER . YMLA WIMEN SHELTER . ALEXANDRIA WDMEN SHELTER

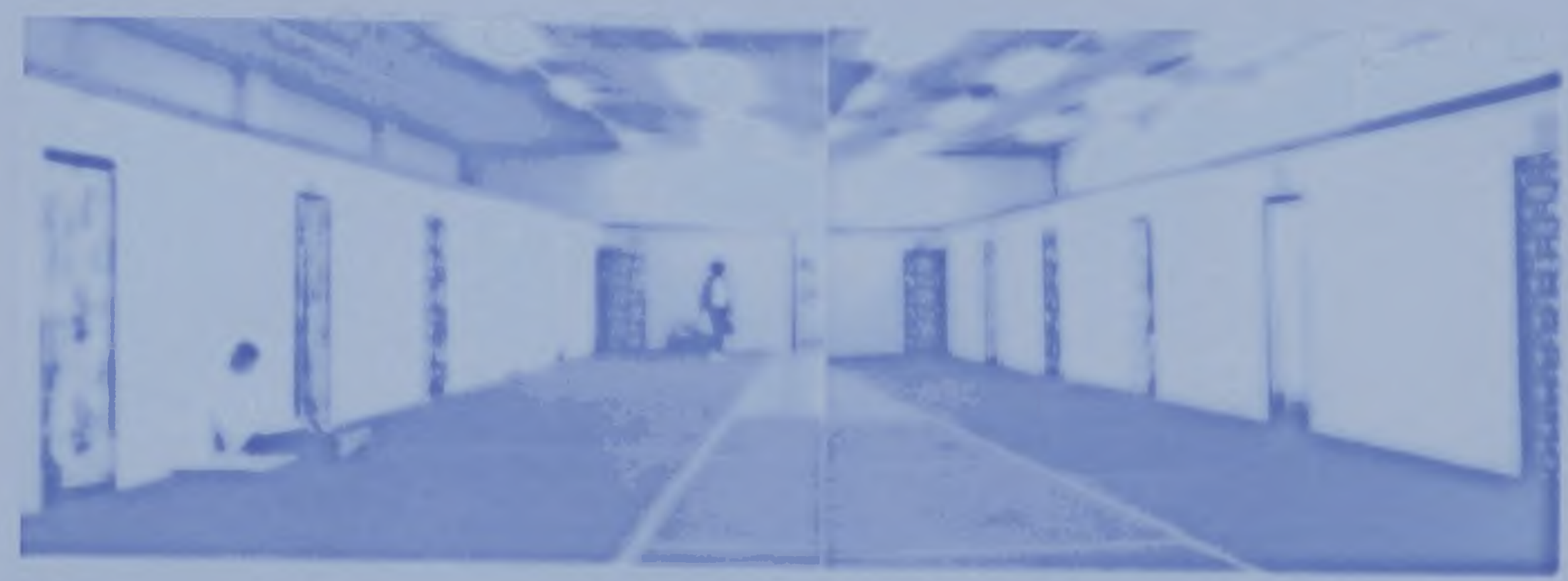

Cha pler IV 
CHAPTER IV

CASE STUDIES

a. case study a.

Agape WoMen's MiNistries in HaMestead, Florida

THIS SHELTER, AS SHOWN IN FIGURE 23 , PROVIDES SERVICES FOR WOMEN IN SOUTH

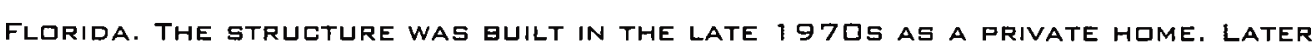
IT BECAME A WOMEN'S CENTER BY ADDING TRAILERS TO PROVIDE SHELTER FOR WOMEN IN NEED. IN THE MAIN BUILDING, THE INTERIOR WAS IN SHOCKING CONDITION: AND THERE WAS WOEFULLY INSUFFICIENT QFFICE SPACE FOR GQUNSELORS AND STAFF. THE RESIDENTIAL UNITS WERE SHARED TRAILERS THAT CONNECTED TO EACH OTHER BY AN elevated wodden walkway (See figure 23). in addition, due to the high DEMAND FIR RESIDENCES, THE ROIMS WERE SHARED GY MORE THAN INE FAMILY, FREQUENTLY CREATING A VERY TENSE ENVIRONMENT AND LAEK IF PRIVACY. THE MIST IMPIRTANT EONSIDERATIONS IN A SHELTER WERE ALL MISSING IN THIS GUILDING, namely: privacy, safe lgcation and support services. The fact that this SPECIFIC SHELTER DID NOT ADDRESS THESE VERY BASIC LONSIDERATIONS MAKES IT A PERFECT CASE STUdY fLR this thesis.

CLEARLY, SECURITY IN THIS gUILDING WAS ALMOST TOTALLY LACKING; ANYONE CQULD ENTER THE gUILDING DUE TO THE ABSENCE of FENCING, gates AND/OR A SECURITY gfFicer in the Main entrance. Furthermare, there Were No interior spaces WHERE THE CHILDREN CQULD MEET TO INTERACT. AS WE SEE IN FIGURE 24, THE MAP SHOWS THAT THE SHELTER IS VERY FAR FROM SCHOOLS, POLICE DEPARTMENTS OR ANY OTHER ENTITY QR FACILITY THAT COULD HELP WITH THE EVERYDAY NEEDS FOR THE WIMEN AND CHILDREN. A PROBLEM OF PARTICULAR CONCERN IS CREATED BY

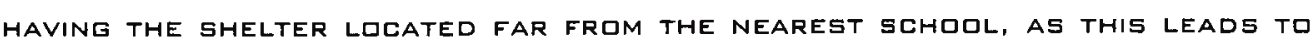

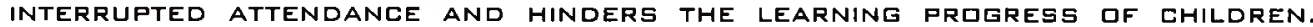
HOWEVER, NEW INSTALLATIINS AT THIS FACILITY WILL ALSO SERVE AS A REASINAGLE CASE STUDY FOR THIS RESEARCH. agape Women's Ministries Existent facilities

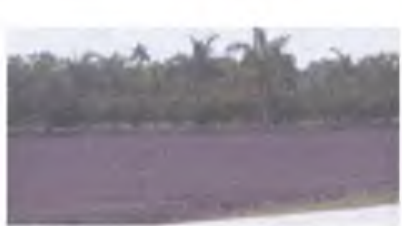

FIGURE 21

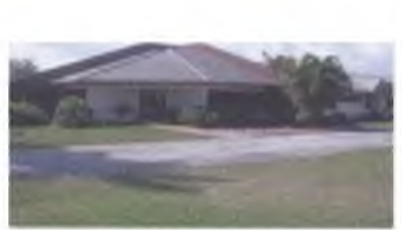

FIGURE $2 Z$

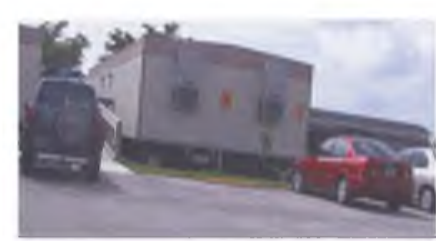

FIGURE 23

\begin{tabular}{|c|c|}
\hline FIGURE & \\
\hline $2 \square$ & AGAPE SURRIUNDING SITE \\
\hline 21 & MAIN BUILDING GF AGAPE WOMEN'S MINISTRIES \\
\hline 22 & RESIDENCES OF AGAPE WOMEN'S MINISTRIES \\
\hline
\end{tabular}

The new propgsal for the agape Women's Ministries in Homestead is a TYPICAL FLORIDIAN ARCHITECTURAL DESIGN THAT WILL SERVE AN AVERAGE DF SIXTEEN WOMEN. TWO RESIDENTS WILL SHARE EACH HOUSING UNIT COMFORTABLY (SEE FIGURE 23). THE ADMINISTRATION AND SUPPORT SERVICE IS THE FRONT BUILdING AND the REAR BUILDING IS THE CHILDCARE CENTER. THE LAYOUT APPEARS LOMFURTABLE AND FLEXIELE BUT THE DESIGN FAILS TO ADDRESS SOME SECURITY CONTROL ISSUES. 


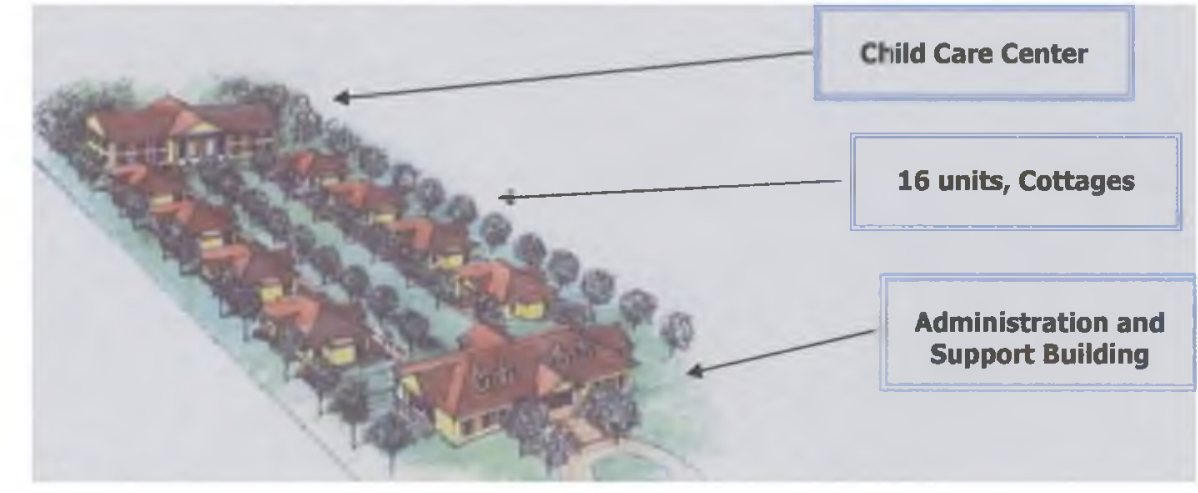

FIGURE

23 Agape Shelter, New facilities

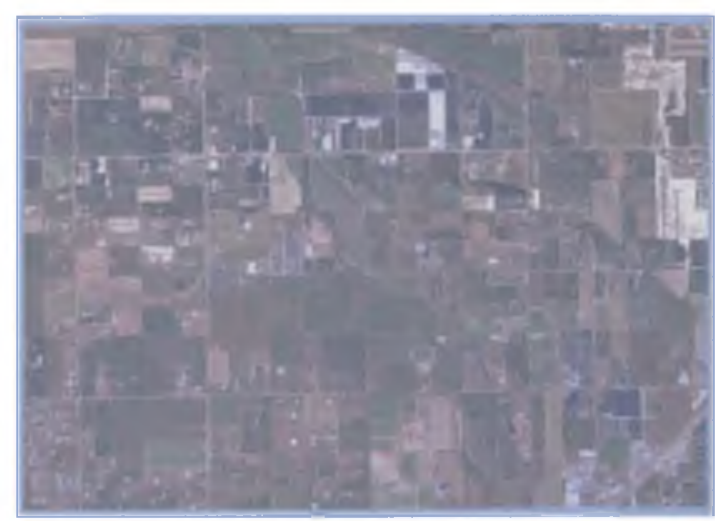

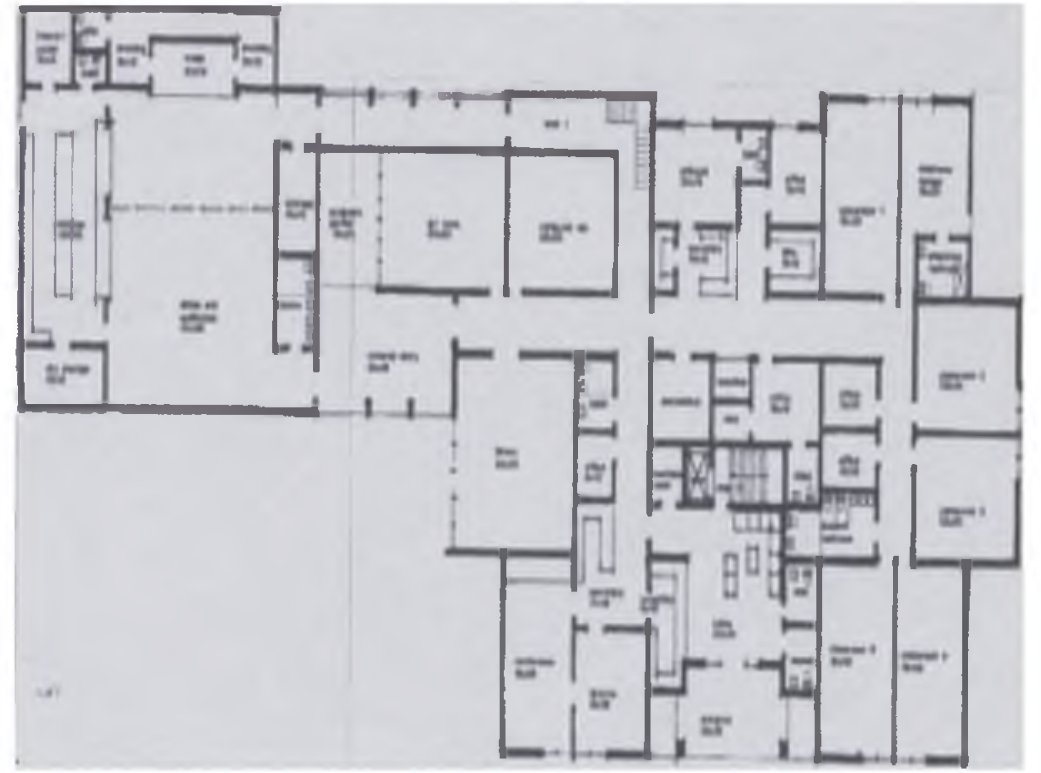

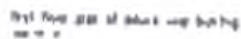

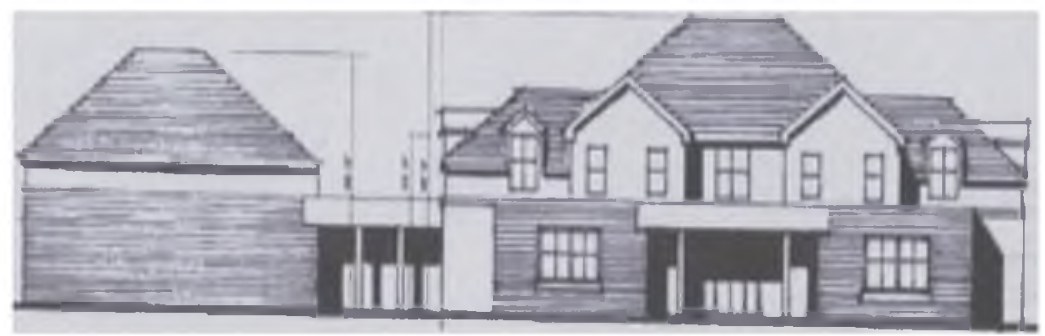

FIGURE

25 agape shelter, New facilities, Plan and Elevation 


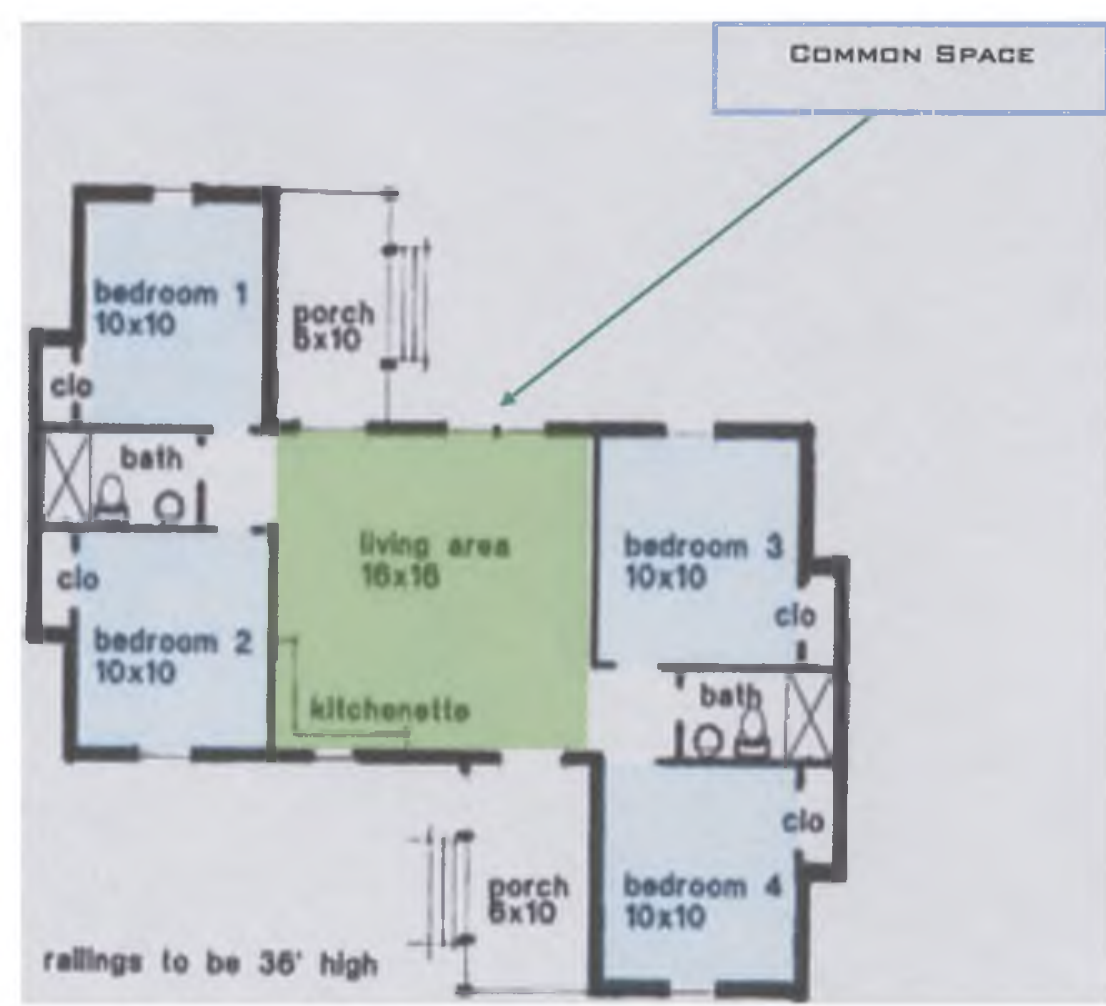

FIGURE

26

agape shelter, New facilities flodr plan of TYPICAL COTTAGES

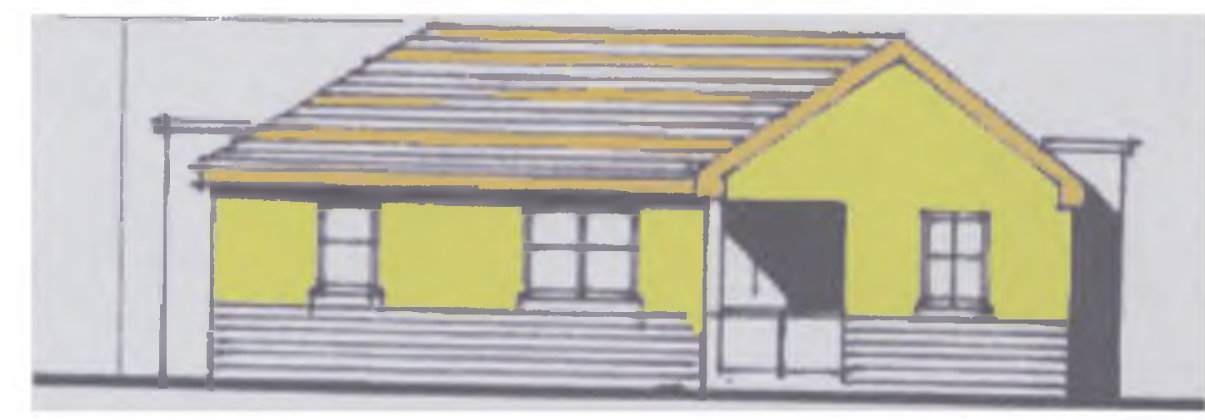

FIGURE

27

Agape Shelter, New facilities Elevation of Typical CatTAGES 


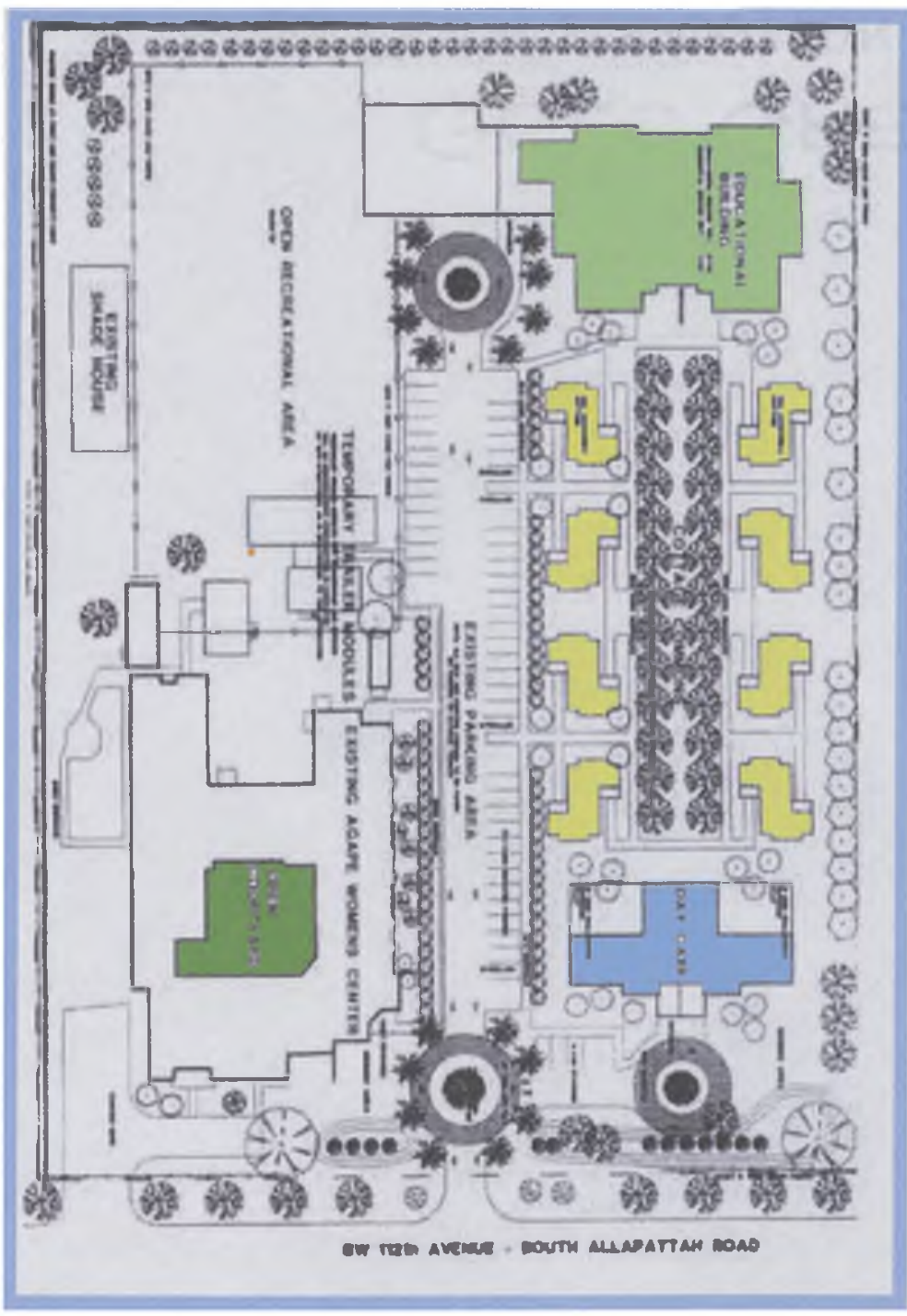

FIGURE

2 a Agape shelter, New facilities, site plan
B. CASE STUDY $B$.

YMCA WOMEN SHELTER, CINCINNATI, DHIO

THE yMCA BATTERED WIMEN'S SHELTER IN CINCINNATI IS QNE OF tHE LATEST DESIGNS IN WLMEN'S SHELTERS IN THE U.S. IT WAS DESIGNED GY KZF AREHITECTS IN 1999 FOR THE YMCA ENTITY DEDICATED TO AIDING WOMEN IN DISTRESS.

THE 11 , VERY COMFORTABLE AND FLEXIGLE WAY, IN THIS MONOLITHIC BUILDING, THE COMMON AREAS ARE LOCATED IN THE GROUND FLOOR IN FAIRLY OPEN SPACES SHARED BY THE RESIDENTS (SEE FIGURE 2B). THE KITCHEN, LIVING ROOM, AND THE DINING ROOMS ARE LOCATED IN THE FIRST FLOQR, WHICH GIVES IT A HOME-LIKE FEELING. BEFORE DESIGNING THE BUILDING, KZF INTERVIEWED CHILDREN FROM DTHER SHELTERS. THEY FOUND THAT CHILDREN DESCRIBED SPECIFIC AND DIFFERENT STRESSFUL SITUATIONG that conveyed the difficulties of not having a permanent hame. The STRESSFul EXPERIENCES DESCRIBED INCLUDED MOVING FREQUENTLY, LEAVING

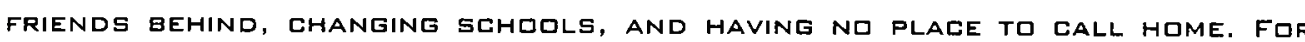
THEM, LIVING IN TRANSITIONAL HQUSING GROUGHT A REPRIEVE.

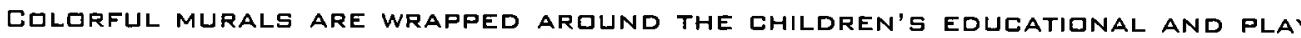
AREAS. THEY GREATE A FUN AND happy ATMOSPHERE FOR THE CHILDREN. THE design clearly demonstrates the prigrity placed an the ghildren (see FIGURE 3D). AS DISCUSSED PREVIOUSLY, PRESERVING CHILDHODD IN SHELTERS IS DNE OF THE CRUCIAL VARIABLES IN SHELTER DESIGN.

IN THIS STUDY CASE THE CONCEPT OF ASYLUM DESIGN INCLUDED ACCOMMODATING mULtiple families and cReating spaces that could feel Like home. ON THE 

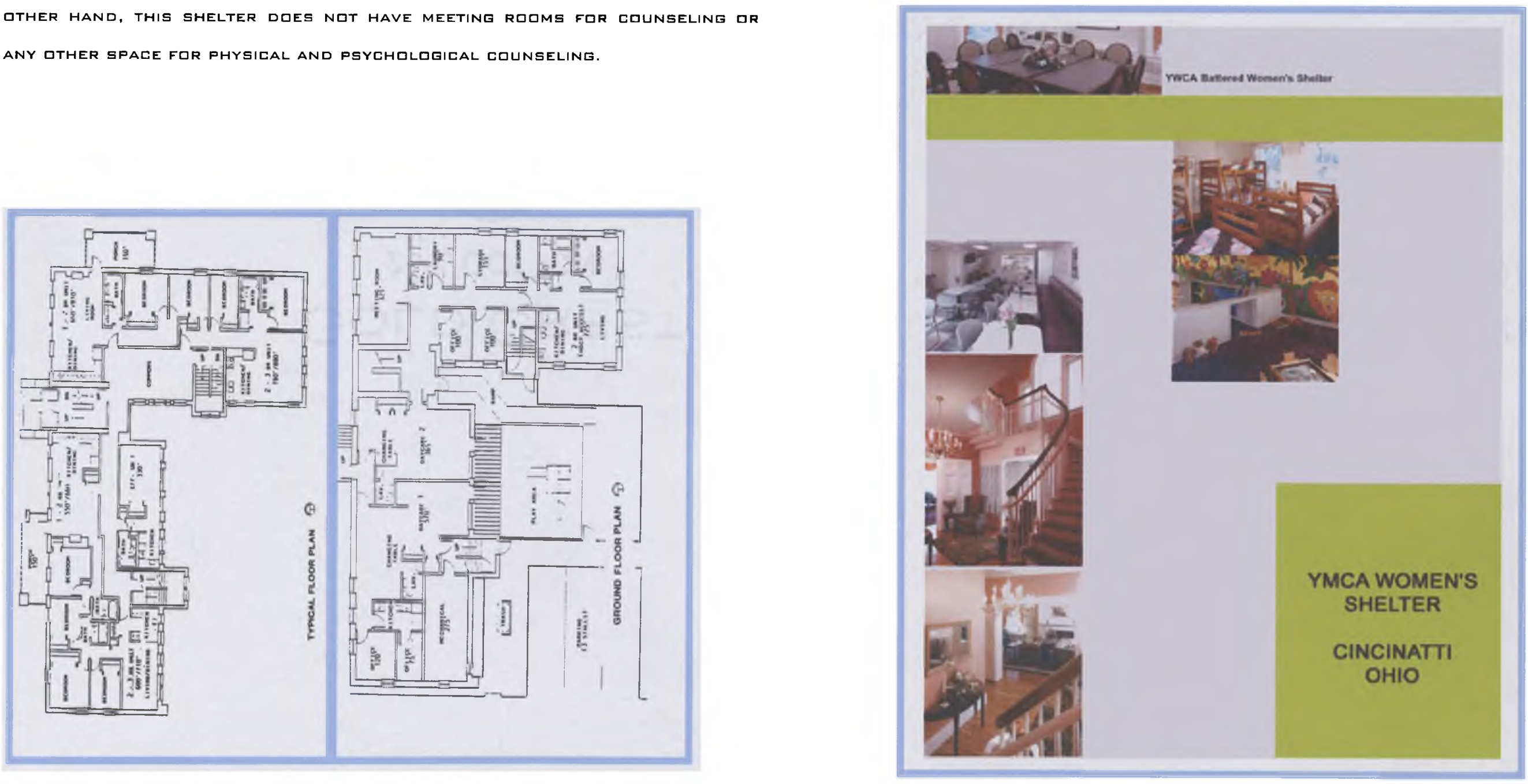

\begin{tabular}{|c|l|}
\hline Figure & \\
\hline 29 & YMCA WIMEN'S SHELTER FLOUR PLANS \\
\hline
\end{tabular}

\begin{tabular}{|c|c|}
\hline FIEURE & \\
\hline 3 Y & \\
\hline
\end{tabular}




\section{c. CASE STUDY C.}

CARPENTER SHELTER, ALEXANDRIA, VIRGINIA

ALEXandRIA's study case was selected for the purpose gf studying the ENVIRONMENTAL FACTORS IN SHELTER LIVING. THE ENVIRONMENT IN WHICH A PERSON DPERATES has A STRONG INFLUENCE IN THAT PERSON'S WELL-GEING AND geHAVIOR, AND THE REALITY OF THE PERSON'S ENVIRONMENT IS HOW THE PERSON PERCEIVES IT (RIGERs, STONE AND CHURCH 1966).

THIS CASE STUDY SERVES AS THE MOST DRASTIC GASIS DF COMPARISON IN DIRECT CONTRAST WITH THE PRIPISAL IN THIS THESIS. CARPENTER SHELTER IN VIRGINIA IS A WAREHLUSE that WAS CINVERTED INTO A WOMEN'S SHELTER IN 1997. THIS CAsE STUDY MADE VERY CLEAR THE IMPORTANCE OF HAVING A STRATEGICALLY DESIGNED PROGRAM FOR THIS THESIS PROJECT. THE LACK OF SAFETY, FLEXIGILITY, AND

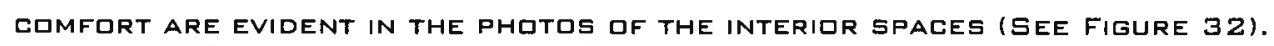
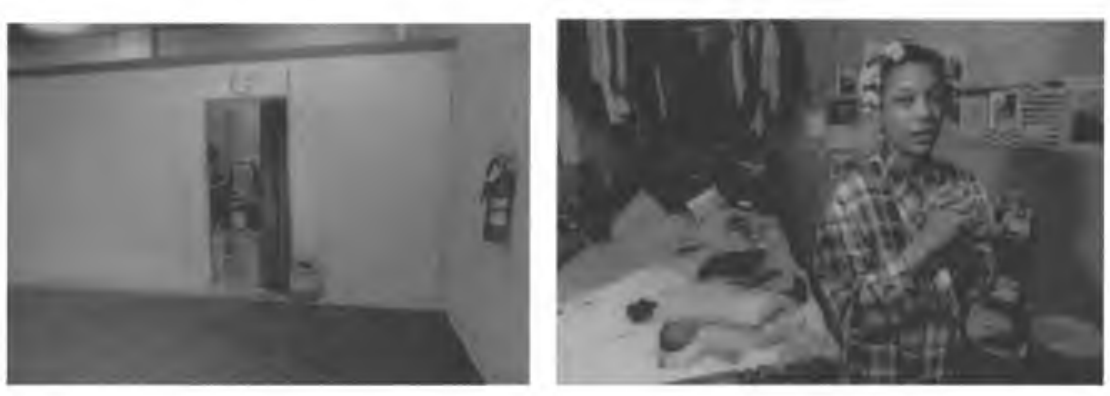

\begin{tabular}{|c|c|}
\hline Figure & \\
\hline 31 & CHILDREN IN ALEXANDRIA SHELTER \\
\hline 32 & WIMAN IN HER ROIM \\
\hline
\end{tabular}

"WOMEN AND CHILDREN GOING THROUGH THE PHASE OF MOVING FROM A HIME ENVIRONMENT TO A SHELTER NEED THE QPPQRTUNITY TO REST, TO ASSESS THEIR SITUATIONS, AND TD DEVELOP A PSYCHOLGGICAL AND PHYSIOLGGICAL SENSE IF SAFETY. DNCE WOMEN FEEL THEY AND THEIR CHILDREN ARE SAFE, THEY OVERCOME THE PSYCHOLOGICAL EFFECTS OF BATTERING" (SHOSTACK 2001 ).

the NeEds identified in the abqve qudte are not met in the carpenter WOMEN'S SHELTER. A THIN FABRIC CURTAIN DIVIDES THE CUBICLE ENTRANCE DOTRS.

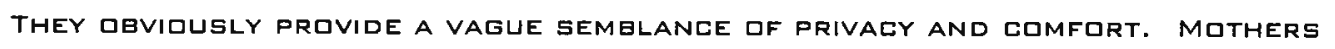
AND CHILDREN SHARE THE SAME BED AND UNITS WITH MORE THAN ONE ROOM HAVE TO SHARE BATHROOMS. THESE LIVING GONDITIONS ARE NOT THE MOST APPROPRIATE Far FOSTERING SELF-esteEM ar SELF-RELIANCE. CARPENTER SHELTER DIES Nat OFFER SUPPORT SERVICES SUCH AS PSYCHOLOGISTS DR PRIVATE HEALTH CARE. IT ONLY SERVES AS A PLACE THAT HELPS KEEP WIMEN AND CHILDREN FROM GECOMING HOMELESS.

CARPENTER SHELTER DIES NOT PROVIDE SUFFICIENT SERVICES QR PRIVACY FOR WOMEN WITH CHILDREN (SEE FIGURE 34). THE LACK DF FOOD PREPARATION AREAS

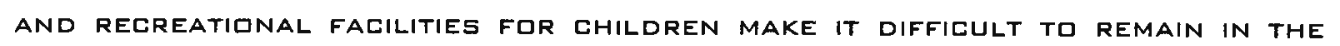
shelter far mare than a few WeEks. Figure 33 provides a descriptive VISUALIZATION OF A CHILD'S DREADFUL LIVING CONDITIONS. 

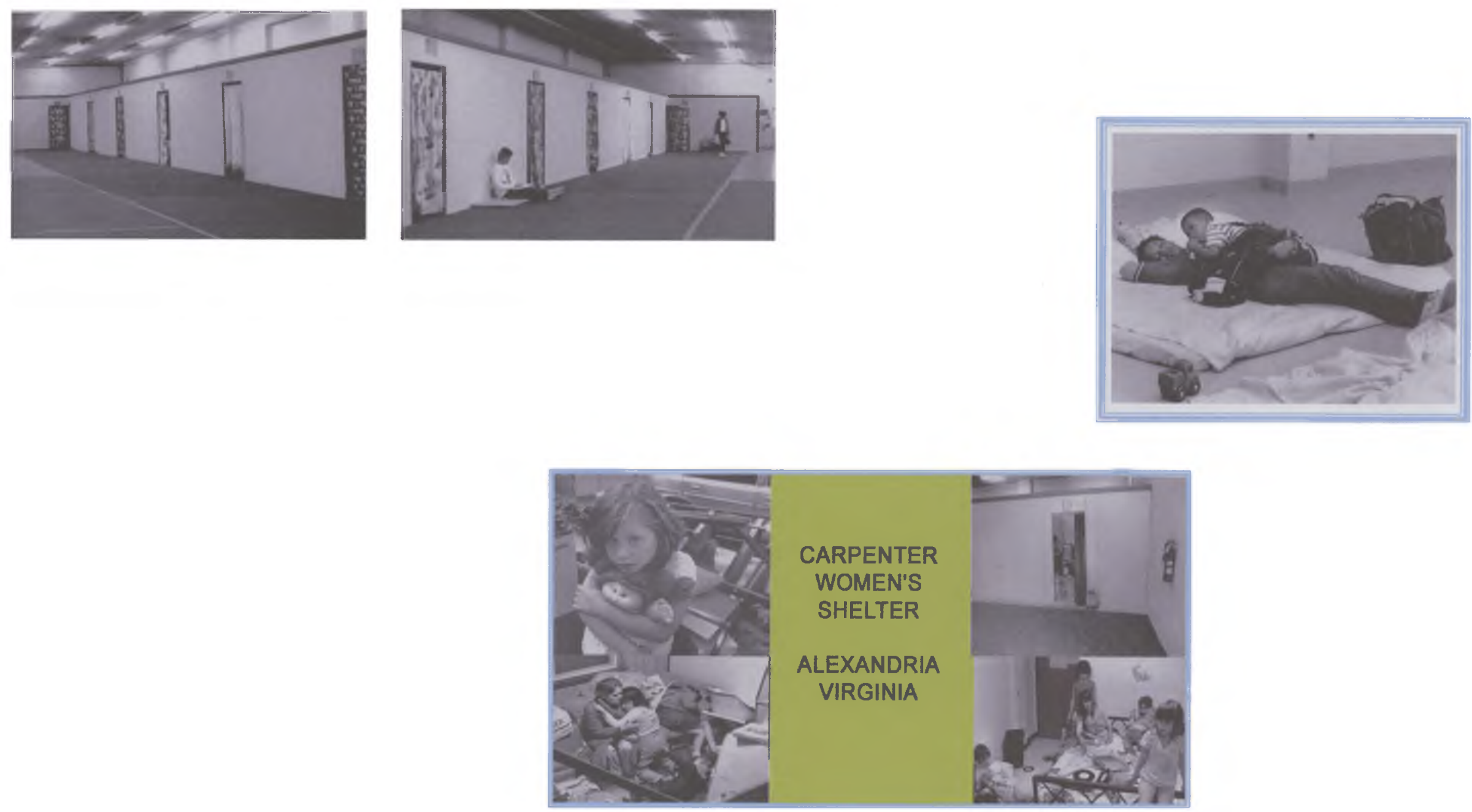


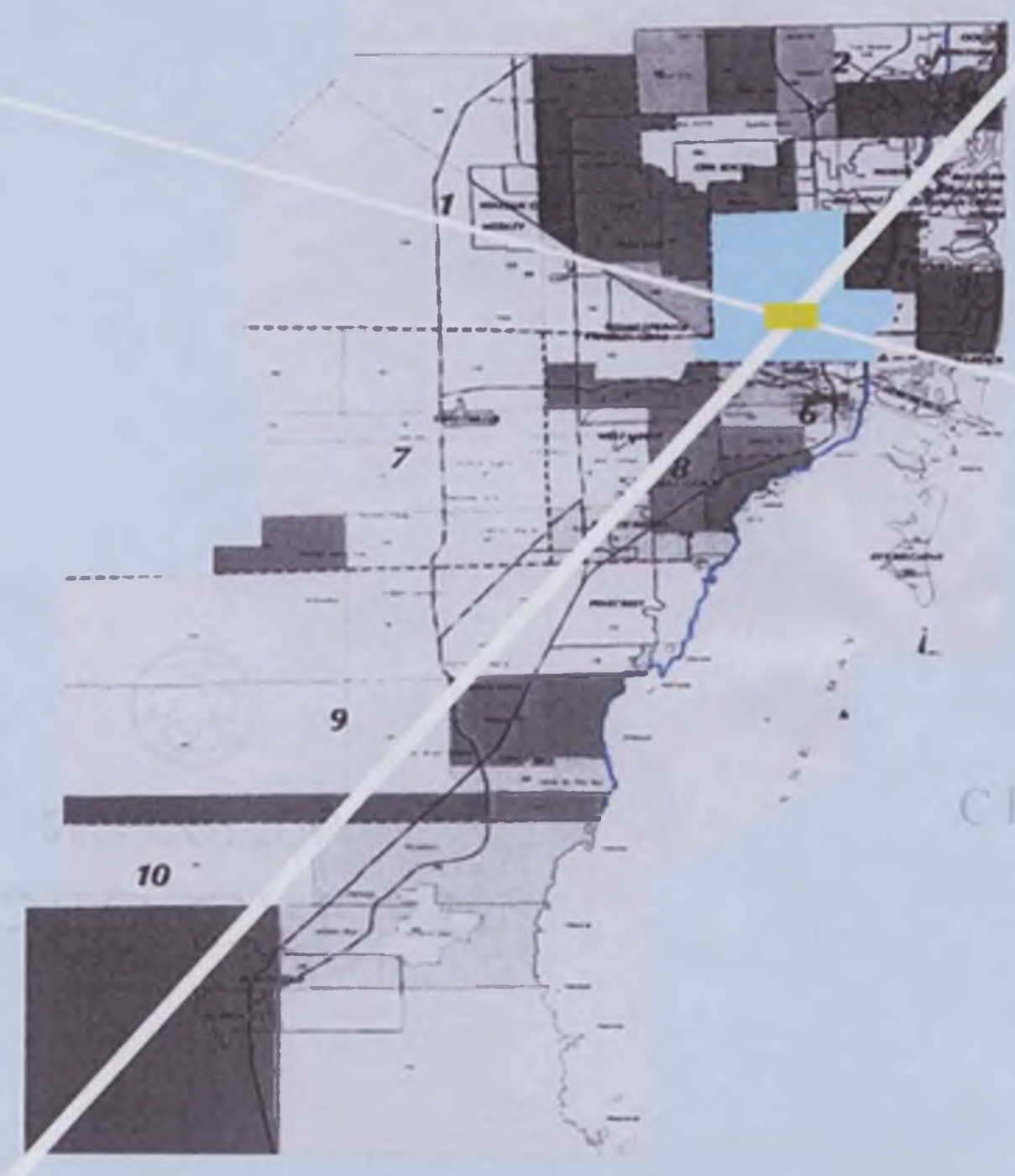


CHAPTER $V$

STATISTICAL DATA

\section{a. national and state statistics}

THE STATISTICAL DATA FOR DOMESTIC VIGLENCE IN FLORIDA ARE INE OF THE HIGHEST in the United States. In Miami hardly a day goes by without the news REPORTING DIMESTIC VILLENGE CASES. IN THIS COUNTRY, A WOMAN IS GEATEN EVERY NINE SECONDS, AND ONE IS MURDERED BY HER HUSBAND OR BOYFRIEND EVERY SIX hours (U.5. Dept. of Justice bureau dF JUstice Statistics 2001). Damestic

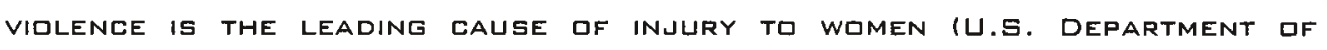
JUStice). NONETHELESs, CHILdREN ARE PRESENT DURING BD\% of the tIME DURING THE ACT OF VIGLENCE. IN ADDITION, OF THE CHILDREN WHO LIVE IN THIS TYPE DF ENVIRINMENT, 50\% EVENTUALLY BECOME GATTERERS OF WOMEN THEMSELVES. IN THE U.S. AN Estimated 1,500 WOMEN ARE MURDERED EACH YEAR GY THEIR HUSBANDS, BUT MURDERS REPRESENT ONLY A TINY FRACTION OF DOMESTIC VIOLENCE (U.S. DEPARTMENT DF JUSTICE zQDZ).

IDENTIFYING THE COMMUNITY WITH MOST REPORTED EASES IN MIAMI WAS THEREFORE A

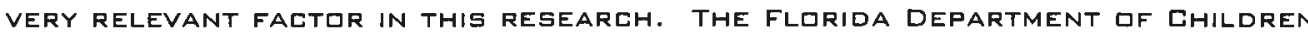
and families reptrted the fqLlowing cammunities in NORTHEAst Miami as the most affected gy domestic Viglence: Miami Shores, North Miami, biscayne gardens, AND LitTle River (SEe figure 34 ).

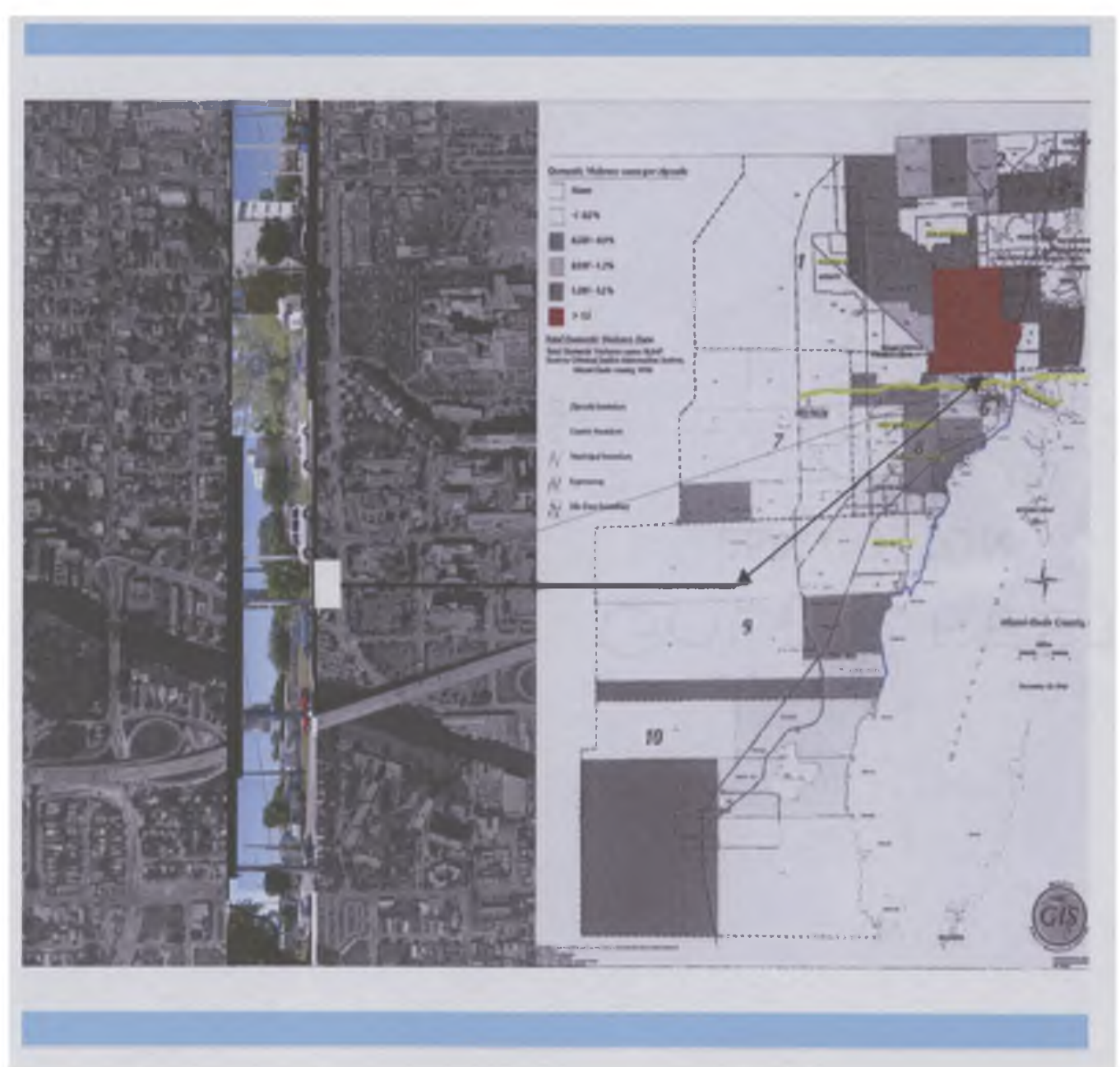

FIGURE

34 Statistical Data indicator Map fur Miami, florida 


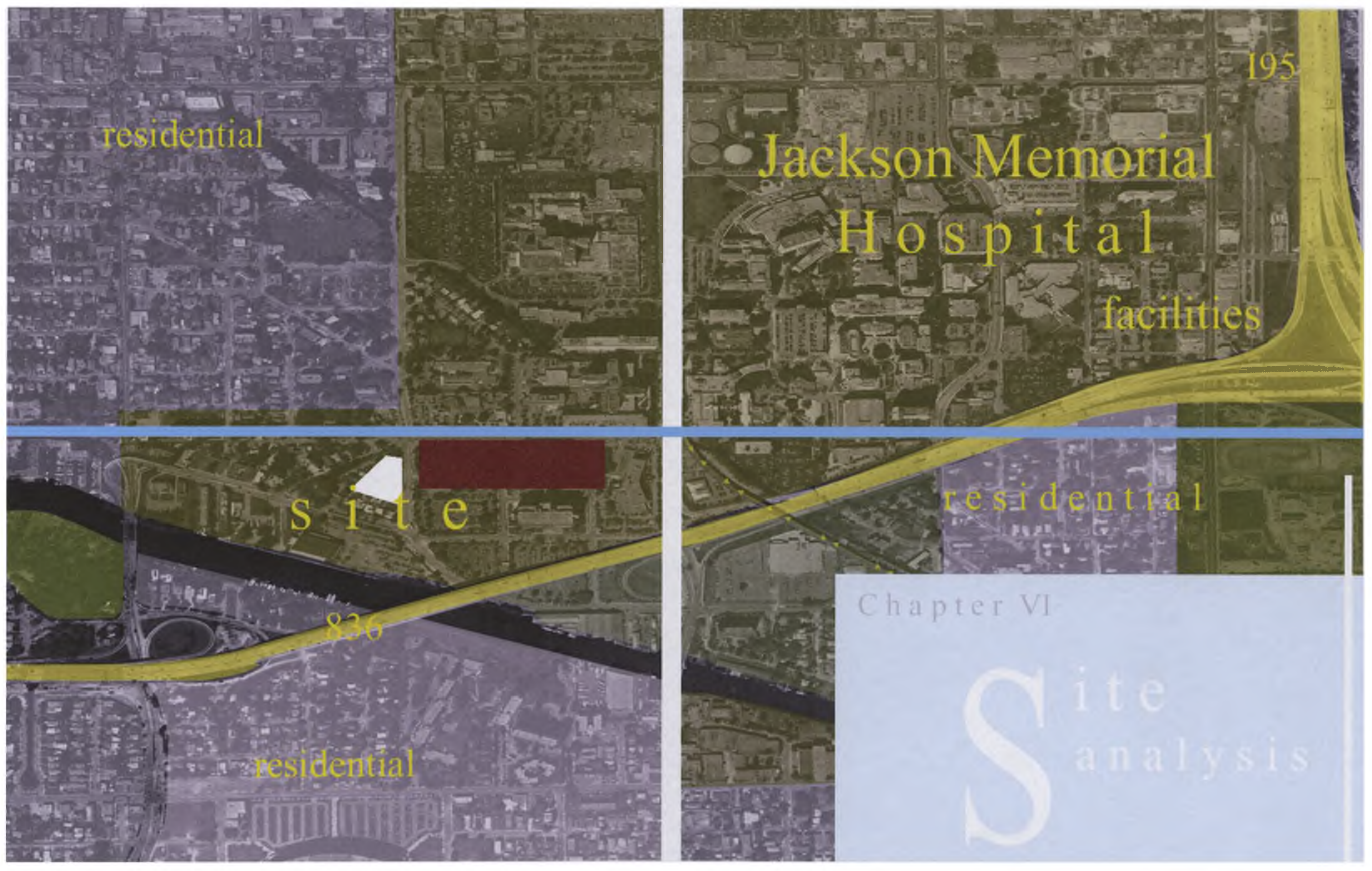


CHAPTER VI

SITE ANALYSIS

\section{A. URBAN ANALYSIS}

WHERE TO LICATE AN ASYLUM FOR WOMEN WITH CHILDREN WAS A POINT GF contentign getween thase Wha gelieve that WOMEN SHOULd ge campletely SECLUDED AND ISOLATED FROM THE GITY, AND THOSE WHO BELIEVE THAT WIMEN NEED TO HAVE ACCESS TO THE BENEFITS GF INTERACTION WITH THE WURLD AT LARGE. THIS THESIS MAKES THE GASE THAT THE SHELTER SHOULD IN NO WAY gE ISOLATED. Statistics tell that the gatterers are more likely to attempt to find the WOMEN IF they ARE midDEN than IF they kNOW WHERE they are located (ShIstack 2001). Therefare, Wamen gaing through SUCH Difficult SITUATIONS NEED SHELTER IN A PQSiTIVE ENVIRONMENT THAT ENCQURAGES THEM TO

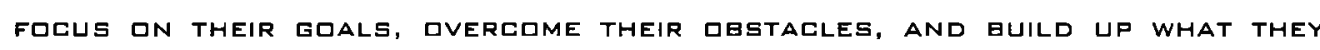
HAVE LOST.

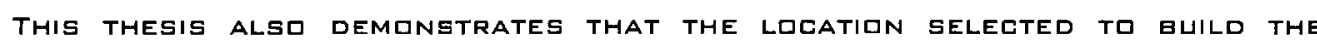

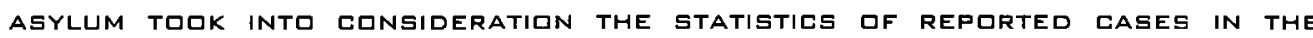
adjacent areas. this means that the women will have the gpportunity to

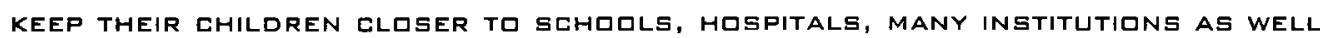
as public transportation. furthermore, because the site is close to BUSINESS AREAS, IT WILL WIDEN THE FIELD GF JOB OPPORTUNITIES. IN ADDITION, THE ASYLUM WQULd HAVE THE ADDED EENEFIT GF HAVING GOMMUNITY SUPPGRT IN THE FQRM OF MURE VILUNTEERS AND COMMUNITY INVGLVEMENT IN FUNDRAISING activities. To top it aff, the area is fairly secure since the police

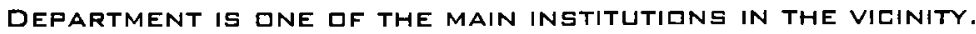

UNDLUGTEdLY, SHELTERs SET UP IN CONVERTED PRIVATE hIMES IN RESIDENTIAL AREAS MAY ENCOUNTER GPPISITION FROM NEIGHEGRS WHO GLAIM THAT THE FACILITY Will attraet dangerqus gr strange pegple, create parking proglems, and REDUCE PRIPERTY VALUES. CERTAINLy, THE URGAN SETTING SELECTED IS A NONresidential, NON-commercial area where the institutianal facilities

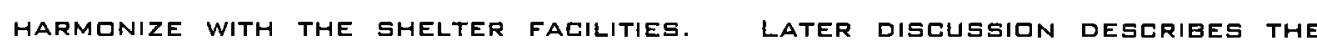
SPECIFIC PRIJECT SITE AND ITS SURROUNDINGS.

the miami-dade Building and Zuning Department codified that shelter FACILITIES ARE NUT CLASSIFIED AS RESIDENTIAL QR COMMERCIAL STRUCTURES (MIAMIDade county commission far Wamen 2003). THE Zaning Department

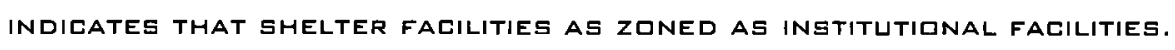

The urgan diagrams show the gurRqunding areas of the chISEN Site. It is SHIWING TRANSPIRTATION ROUTES, GUS STATIONS, SITE RELATIONSHIPS WITHIN THE

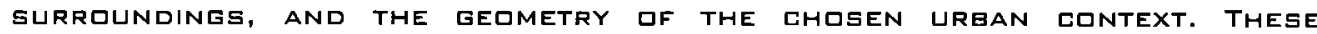
diagrams (see Page 37 ) indicate same Variables that were taken iN CONGIDERATION TO COME UP WITH THE DESIGN STRATEgIEs. 


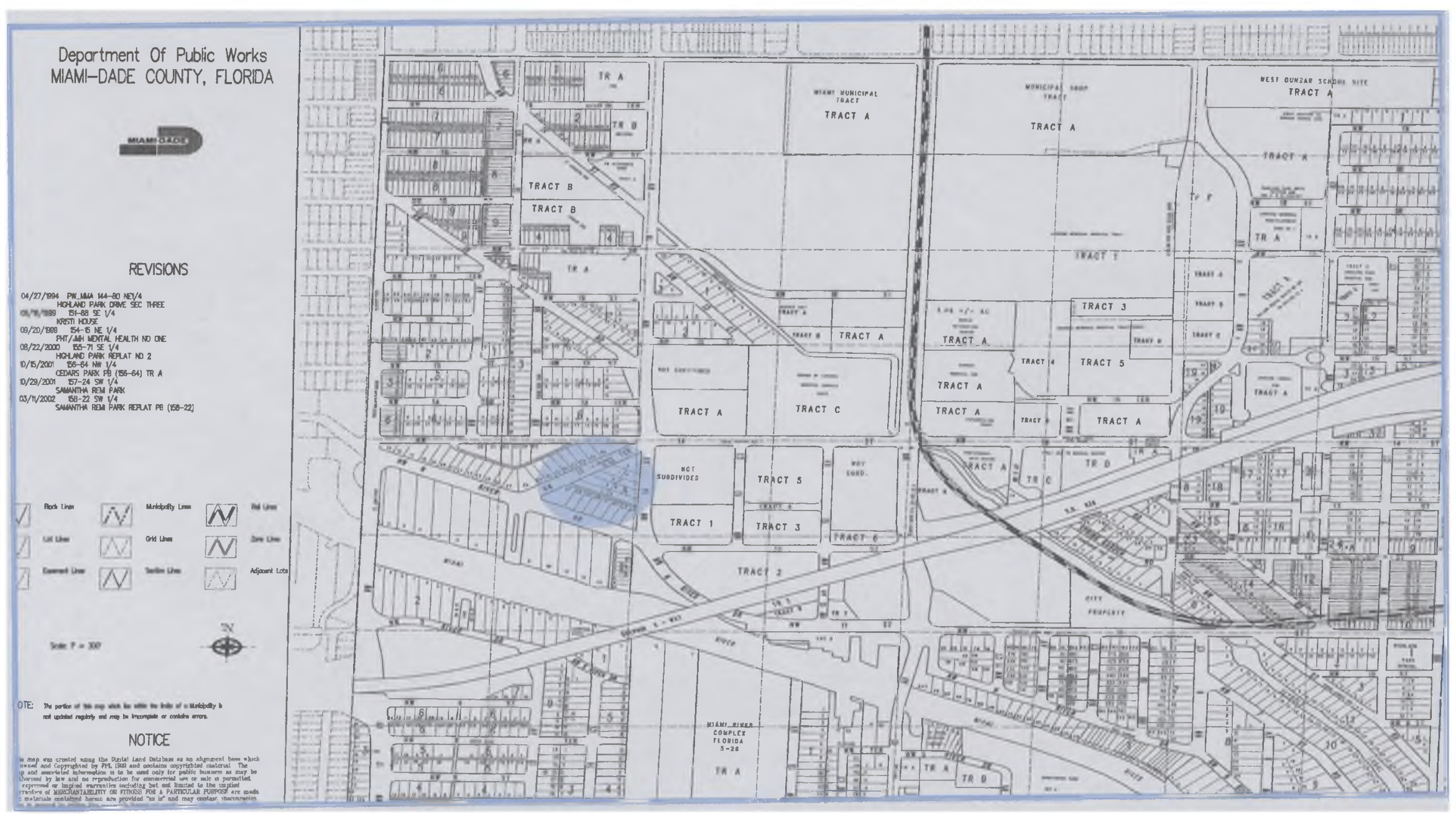



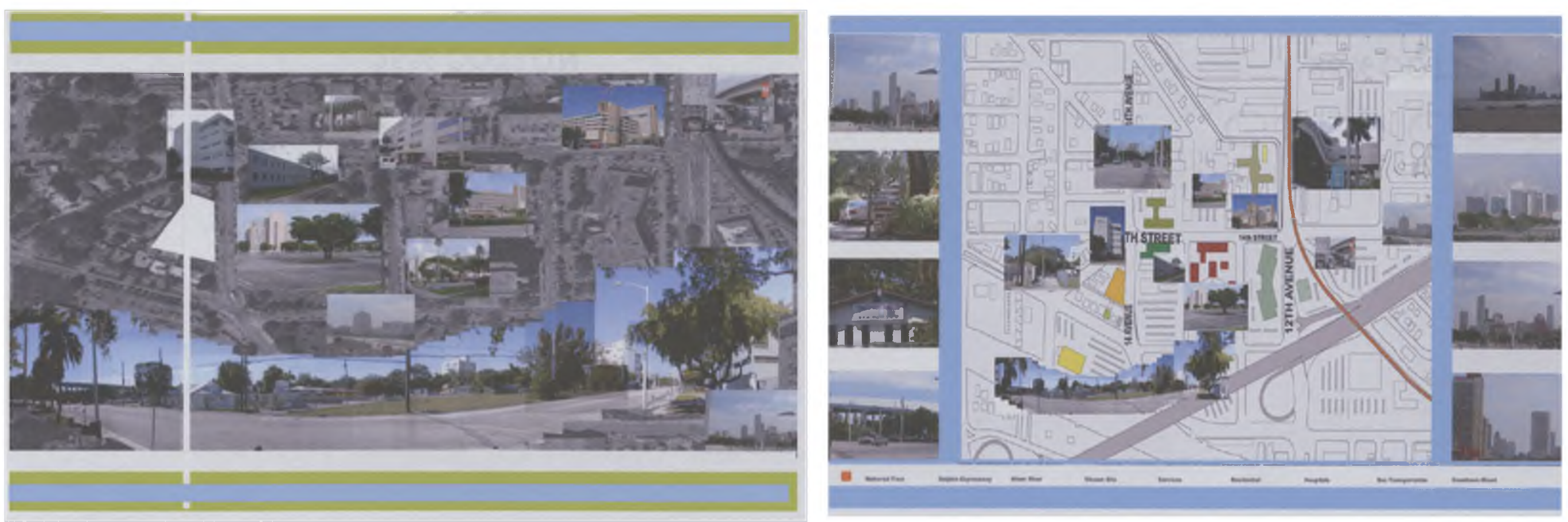

FIGURE

36 PHOTOMONTAGE of AERIAL VIEW OF

SELECTED SITE

\begin{tabular}{|c|l|}
\hline FIGURE & \\
\hline 37 & $\begin{array}{l}\text { PHOTOMONTAGE OF SURRQUNDING OF } \\
\text { SELECTED SITE }\end{array}$ \\
\hline
\end{tabular}



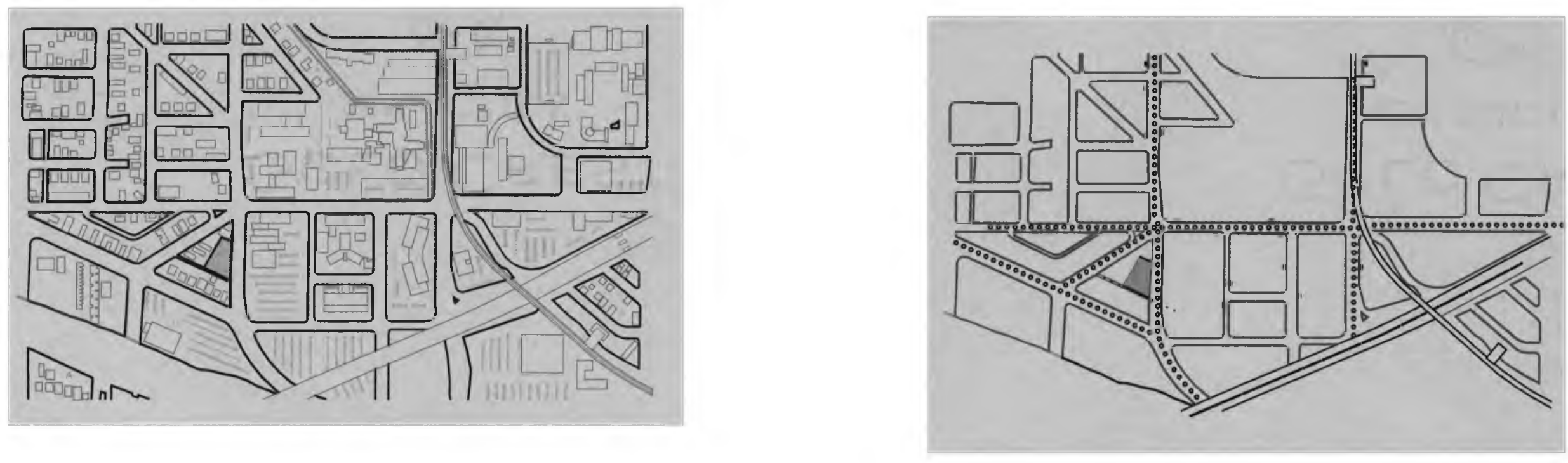

CONTEXT

TRANSPORTATION
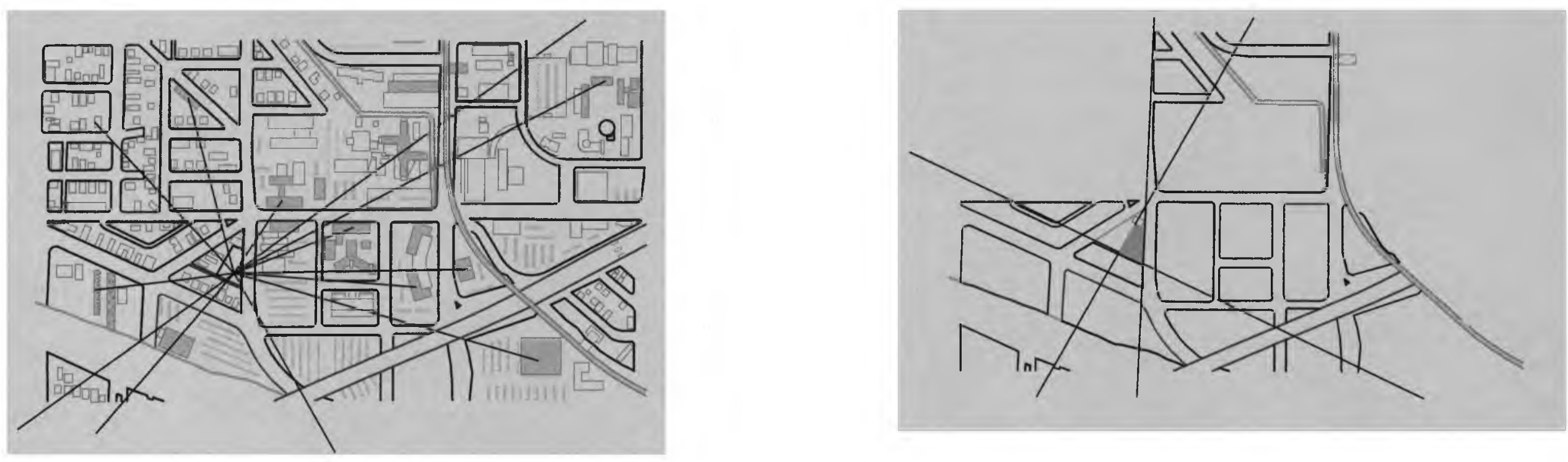


\section{B. Project SITE}

"BQ\% वF WOMEN PREFER TD BE IN A PLACE WHICH CAN FACILITATE THEIR DAILY LIFE IN TERMS OF TRANSPRRTATION, MARKETS, SCHOOLS, AND HOSPITALS FOR THE BENEFIT OF THEIR IWN CHILDREN" (LOSEKE 2 DI1).

“TLDAY MURE WOMEN'S SHELTERs ARE DISCLLSING THEIR LOCATIONS, RATHER THAT KEEPING THEIR LOCATION SECRET. IN GENERAL, SHELTER DIRECTORS IN OPEN FACILITIES BELIEVE THAT DISCLISING THEIR LOCATION HELPS MAKE COMMUNITIES MORE AWARE OF DOMESTIC VIOLENCE, MAKES IT EASIER FUR ABUSED WOMEN COME TD FIND THE SHELTER AND ALSO HELPS TO KEEP THE VOLUNTEERS, STAFF, RAISE FUNDS AND DINATIONS" (LOSEKE 2001).

THE CHOSEN SITE FOR THE THESIS PROJECT IS AN EMPTY LOT BELONGING TO THE CITY of Miami. the site is located at Nurthwest 14 Street and 14 avenue, miami. THIS SITE RETAINS TREMENDQUS ADVANTAGES FROM ITS SUPPORTIVE ENVIRONMENT.

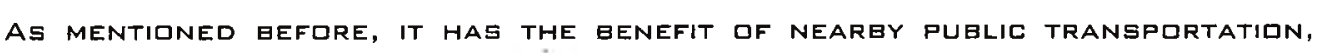
hISPITALS, SCHQILS, THE PQLICE DEPARTMENT, AND MANY OTHER SUPPORTING FACILITIES WITHIN WALKING DISTANEE. IT IS IMPGRTANT TO MENTION THAT THE PGLICE

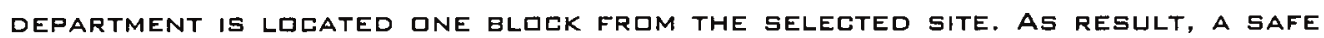

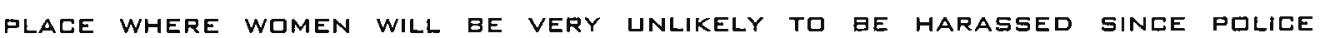
PATRILS ARE IN LONTINULUS TRANSIT AROUND THE AREA.

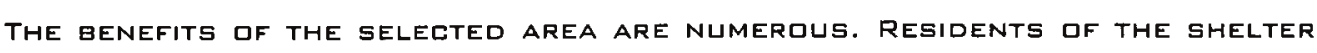
ARE WALKING DISTANCE FROM THEIR MEDICAL APPOINTMENTS, CAN EASILY VISIT THE

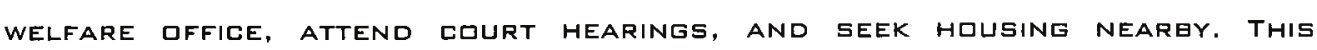

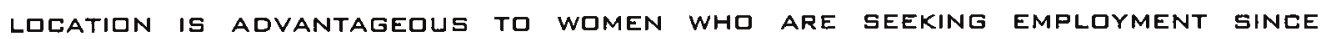
DOWNTOWN MIAMI IS LESS THAN TEN MILEs aWAY FROM THE SITE AND tHE INDUSTRIAL areas are ten to fifteen miles away. in addition, a pleasant, safe NEIGHBgrhogd, AND community aCCEPtance of the shelter are positive ASPECTS DF ITS SLPPIRTIVE ENVIRONMENT.

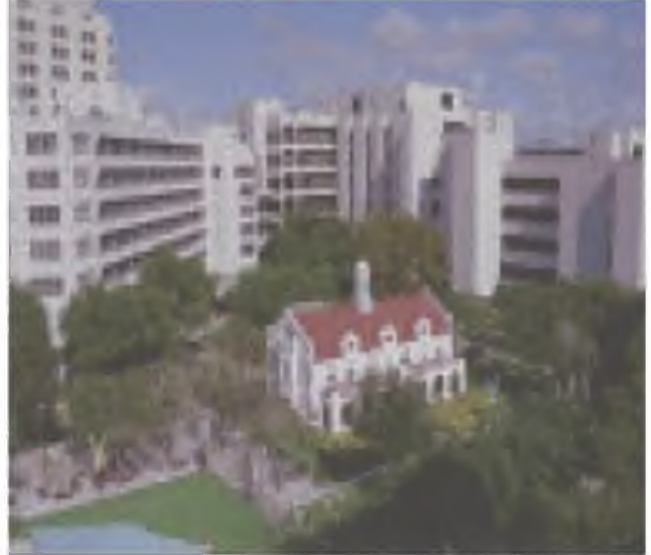

\begin{tabular}{|c|c|}
\hline Figure & \\
\hline 39 & JAEKSON MEMORIAL HOSPITAL, 1916 BUILDING \\
\hline
\end{tabular}

A BRIEF HISTORICAL SNAPSHOT OF THE SITE SURRQUNDINGS IS RELEVANT TO THIS

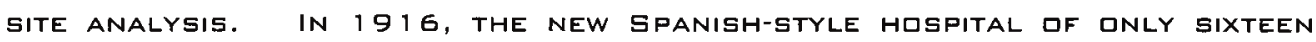
ROGMS WAS FIUNDED AND LOCATED TWENTY BLOCKS FROM THE DOWNTOWN AREA. AT

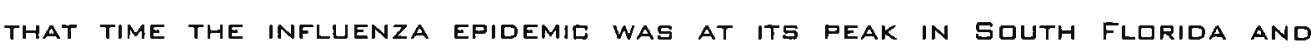
HUNDREDS OF PATIENTS WERE WAITING for rogMs. LATER, IN THE 1920 S THE hISPITAL GREW to 250 patient ROIMS, always kEeping the spanish arghitectural style (see figure 42). Then in the 1950 s came the CONSTRUCTION BOIM THAT RESULTED IN THE LARGE BUILDINGS IN THE SURROUNDING AREAs, WHIEH EMPLaYed internatianal style architecture rather than the Well-kngwn art dego, implemented in Miami Beach (Public health trust, JACKSIN HEALTH SYSTEM). STILL, TODAY THE AREA RETAINS ITS INTERNATIONAL STYLE RATHER THAN THE MURE MODERN ARCHITECTURE THAT WAS BORN IN ADJACENT AREAS LIKE DIWNTOWN MiAMI. 


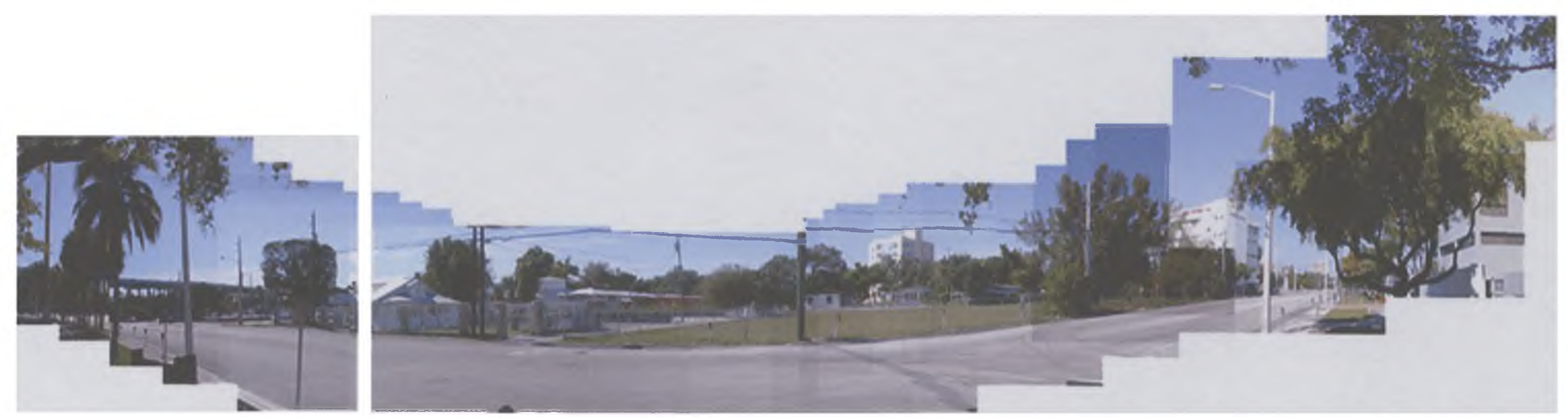

FIGURE

4 P Photamantate df Selected Site 


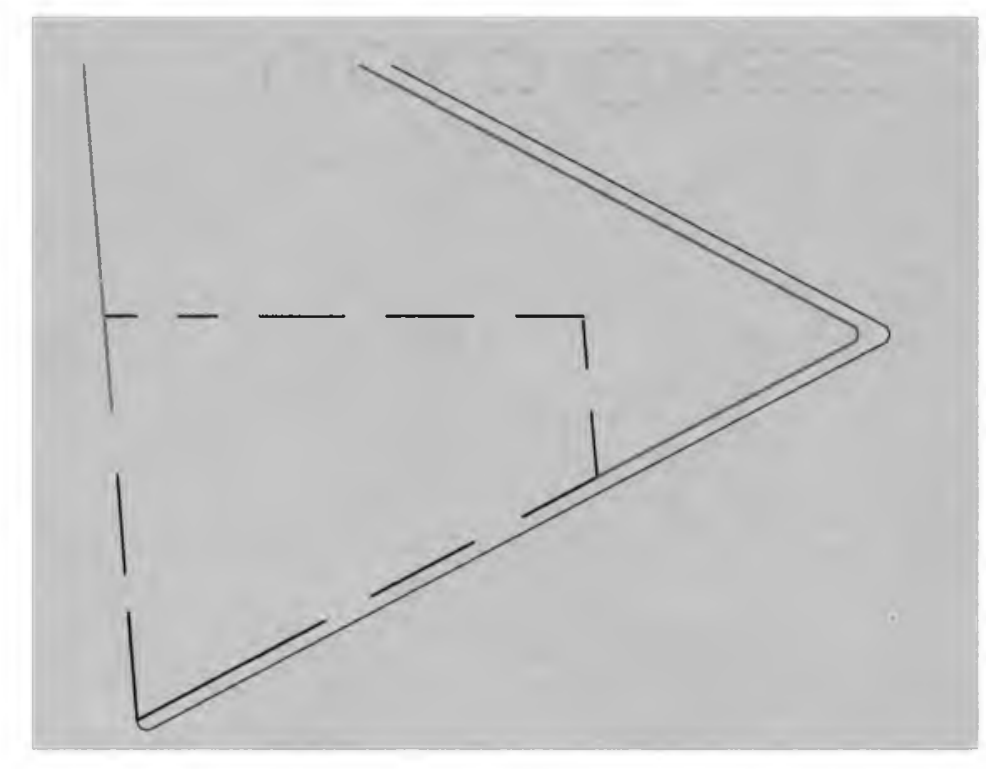

SITE GEOMETRY

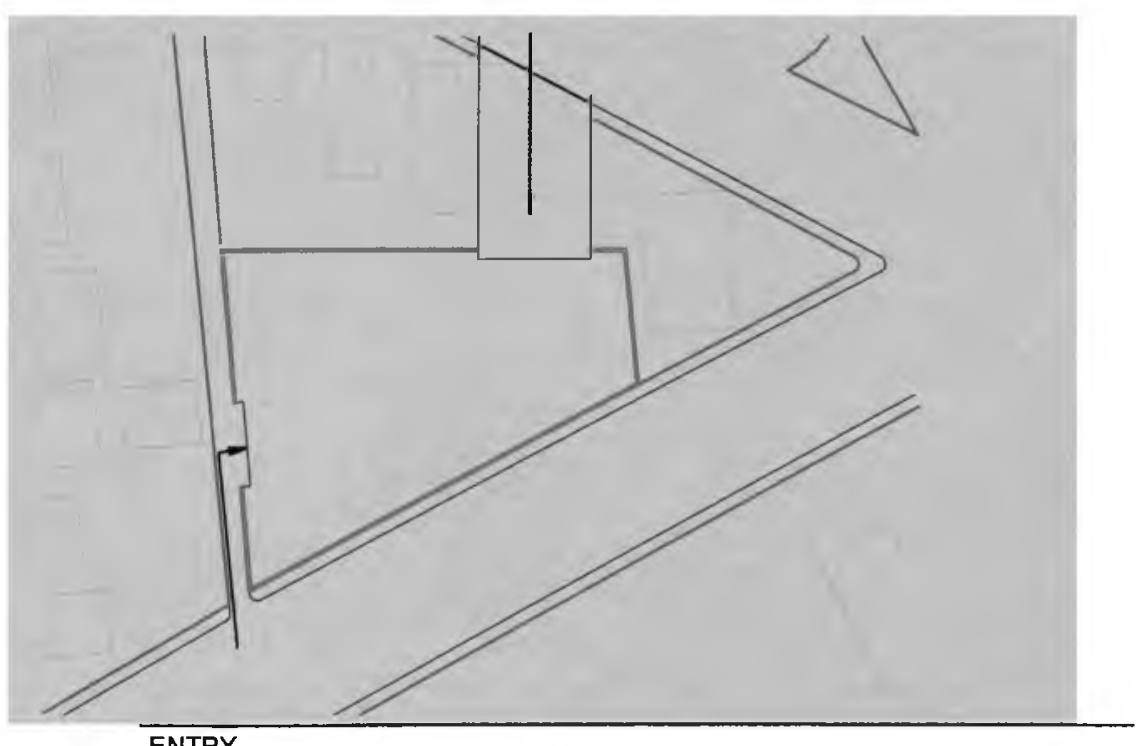

ENTRY
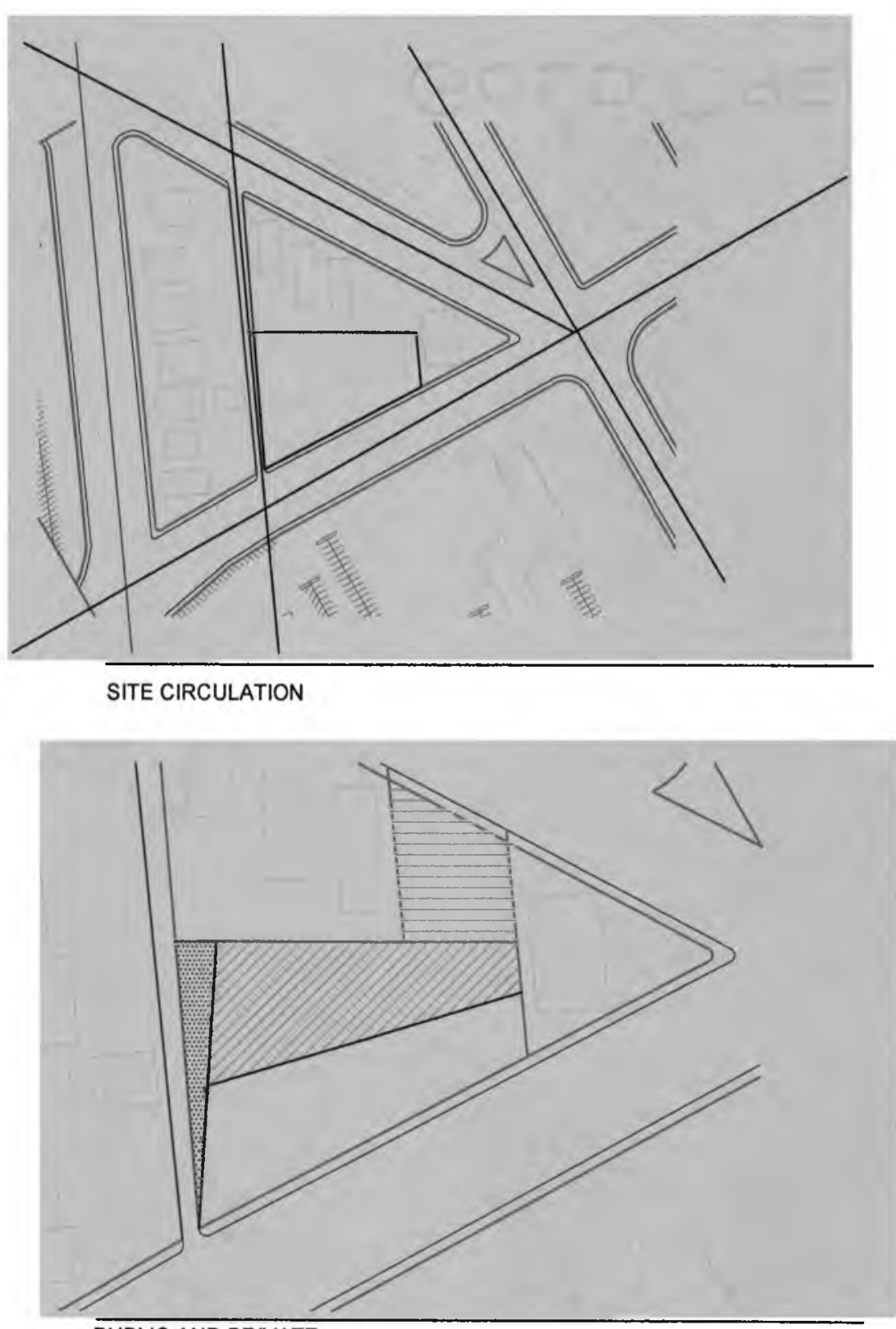

PUBLIC AND PRIVATE

\section{FIGURE}

41

PRDJECT SITE DIAGRAMS 


\section{ATTACHMENT}

\section{BOUNDARIES}

\section{I G H T I N G}

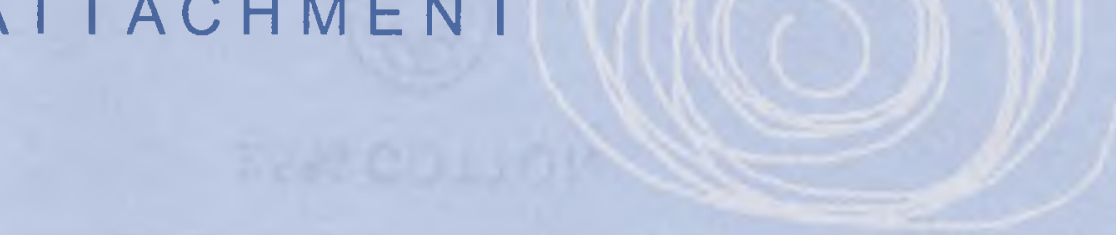

Chapter VII 
lighting

a t t a chment

boundaries

Chapter. VII 
CHAPTER VII

DESIGN STRATEGIES

\section{A. Degign Strategy I: Bqundaries}

BQUNDARY: A LINE THAT MARKS A LIMIT, A DIVIDING LINE (OXFORD, 1986). FROM THE CONCEPT OF PROTECTION FOLLOWS NATURALLY THE GONCEPT OF BQUNDARY AND LIMITS. BIUNDARIES CAN GE EITHER SEEN IR UNSEEN. IN AN ABUSED WOMEN'S shelter, the first idea that came to mind was the walls that separate the UNSAFE AND SAFE ENVIRONMENTS. THE WALLS OF A SHELTER GENERATE A SENSE of safety AND control. THEy MUST be clear physical goundaries. HOWEVEr, to THE WOMAN THAT LIVEs BEHIND THOSE WALLS, THEY ARE MENTAL BARRIERs AS WELL. THEY REPRESENT A SEPARATION FROM HARDSHIP AND DANGER, A SEPARATION OF THE QUTER AND INNER WORLDS.

THE PRIMARY INTEREST OF THIS THESIS, HOWEVER, DOES NOT LIE IN EMPHASIZING THE LIMITS OF THE WOMEN'S SPACES, BUT RATHER IN THE APPARENT DISSOLUTION DF THOSE gLUNDARIES IN A MANNER THAT ENGENDERS A FEELING OF LIBERTY FROM THE ABUSE. IN PARTICULAR, IT IS THIS LATTER IDEA THAT EMBODIES THE DICHOTOMY BETWEEN CONFINEMENT AND FREEDOM, HELPLESSNESS AND POWER.

FIR THE PURPQSES OF THIS DESIGN THE BQUNDARY EXPRESSION WORKS ALSI AS A MATTER of FUNCTION. THE OUTER WALls articulate the functions of SECURITY AND SAfETy (SEe figure 43). THEy surRound the spaces WHere liberating, self-enhancing and healthy mental processes can take place. They then BECOME DUAL-FUNGTION-BOTH A MEANS of SAFETY, AND EMPOWERMENT.
THE gQUNDARY DESIGN STRATEgY WAS GUIDED BY LOSEKE'S STATEMENT. IN HIS gotk, the sodial ganstrlation of Wife Ablse, loseke states that the nation IF POWER ARISES FROM THE RELATIONSHIP AMONG RELATIVES (LOSEKE 2LO1). HIS

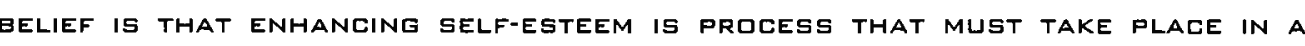
PROTECTED SPACE, WHERE WOMEN CAN EXPERIENCE A SENSE OF SECURITY AS WELL as cantrol, in this case amang non-relatives. Therefare, the nation of RECLAIMING CONTROL IS A SLOW PROCESS IN THE EVERYdAY LIFE OF WOMEN.

THIS THESIS ARGLES THAT REHAGILITATION IN SHELTERS FOR GATTERED WOMAN CAN

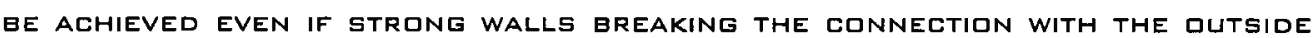
WIRLD MARK A PHYSICAL BLUNDARY BETWEEN THE WOMEN AND SOCIETY. THAT

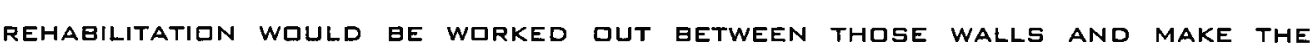
WOMEN BE ON CONTRIL IF THEIR FUTURE. AS LOSEKE STATES, THE FATHER'S RILE IN A FAMILY IS TO PROVIDE PROTECTION FOR THE MOTHER AND CHILDREN, BUT IF THE

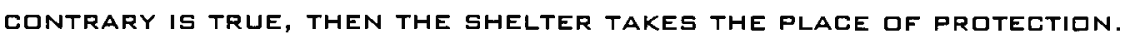

THE DESIGN BQUNDARY STRATEGY WAS USED TO ENSURE SECURITY AND WELL-GEING. the closed enVelope character of the building reVeals this design PRINCIPLE. Whereas We appreciate in the architectural dRaWings, site PERIMETER “LIMITS” WERE TAKEN IN CONSIDERATION AS THE gQUNDARIES PRINGIPLES. THE eXterior WALls of THE shelter delineate the LIMITS OF THE SITE ITSELF. the external expressians af this minimalist design also reveal the SEPARATION af THE INTERIOR AND EXTERIOR WORLD. THOSE WERE CARRIED Gy THE EXTERILR FAEADE. 
SCHEMATICS WERE PREPARED FIR THE gQUNDARY STUDY. THESE SKETCHES SHOW THE SEGMENTS AS THE PORTRAYAL OF LIMITS. THESE SEgMENTS WERE CONVERTED AS STRONG BEAMS AS THE FIRST STATEMENT OF THE DESIGN.

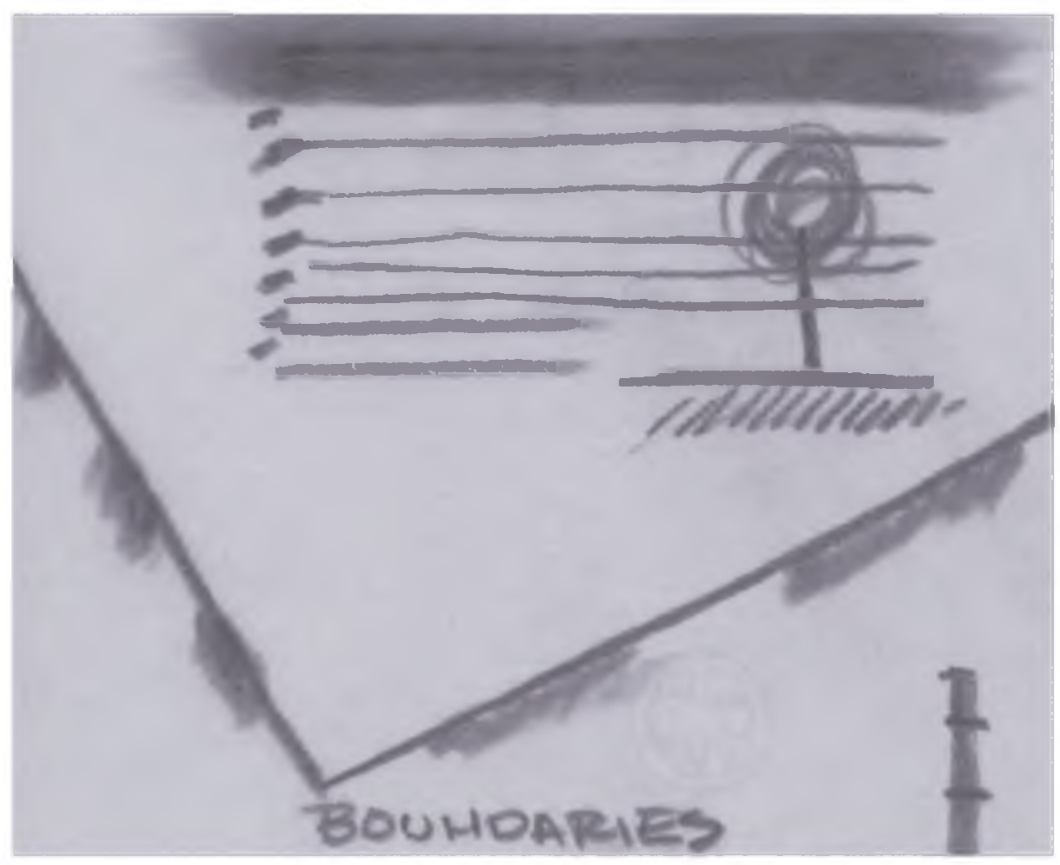

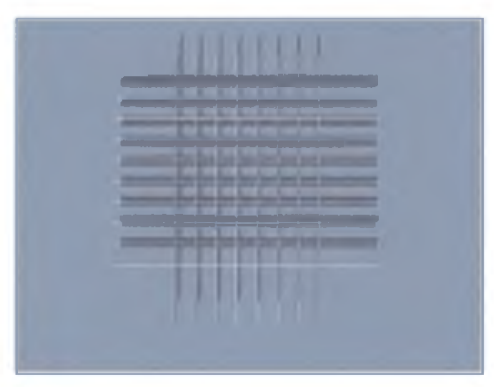
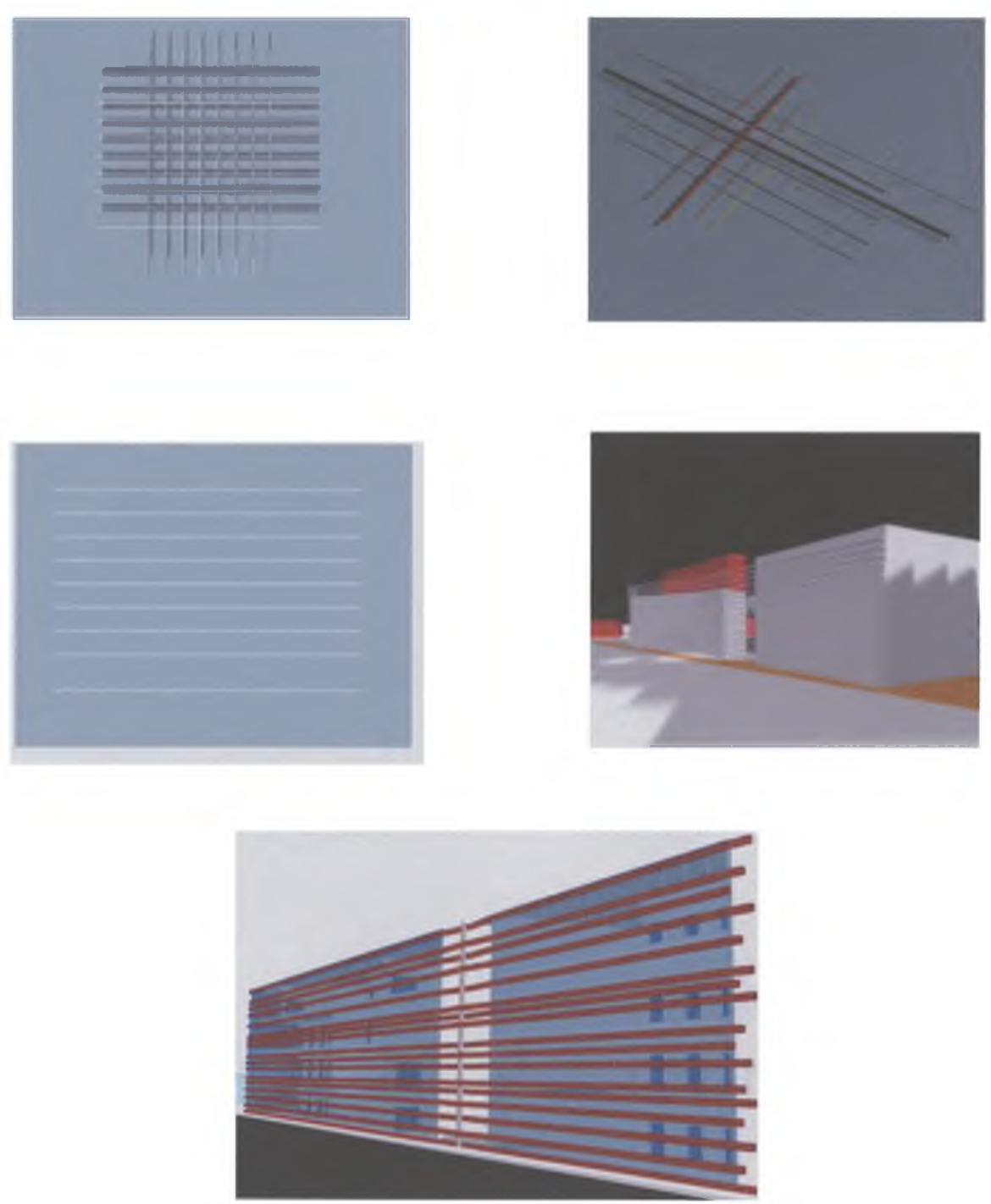

Figure

\begin{tabular}{l|l}
\hline 3 & BQUNDARY STRATEGY STUDY \\
\hline
\end{tabular} 


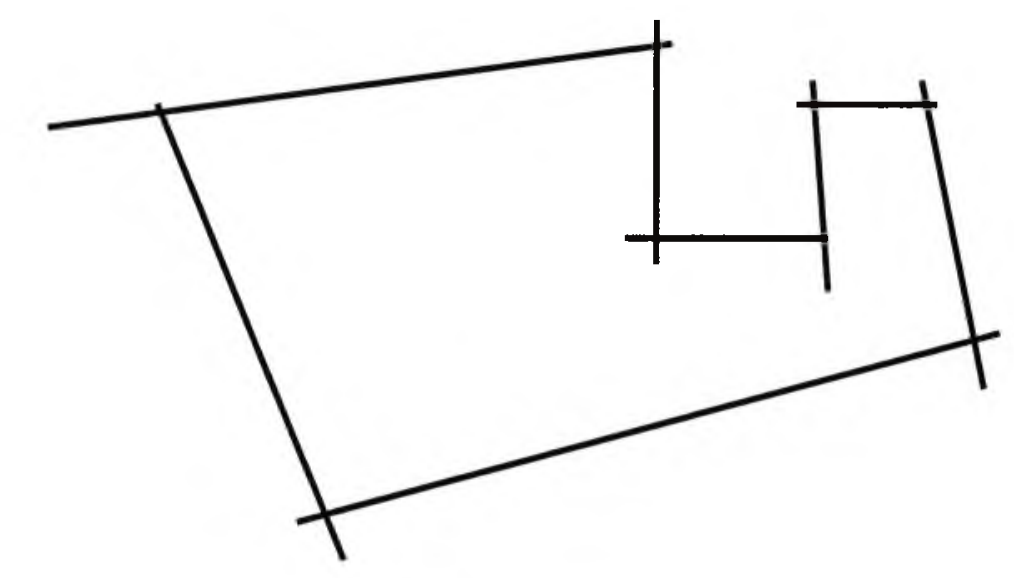

FIGURE

\begin{tabular}{|l|l|}
\hline 44 & BQUNDARY DRAWING \\
\hline
\end{tabular}

IN SUMMARY, THE BQUNDARY STRATEGY WAS APPLIED TO IMPOSE A CONTRADICTION BETWEEN FREEDOM AND PROTECTION. THIS CONTRADICTION CREATES FACADES SYMBOLIZING GESTURES IF OPENING AND CLOSING. THE SOLID BEAMS EXPRESS THE SDLIDITY AND PRDTECTION IF THE SHELTER. THEY EXPRESS THE STRONG DEFENSE against the past. HOWEVER, the glass dissqlVes the goundaries and gives

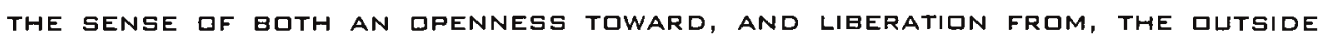
warld. the clear physical bqundaries applied to the exteridr of the BUILDING ARE GOMPLETELY DISSOLVED IN THE INTERIOR. THE GLASS SURROUNDING THE INTERIOR WALLS OFFERS THE SENSE OF UNITY BETWEEN THE FUUR PARTS OF THE

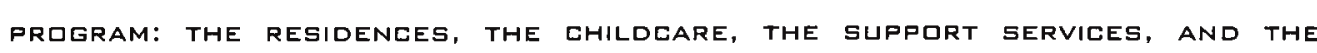
ADMINISTRATION BUILDING. BQUNDARIES FADE aWAY IN THE INTERIDR OF THE guilding as the blue glass material imparts a measure gf privacy to thIGE WALKING THRQUGH THE INTERIOR PERIMETER OF THE GUILOING. THE RESULTS OF THE
DESIGN GONFIRMED THE STRATEGY OF BOUNDARY IN A WAY THAT WAS ABLE TO BE explained considering the tWo main principles dF the design already MENTIONED PREVIOUSLY.

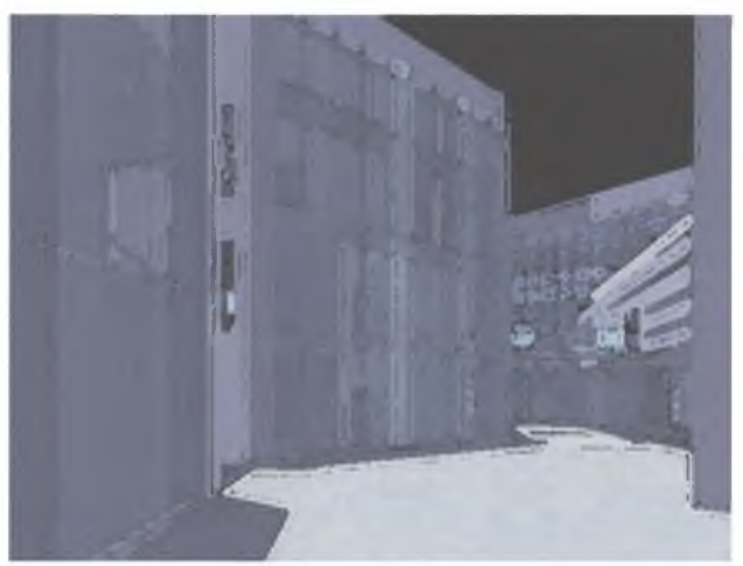

FIGURE

BIUNDARY AS INTERIOR STRATEGY

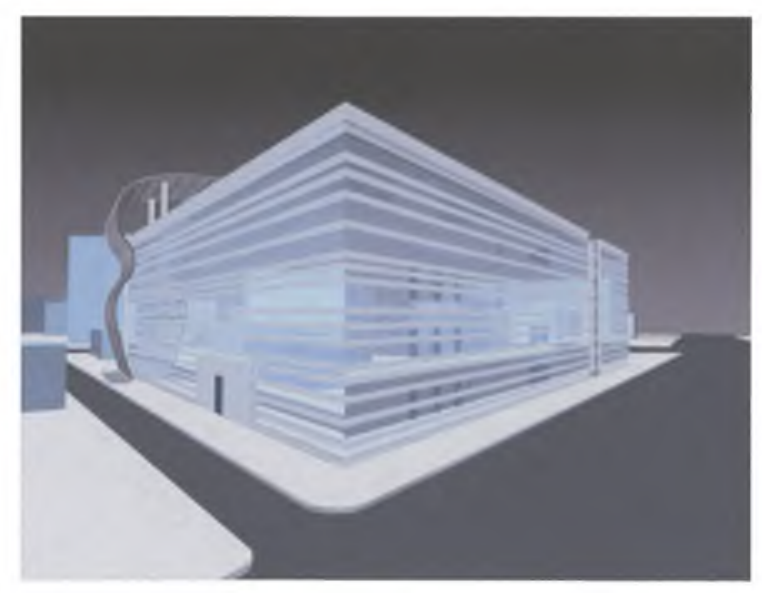

Figure

46 BUUNDARY AS EXTERIOR STRATEGY 


\section{B. Design STRATEgy II: Lighting}

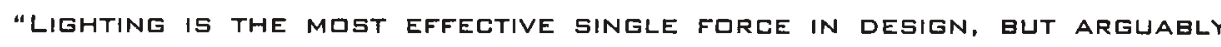
THE MOST NEGLECTED. THE ABILITY OF LIGHT TO ACCENTUATE, TD HARMONIZE, TO ENHANCE, AND TO CONVEY MOQD COULD EE PUSHED TO THE LIMITS. LIGHT IS THE POWERFUL MEDIUM THAT HAS SHAPED AND DIRECTED QUR LIVES" (NIESEWAND 19991 .

THE Lighting strategy is carried out to its maXimum eXpression. THE strategy causes the building to Virtually explode With light and is applied to almost eVery available space. Each space is described separately in this SECTION.

THE MUDERATION IF THE INCOMING LIGHT WAS DESIGNED WITH THE THIN BEAMS OF

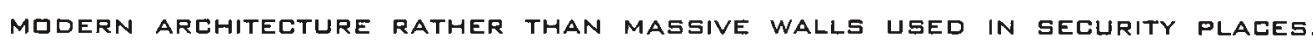
THE BEAMS NOT GNLY MIMIC THE HORIZINTALITY OF THE SURROUNDING GLILDINGS, THEY ALSI PLAY ON FIELDS DF LIGHT. THE geAMS ARE STRATEGICALLY PLACED AT EYE LEVEL BETWEEN FIVE AND SIX FEET FROM EAEH FLOUR, AS A MEASURE OF SAFETY FOR THE RESIDENTS. THE SPATIAL CONSTELLATION GF THE gEAMS GAUSES aLTERATIONS IN

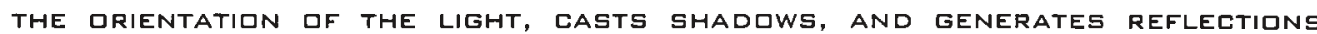
ONTO THE INTERIOR WALLS. THEY TEMPER THE MOOD OF THE LIGHT, AND GIVE DEPTH to the hallWays. THE constantly fLUCTUATING LIGHT CREATES THE IMPRESSION

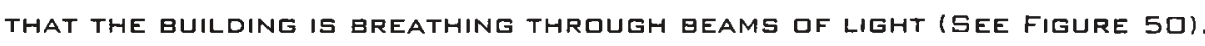

THE INSIDE SURFACES of THE STEEL, gLASS, AND GONERETE ARE DETAILED TO WORK together and create a paradoxical impressign. THE efFect gives depth ta THE Making it appears thICK through the use of beams and at the same time LIGHT THROUGH THE USE OF GLASS. THE DETAILED GONNECTIONS ARE VISIBLE FROM the interiar but nat fram the exterigr. We can see the inNer glass
STRUCTURE WHEN WALKING THE HALLWAYS BUT FROM FARTHER AWAY THE BEAMS appear to be floAtine, to the point that the glass structure seems to Disappear. THEse Walls create a commanding goundary separating the inNer AND QUTER WORLD DF THE RESIDENTS WHILE AVOIDING A FEELING GF CONFINEMENT.

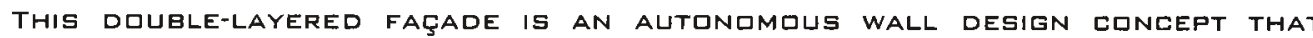
harmonizes WITH the INTERIIR AND acts as a WEATHER SKIN, DAYLIGHT MIDULATIR, SUNSHADE, WHILE ALSO PROVIDING PROTECTION (SEE FIGURE 49),

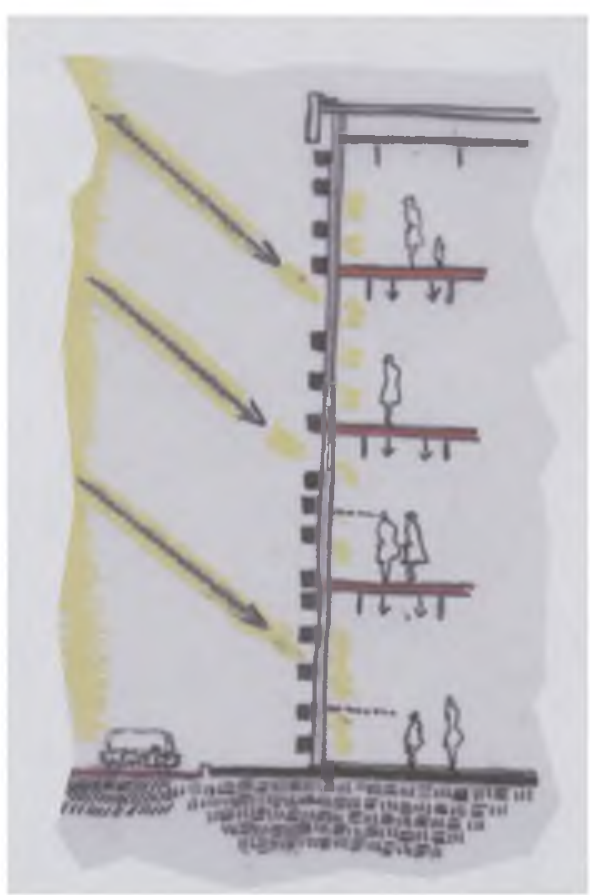

\begin{tabular}{|c|c|}
\hline Figure & \\
\hline 47 & NATURAL LIGHTING EFFEct \\
\hline
\end{tabular}




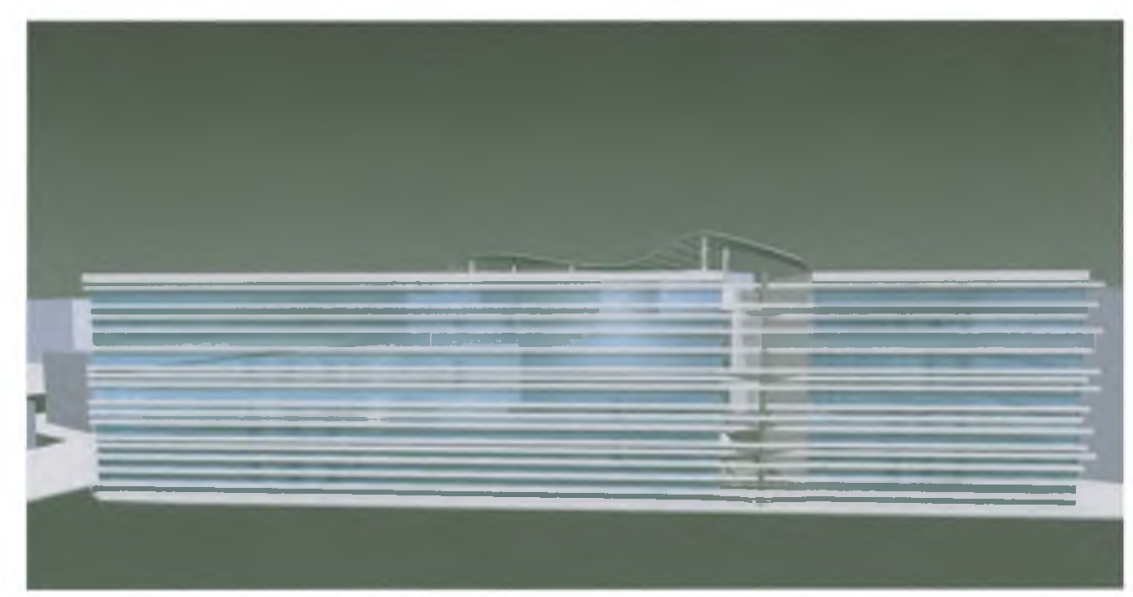

Figure

4 B East façade as lighting Strategy

INSIDE, A SYSTEM IF gLASS PANELS BRINGS LIGHT INTD THE HALLWAYS, THE MEETING rgtms, the vertical circulatign, and surfaces. The hallways are designed to seize natural light. light enters the space to create a sense gf OPENNESS. THE CENTRAL SPACE IF THE SERVICE SUPPIRT BUILDING SERVES AS AN IPEN LIBRARY, WHICH FEATURES A BOOK DISPLAY RLOM. READERS CAN CHOLSE TO mave between shadow and Light along the perimeter dF the building ISEe FIGURE 49).

IN THIS STRATEGY THE SHAPE OF THE BLILDING HAS gEEN MANIPULATED TD ALLOW THE RESIDENTS TO PHYSICALLY FEEL THE DIFFERENCES IN BETWEEN THE SPACES. IN

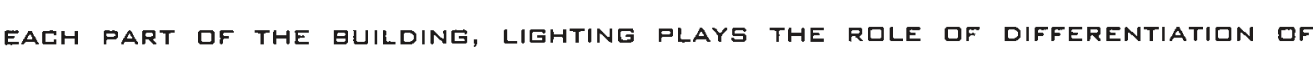
SPACES IN A WAY THAT WOMEN CAN EXPERIENCE INHAgITING A PLACE DF SUPPURT AND STRENGTH. LIGHT IS FURTHER EMPLOYED TO SURROUND THE SPAEES BY HAVING a dqugle hallway in the east component df the building. At the same time, THIS DQUBLE halLWAY CONFUSES THE PERIMETERS BETWEeN THE EXTERIOR AND THE

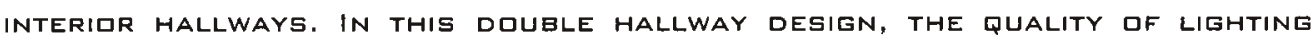
WILL BE INDISTINGUISHABLE BETWEEN SUNRISE AND SUNSET ON BOTH SIDES DF THE HALLWAY.

THE SIUTH ELEVATION OF THE GUILDING ALSO CREATES INTERPLAY GF LIGHT AND SHADE. THIS AREA HAS AN IPEN gRIDGE AND STAIREASES THAT ARE COMBINED IN A cross-type df circulation. here, we have the vertical and hurizuntal girculation regeiving natural light, creating the same lighting effect as the EAst cLADDING SYSTEM. THESE tRANSITIONAL SPACEs EXPRESS tRANSFIRMATION, TRANQUILITY, AND VITALITY IN A MODE THAT PROVIDE AN ELEMENT OF MYSTICISM.

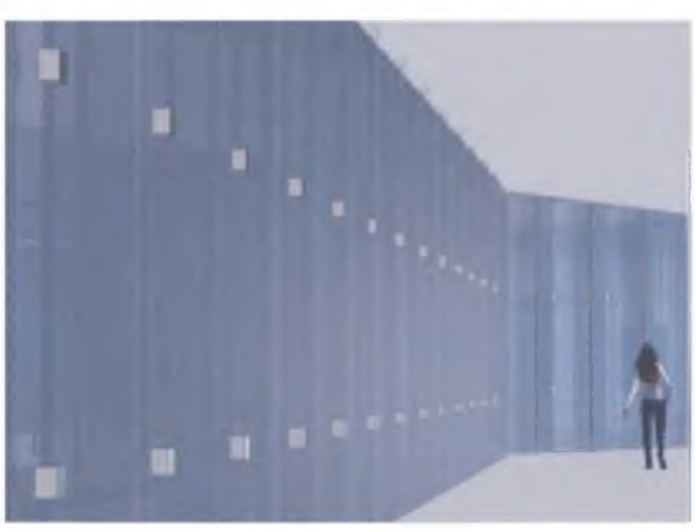

FIGURE 49 Interigr hallways as lighting strategy 


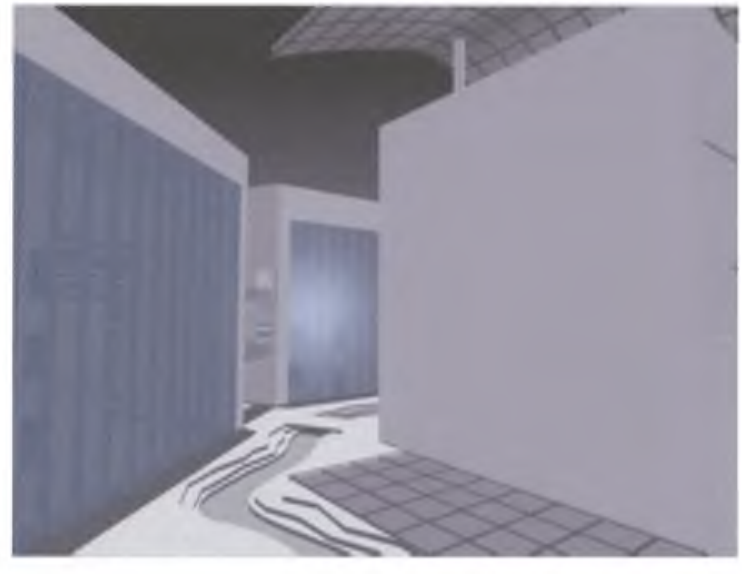

FIEURE

50

INTERIOR VIEW DF CIURTYARD

in the rogf garden, a translucent material guides the Light and reflects inta the space. THE translucent material is expressed in study MDdels (SEe FIGURE 511 .

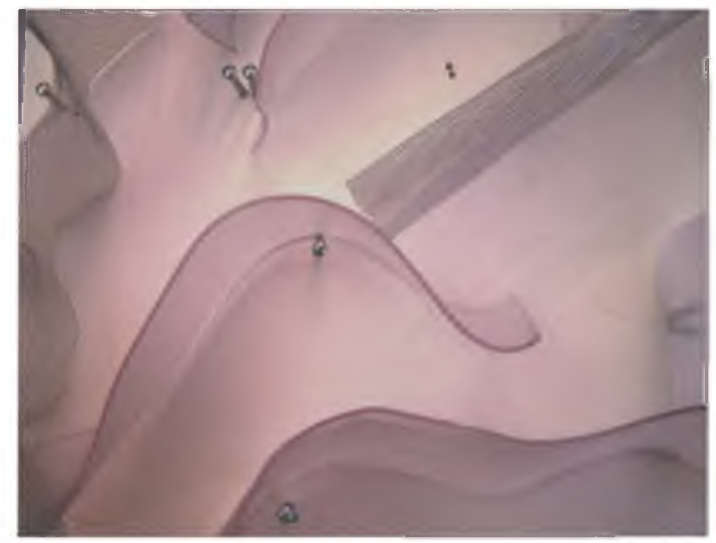

Figure

51

RIDF STUDY AS LIGHTING STRATEGY
THE ROOF FORM WAS FINALIZED GY TAKING INTO CONGIDERATION THE TRANSLUCENT MATERIAL THAT WILL PERMIT LIGHT TO COME INTD THE SPACES NOT ONLY FROM ABQVE EUT ALSO FRIM THE QPENNESS OF ITS SIDES. THIS CREATES A FULLY LIT RODFED

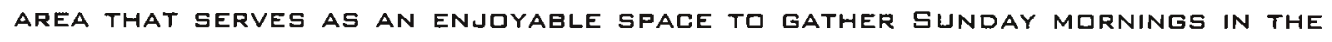
tranquiLity af THE gardens (SEe Figure $5 \mathrm{Z}$ ).

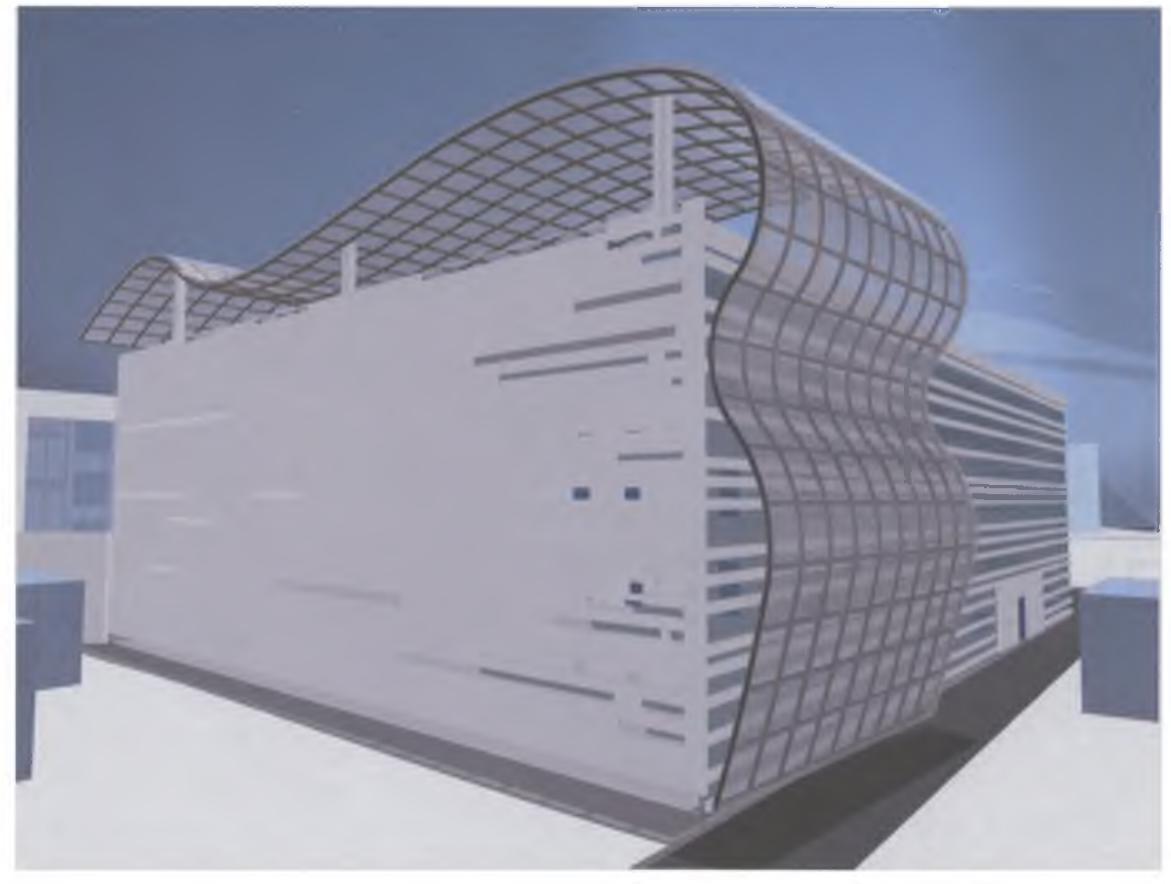




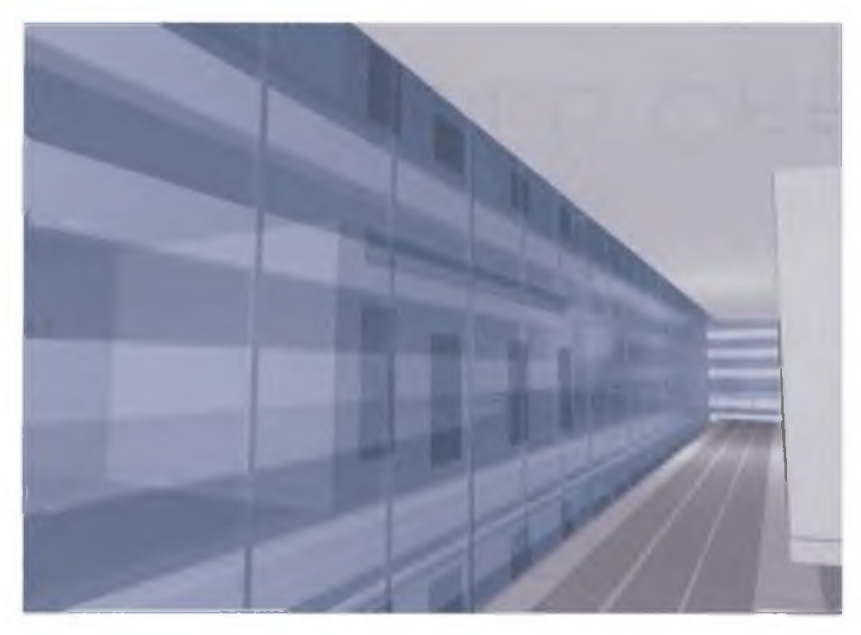

FIGURE

53 Interigr hallways as Lighting strategy

As described earlier, light breaks through the beams of the outside perimeter hallways of the building. The rays of Light themselves actually become VISible (SEe figure 53). As the light beams ARe REDIREcted, they take

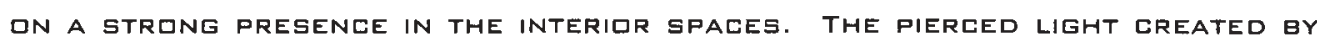
THE beAMS IS EMUTIVE AND EXPRESSIVE. THESE PIEREED SURFACES, BRDUGHT TO LIFE THRQUGH the interplaY of SHADE AND LIGHT EMPHASIZE the DEFENSE gfFered gy the WALLS to the residents. THE Lighting strategy WORKS to

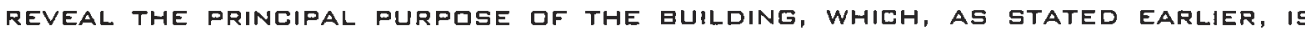
PRITECTIEN.

IN THE MEdITATION SPACES, SLIDING PAPER PANELS MADE FraM A FIBROUS PLANT called “Kouzo” diffuse the daylight entering these areas styled in the traditidnal Japanese. This arrangement allows light to pass through While safeguarding privacy. THE diffusing efFect of the paper panels tends to SCATTER THE LIGHT, SPREADING IT EVENLY QVER A WIDER AREA, APPEARING FILTERED,

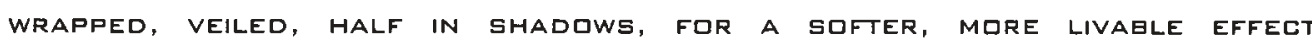
(NIESEWAND 1999). THE LIGHTING IN THIS MEDITATION SPACE IS PERVASIVE RATHER

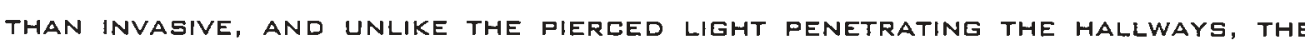

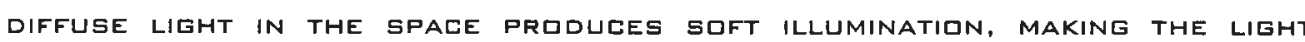
appear almast tangible (See Figure 54).

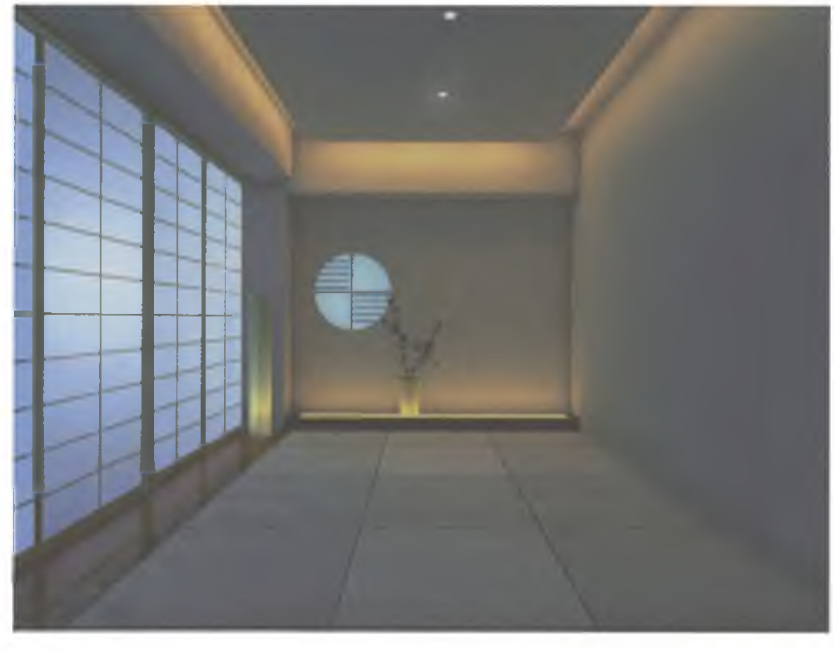

FIGURE

54 Meditation Rogm as lighting strategr

in the residences, directianal light enters the spaces and provides a natural ambiance (5ee figure 58). Daylight reaches the core of the

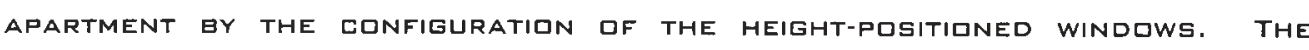
PURPQSE IS TO AVIID HAVING LIGHT ENTERED THE SPACE IN A RUSH FROM QVERHEAD, 
LIKE A WATERFALL, IT CAN GE DIFFICULT TO DISTINGUISH THE SDURCE BECAUSE OF the intensity of the illumination itself (Niesewand 1999). However, the LIGHT ENTERING THE RESIDENCES IS SDFT, LIKE THAT OF A BRIGHT AND SUNLESS SKY, AND causing the space to ge suffused in a warmer light (SEe figure 55).

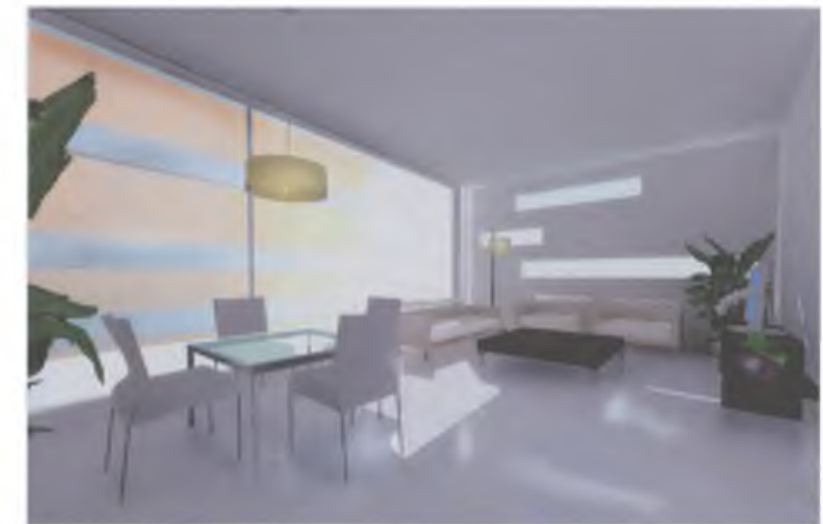

\section{FIGURE}

55 APARTMENT INTERIDRs AS LIGHTING StRATEgy

"A HQUSE SHQULD BE BUILT WITH THE SUMMER IN MIND. IN WINTER, ONE CAN LIVE ANYWHERE, BUT A PODR DWELLING IN SUMMER IS UNGEARAGLE" (NIESEWAND 19991 .

IN THE RESIDENCES THE PRINCIPLE OF “BLURRING THE BOUNDARIES WITH LIGHT" IS SEEN BETWEEN A MAN-MADE STRUCTURE AND ITS SURROUNDINGS. IN FIGURE 55 WE

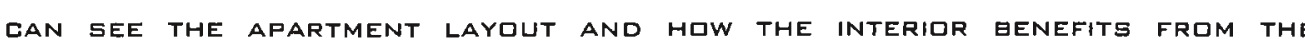
DIFFERING INTENSITY AND ANGLES OF SUNLIGHT IN THE EQURSE OF A DAY AND THROUGHDUT THE YEAR.
NATURAL LIGHTING IN THE EEDROOMS IS LIMITEO TO SMALL RECTANGULAR WINDOWS. THESE WINDOWS DO NOT PRIVIDE SUFFICIENT NATURAL LIGHTING INTO THE GEDRIOM.

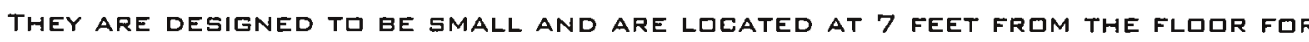

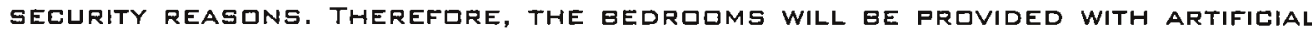
Lighting, SUeh as sconces and flogr lamps (See figure 56).
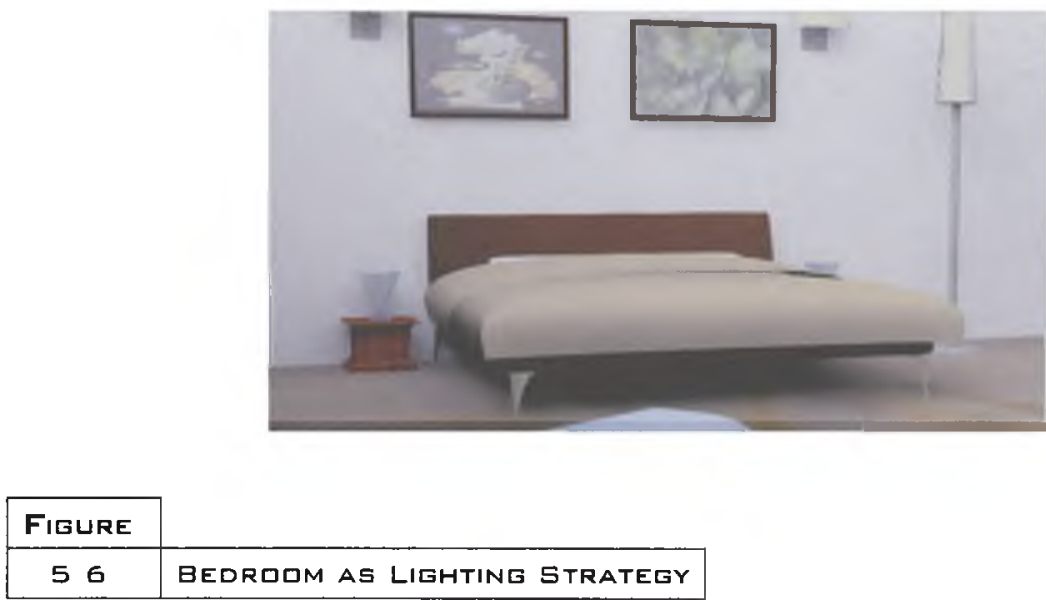


\section{Design StRAtegy III: AtTAChMEnt}

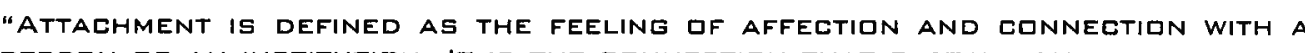
PERSON DR AN INSTITUTION. IT IS THE CONNECTION THAT FASTENS THINGS TOGETHER AND THE FAITHFUL SUPPORT FIR OTHER PARTY" (IXFORD 2QOQ).

after the application of the attachment strategy, the theory of "ATtACHMENT PARENTING" WAS EXaMINED. THIS CONGEPT WORKS PRIMARILY WITH THE MOTHER-CHILD RELATIONSHIP WHILE GIING THROUGH EXTRAORDINARY SITUATIONS. IT

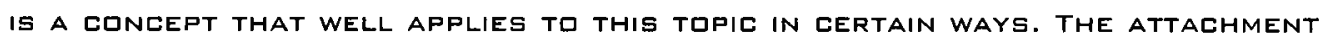
STRATEGY WAS TRANGLATED INTO A VISIGLE GESTURE.

THE FIRST PART of STRATEGY WAS TO ANALYZE THE LUCATION OF MOTHER-AND-CHILD spaces Within the facilities. Therefare, it gecame an EXPRessian of the SOLIDARITY BETWEen tHE CIMPGNENTS af THE PROGRAM: WOMEN, CHILDREN, AND

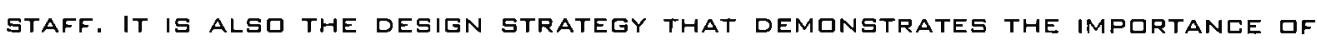
UNIFICATION AND SUPPIRT BETWEen MOTHER AND ghILD. THE MEANINGS dF

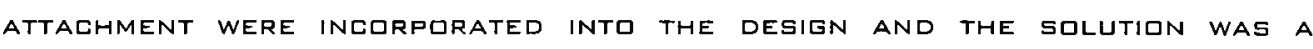

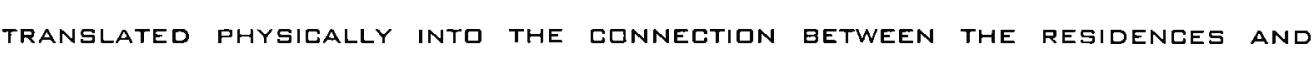
CHILDCARE. THE NEXT ELEMENT IS THE CONNECTION GETWEEN WOMEN'S SPACES AND

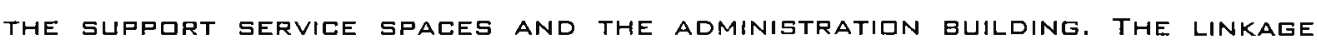
AMONG FQUR PARTS CINNECTED CONTRIBUTES TD THE FACILITATION GF INTERACTION AMONG THEM.

HOWEVER, THE atTACHMENT STRATEgy IS MOSTLY REPRESENTED Gy THE CHILDCARE

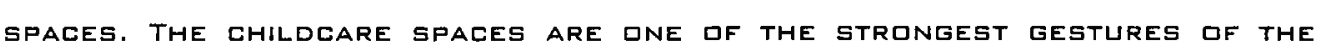
Design in Whieh the location translates the meaning of affection and CONNECTION BETWEEN THE MOTHER AND THE STAFF.

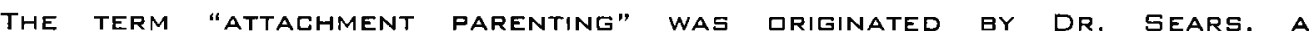
PEDIATRICIAN, FATHER DF EIGHT CHILDREN AND THE AUTHOR OF QVER 30 BOOKS ON childcare. Dr. Sears defines attaghment as fqllqws:

“ATTACHMENT IS A SPECIAL PHYSICAL AND MENTAL BOND BETWEEN PARENT AND CHILD; A FEELING THAT DRAWS YOU MAGNET-LIKE TO YOUR BABY; A RELATIONSHIP THAT WHEN FELT TO ITS DEEPEST DEGREE CAUSES THE MOTHER TO FEEL THAT THE THAT WHEN FELT TO ITS DEEPEST DEGREE CALSES THE MOTHER TO FEEL THAT THE
CHILD IS PART OF HER. THAT FEELING IS SO STRONG THAT, AT LEAST IN THE EARLY CHILD IS PART OF HER. THAT FEELING IS SD STRQNG THAT, AT LEAST IN THE EARLY
MONTHS, THE ATTACHED MOTHER FEELS COMPLETE WHEN SHE IS WITH HER BAEY AND MONTHS, THE ATTACHED MQTHER FEELS COMPLETE W
INGOMPLETE IF THEY ARE FAR APART" (SEARS 2QQD).

Dr. Sears mentions that for mathers With pergonal problems With their HUSBANDS, BEING IN HARMONY WITH THEIR CHILD IS THE MOST FULFILLING FEELING.

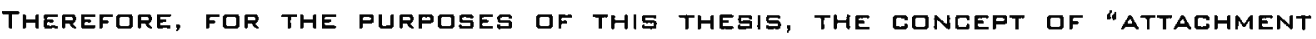
PARENTING" WILl be APPLiEd to haW Well Mather aNd EHILd are in harmany WHILE LIVING IN THE SHELTER. IT CAN THEN BE APPLIED TO ENGQURAGE WOMEN TO

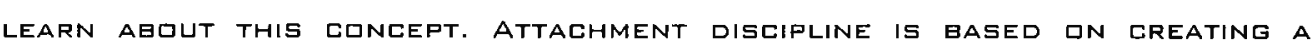

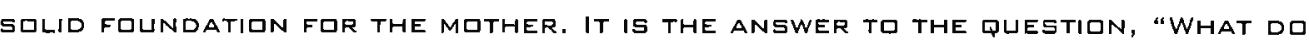
I WANT MY CHILO TO LEARN FRIM THIS SITUATION? A QUESTION VERY MUCH RELATED to the topic gf this thesis. Dr. Sears explains that a child Wha feels truly heard and understodd Will nat feel the neEd to misgehave ta gain

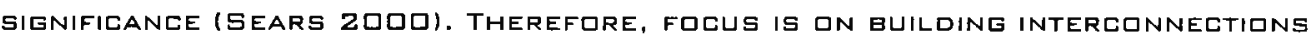
ACRISS CHILDREN'S PAST, PRESENT, AND FUTURE LIVES. 


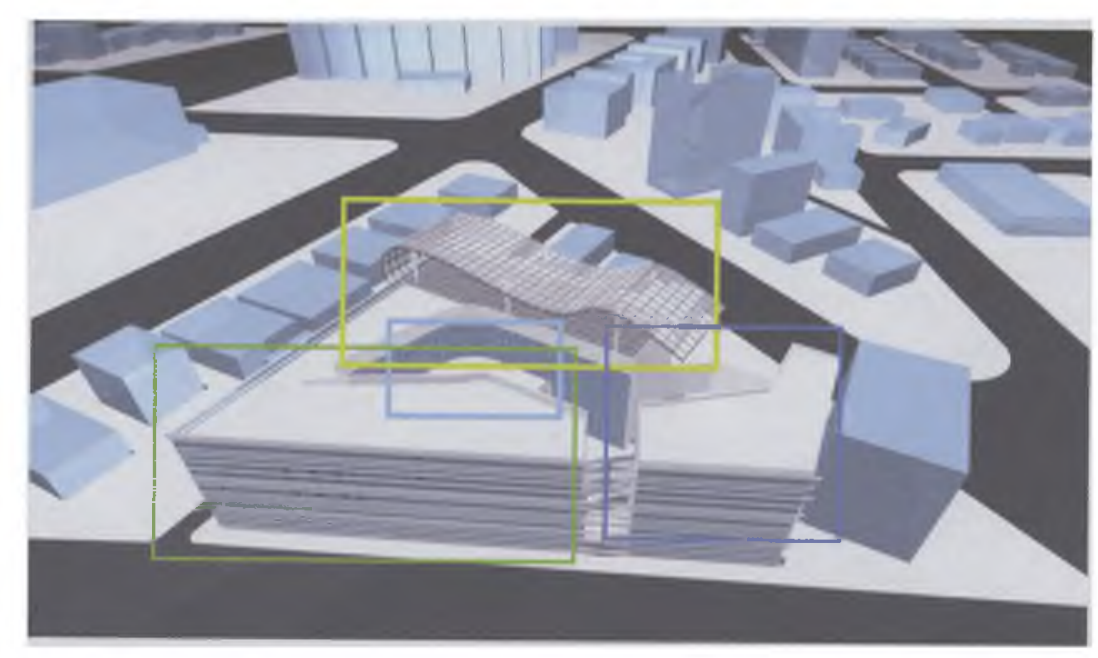

\section{FIEURE}

57 ChILdGare Location Diagramed

THE genefits of the application dF attachment parenting are highly SIGNIFICANT AND USEFul FIR THIS DESIGN STRATEgY. ATtACHING THE CHILdCARE

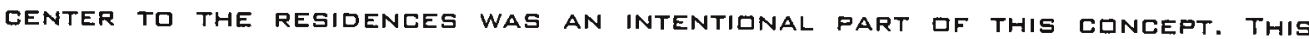

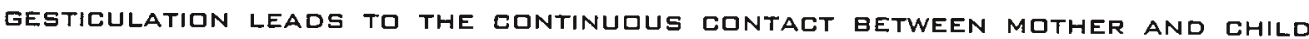
SINGE THE CHILDCARE GUILDING BECLMES PART OF THE RESIDENCES BUILDING ISEE program and flogr plans). Also, this strategy encqurages mutual giving, MUTUAL SHAPING, AND PROMOTES CONNECTION WITHIN THE PARTS. HAVING MOTHERS PHYSICALLY CLOSE TO THEIR CHILDREN GIVES THE CHILDREN NOT INLY AN INCREASED FEELING OF TRUST BUT ALSI SECURITY.

THE ATTACHMENT DESIGN STRATEGY IS SUPPIRTED GY ACTUAL RESEAREH QN MOTHERCHILD RELATIONSHIPS, AND PORTIONS OF A STUDY PERFIRMED GY DR. BELL AND DR. AINSWIRTH IN 2 IOQ ARE INCLUDED HERE. THIS STUDY REVEALS THAT MOTHER-CHILD
RELATIONSHIPS ARE INE OF THE MOST RELEVANT ISSUES APPLICAGLE TO THIS THESIS. DEVIOUSLY, THE MOTHER-CHILD RELATIONSHIP IS A CENTRAL CONSIDERATION BECAUSE WIMEN AND CHILDREN WILL BE THE CLIENTS FLR THIS AREHITECTURAL PRIJECT.

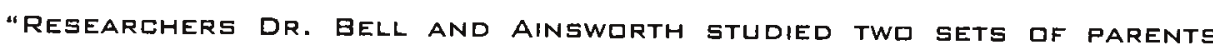
AND THEIR CHILDREN. GROUP A WAS ATTACHMENT PARENT BABIES. THESE BABIES WERE SECURELY ATTACHED, THE PRIDUCTS OF RESPONSIVE PARENTING. GROUP B BAEIES WERE PARENTED IN A MORE RESTRAINED WAY, WITH A SET SCHEDULE AND GIVEN A LESS INTUITIVE AND NURTURING RESPONSE TO THEIR CUES. ALL THESE BABIES WERE TRAEKED FUR AT LEAST INE YEAR, GROUP A THE SECURELY ATTACHED BABIES TURN OLT TO BE THE MOST INDEPENDENT. RESEARCHERS WHD GAVE STUDIED THE AFFETTS DF PARENTING STYLES DN CHILDREN'S LATER DUTEDME HAVE CONCLUDED, TD PUT IT SIMPLY, THAT THE SPODLING THEORY IS UTTER NONSENSE. PICK THEM UP OUICKLY AND THEY WILLE THETING THEORY IS UTTER NONSENSE. PIRK THEM TO QUT IT SIMPLY, THAT THE SPT DOWN QUICKLY. A CHILD MUST GO TRLULH A STALE OF HEALTHY DEPENDENCE IN ORDER TO LATER BECDME SECURELY INDEPENDENT. SPOOLING DOES BECDME AN ISSUE A FEW YEARS FROM NOW, WHEN OVERINDULGENCE SIGNALS A PARENT'S INABILITY TO SET LIMITS AND BOUNDARIES. THIS HAPPENS MOST OFTEN IN CHILD WHO IS MATERIALLY BONDED DF WHOSE PARENTS IS IN DYSFUNETIONAL MARRIAGES" (GRANJU, 1999).

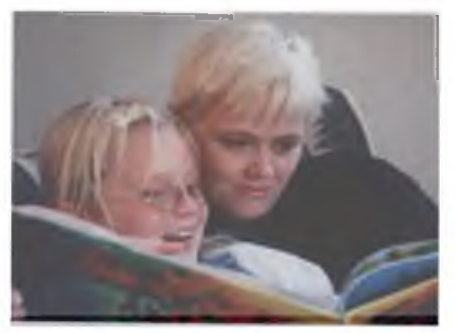

\begin{tabular}{|c|c|}
\hline Figure & \\
\hline 5 日 & WIMAN READING WITH CHILD \\
\hline
\end{tabular}

in conclusion, the attachment design strategy reflects the significant RELATIINSHIP BETWEeN MITHERs AND CHILDREN IN SHELTERs (FIGURE 6D). THE EXPERIENCE OF BEING CLISE TO EACH OTHER AIDS IN THE HEALING PROCESS DF PAST EXPERIENCES. 

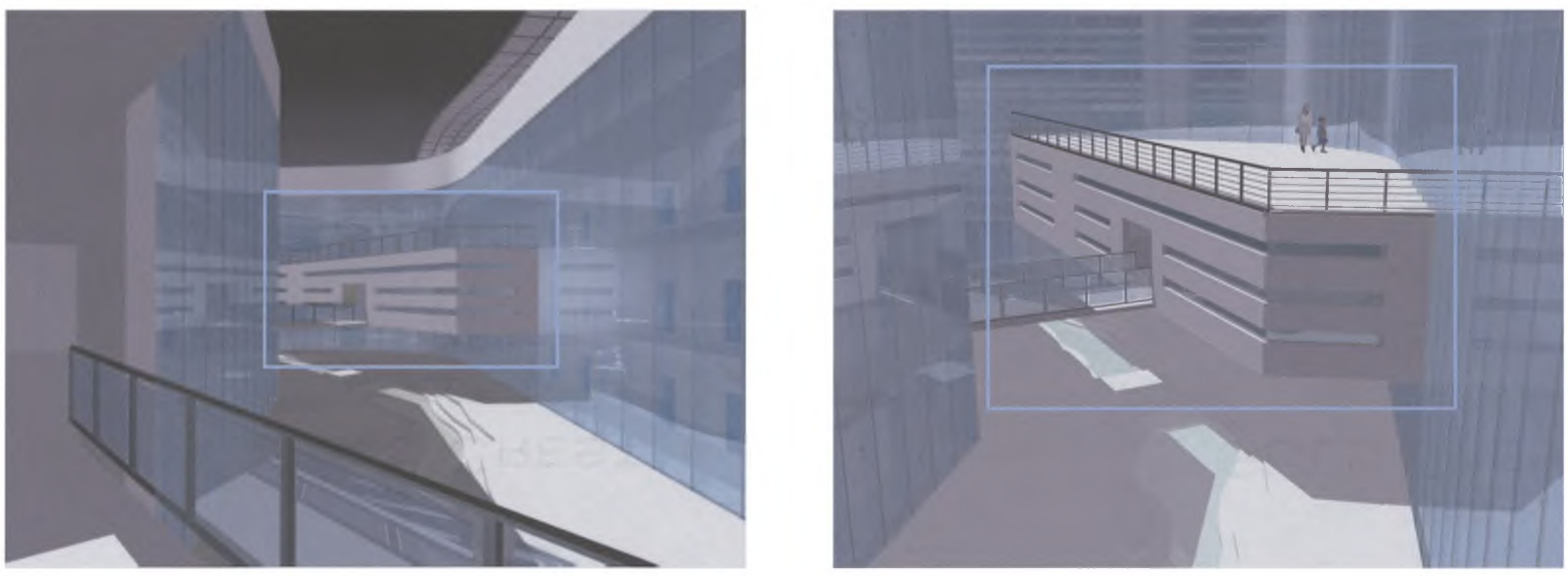

FIGURE

59 CHILDCARE LOCATION, NORTH VIEW

FIGURE

6 Childcare Location, Rogf Terrace View 

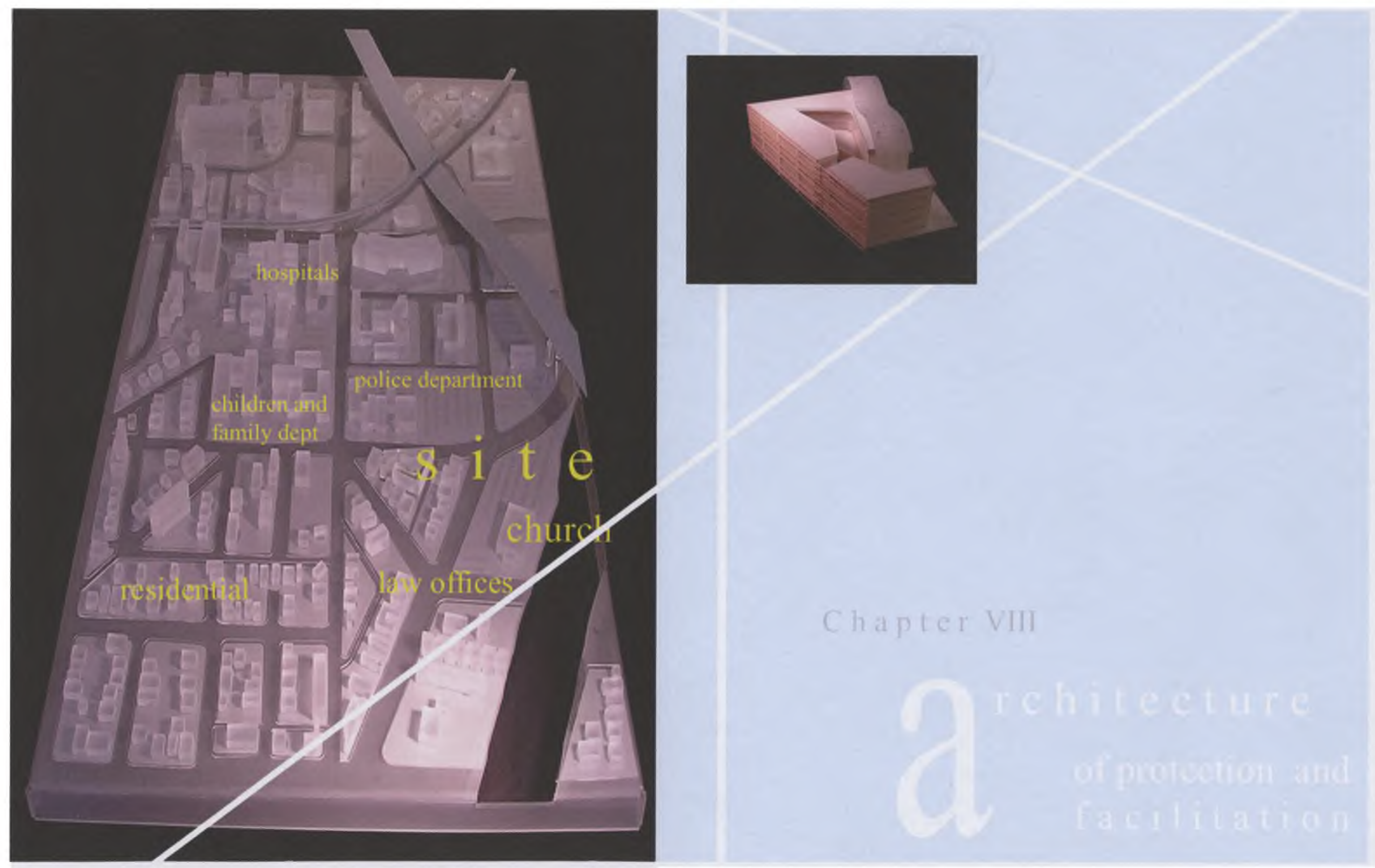
CHAPTER VIII

ARCHITECTURE FOR PROTECTION AND FACILITATION

A. STHEMATIC MODELS

EAch schematic model was guilt keEping in mind the agdVe-mentioned

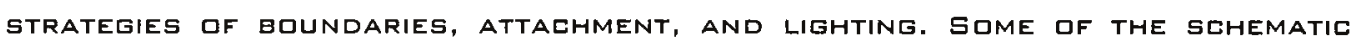
MODELS WERE FURTHER DEVELOPED AND ANALYZED. DTHERS WERE NOT FEASIBLE FOR FURTHER STEPS TOWARD COMPLETION. THREE OF THESE SCHEMATICS WERE PROPOSED AND DISCUSSED WITH THESIS cOMMITTEE.
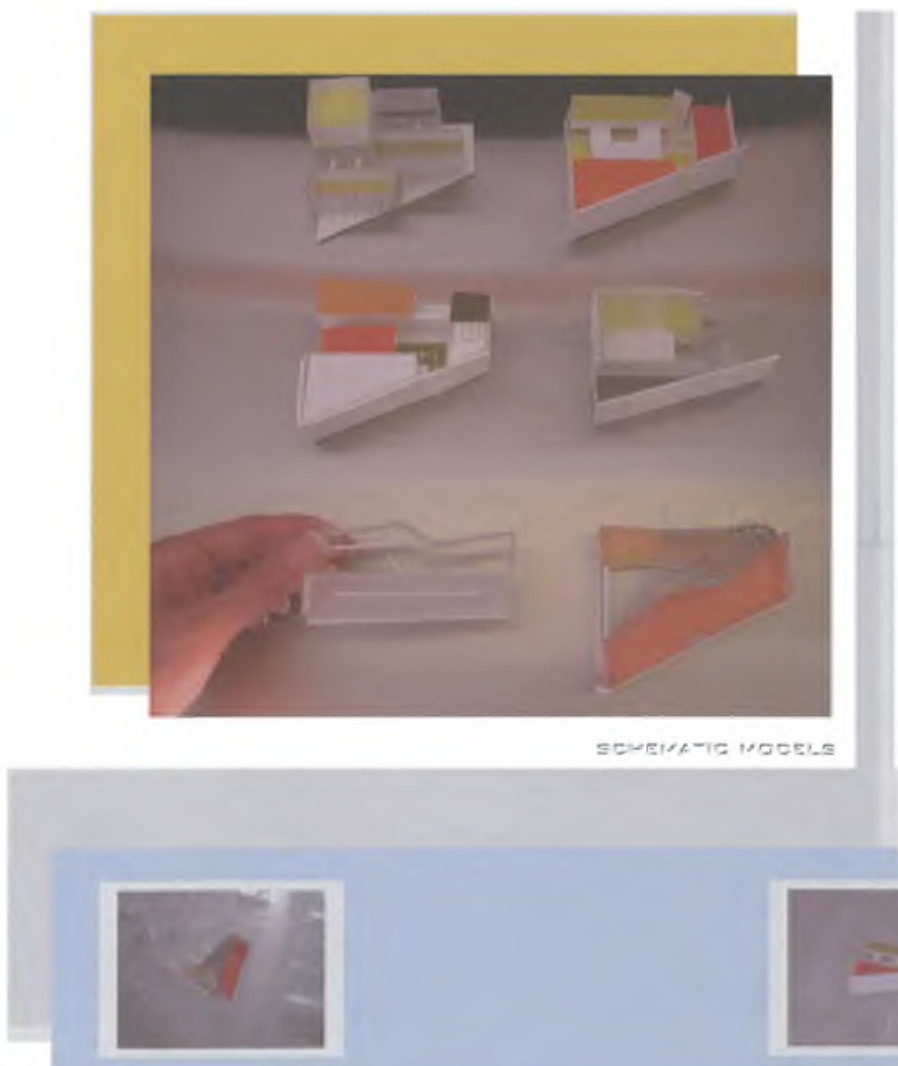

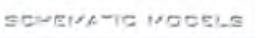
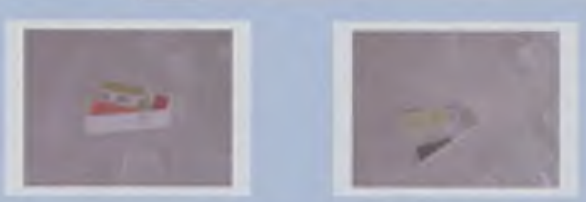

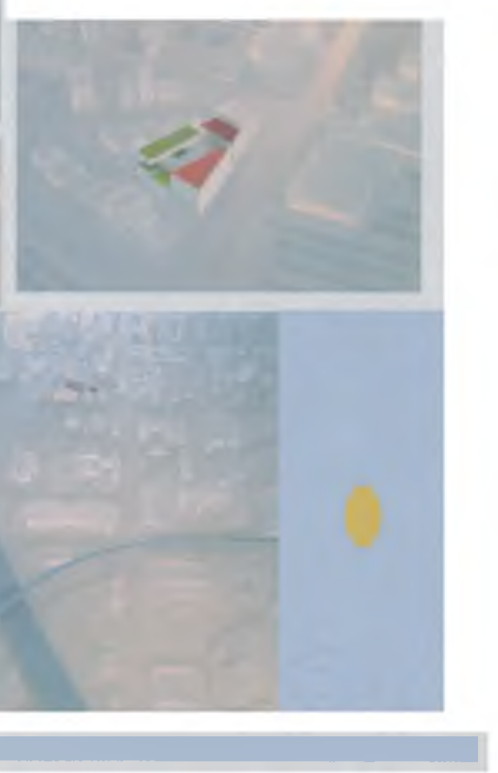

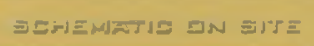

Figure

SCHEMATIC MODELS
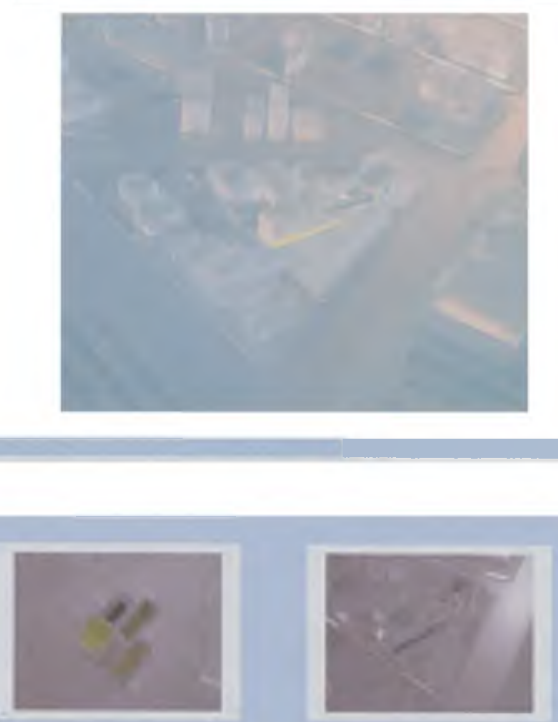
B. Project proptsals

1. PROPGSAL A

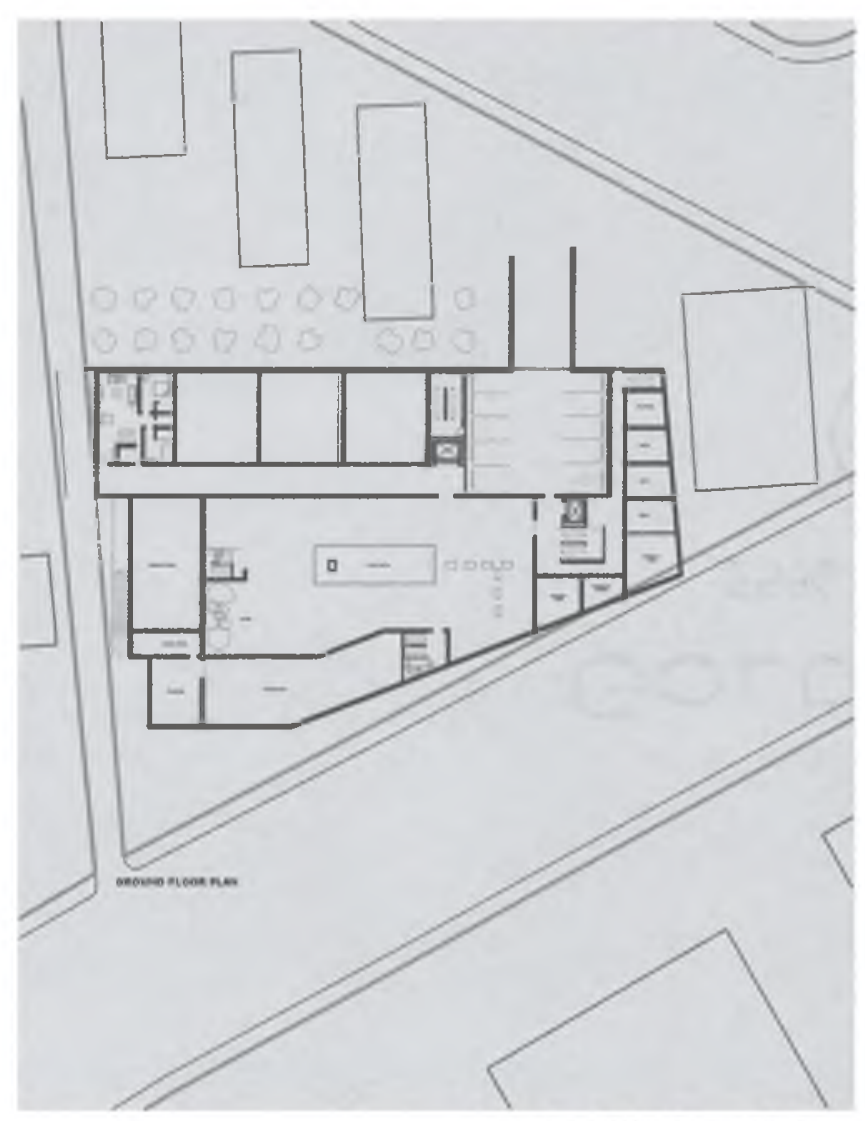

Scale $1 / 64=1^{\prime}-0^{\prime \prime}$

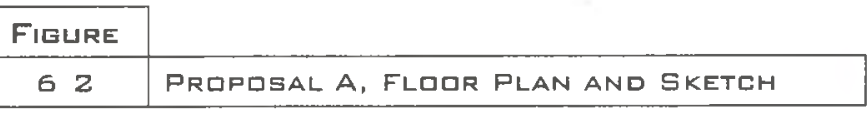

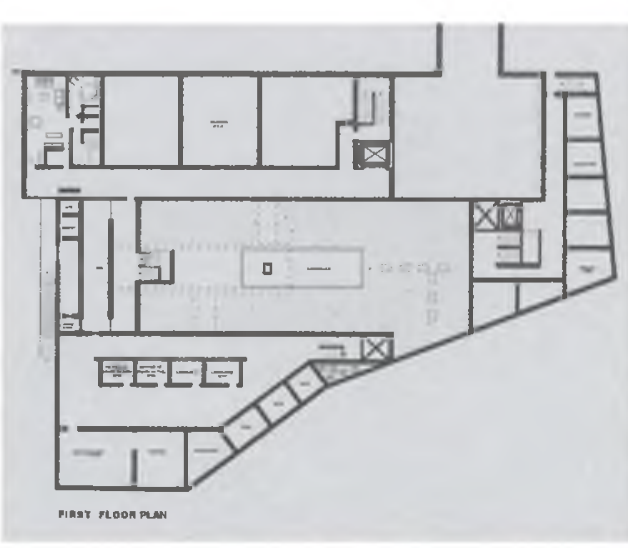
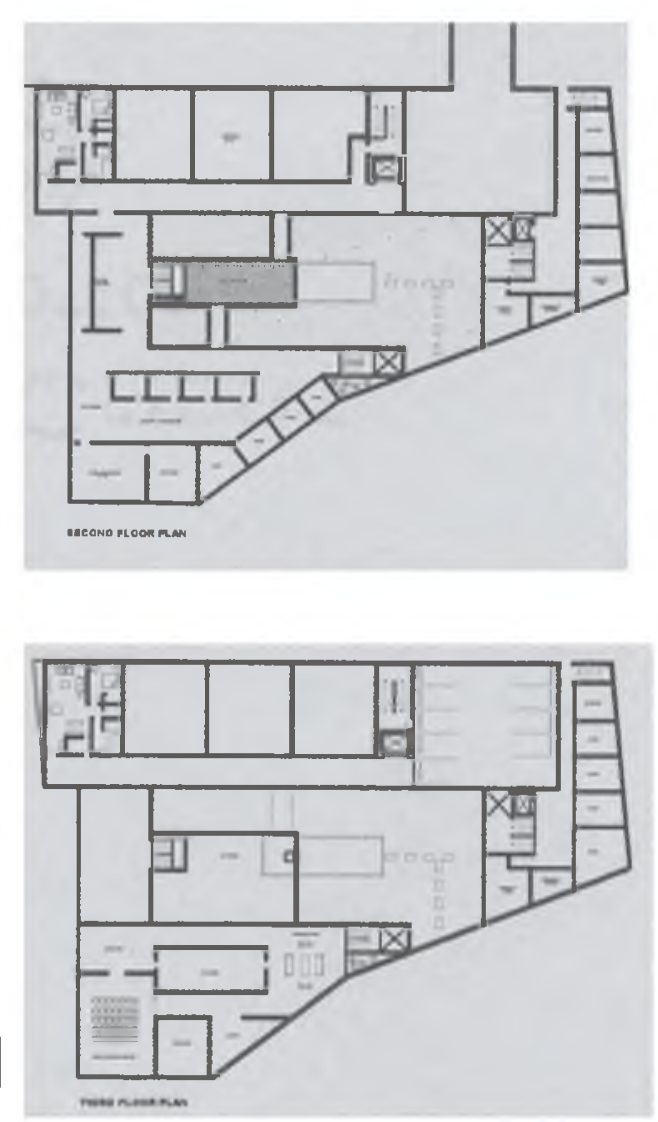

Propdsal "A" fallows the three main strategies to ge ingarparated in the guilding degign. Also, this SCHEMATIC DESIGN TOGK INTO GONSIDERATION PUELIC AND private spaces. The critique gy the cammittee oVerseeing this thesis Was that the main Volume, the

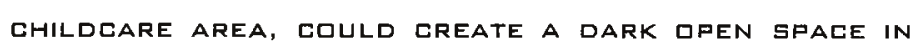
THE cENTRAL cLURTYARD. IN ADDITION, THE PARKING IS included in the main VIlume space within the BUILDING. THAT EQULD CREATE AN UNSAFE REAETION TO THE RESIDENTS SPENDING TIME IN THE GUTDOQRS GF THE BUILDING.

THE EXTERIOR FORM OF THE BUILDING DOES NIT ENGAGE

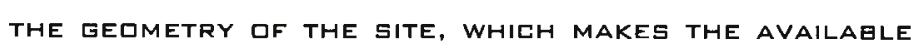
site smaller, and difficult to accommodate the LARGE PRIGRAM.

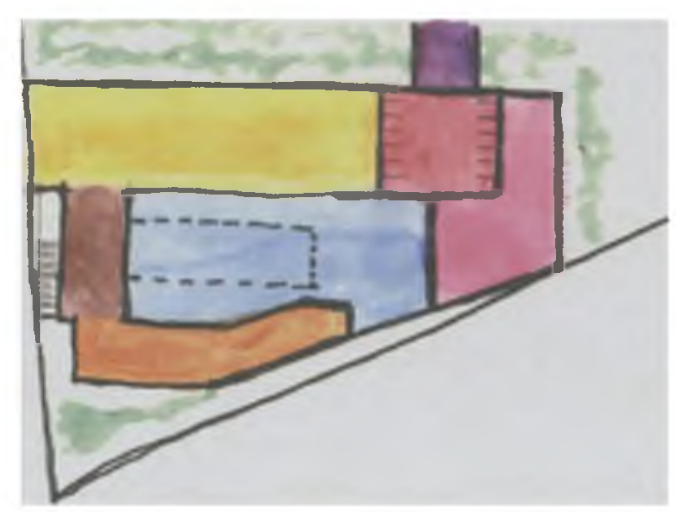



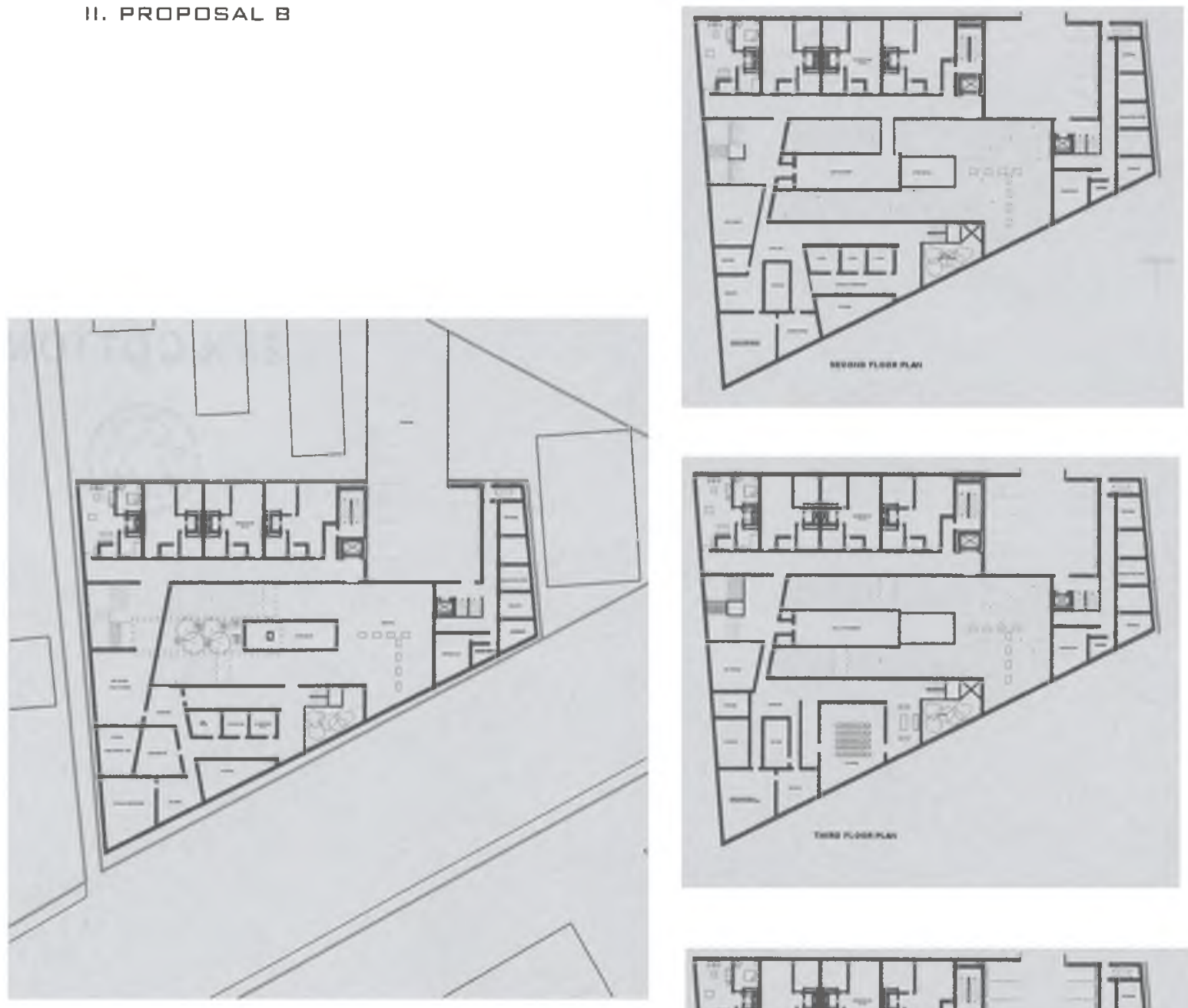

Scale 1/64 = 1'-0"

Figure

63 Propgsal B, flugr Plan and Madel
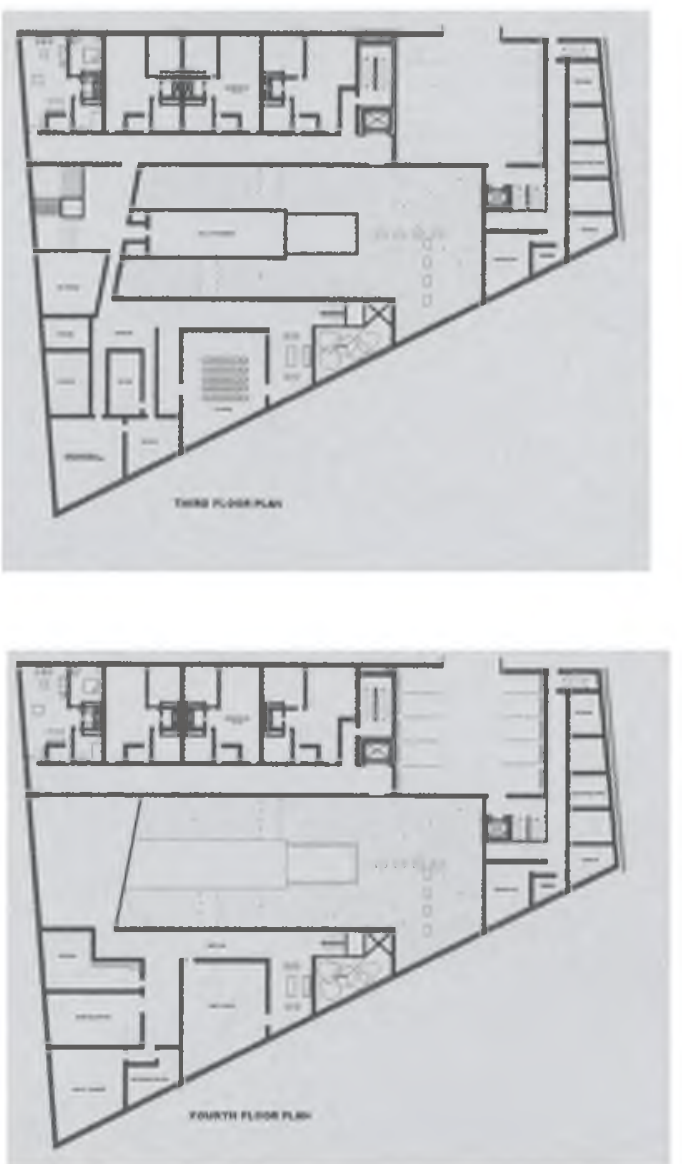

Propgsal "B" engages the site getmetry. It qceupies the site at its goundaries. The concluded design CLADDING SYSTEM WAS AN IDEA THAT CAME FROM THIS SCHEMATIC PROPOSAL. HOWEVER, PARKING SAFETy WAS

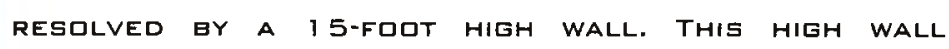
CREATES A SENGE OF CLISENESS AND DARKNESS IN THE

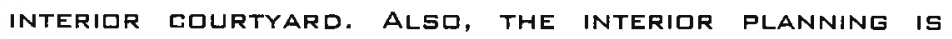
CREATING sPACES gF NON-APPARENT USE. IN THIS CASE, THE EHILDCARE LOCATION IS ALSO CREATING DARKNESS IN THE INTERIOR COURTYARD. FURTHERMORE, THE CONNECTION BETWEEN THE FQUR GUILDINGS IS NOT YET CLEARLY DEFINED IN THIS PRDPRSAL AS IT DOES IN THE FINAL DESIGN.

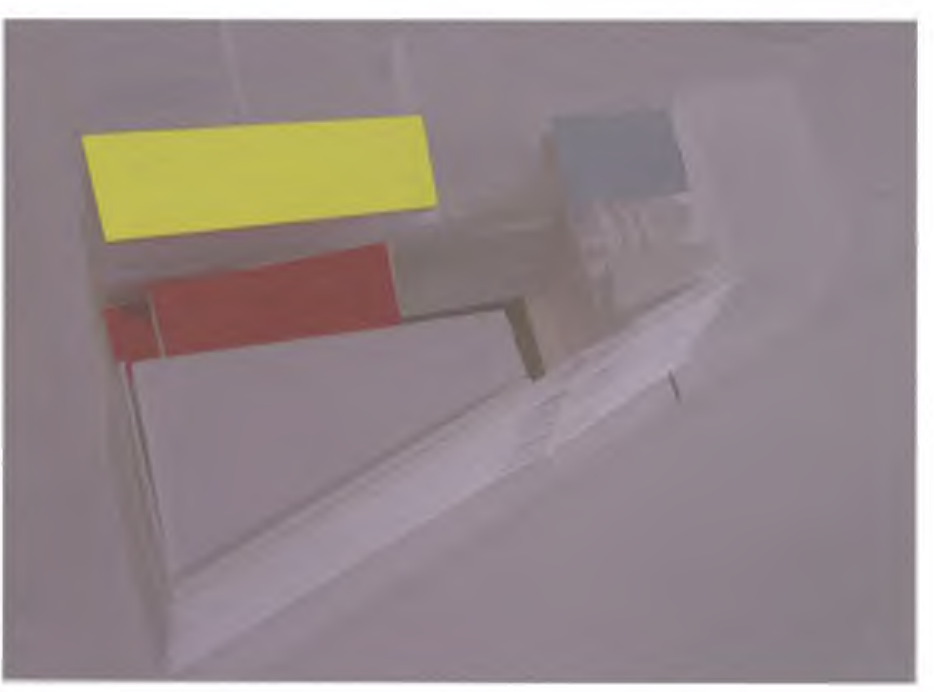


III. PROPDSAL C

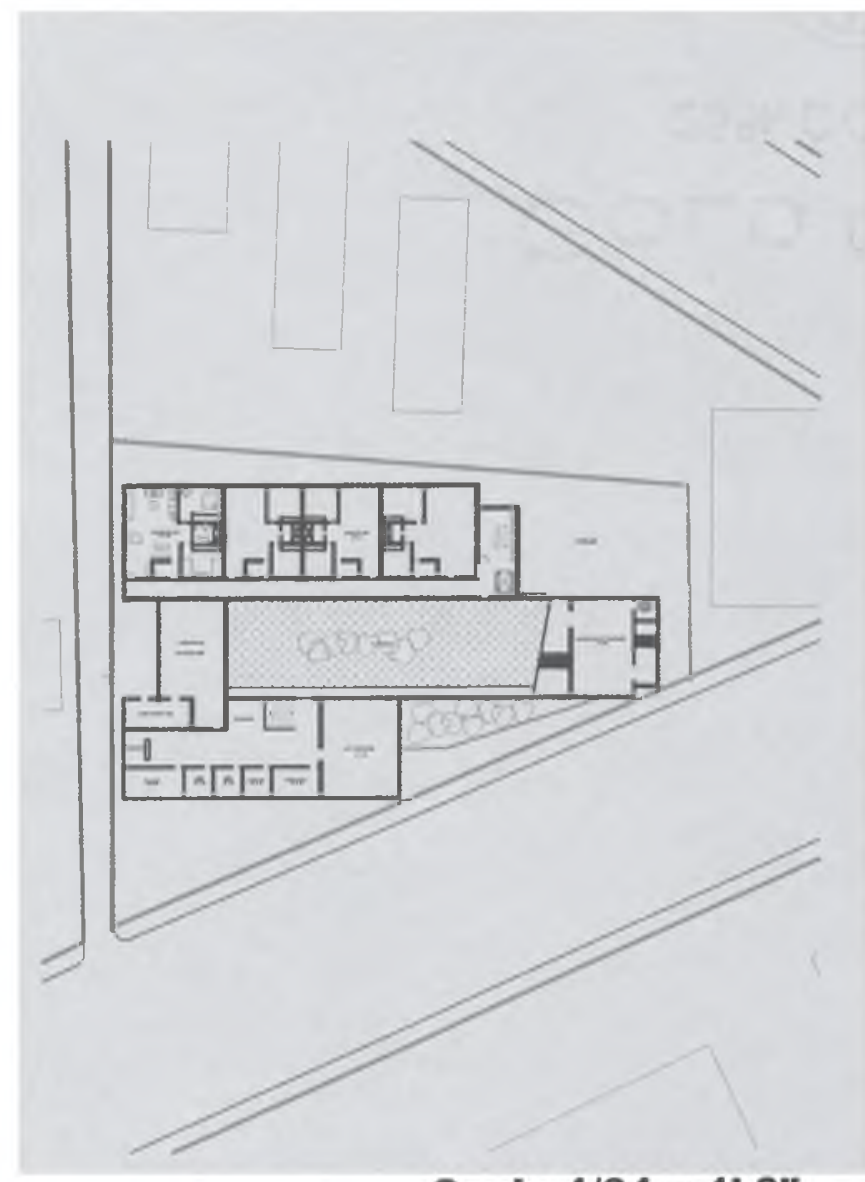

Scale $1 / 64=1^{\prime}-0^{\prime \prime}$
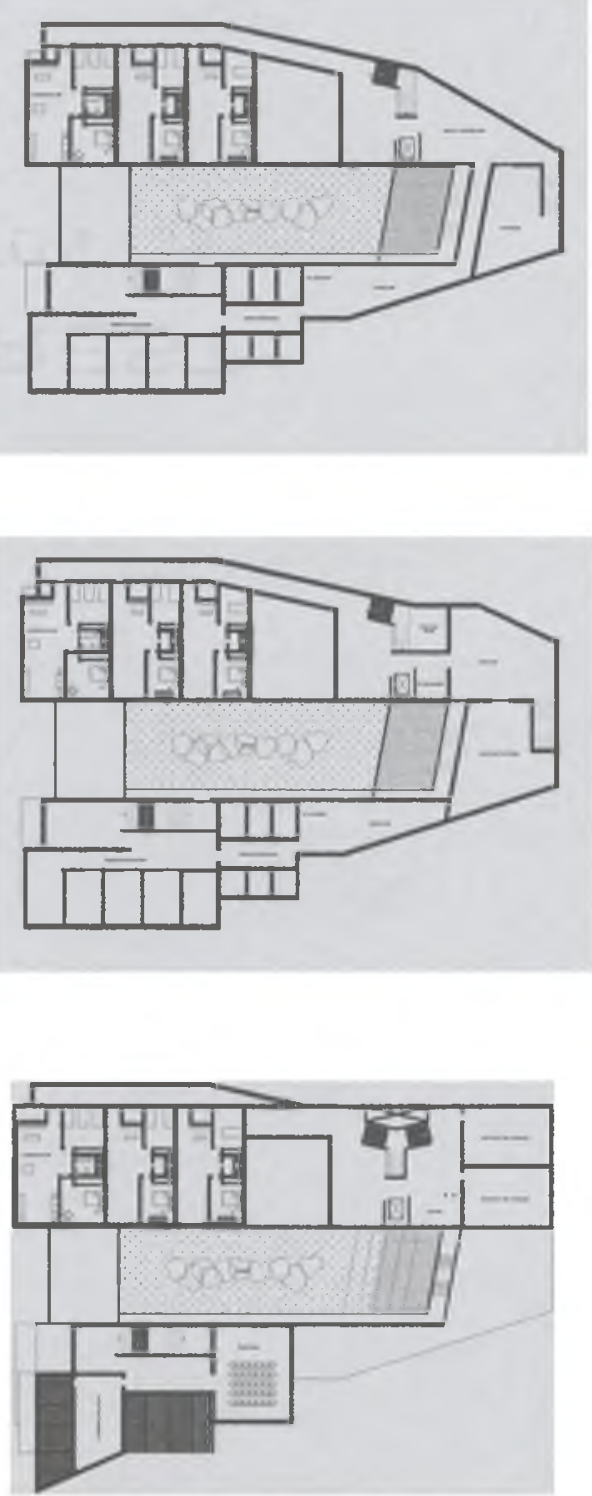

PROPOSAL “C" HAS SOME OUTSTANDING CHARACTERISTICS IN TERMS IF ARCHITECTURAL COMPISITILN. ITS SPACE planNing carries the idea gf glending the three parts dF the program. THEREFtre, the strategy of

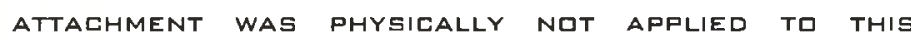
DESIGN, WHICH EXELUDED QNe gF THE STRATEgIEs AND made the propgsal difficult to Wark with. THE

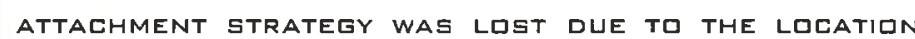
of THE CHILDCARE CENTER, WHICH IS NOW PLACED IN THE NORTH gIUNDARY DF THE GUILDING. ALSO, ANOTHER disadVantage gF this shelter design was the fagt

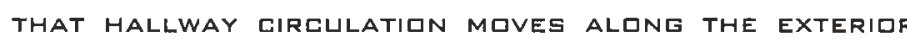
PERIMETER QF THE GUILDING MAKING THEM SOMEWHAT OF an ungafe gesticulation. Nonetheless, this degign WIULD GE PROMINENT IN THE SURRIUNDING CONTEXT EXELUDING THE DESIEN FROM FURTHER PROGRESS.

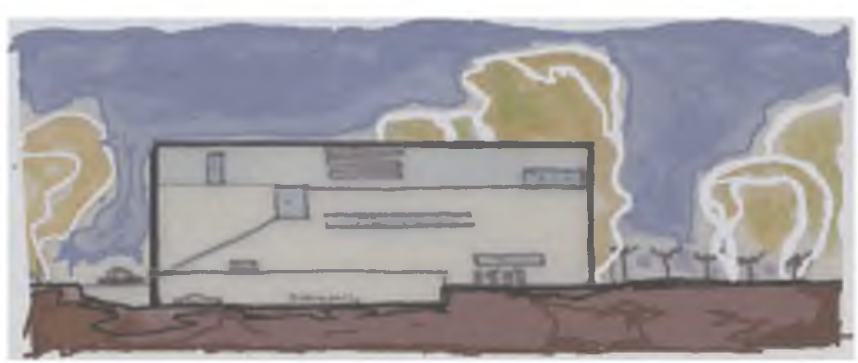




\section{c. BUILDING SYSTEM AND PROGRAM}

THE DESIGN PRIGRAM HAS THE GDAL OF ACCOMPLISHING THE QBJECTIVES OF A SHELTER tyPOLOGY DESIGN. THE PROGRAM COMPONENTS INCLUDE: RESIDENCES, CRISIS interventian, assessment, emotional support, recreation, childcare, HEALTHCARE, EDUCATION, LEGAL SERVICEs, AND ADMINISTRATIVE SUPPORT. THE FIRST Step Was to distinguish the hierarchy of spaces, the divide the private and

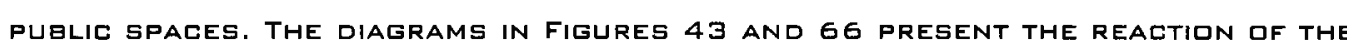
PROGRAM TOWARDS THE BUILDING SYSTEM AND SHELTER TYPOLOGY.

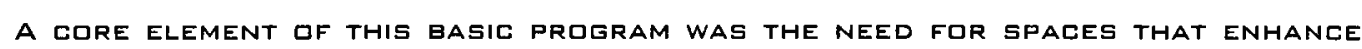
POSITIVE THINKING. IT WAS THEREFURE IMPORTANT TO INCORPORATE SPACES FOR

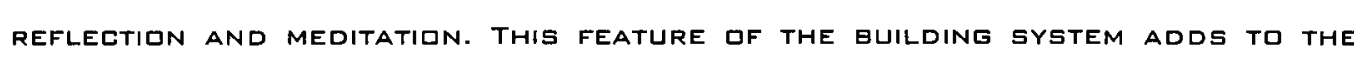
FEELING IF EMPOWERMENT FIR THE WOMEN AND CHILDREN LIVING IN THE SHELTER.

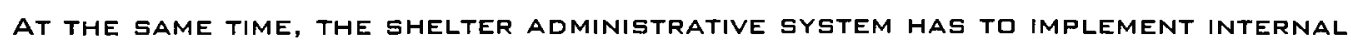
RULES FOR THE BENEFICIAL USE OF SPAEES. THE FOLLOWING LIST PROVIDES GUIDELINES FOR ASSESSING THE SAFETY OF THE SHELTER sPACEs AND PLAYGROUND. CHECKLISTS haVE BEEN ADOPTED GY OTHER SHELTERs AND CAN gE REPRINTED WITH THE PERMission of the Massachusetts Department df Puglic Health.

THE PLAYGRIUND SAFETY CHECKLIST IS A CLMPILATION OF SUGGESTED GUIDELINES BASED IN CONSUMER PRODUCT SAFETY COMMISSION GUIDELINES, INTERNATIONAL PLAYGROUND STANDARDS, AND EXPERT OPINION FROM SHELTER STAFF, AS FOLLOWS:
GENERAL ENVIRONMENT:

- security alarms on all exit dogrways

- smake detectors

- hallways have fire escape routes in clear view

- dotrs open in the direction df exit travel

- parking qutside of guillding

- exteriar treen space should be enclosed

- flogrs are smoqth with non-skid surfaces

- pipes and radiators are inaccessible to children

- Electrical cords are qut df children's reach and are kept out of dogrways and traffic paths

- medicines, cleaners, and aerosol have their own rogm inaccessible to the public

- Windows have screens stay in place when pushed

- windows can be opened only fulr inehes dr less from buttom

- trash is covered and gutside gf the facilities at all times

- the facilities are inspected for lead-based paint

- first-flogr windows have curtains to protect from external view

- children are supervised at all times

- Playground is supervised at all times and well fenced

EQUIPMENT:

- equipment and play equipment are checked often for sharp edges

- No equipment dR small endugh to fit in a eHILd's mQuth

- hinges and juints are covered

- art materials are non-toxic

- curtains, pillows, blankets, and cloth are made of flameREsistant MATERIALs

HALLWAYS AND STAIRS:

- stalrs free of edxes, toys, etc.

- the right-hand railing on stairs are at child height

- railings are present on walls

- Dogrways are closed unless this obstructs emergengy evaguation 


\section{Resident living spaces}

\section{APARTMENT UNITS \\ CLOSETS/STIRAGE}

DUTDOQR SPACES

EACH@

EACH

EACH@

Bपव Sq. FT.

Bप 5q. FT.

150 SQ FT.

18, BSD Sq. FT.

II. Child care center

\section{CHILD CARE RIDM}

STORAGE

1,Bपव Sq. FT.

DiNING RLOM

KITCHEN

RESTROOMS

GUTDODR PLAY AREA

TOTAL Sq. FT. WITHOUT EIREULATION

1,800 Sq. FT.

111. SERVICE AND SUPPIRT BUILDING

SECURITY ENTRANCE

SECURITY CAMERA ROIM

HOLDING LOBBY

VISITORS MEETING ROOM

HEALTHCARE

NUTRITIONIST'S DFFICE

CHILDREN'S COUNSELOR'S DFFICES

CHILDREN'S COUNSELING ROIM GROUP

CHILDREN'S COUNSELING RIOM
WIMEN'S CQUNSELOR'S DFFICES

WIMEN'S COUNSELING ROOM GROUP

Physialogist's DFFICE

STORAGE

TELECOM ROIM

TV SOCIAL AREA

VOLUNTEER'S DFFICES

CLASSROOM

TEACHER'S DFFICE

MEDITATION ROIM GROUP

MEDITATION RIOM SINGLE ROIM

MULTI PURPOSE ROOM (ACTIVITIES)

WOMEN'S RESEARCH CENTER

INDOQR PLAY RIOM

TOTAL 5q. FT WITHOUT CIRELLATION
160 SQ. FT.

180 SQ. FT.

3०ם 5q. FT.

48D SQ. FT.

$150 \mathrm{SQ}$. FT.

150 SQ. FT.

730 SQ. FT.

73ם SQ. FT.

350 SQ. FT.

150 SQ. FT.

65 Sq. FT.

650 5Q. FT.

620 5q. FT.

150 SQ. FT.

680 5q. FT.

255 5Q. FT.

5505 5. FT.

480 SQ. FT.

$55054 . \mathrm{FT}$.
690 SQ. FT.
IV. ADMINISTRATION BUILDING

\begin{tabular}{|c|c|c|c|}
\hline 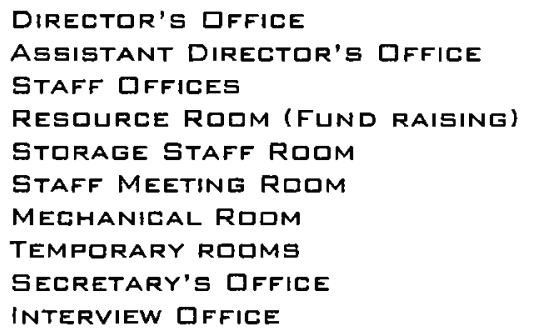 & $\begin{array}{l}2 \\
2 \\
8 \\
2 \\
2\end{array}$ & $\begin{array}{l}\text { EACH@ } \\
\text { EACH @ } \\
\text { EACH@ } \\
\text { EACH } \\
\text { EACH@ } \\
\text { EACH } \\
\text { EACH@ } \\
\text { EACH@ } \\
\text { EACH@ } \\
\text { EACH@ }\end{array}$ & $\begin{array}{l}150 \text { Sq. FT. } \\
100 \text { SQ. FT. } \\
100 \text { SQ. FT. } \\
150 \text { 5q. FT. } \\
150 \text { SQ. FT. } \\
200 \text { Sq. FT. } \\
170 \text { Sq. FT. } \\
160 \text { Sq. FT. } \\
150 \text { Sq. FT. } \\
288 \text { Sq. FT. }\end{array}$ \\
\hline
\end{tabular}

total square fogtage Without circulation

..3, $17854, F T$.

v. Transitional spaces

Elevators, stairs, hallways

GATHERING SPACES

WAITING/SITTING AREAS

VI. Site LINSIDERATIONS

PARKING

20 SPACES

PrgGRAM SUMMARY:

RESIDENTIAL BUILDING

SERVICE AND SUPPORT BUILDING

8,500 5q. FT.

SERVICE AND SUPPIRT BUILDING $\ldots \ldots \ldots \ldots \ldots \ldots \ldots, 670 \mathrm{SQ}$. FT.

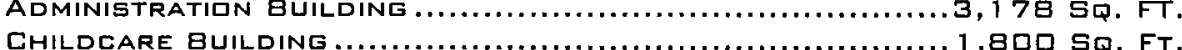

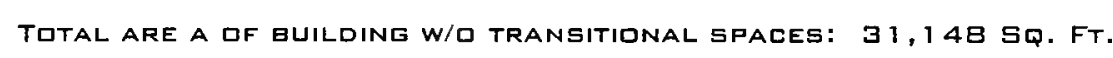




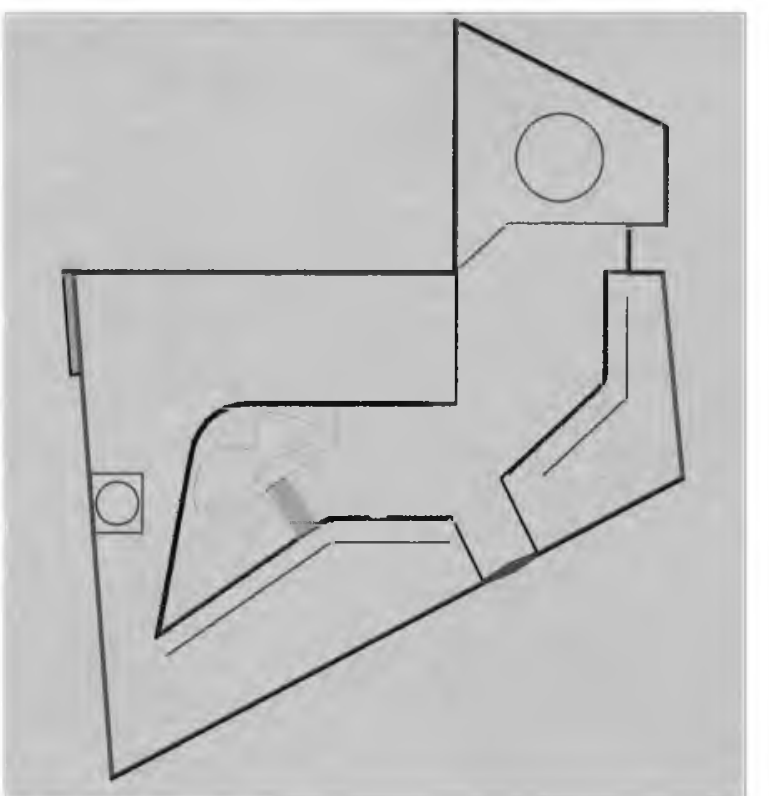

PROTECTION

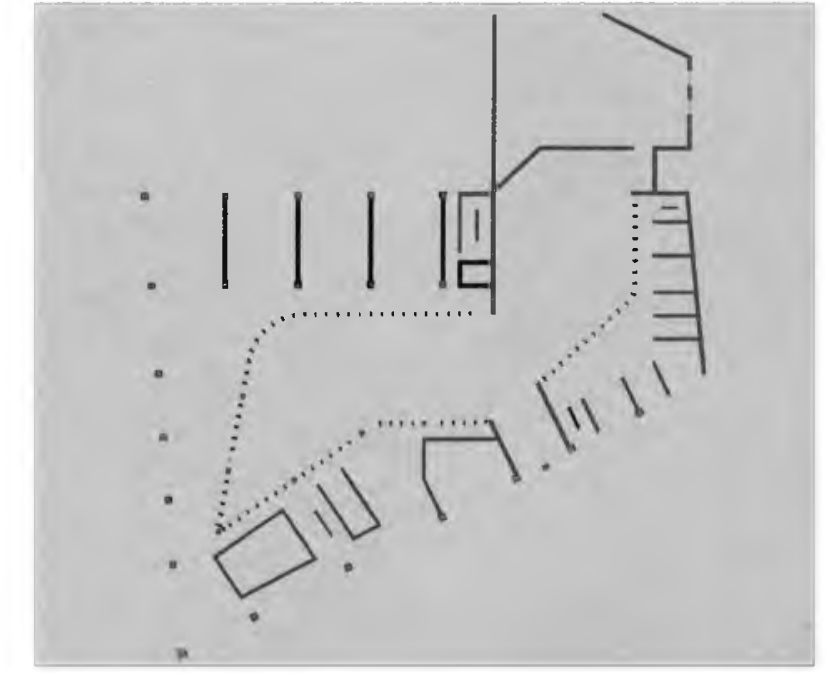

STRUCTURE

\section{Figure}

65 Descriptive QVerview Diagrams
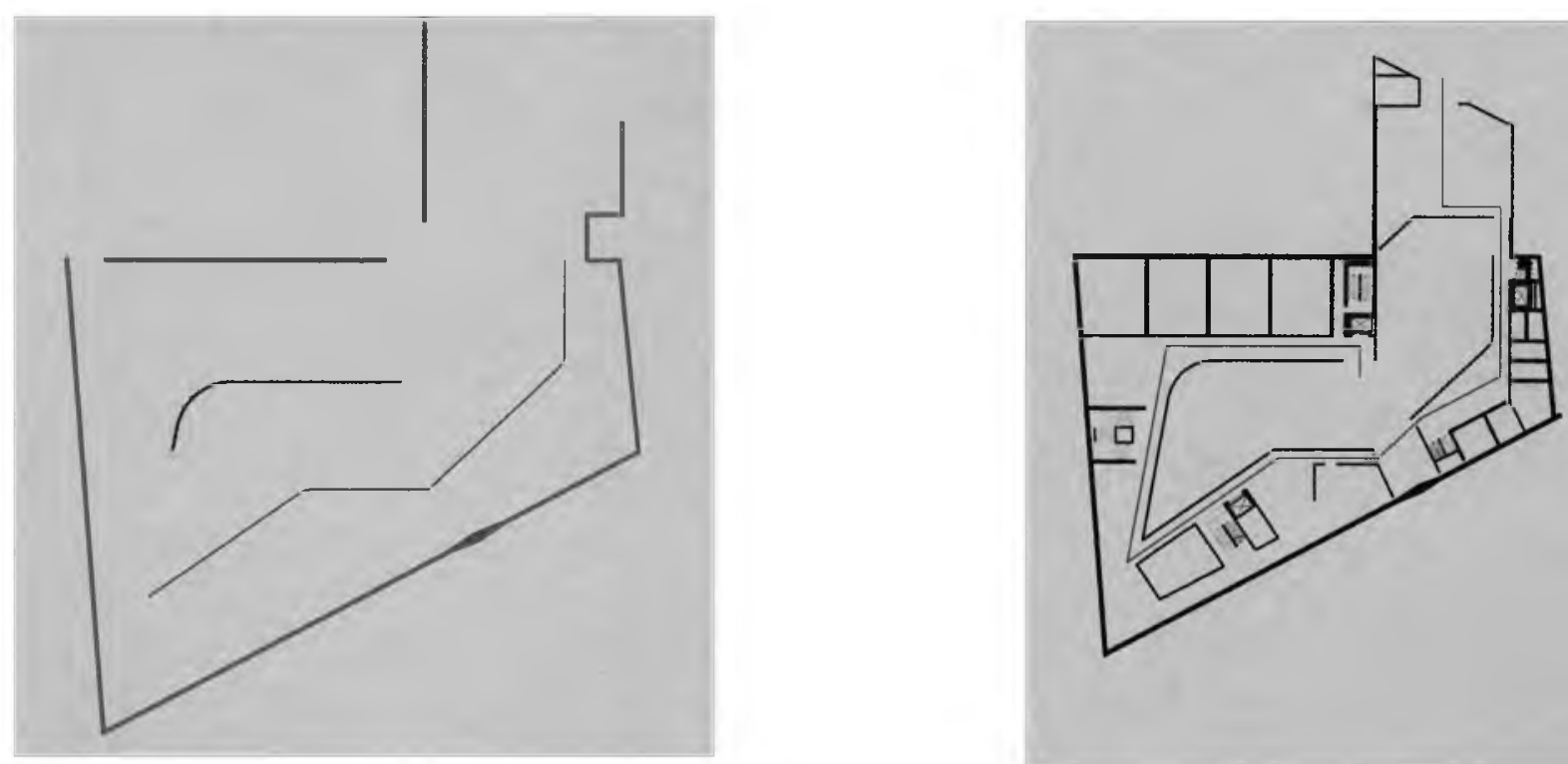

GEOMETRY

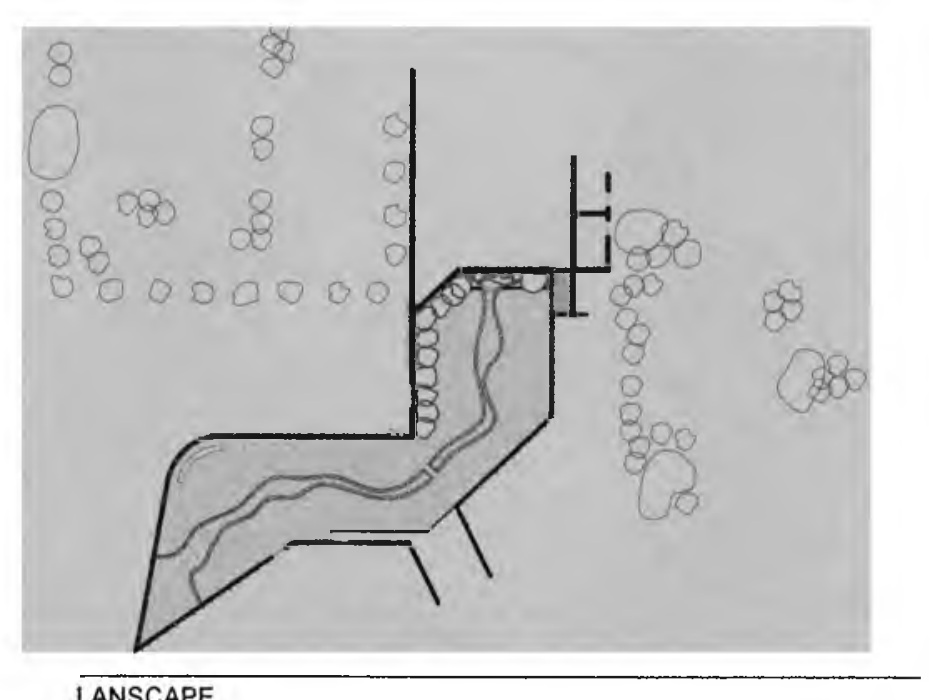

LANSCAPE

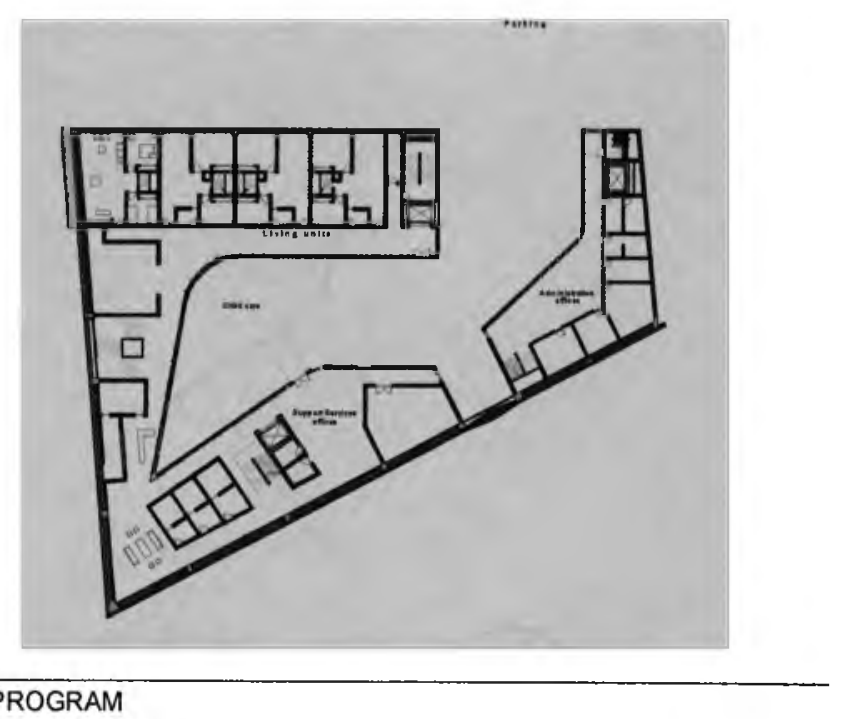




\section{DESCRIPTIVE QVERVIEW}

THE BUILDING is URgan IN GHARACTER. EXTERNAL characteristics give the qualities of pureness, and cleanness in a simplified, minimalist design. Thin geams portray a sense gf protection With a subdued tone, as they cLad the BUILDING'S EAST AND SOUTH FAÇADES, CREATING A MQNOLITHIC AND POWERfuL

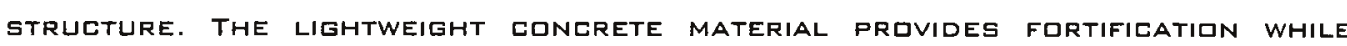
INDUEING A PEREEPTION IF STRENGTH IN THE BUILDING. IN ADDITION, THE GLEAN LINES PRDOUCED GY THE gEAMs TRULY PLAY UP THE NATURAL LIGHTING, BREATHING LIFE INTO THE structure (5Ee Figure 66).

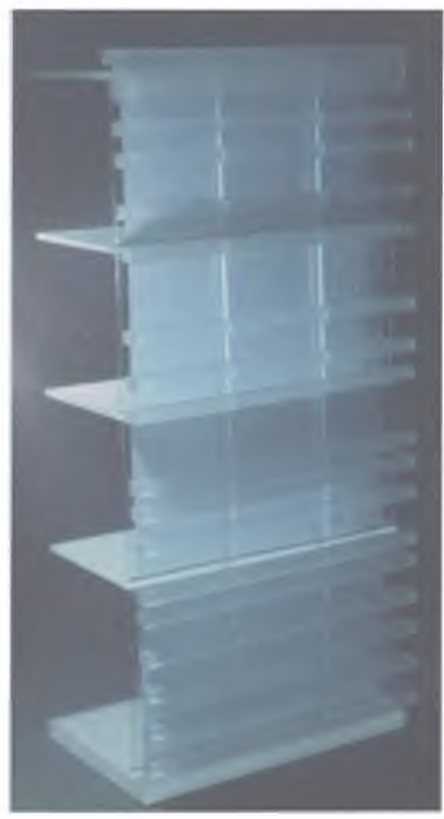

Figure

66 Sectignal MIdel df East cladding System
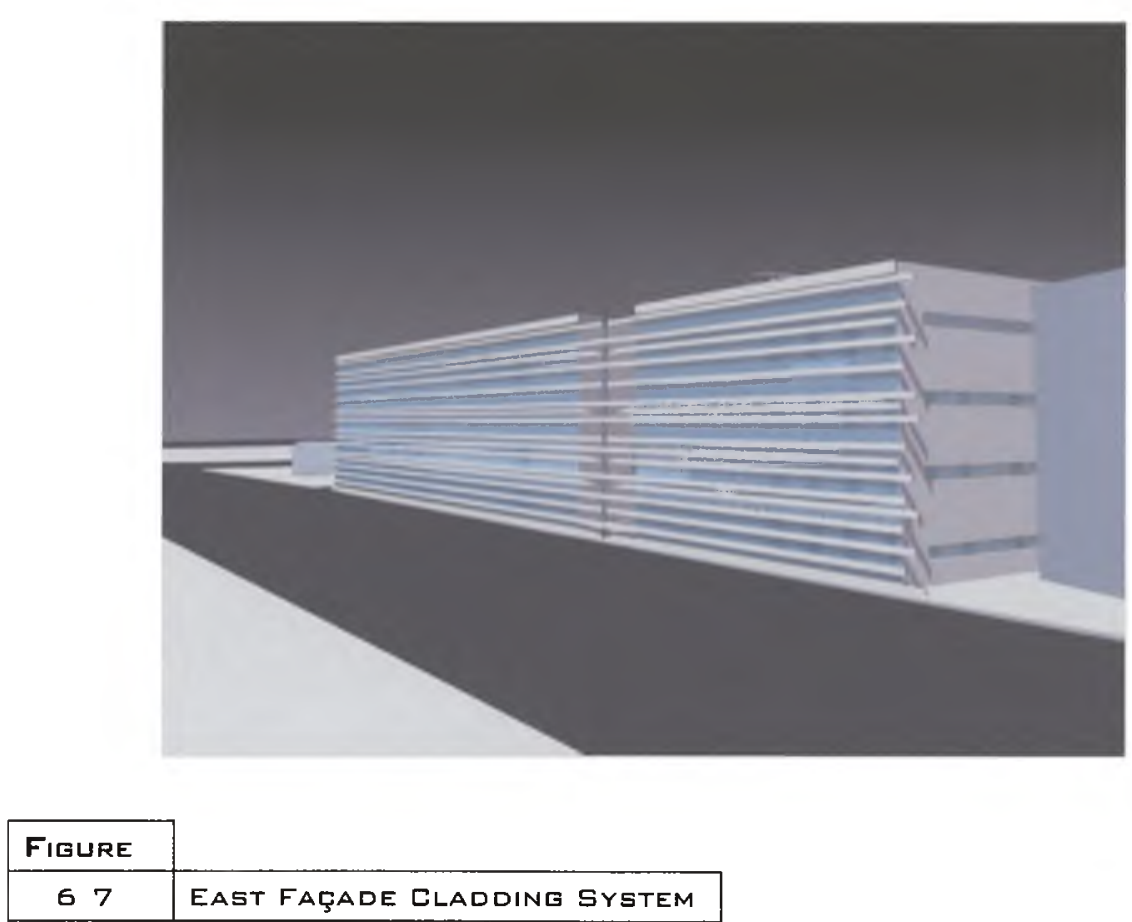

THE BUILDING SYSTEM IS EQUALLY AS INFLUENCED GY MODERN ARCHITECTURE AS IT IS DESIGNED TO CONVEY A SENGE dF PROTECTION (SEe FIGURE 67). THIS DESIGN ACHIEVED THE AESTHETIC OF ABSTRACT RECTILINEAR gONTQURS; AN AEsthetIC THAT GECAME PARTICULARLY PRONOUNCED IN THE 1920 S AND IS STILL WITH US todAY. ALSD, THE BUILdING WAS INTENDED TO SYMEGLIZE THAT REgULARITY AND repetitiveness of modern industrialized materials and construgtion

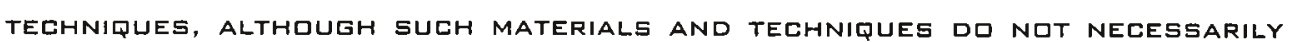
DICTATE RECTILINEAR BUILDINGS.

THE USE OF LIGHTWEIGHT CONCRETE TO BUILD THE BEAMS HELPS CREATE THE appearance df the large monglithic form. The beams do not logk massive. 
THEIR LINEAR SCULPTURAL CHARACTER HAS BEEN FULLY EXPLDITED IN THIS DESIGN. BY THIS IS MEANT THAT THERE IS ND FACING, ND PAINTING, AND ND GVER-EXPOSED DOLRS ALONG THE FRINT FAÇADE GF THE GUILDING. IN TERMS dF LSE AND FUNCTION GF THE gUILDING, THE cONSTRUCTION, MATERIALs, AND VISUAL FORM GF THE BUILDING ARE UNIQUE IN THE ARENA OF SHELTER DESIGNS. THE BUILDING IS NAT INLY AN EXPRESSION OF ITS SURRQUNDINGS GLT ALSO DELIGERATE IN ITS PURPISE TO SERVE THE SHELTER'S NEERs.

THE gUILDING'S EXTRUDED FORM IS EUT FRAM A ERNTINURUS MILD (SEE FIGURE 6G) REPRESENTING THE FLOW IF A CONTINUQUS PROCESS IF THE WOMEN AND CHILDREN

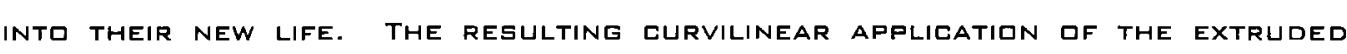
SHAPES CAN GE SEEN IN THE INTERIIR FaRM OF THE BLILDING. THEREFaRE, THE FLOW SATISFIED THE strategic goALs gF gIUNDARIEs, atTACHMENT AND LIGHTING, WHICH WERE COMBINED IN A VARIETY GF WAYS. As A RESULT, THE BUILDING SEEMS TO PLAY CONTRADICTIONS IN ITSELF一 DPEN YET SECURE, SENSITIVE YET POWERFUL.

EVERY GESTURE IN THE DESIGN WAS DESIGNED TO MAINTAIN THE FQCUS ON THE MOST IMPIRTANT ELEMENT IN THE DESIGN: SECURITY. THAT SECLRITY IS PROVIDED GY THE CLISED ENVELGPE CHARACTER GF THE GUILDING AND THE MQNGLITHIC UNITED FAÇADE.

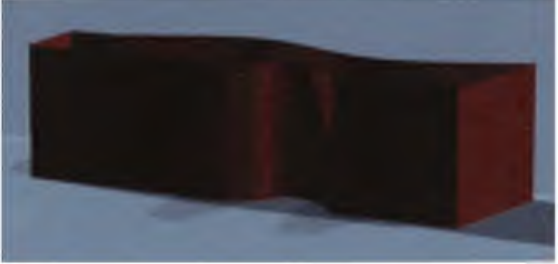

\begin{tabular}{|c|c|}
\hline FIGURE & \\
\hline 68 & STUdY DF INNER FAÇADE \\
\hline
\end{tabular}
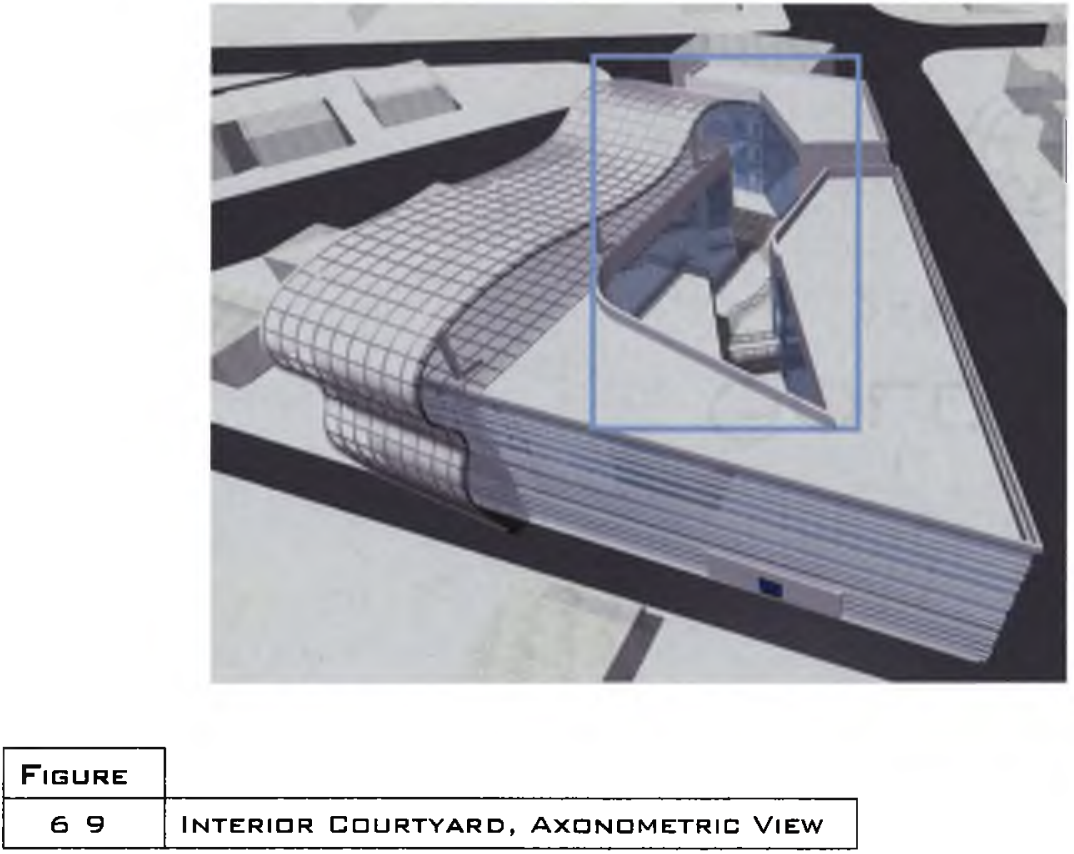

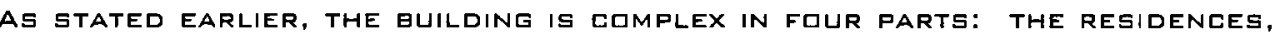
childgare, the administratign, and the gupport gervices. The gtrategy df

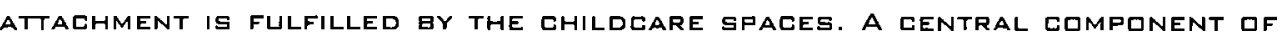

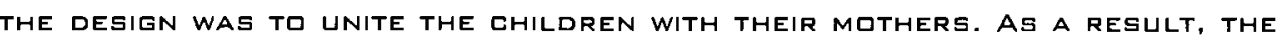
attachment qf the childcare center to the residences makes the gesture of SLlidarity (SEe figure 69).

THE BUILDING BECAME A SERIES OF gUILDINGS SURRAUNDING A GREAT ENCLOSED INTERIOR GLURTYARD THAT hAS NO SINGLE DESIGNATED SPECIFIC FUNCTION, BLT gecomes a safe place far qutside activities and sqCial interaction. As it IS DESCRIBED IN THE DESIGN THE PRINCIPLE QF LIGHTING THE SPACES TO SEAT ARE GETWEEN THE SHADOWS AND LIGHT (SEE FIGURE 7O). 
THE gLASS PANELS SIMULATE AN IPEN ENVIRONMENT fOR THE GLOSED BUILDINGS SURRIUNDING THE EOURTYARD. A SINGLE SCHEME- OFF-WHITE WALLS AND SEMitransparent Light blue glass-Was used for the entire space. The North side,

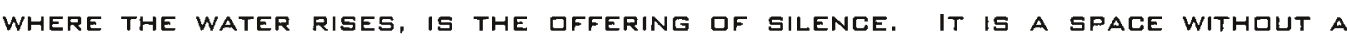
SPECIFIC FUNCTILN; IT GAN BE A SIMPLE SITTING AREA OR A SPACE far EXTERNAL CLUNSELING. THIS INTERIDR CLURTYARD, LANDSCAPE, AND WATER DISSOLVE THE GUTER

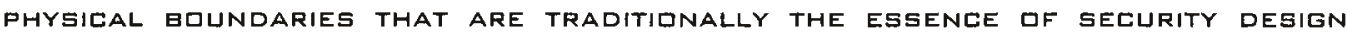
(SEE FIGURE 71).

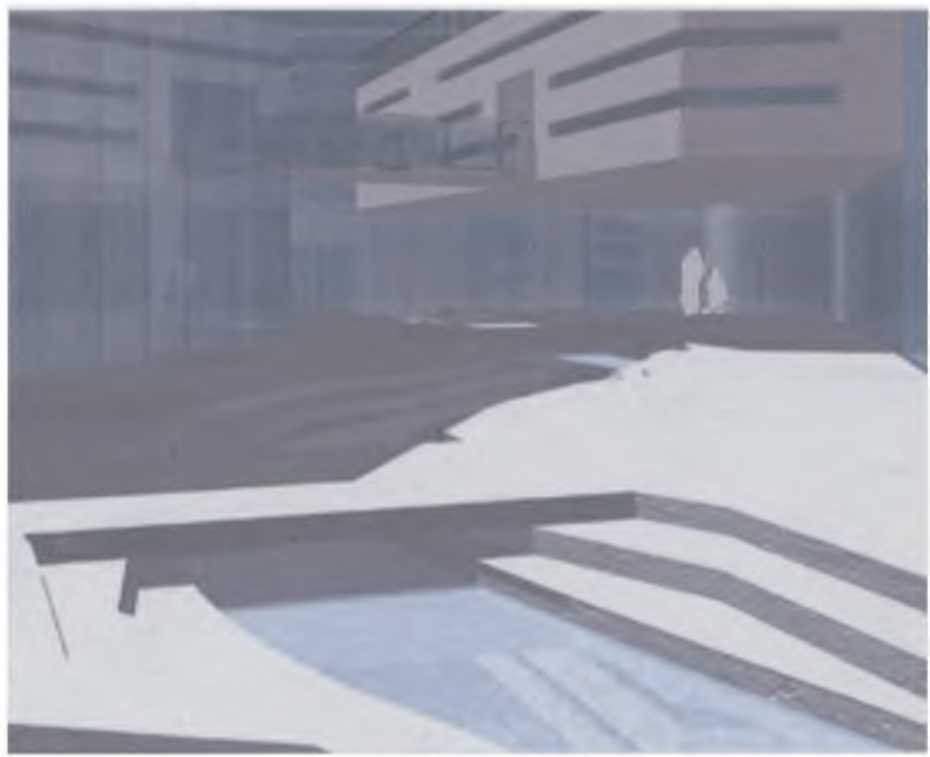

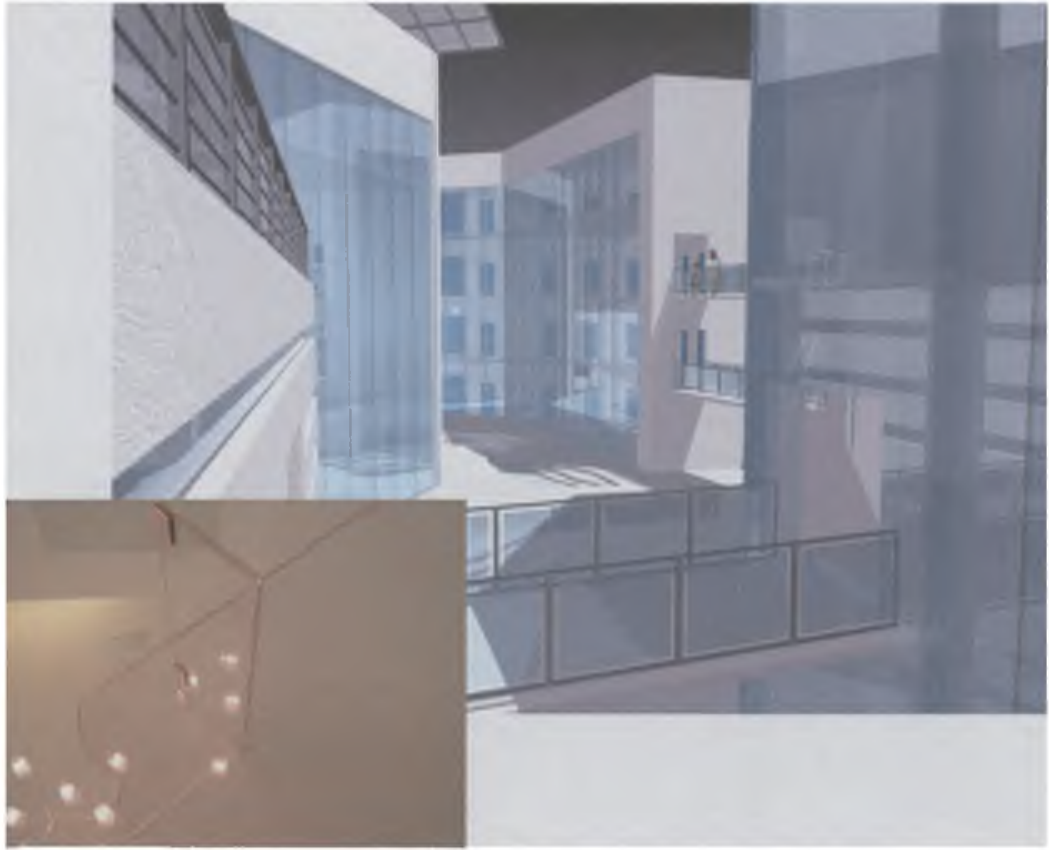

\begin{tabular}{|c|c|}
\hline Figure & \\
\hline 71 & INNER CLADDING SYSTEM MODEL \\
\hline 72 & INNER CLADDING SyStem, CqURTYARd VIEW \\
\hline
\end{tabular}

AT THE TOP OF THE WOMEN'S RESIDENCE GUILDING THERE IS A GARDEN ROAF DESIGN WHICH WAS DESIGNed As A gathering pLACE fuR qUTSIDE RECREATIONAL activities. it can also become a gathering place for qutdogr activities. the thin and almost transparent rogf expresses the rise in the

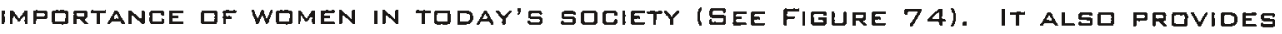
EXTRA SIGNIFICANCE AND PRITECTION TO THE WOMEN'S RESIDENTIAL BUILDING. THE RIDF DESIGN CAN BE DESCRIGED AS A PQETIC EXPRESSION IF THE GRACE AND DELICATENESS IF A WIMAN. 
A RQIF STUDY WAS THE METHOD USED TO DETERMINE THE LIGHTING STRATEGY AS WELL as to formalize the shape of the cangpy rogf. These gtudies simulate of the

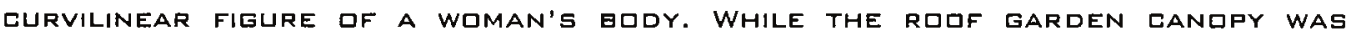
DESIGNED FUNETIONALLY TO PRIVIDE QVERHEAD PROTECTION AND ADEQUATE LIGHT, ITS curved contqurs betray a graceful Elegance.
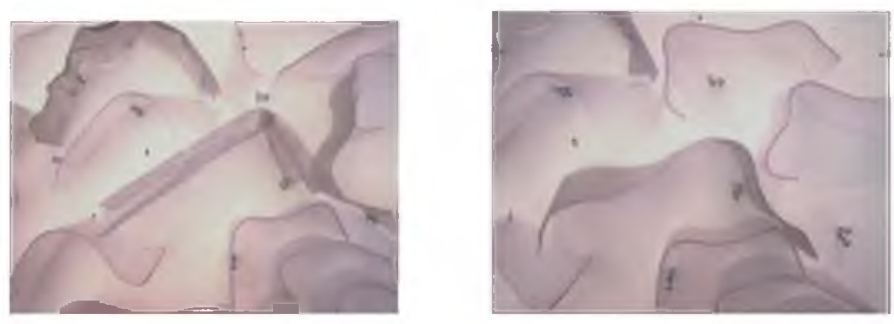

\begin{tabular}{|c|l|}
\hline Figure & \\
\hline 73 & Rogf Study MOdels \\
\hline
\end{tabular}

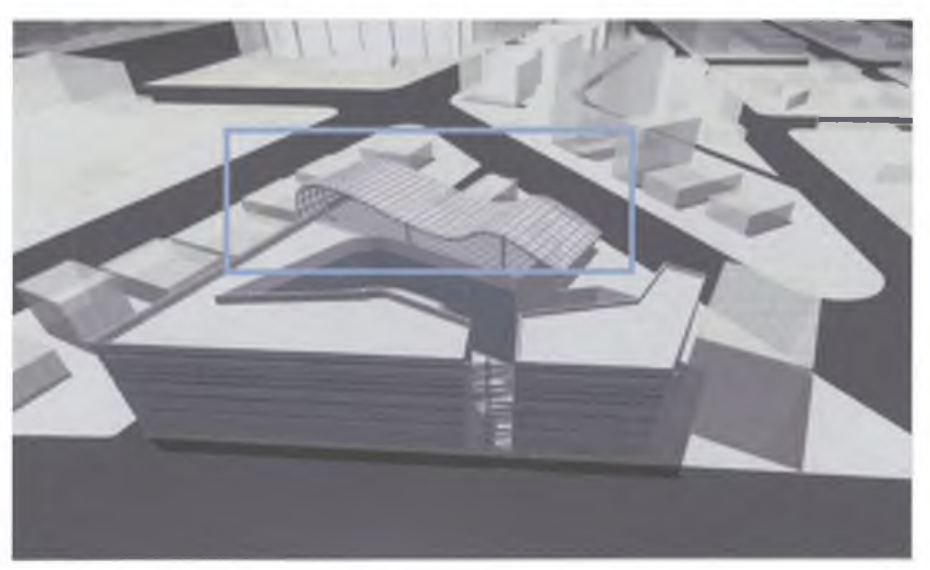

RLIF CANGPY, AXINOMETRIC VIEW
There is hardly a place in this world as peaceful as a garden, thus a rogf garden was added to the program. The garden gffers a gafe place FOR SOLITUDE. WHILE MANY WIMEN WIULD FREQUENT A GEACH GR FOREST FOR TIME TO REFLECT, THE ROOF GARDEN GFFERS SUCH A SPACE WITHIN THE SECURITY OF SHELTER. THEREFIRE, THE RIOF GARDEN WAS DESIGNED TD PRIVIDE A REFUGE

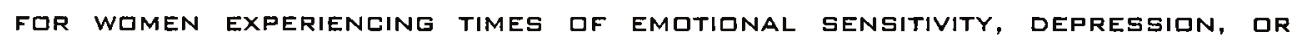
ANXIETY DISORDERS. ALSD, THE SHELTER COULD EVEN PROVIDE RESIDENTS THEIR OWN SPACES TD DO THEIR OWN GARDENING.
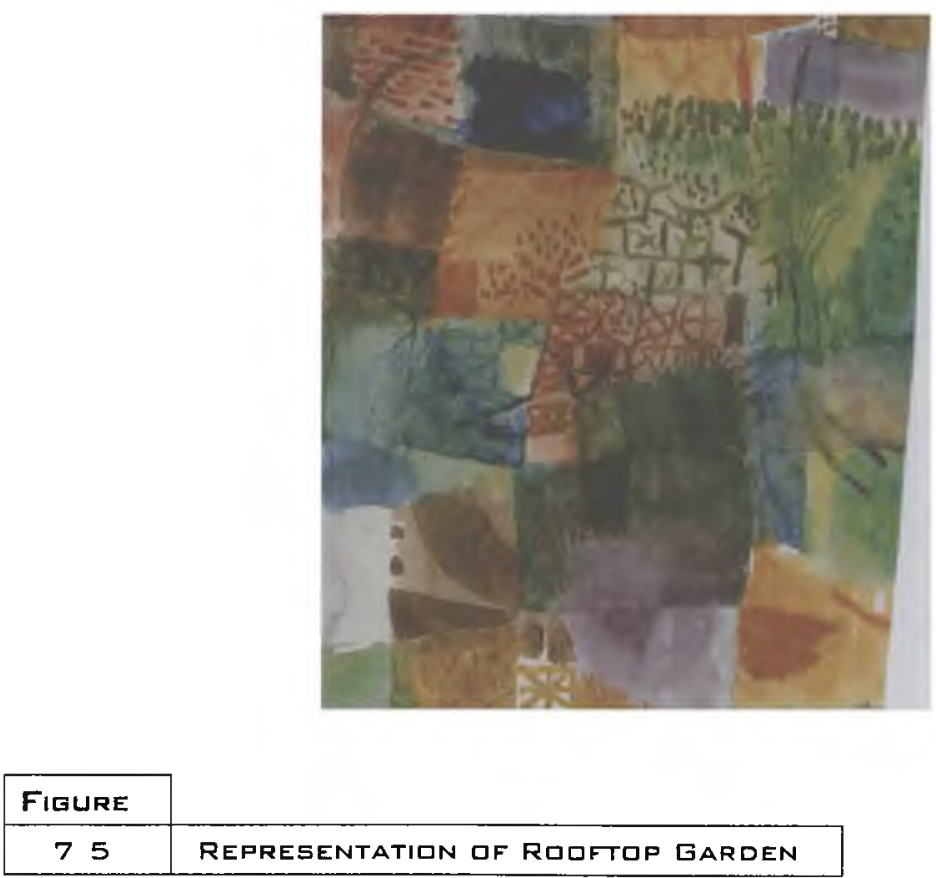

THE ELEMENT IF THE BUILDING ENTRANEES WAS A CAREFULLY ANALYZED VARIABLE. For security purptses entrances are designed fram two different Pergpectives: pedestrian actess and Vehigular agcess. Pedestrian access 
IS GPECIFICALLY GEARED TOWARD VISITIRE WHI GAN PARK IN THE STREET AND WALK TD

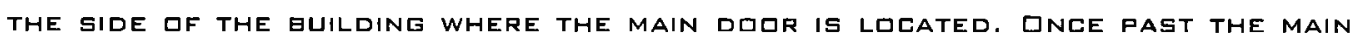
DORR, THE SECURITY GUARD INTERVIEWS THE VISITOR. AT THIS POINT, ANOTHER WALL PREVENTS THE VISITOR FROM ENTERING THE GUILDING. THE VISITOR IS THEN INTERVIEWED Again gefore gaining access to the interiar of the guilding. The Vehicular ENTRANCE IS DESIGNED GNLY FGR RESIDENTS' VEHICLES. BECAUSE THIS IS THE MOST dangergus and vulneragle area df the complex, the technology and MATERIALS CHOSEN FUR THE PARKING AREA ARE REINFORCED GINCRETE, BULLET-PRDOF gLASs, AND A SECURITY SYSTEM WITH CLOSED-CIRCUIT CAMERAS AND ALARMS.

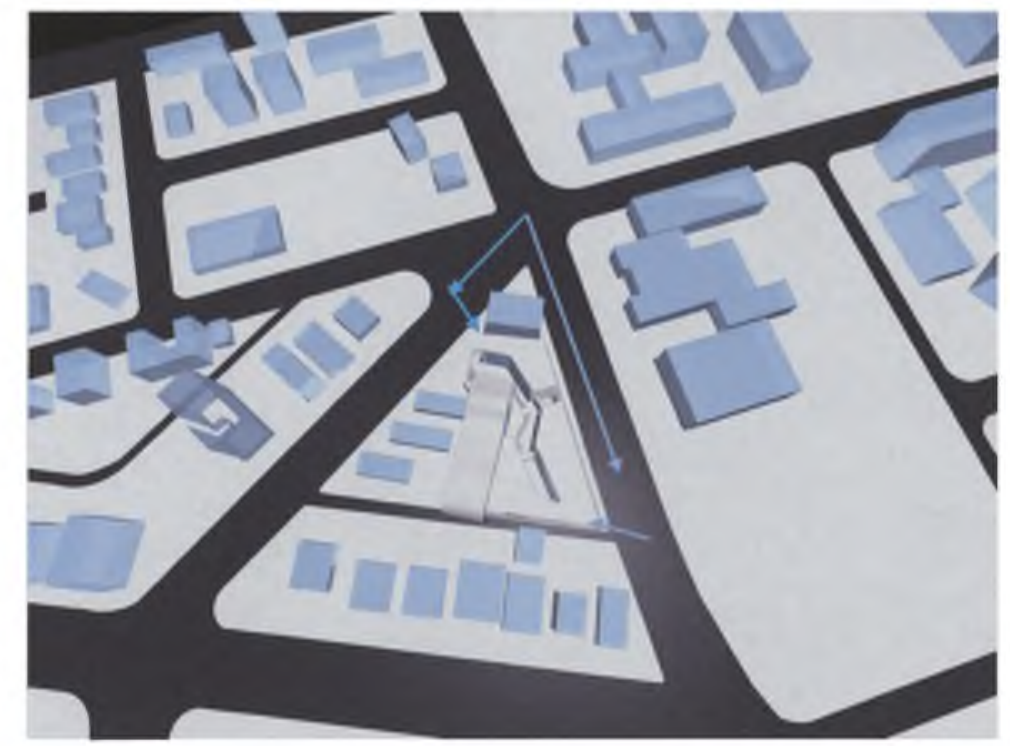

FIGURE

76 ENTRANCE LOCATION OF BUILDING

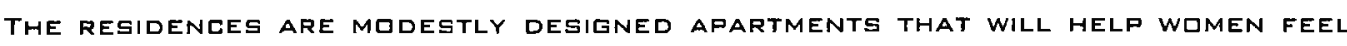
Like they are at hIME. Eagh unit contains a living rogm, a dining ragm, a

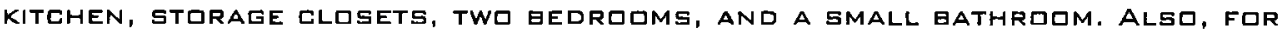
EMERGENCY PURPQGES, TEMPGRARY ROIMS ARE LOCATED IN THE ADMINISTRATION BUILDING. WUMEN AND EHILDREN LAN STAY IN THESE UNITS UNTIL A REGULAR RESIDENTIAL UNIT IS AVAILAgLE.

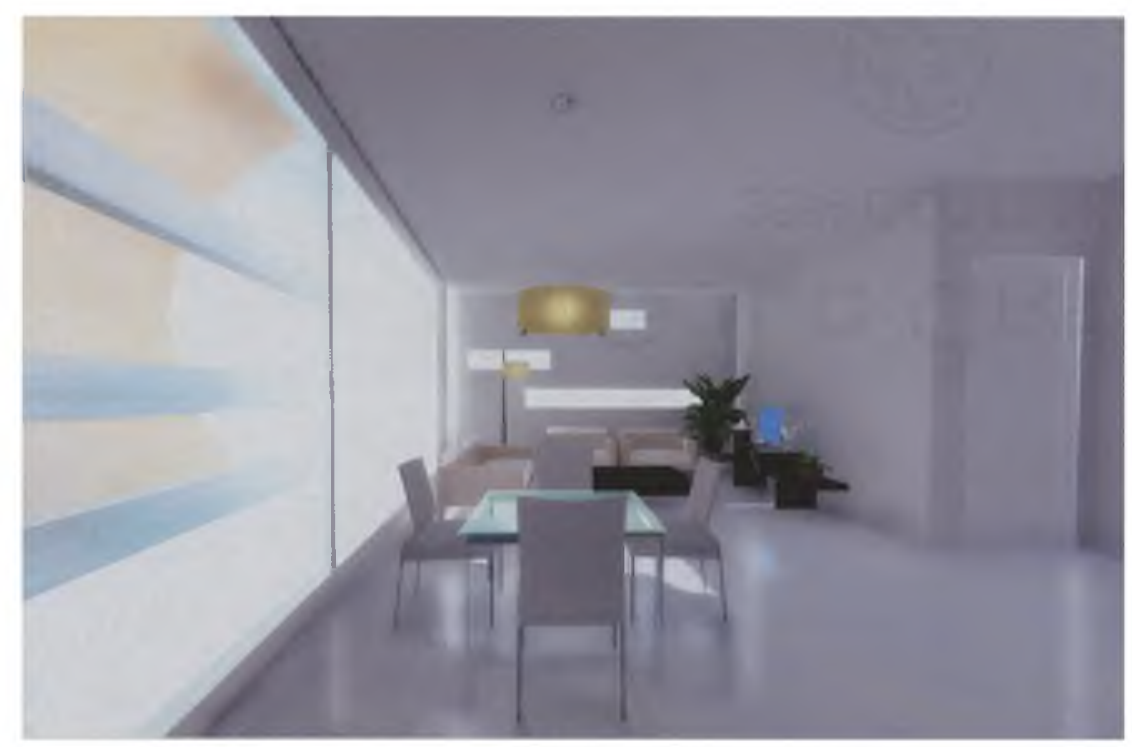

FIGURE

77 TYPICAL RESIDENTIAL INTERIOR UNIT

more than one family may ge visiting at the same time. Therefore, the

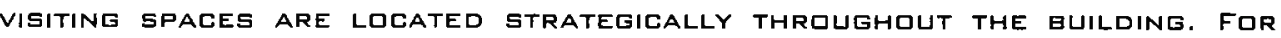
MATTERS GF PRDTECTION THESE ARE NOT ENCLOSED ROIMS, HOWEVER PRIVACY IS TAKEN IN CONSIDERATION (SEe SITTING AREAS IN FLogR PLANS, PAgE 7 ). 
THE coUnseling gfFices are designed separately-mathers an the segand

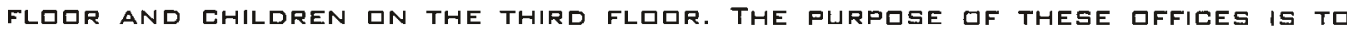
PRIVIDE A LLEAR AND COMFIRTAGLE SPAEE FOR SUPPORT CQUNSELING.

THE CRISIS INTERVENTION GFFICES WILL BE USED BY THE PSYCHOLOGIST AND OTHER staff to NGRMalize situations as the neEd arises. DURING grisis, the shelter MUST IFFER EMITIONAL SUPPIRT AND COUNSELING FIR BOTH MITHER AND CHILD (HARns 1998). The affices are designed to provide needed isglatidn. There

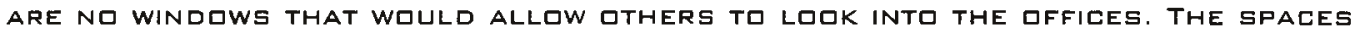
are comfortagly large and Lighting enters through the elevated Windows QVER THE DORRS.

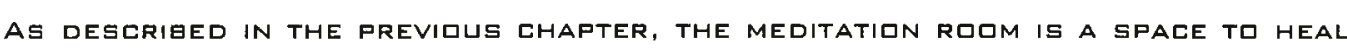

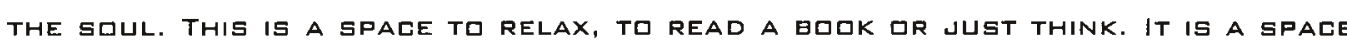

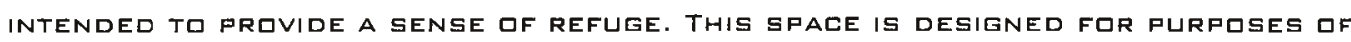
meditation and transfurmatign, as a place to generate pusitive thinking, a

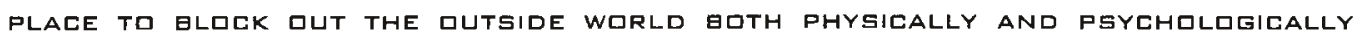
(SEE FIGURE 78).

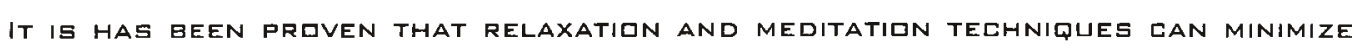
SYMPTIMS RELATED TO STREss, SULH AS TENSION, FATIGUE, ANXIETy, DEPRESSION, INABILITY TO LONCENTRATE, AND IRRITAGILITY. RELAXATION AND MEDITATION can

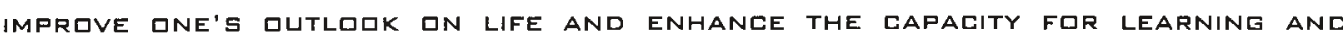

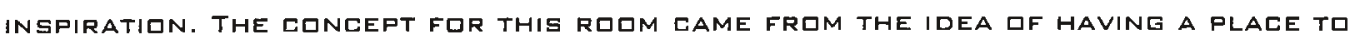
REHAGILITATE AND PROVIDE SPACES TO ENHANCE SELF-ESTEEM AND SELF-CONFIDENCE.

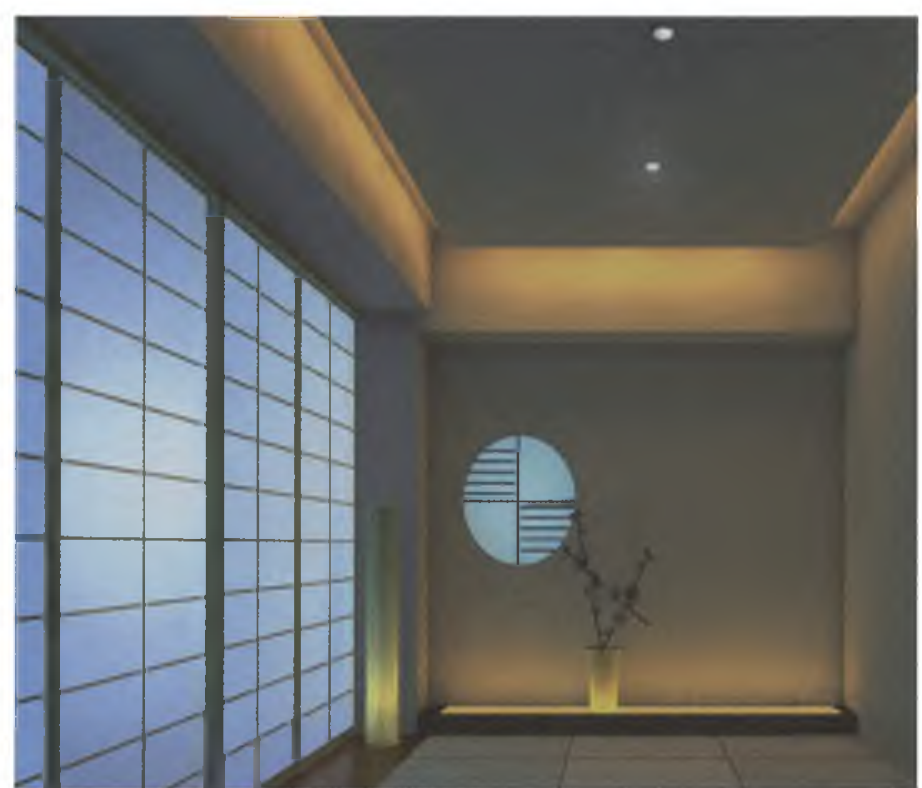

FIGURE

7 a MEditation spaces, interigr View 


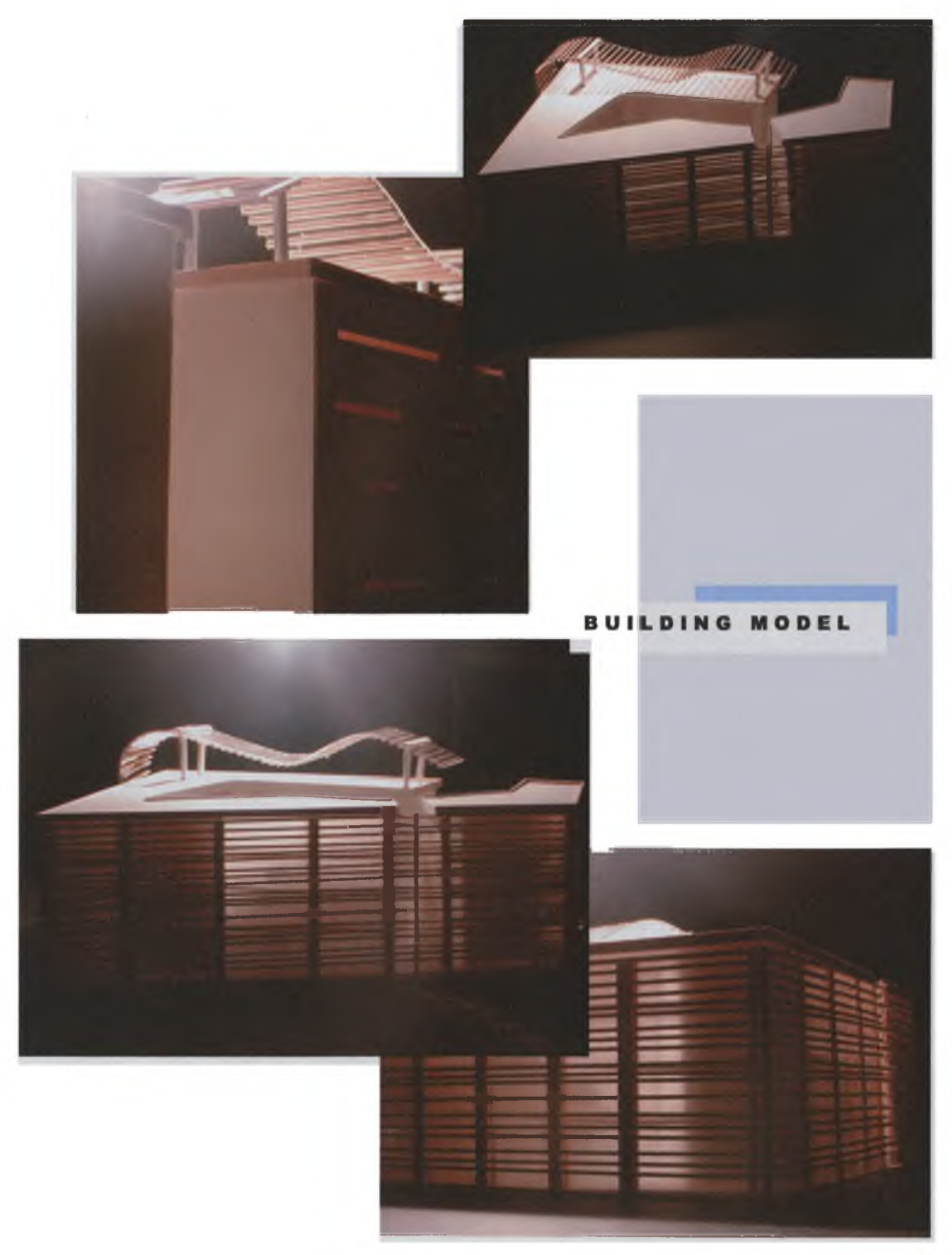




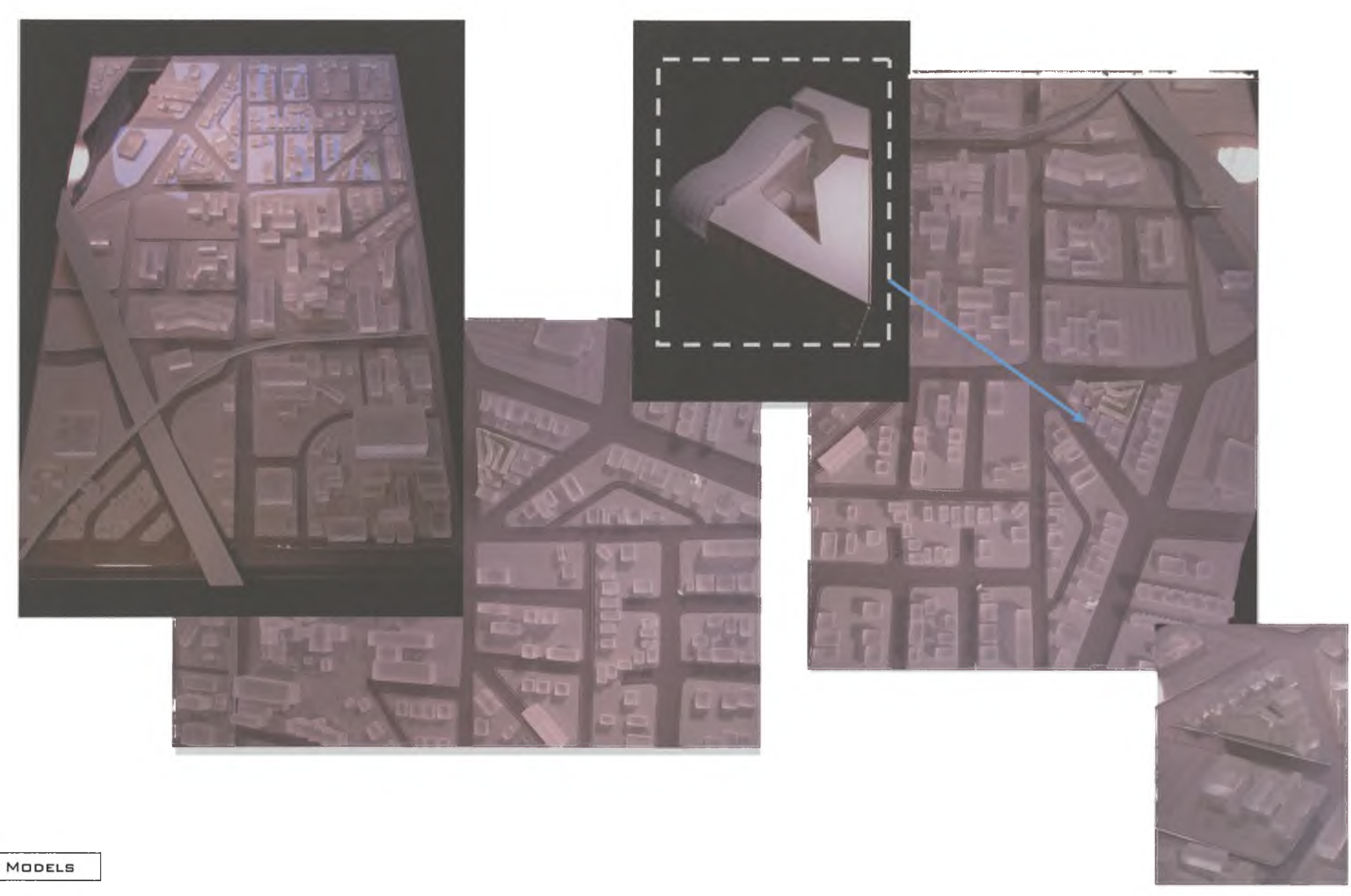




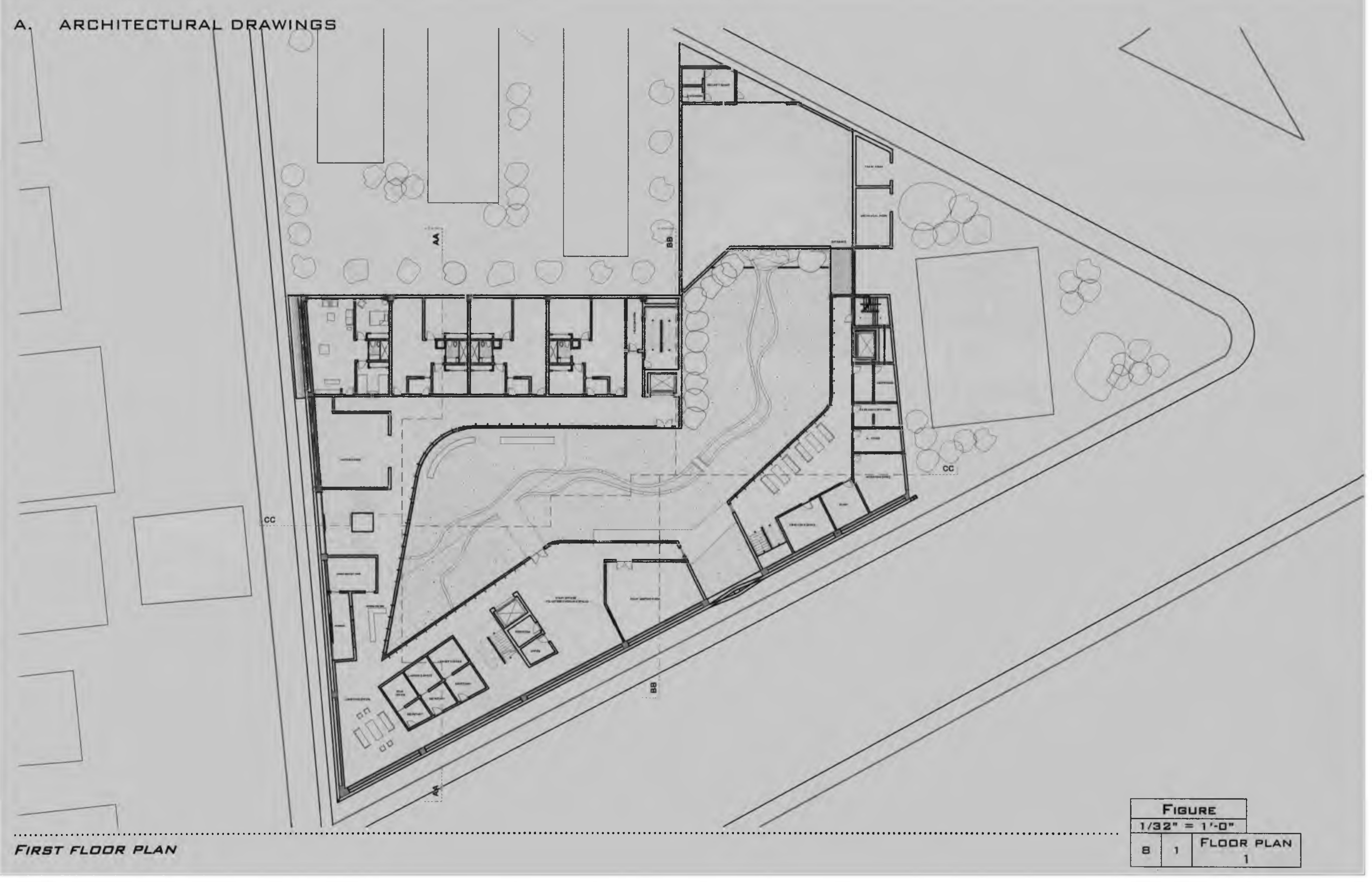




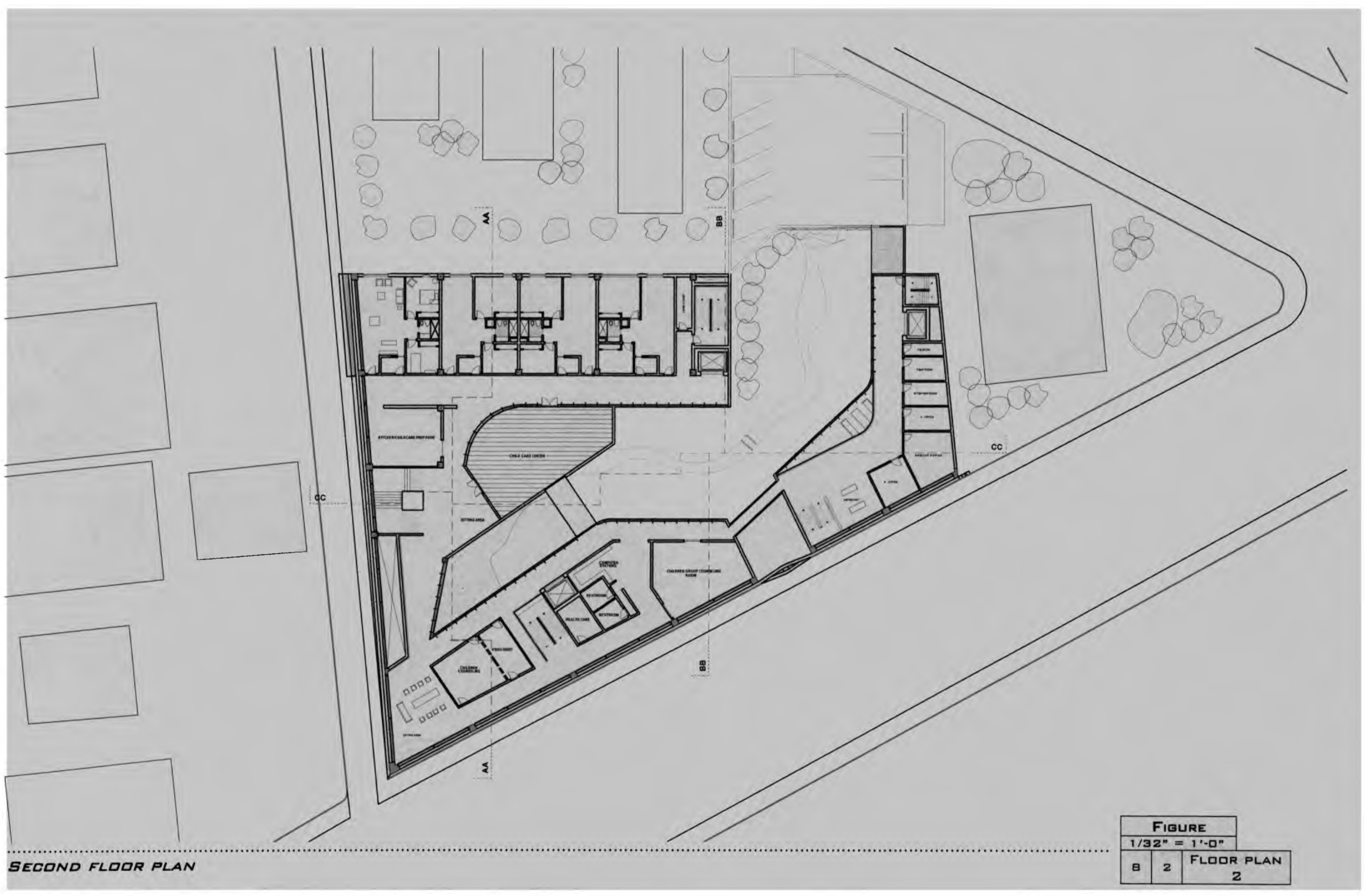




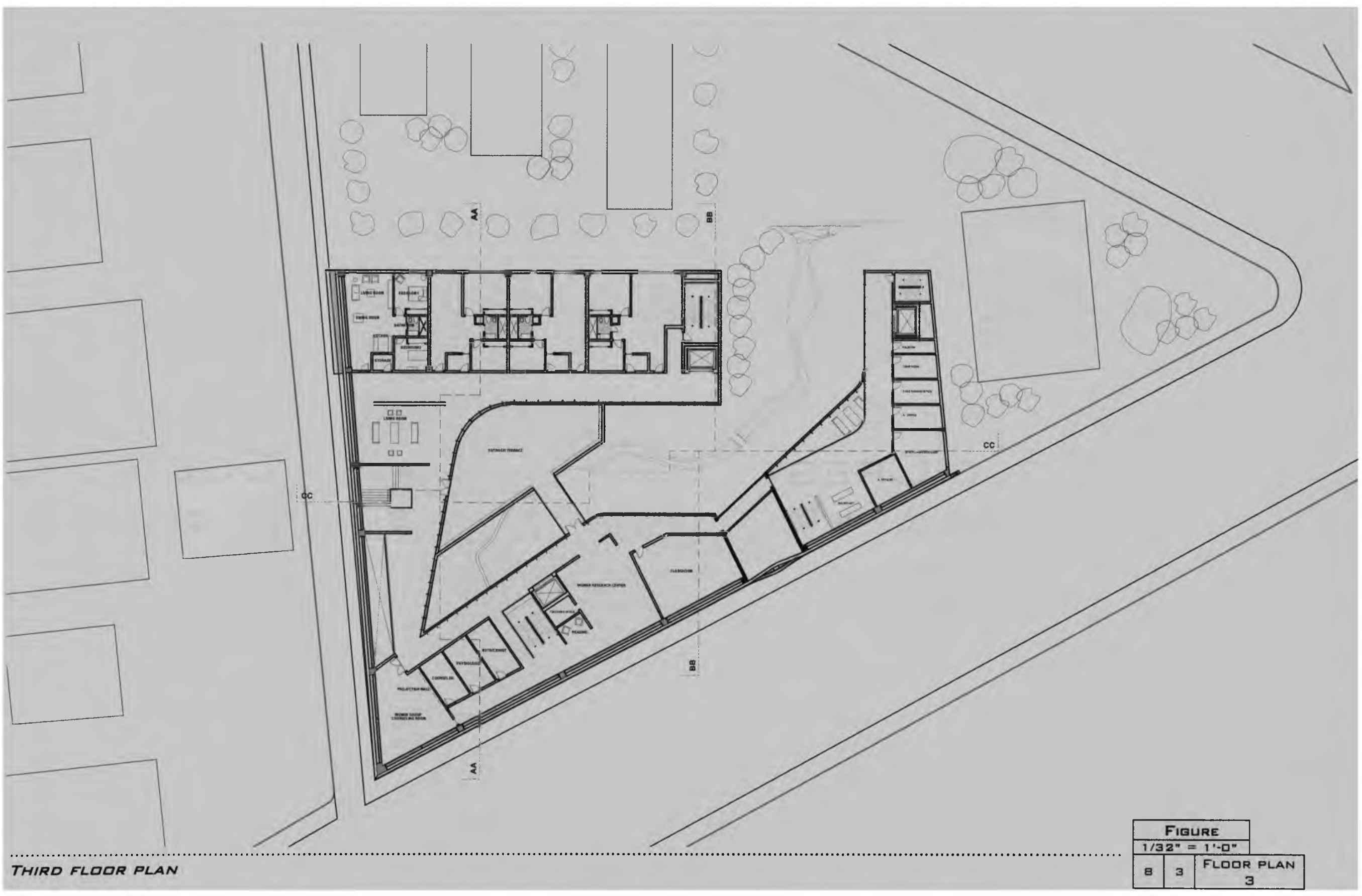




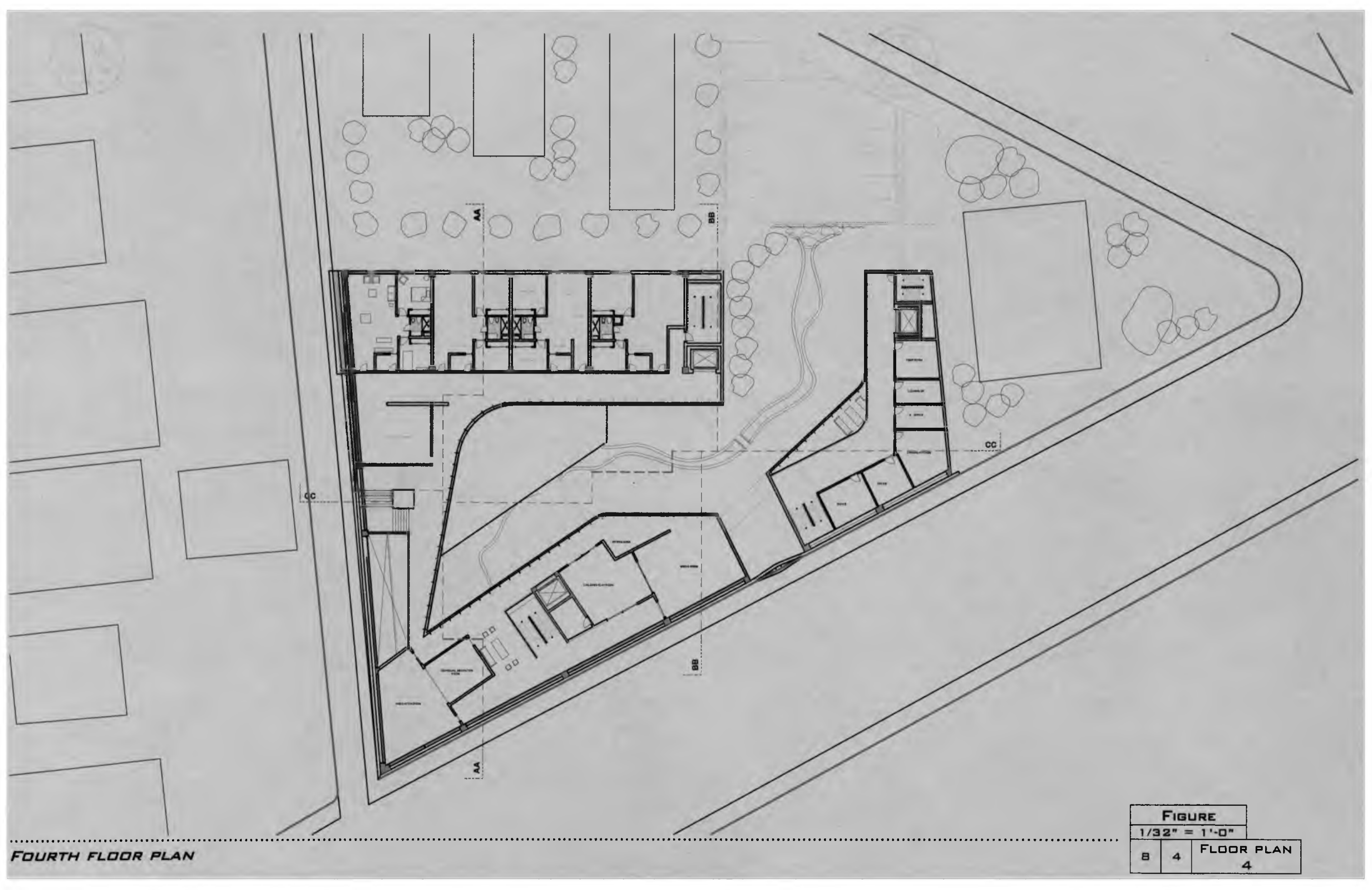




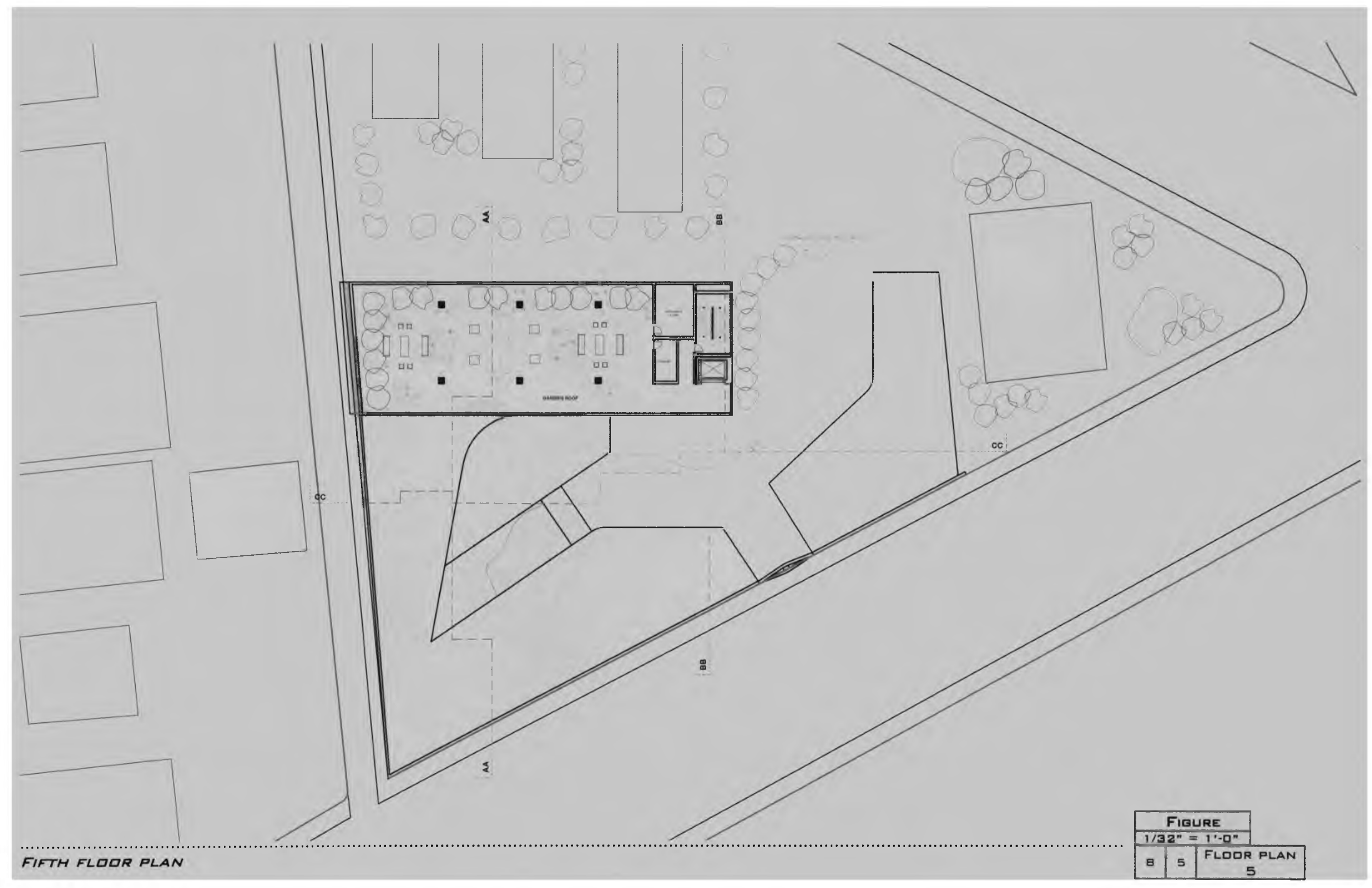




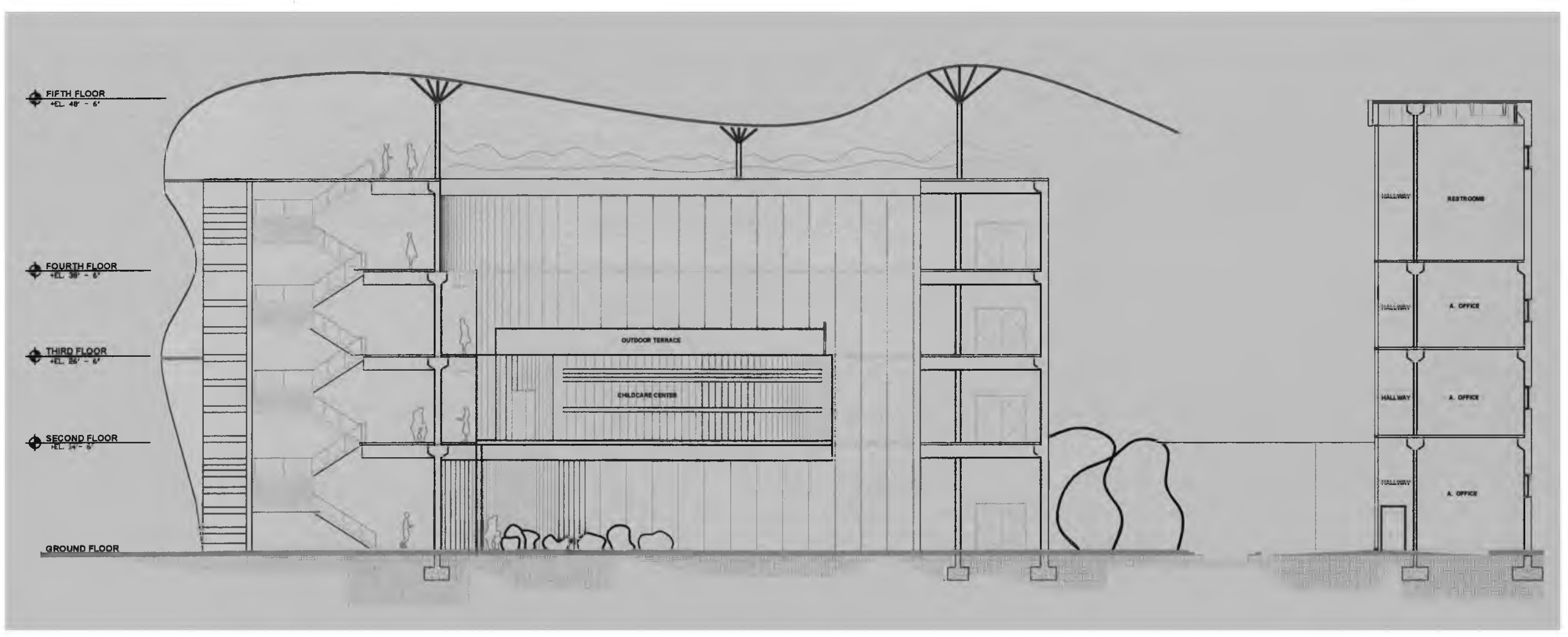




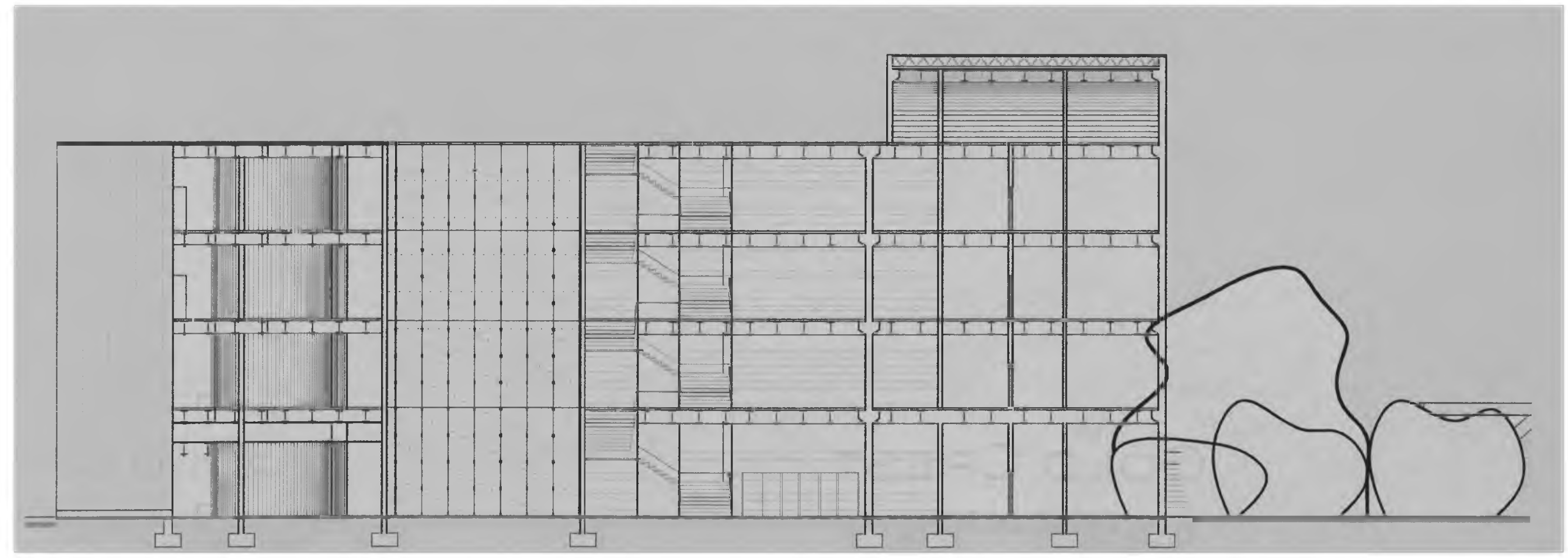




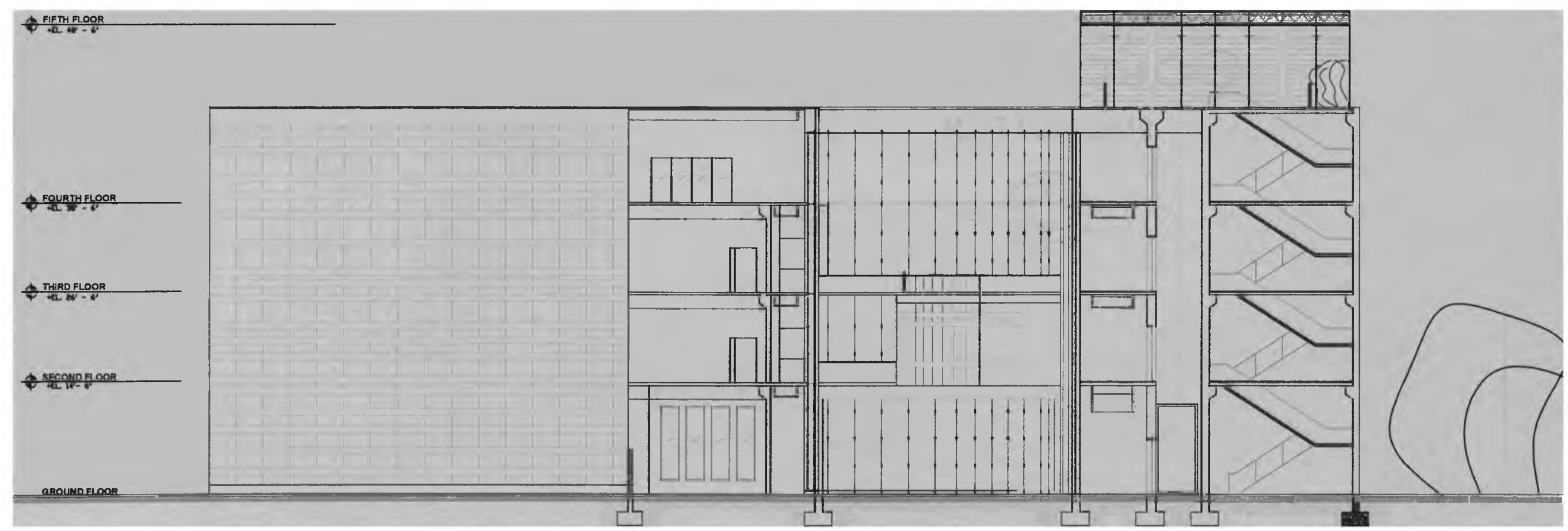




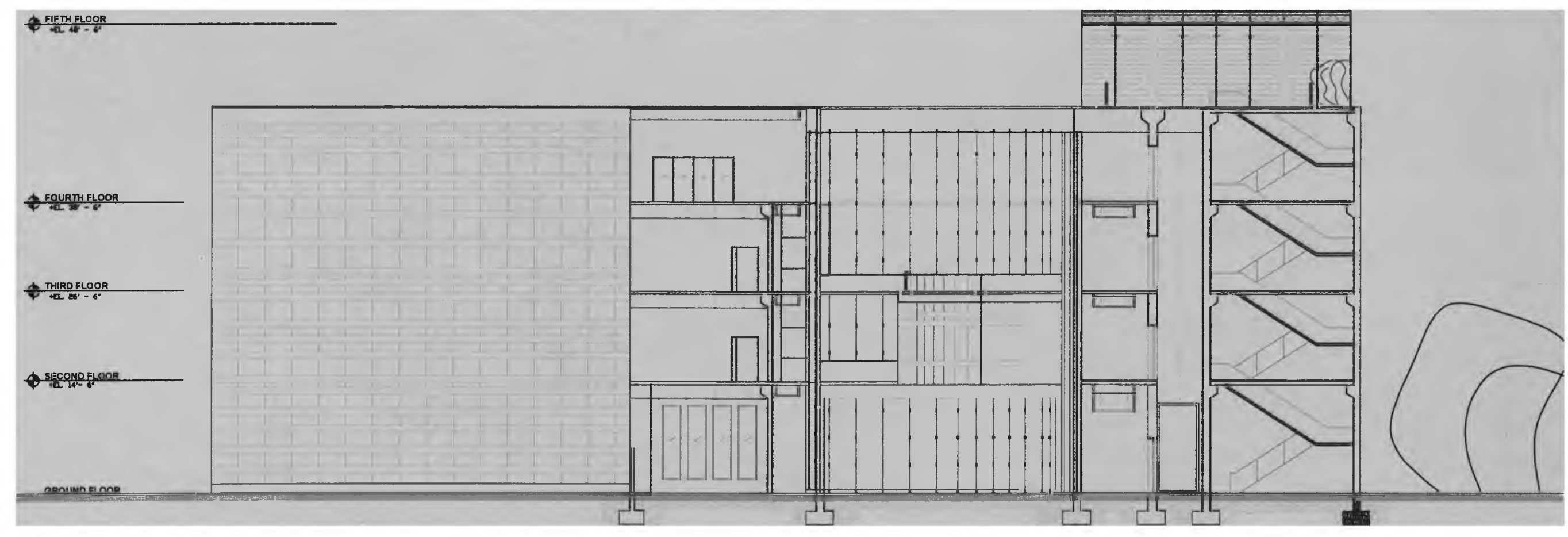




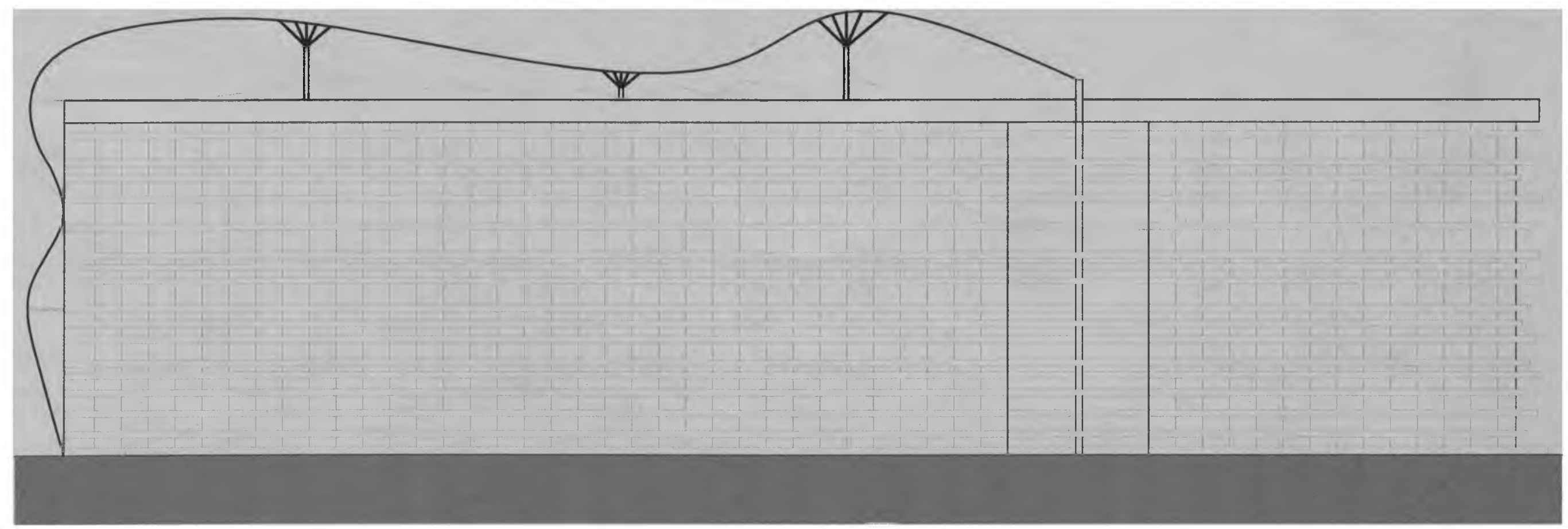

EAST ELEVATION

\begin{tabular}{|c|c|c|}
\hline \multirow{2}{*}{\multicolumn{3}{|c|}{$\frac{\text { FIIGURE }}{3 / \mathbf{3}^{n}=11^{\prime} 0^{n}}$}} \\
\hline & & \\
\hline घ & 9 & $\begin{array}{c}\text { EAST } \\
\text { ELEVATION }\end{array}$ \\
\hline
\end{tabular}




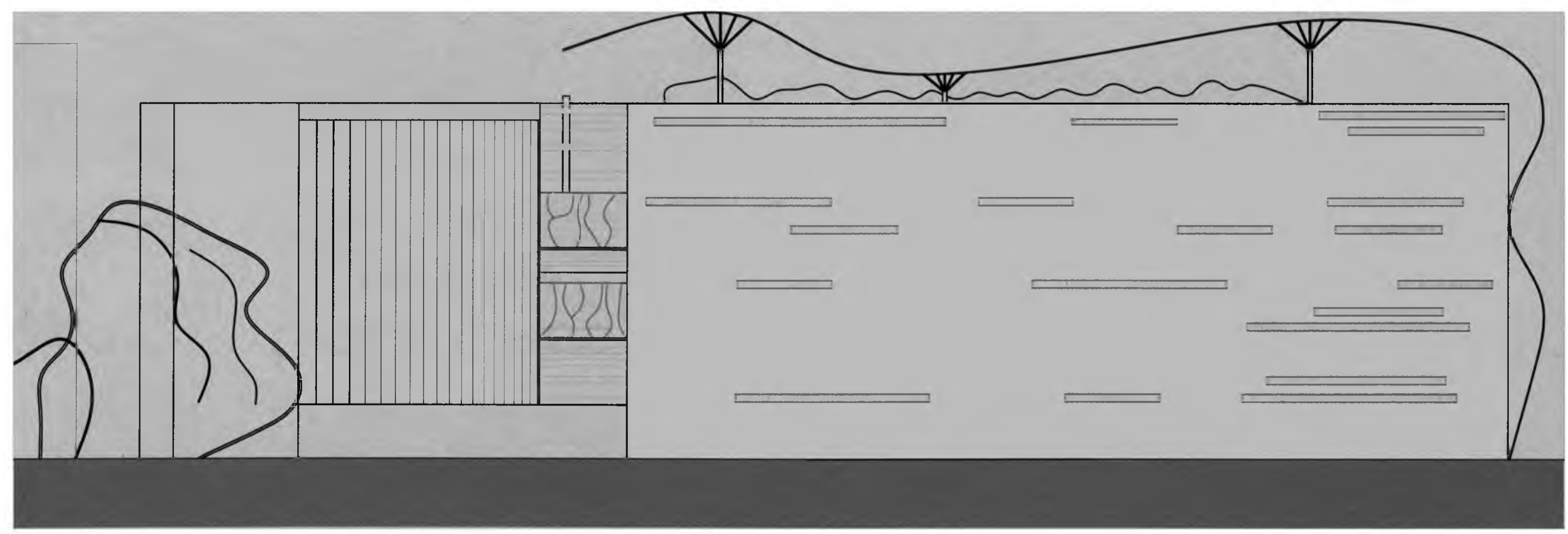




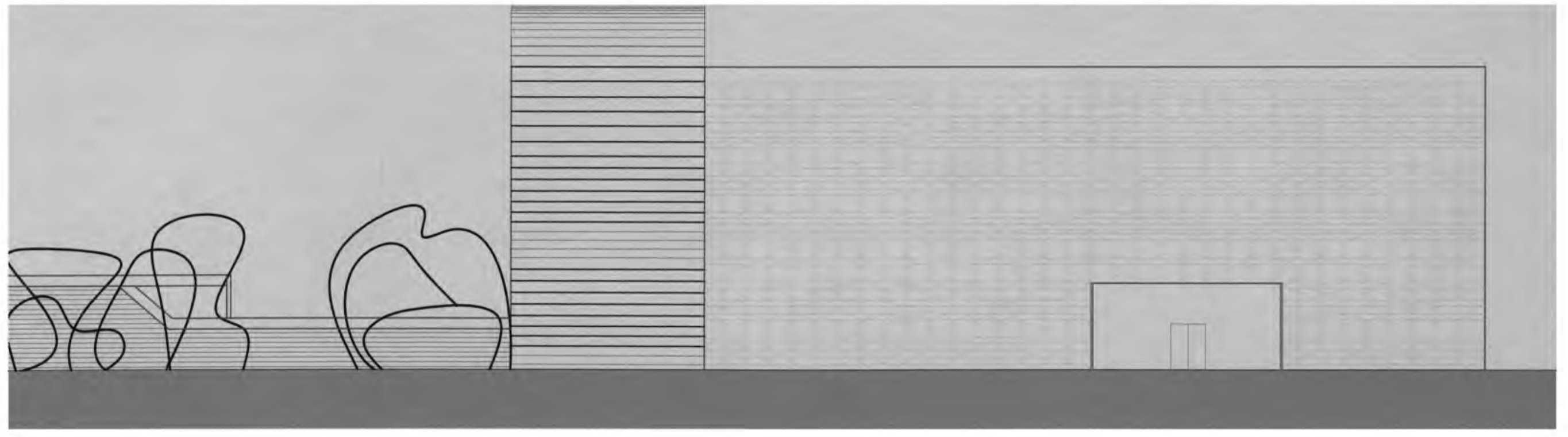




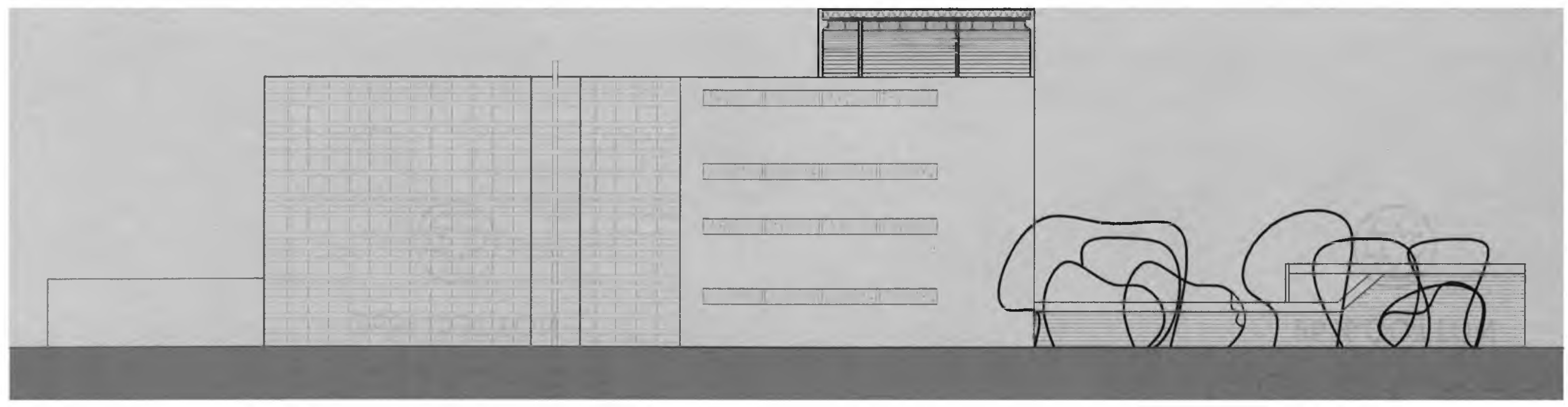

Figure 


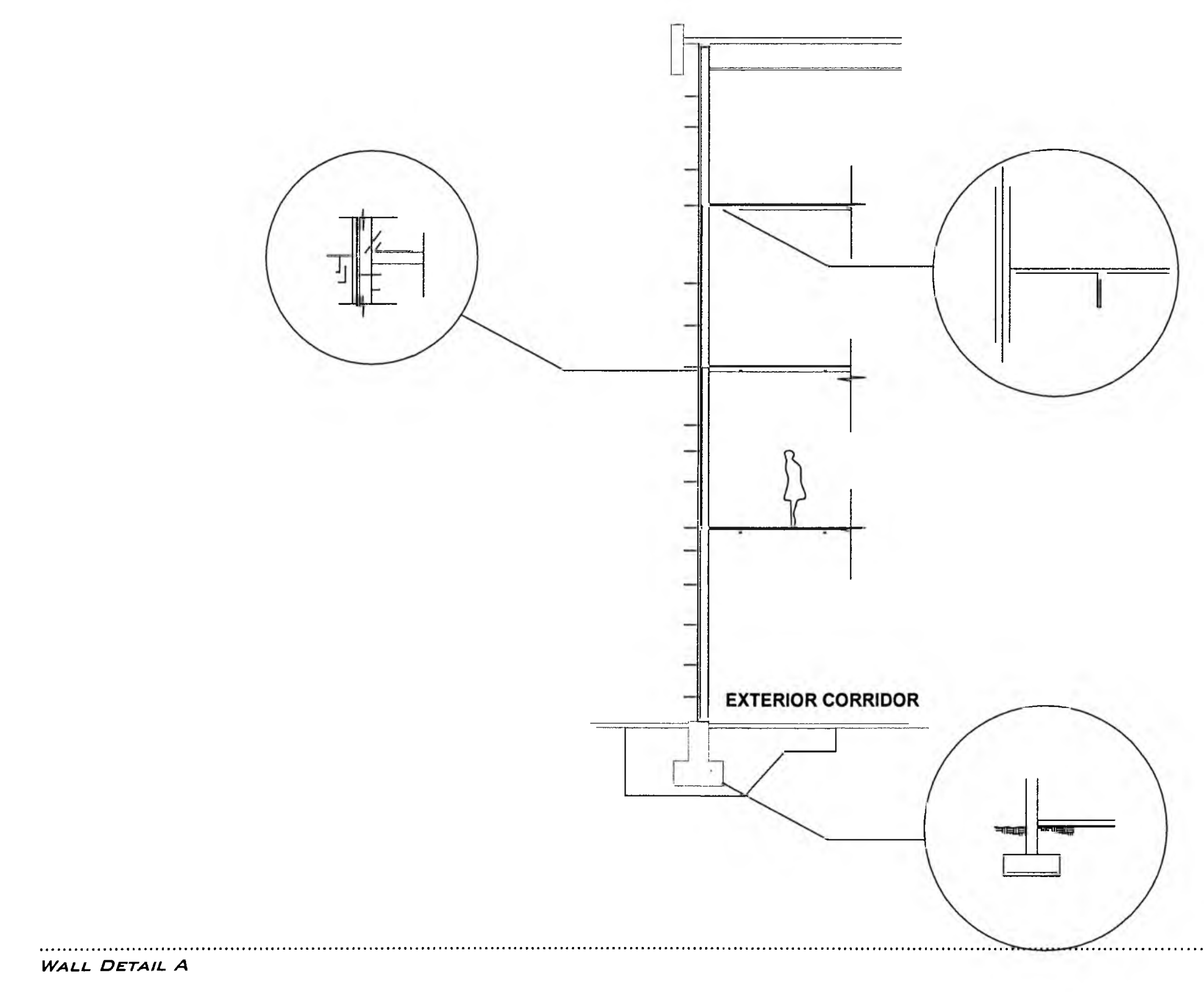




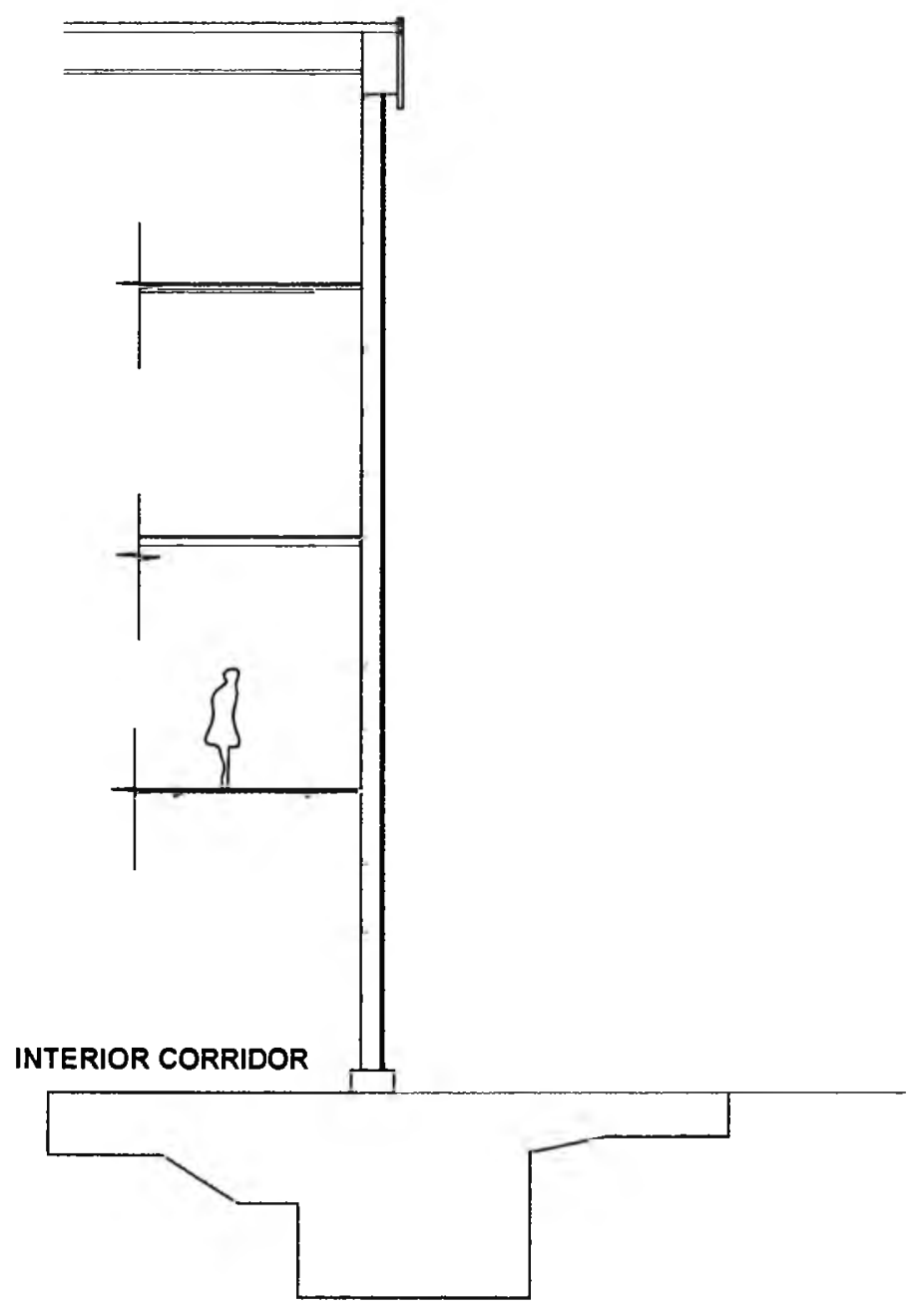

WALL DETAIL B

\begin{tabular}{|c|c|c|}
\hline \multicolumn{3}{|c|}{ FIGURE } \\
\hline $1 / 32^{n}=1 \cdot 0^{n}$ \\
\hline 9 & 3 & $\begin{array}{c}\text { WALL DETAIL } \\
\text { 日 }\end{array}$ \\
\hline
\end{tabular}




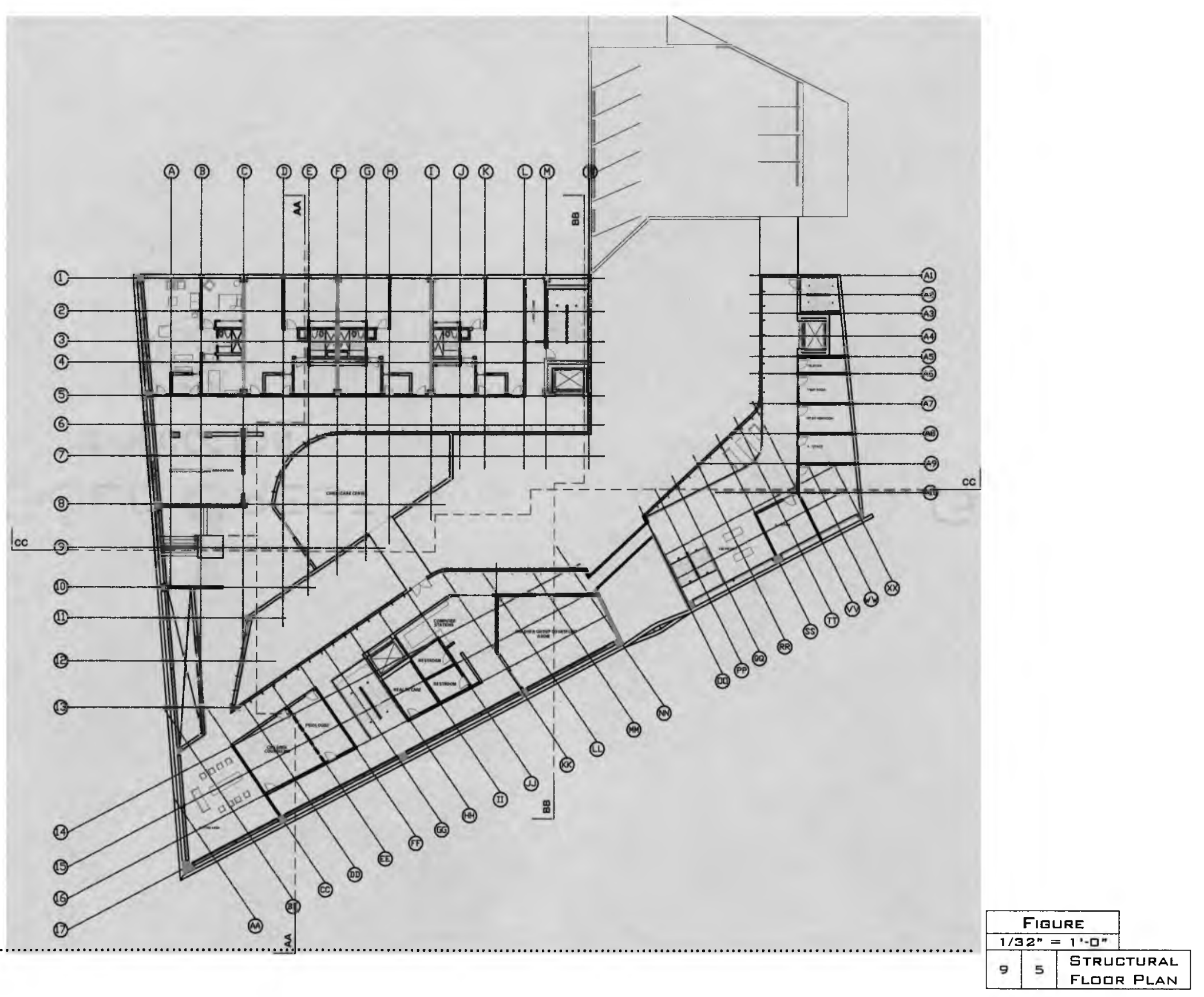


CHAPTER IX

CONCLUSION

THE RESULTING ASYLUM PROJECT ESTABLISHES ARCHITECTURAL PATTERNS AND DESIGN STRATEGIES IN RELATION TO WOMEN WITH GHILDREN IN NEED GF A HOME.

THIS ARCHITECTURAL STUDY SPANS A BRDAD hISTORICAL BASE IN THE gUEJECT OF WIMEN IN NEED OF SHELTER. IT IS NOT ONLY INTENDED TO BE SIMPLY A FUNCTIONAL STUDY TO HELP WOMEN IN NEED BUT ALSO TO BRING TO THE FOREFRONT A REALITY OF DOMESTIC VIOLENCE THAT STILL EXISTS IN QUR SOEIETY, A REALITY THAT TODAY PEOPLE ARE TAKING AETION TO IMPROVE. THEREFGRE, ARCHITECTURAL DESIGN IS IN ESSENCE A propusal for creating meaningful ghange in the miami community. During the RESEARCH I GAINED A FULLER UNDERSTANDING OF WIMEN'S GRGANIZATIONS NOT ONLY in spiritual disciplines, BUt ALSO IN THE LARGER SOCIAL, ECONGMIC, AND GULTURAL CONTEXTS. AS A RESULT, THE SHELTER DESIGN IS NOT ONLY A MANIFESTATION IF FIRM, FUNCTION, PRITECTION, AND DEFENSE BUT ALSD A REVELATION OF THE SOCIOECONGMIC

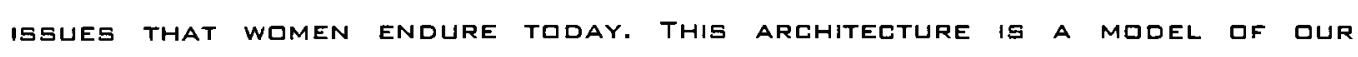

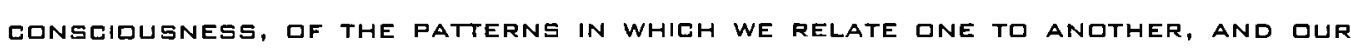
DEsire to ENSURE the WELL-GEING dF others.

in this thegis, the functionalism of mLdern arghitegture was promoted

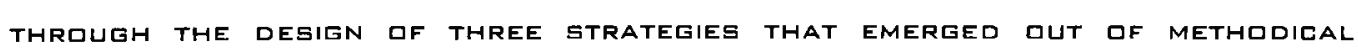
research. These strategies fullowed the program, the spatial requirements, THE FUNCTIONS DF THE GUILDING. AND THE RELATIONSHIP gETWEen the LANGUAGE of space and ugers. The considerations of the program estaglished the FRAMEWIRK FOR THE STRATEGIES, WHICH IN TURN INFLUENCED THE AESTHETICS OF THE BUILDING. IN EARLIER TIMES, DESIGNS FOR THIS TYPE OF GUILDING WERE LIKELY

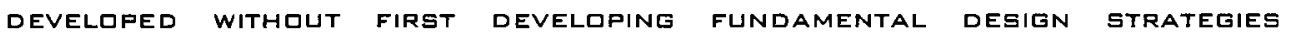
Essential to this architectural typolqgy. THE design strategies were

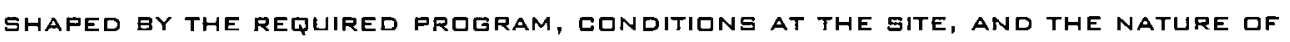
THE GUILDING FUNCTIONS. THE THREE DESIGN STRATEGIES-GOUNDARIES, LIGHTING, AND ATTACHMENT-WERE LINKED GY A COMMON FOCUS ON THE PRINCIPAL FUNCTION OF PROVIDING PRQTECTION IN THE FINAL DESIGN.

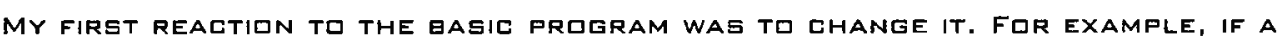

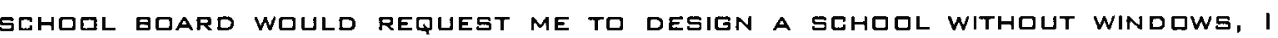
WQULd resist the design. Light is essential to life, to learning, and so to the optimal design of a schogl. THerefore, I started the design frocess a Variety of design strategies that eVentually became a collection of SChematic design models that underwent eValuatian. My thesis committee WORKED VERY HELPFUL WITH ME IN REWORKING THE CONCEPTS THAT AROSE FROM the strategies developed. A powerful lesson has geen that design

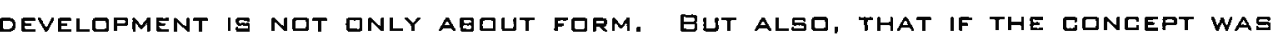
NOT DEVELOPED GEGINNING FROM THE VERY gASICS IT WAS NOT GOING TO WORK AS A THESIS PROJECT. THAT IS WHY THE DEVELOPMENTS FROM DIFFERENT STUDIES WERE NECESSARY AND HAPPENED UNTIL THE DESIGN WAS THE MOST MEANINGFUL ane. Lltimately, I learned not only that farm is impersonal, that it geLONGS TO THE BUILDING BUt, ALSO THAT DESIGN BELONGS TD PEDPLE AND COMMUNITIES.

today, society tends to regard public institutiong negatively. We think THAT LAREE, GLREAUERATIC, UNREgPINGIVE GRGANIZATIONS ARE MURE CONCERNED With their own growth than addressing human NeEds. However, in the 


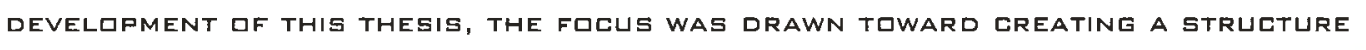
that Wquld encqurage regpangiveness to human NeEds and desires, such as THE DESIRE FOR RESPECT, AND MUTUAL ASSISTANCE.

in ADDitign, the final arghitectural design arage from the belief that the

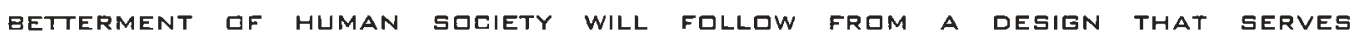
IDENTIFIABLE PHYSICAL hUMAN NEEDS. IT IS THE EXPRESSION OF THE STRONG belief

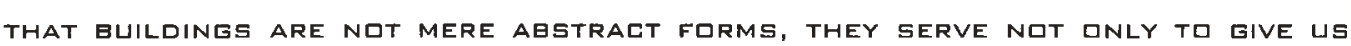
shelter but are plages in Which We graw and learn eVery day. fur these REASONS THIS GUILDING GIULD PRQVIDE MEANINGFUL SUESTANGE TO QUR LOMMUNITIES

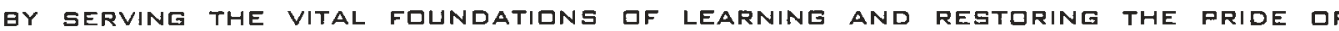
WIMEN.

in canclusign, this arghitectural design is aN EXPREssign NDT ONLY DF REQUIREMENTS gUT ALSO FULFILLS THREE BASIC AND POWERFUL HUMAN NEEDS: THE NEEd FIR SELF-PROTECTION, THE NEED FIR SELF-EsteEM AND THE NEED TO DISCGVER HAPPINESS.

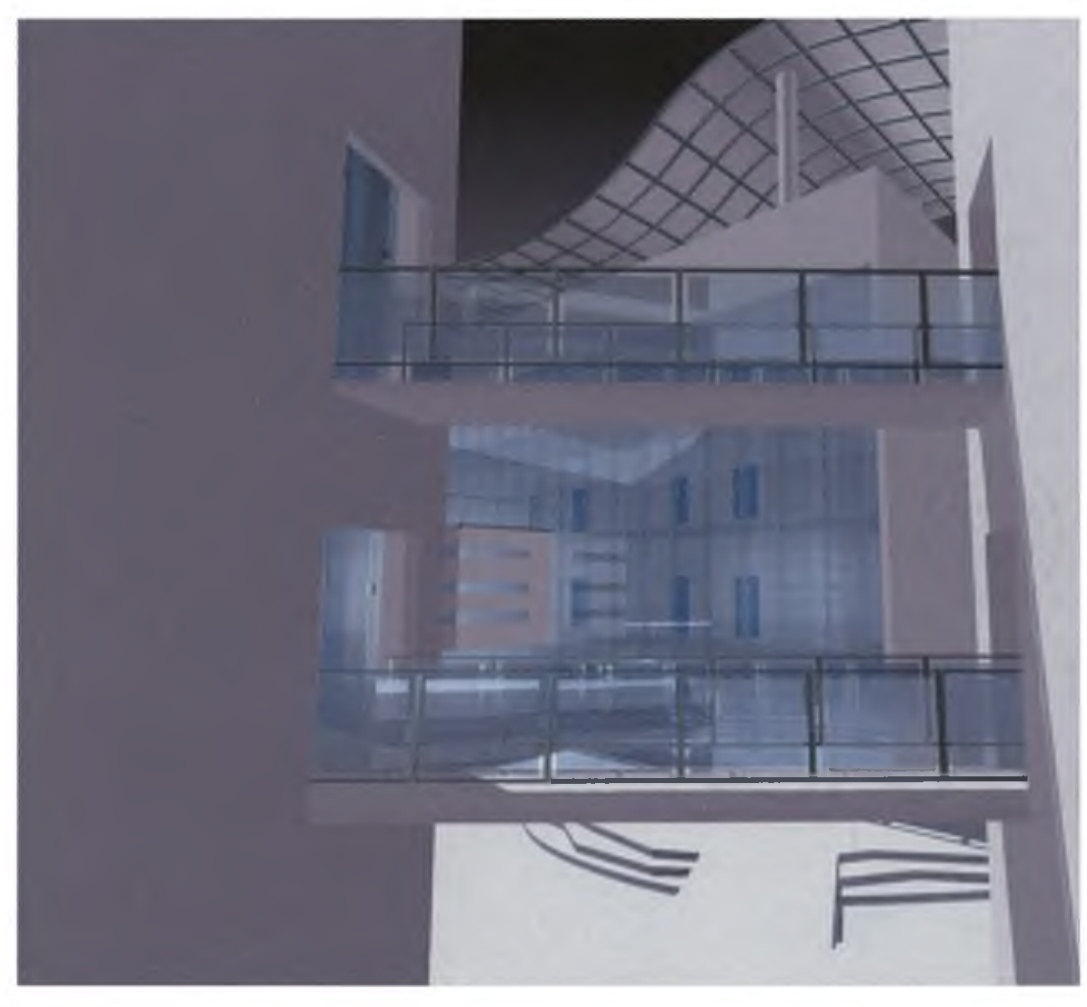

Figure

BUILDING COMPOSITION 


\section{REFERENEES}

ARrighi, Bargara A. 1997. AMERICA'S SHAME; WOMEN AND CHILDREN IN SHELTER AND THE DEGRADATION OF FAMILY ROLES. CONNECTICUT: PRAEGER PRESS.

BRUCHEY, STUART. 1998 . CHILDREN OF POVERTY: STUDIES ON THE EFFECTS OF SINGLE PARENTHOOD, THE FEMINIZATION OF POVERTY AND HOMELESS. NEW YIRK AND LONDON: GARLAND PUBLISHING INC.

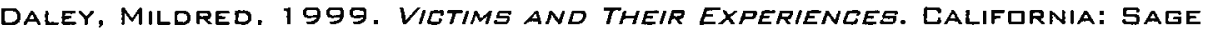
Publications.

Davis, Madeleine and Wallbridge david. 1998. Boundary and space. AN INTRODUCTION TO THE WORK OF D.W. WINNICOTT. LONDON: KARMAC BOOKS.

DODDS, GEORGE. 2DO1. BDDY AND BUILDING: ESSAYS ON GHANGING RELATION DF BODY AND AREHITECTURE. LONDON AND ENGLAND: MIT PRESS.

FERRANTE, LUCIA. 1990. HONOUR REGAINED: WOMEN IN THE CASA DI SOECLRST DI SAN PAGLO IN SIXTEENTH-CENTURY BOLOGNA. BALTIMORE: HOPKINS UNIVERSITY PRESS.

fredericson, Delora. 2001. aff olr backs. New York: gale Group inc.

gavora, Jessica. zodz. Tilting the playing field: Schodls, sports, sex AND TITLE IX. NEW YORK: ENCOUNTER BOOKS.

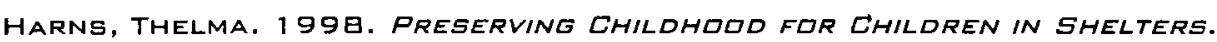
WASHINGTON, DC: CWLA PRESS.

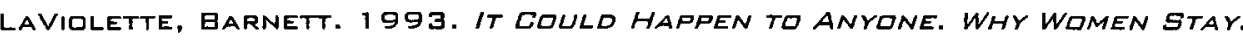
NewBURy Park, London: Sage Publications.

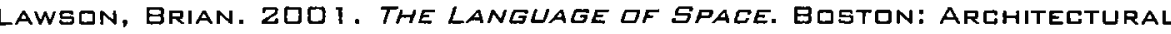
PRESS.

Liff, SHARon R. 1996. No Plage Else To Ga. Hameless Mothers and THEIR CHILDREN LIVING IN URBAN SHELTERS. NEW YORK: GARLAND PUBLISHING.

LOSEKE, DOMILEEN. 1992. THE BATTERED WOMAN AND SHELTERS. THE SOCIAL CONSTRLCTION OF WIFE ABUSE. NEW YORK: STATE UNIVERSITY OF NEW YORK PRESS.

PIMEROY, SARA B. 1995. gODDEsses, Whares, Wives aND slaves: Wamen IN CLASSICAL ANTIQUITY. NEW YORK: SHICKEN BOOKS.

RENDELL, JANE. 2QDO. GENDER SPACE ARCHITECTURE: AN INTERDISEIPLINARY INTRODUETION. LINDON AND NEW YORK: TAYLOR AND FRANGIS GRDUP PRESS. MARY Jם BIHLE AND PAUL BUULE. 1978. THE CONGISE Histary of WOMAN SLFFRAGE: SELECTIONS FROM THE CLASSIC WORK OF STANTON,
ANTHONY, GAGE, AND HARPER, ILLINOIS: UNIVERSITY OF ILLINOIS PRESS.

SHISTACK, ALEERT. 2001. SHELTERS FOR BATTERED WOMEN AND THEIR CHILDREN. SPRINGFIELD ILLINOIS: CHARLES C THOMAS PUBLISHER.

STEBNER, Eleandr J. 1997. THE WOMEN of HLLL HaLSE. NeW Yark:

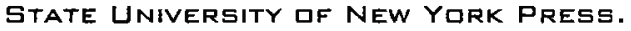

TIFFT, LARRY L. BATTERING OF WOMAN. 1993. THE FAILURE OF INTERVENTION AND THE CASE OF PREVENTION. CALIFORNIA: aXFORD PRESS.

VERDERBER, STEPHEN. 19B5. SHELTERs FDR BATTERED WOMEN AND CHILDREN: PROGRAMMING AND DESIGN ISSUES. LOUISIANA: TULANE UNIVERSITY PRESS.

WALKER, LENDRA. 1994. THE BATTERED WIMAN SYNDRDME. NEW YORK: SPRINGER PUBLISHING Co.

U.S. Dept. of Justice Bureau qf Justice statistics. zonz. "Violence against WOMEN: A NATIONAL CRIME VIETIMIZATION SURVEY REPORT".

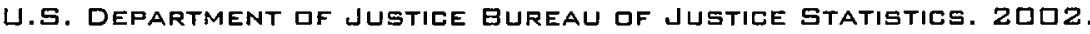
VIOLENCE GY INTIMATES. "ANALYSIG DF DATA ON CRIMES GY CURRENT IR FURMER SPQUSES, BUYFRIENDS, AND GIRLFRIENDS". 